Universidade DE SÃo PAUlO

Faculdade de Filosofia, Letras e Ciências Humanas

Departamento de Letras Clássicas e Vernáculas

Programa de Pós-Graduação em Letras Clássicas

\title{
O Brutus de Marco Túlio Cícero: estudo e tradução
}

Olavo Vinícius Barbosa de Almeida

São Paulo

2014 
Universidade de São Paulo

Faculdade de Filosofia, Letras e Ciências Humanas

Departamento de letras Clássicas e Vernáculas

Programa de Pós-Graduação em letras Clássicas

\title{
O Brutus de Marco Túlio Cícero: estudo e tradução
}

\author{
Olavo Vinícius Barbosa de Almeida
}

\begin{abstract}
DissertaÇão apresentada ao Programa de Pós-Graduação em letras Clássicas do Departamento de letras Clássicas e Vernáculas da Faculdade de Filosofia, Letras e Ciências Humanas da Universidade de São Paulo para a obtenção do título de Mestre em letras Clássicas, Sob a orientaÇão do Prof. Dr. Adriano SCATOLIN.
\end{abstract}

São Paulo

2014 


\section{Resumo}

ALMEIDA, Olavo Vinícius Barbosa de. O Brutus de Marco Túlio Cícero: estudo e tradução. 2014. 200 f. Dissertação (Mestrado). Faculdade de Filosofia, Letras e Ciências Humanas, Departamento de Letras Clássicas e Vernáculas, 2014.

Este trabalho divide-se em duas partes: a primeira consiste em um estudo sobre o diálogo Brutus de Marco Túlio Cícero, a segunda apresenta uma tradução completa da obra. Guardando características do diálogo filosófico, do relato histórico e da laudatio funebris, o Brutus pode ser resumido como uma história da oratória romana. Seguindo certa ordem cronológica, Cícero menciona e forma juízo sobre as qualidades oratórias de oradores e magistrados romanos, fazendo referência à história política de Roma, ao desenvolvimento das letras latinas, bem como a pontos de doutrina oratória. O Brutus é um diálogo (sermo) entre as personagens Bruto, Ático e o próprio Cícero. No estudo, discutem-se as características da obra enquanto diálogo, laudatio funebris, memoria e historia da oratória romana.

Palavras-Chave: Cícero, Brutus, diálogo, sermo, laudatio, laudatio funebris, memoria, monumentum, historia, historia oratorum. 


\section{Abstract}

ALMEIDA, Olavo Vinícius Barbosa de. The Brutus of Marcus Tullius Cicero: study and translation. 2014. 200 f. Dissertation (Master Degree). Faculdade de Filosofia, Letras e Ciências Humanas, Departamento de Letras Clássicas e Vernáculas, 2014.

This dissertation is divided into two parts: the first one is a study about the Brutus, a dialogue by Marcus Tullius Cicero; the second one presents its complete translation into Portuguese. The Brutus shows features of philosophic dialogue, of historical narrative and of laudatio funebris, and can be summarized as a history of Roman oratory. In chronological order, Cicero mentions and assesses the oratorical qualities of Roman orators and magistrates, while at the same time dealing with Rome's political history, with the development of Latin literature and with oratorical doctrine. The Brutus is a dialogue (sermo) between Brutus, Atticus and Cicero. This study discusses its features as a dialogue, laudatio funebris, memoria and history of Roman oratory.

Key words: Cicero, Brutus, dialogue, sermo, laudatio, laudatio funebris, memoria, monumentum, historia, historia oratorum. 
A meus avôs:

Claudionor Celestino Barbosa

Armando Ferreira Almeida

a meu tio:

José Orlando Celestino Barbosa

a minha avó per adoptionem:

Aldanizia Fernandes Seixas

In memoriam 


\section{Agradecimentos}

Ao Prof. Dr. Adriano Scatolin, pela orientação, pela amizade e pela confiança.

Ao Prof. Dr. Pablo Schwartz Frydman e à Profa. Dra. Marly de Bari Matos, que compuseram a banca de qualificação, pelos valiosíssimos comentários, questionamentos e sugestões.

Ao Prof. Dr. José Eduardo do Santos Lohner, por ter presidido o exame de qualificação e pelas suas preciosas aulas na graduação e na pós-graduação.

Ao Prof. Dr. Alexandre Pinheiro Hasegawa, pelas aulas, pelo companheirismo e pela orientação no Estágio Supervisionado.

Ao Prof. Dr. Sidney Calheiros de Lima, pelas aulas sobre Cícero.

Aos professores que fizeram parte da minha formação:

Prof. Dr. João Ângelo Oliva Neto,

Prof. Dr. Paulo Martins,

Prof. Dr. Ricardo da Cunha Lima.

Agradeço à minha companheira de todas as horas, Caroline Seixas, uxor dilectissima.

Agradeço a todos meus amigos que me acompanharam nessa jornada.

Agradeço à Coordenação de Aperfeiçoamento de Pessoal de Nível Superior (CAPES) pelo apoio financeiro, fundamental para o desenvolvimento desse trabalho. 


\section{Sumário}

$\begin{array}{ll}\text { Introdução } & 1\end{array}$

Acerca de uma "definição" do Brutus

Cícero e a polêmica com os "aticistas"

Sobre a memoria e o scriptum

Tradução

Bibliografia 


\section{Introdução}

Sem nenhuma dúvida, a capacidade oratória de Marco Túlio Cícero (106-43 a. C.) é um dos principais fatores que lhe possibilitaram alcançar notoriedade e prestígio na Roma republicana do século I a. C. Mas, além de discursos judiciários e políticos, o legado ciceroniano compreende importantes tratados de retórica e filosofia muito influentes no mundo ocidental. Na seara filosófica, muito frutificaram o De republica, o De legibus, os Academica (ainda que fragmentários), o De finibus, o De officiis, o De amicitia, o De senectute, as Tusculanae, além de textos que não chegaram até nós mas que foram conhecidos na Antiguidade: Consolatio e Hortensius, entre outros. Na cena retórica, além de compor em sua juventude uma das obras inaugurais do gênero em latim (ao menos entre as supérstites), o De inuentione, Cícero marca profundamente a teoria oratória com a publicação do De oratore, concluída no final de 55 a. C. ${ }^{1}$ Ao De oratore Cícero vincula o diálogo Brutus e o tratado Orator como um conjunto de livros que estabeleceriam a união entre a filosofia e os preceitos do discurso. ${ }^{2}$

Para a composição de muitos de seus textos, entre eles o De oratore e o Brutus, Cícero lançou mão do diálogo filosófico, gênero praticado desde a Antiguidade até o século XVIII, incluindo nomes como Platão, Aristóteles, Sêneca, Tácito, Luciano de Samósata, Santo Agostinho, Galileu, Leibniz, Hume, Diderot, entre outros. A forma dialógica adotada na composição do De oratore configura uma novidade no modo de tratamento da matéria oratória. $^{3}$ No Brutus, porém, a proposta de apresentar a história da oratória romana

\footnotetext{
${ }^{1}$ Cf. Ad Att. IV, 13, 2.

${ }^{2}$ De diuinatione, II, 4 .

${ }^{3}$ Cf. Kennedy (1972, p. 239) e NARducci (1997, p. 28).
} 
nesse gênero é ainda mais inusitada. ${ }^{4}$ Cabe lembrar que nesse diálogo, pela primeira vez em sua obra, Cícero é representado como personagem do drama. ${ }^{5}$ Tendo até então escrito e publicado os diálogos De oratore e De republica, cujas cenas e personagens remetem, respectivamente, a 91 e 129 a. C., no Brutus Cícero descreve uma conversa (sermo) em sua casa em Roma, ${ }^{6}$ em que teriam participado o próprio anfitrião e seus amigos Ático e Bruto, provavelmente entre os primeiros meses de 46 a. C., após a batalha de Tapsos. ${ }^{7}$

Esses são tempos de guerra civil. Em 49 a. C., depois de retornar da Gália, César declara guerra a Roma e adentra a cidade com suas tropas. Roma está dividida entre os partidários de César e Pompeu. Cícero se alia aos pompeianos. No entanto, depois da batalha de Farsalo, abandona Pompeu, retorna à Itália e recebe o perdão de César, que havia se tornado ditador. Cícero, então, afastado dos deveres da vida pública, cultiva o ócio e se refugia nos livros, iniciando um período de intensa produção retórico-filosófica, cujo primeiro fruto é o Brutus. A guerra civil se arrasta pela África, enquanto em Roma são esperadas notícias do conflito. São os últimos meses de 47 e os primeiros de 46 a. C.

Nesse momento, sob a ditadura de César, não há mais espaço para a contenda política nem para os certames judiciários. Trata-se de uma aguda crise institucional, cuja atmosfera é bem representada no Brutus. O diálogo, constituído de um breve prólogo da persona auctoris seguido da conversa entre as personagens, desenvolve os temas da morte e da dor fazendo um elogio ao orador e político Hortênsio, morto em 50 a. C., o que fez com que muitos estudiosos o lessem como uma laudatio funebris. ${ }^{8}$ No prólogo, Cícero considera a morte de Hortênsio bem-aventurada pelo fato de o orador não ter visto a atual situação da República e o deserto dos tribunais e das assembleias, referência evidente

\footnotetext{
${ }^{4}$ Cf. Douglas (1966, p. xxii).

${ }^{5}$ Note-se que, embora Cícero apareça como personagem no De legibus, esse diálogo permaneceu incompleto, não sendo mencionado por ele no 'catálogo' que faz do conjunto da sua própria obra, em $D e$ diuinatione II, 4. Além disso, em Brutus 19, a personagem Ático afirma que Cícero não publicara nada depois do De republica.

${ }^{6}$ Cf. NARDUCCI (1997, p. 104).

${ }^{7}$ Sobre a data dramática do Brutus, Gowing (2000, p. 64) sugere: "the dramatic date of the Brutus may therefore be assigned to the period immediately after news of the battle [of Thapsus] and events of the following few days has reached Rome" (Itálico do original). Cf. Douglas (1966, pp. ix-x), e NARDUCCI (1997 p. 104).

${ }^{8}$ Cf. Gowing (2000, p. 58), Narducci (1997, p. 6), Dugan (2005, p. 195), Marchese (2011, p. 41).
} 
aos acontecimentos políticos que perturbam a república romana. ${ }^{9}$ Na primeira cena, Cícero recebe em sua casa a visita de seus amigos Ático e Bruto e, na primeira fala das personagens, lhes faz a seguinte pergunta: "e então, finalmente alguma notícia?" (numquid tandem noui [Brutus 10]). Ático logo estabelece o silêncio sobre política (de re publica esset silentium [Brutus 11]) e diz que prefere ouvi-lo. Ele, então, solicita a Cícero que relate a Bruto certa conversa que ambos teriam tido recentemente em Túsculo a respeito dos oradores: quando surgiram, quem foram eles e que valor possuíam como oradores, ${ }^{10}$ eis a razão da visita e da conversa. A partir da fala de Ático, o que se propõe é uma conversa a respeito da história da oratória romana na figura de seus oradores. A resposta de Cícero é positiva, mas contém uma ressalva, si potuero, faciam (Brutus 21). O resultado disso é um diálogo multifacetado, inusitado, ${ }^{11}$ uma obra de difícil categorização, conforme aponta GOWING (2000, p. 39):

"In a literature as genre-bound and precedent-driven as Roman literature, Cicero's Brutus is an anomaly. While exhibiting characteristics of a philosophical treatise, a dialogue, a rhetorical handbook, an historical narrative, biography, and even a speech (especially a laudatio funebris), this account of Roman orators and oratory set in the immediate aftermath of Caesar's victory at Thapsus on April 6, 46 BC resists firm categorization."

O Brutus é a primeira obra do segundo período da produção retórico-filosófica de Cícero, resultante do ócio a que é forçado sob o domínio de César, que consolidava seu poder com a vitória sobre as tropas pompeianas. Em tais condições, resta a Cícero, quer

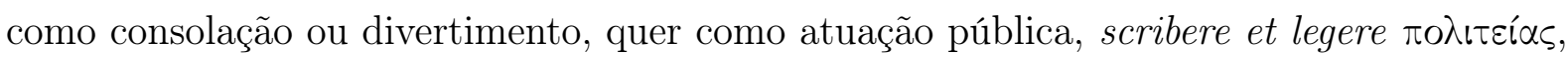
substituindo a cúria e o fórum pelas litterae e pelos libri, conforme escreve a Varrão em carta de abril de 46 a. C., cuja datação é muito próxima à da escrita do Brutus:

\footnotetext{
${ }^{9}$ Fox (2007, p. 179): "The pain that Cicero himself feels in these changed circumstances is precisely the one which Hortensius was spared, that of seeing rhetoric silenced and the power of the orator to control public affairs eclipsed by that of military power (arma)".

${ }^{10}$ Brutus 20.

${ }^{11}$ Douglas (1966, p. xxiii): "Cicero's undertaking, was, then, unusual, perhaps completely novel, a fact which adds much to the interest of attempting to assess the formal merits of his work".
} 
Sed haec tu melius; modo nobis stet illud, una uiuere in studiis nostris, a quibus antea delectationem modo petebamus, nunc uero etiam salutem; non deesse, si qui adhibere uolet, non modo ut architectos uerum etiam ut fabros ad aedificandam rem publicam, et potius libenter accurrere; si nemo utetur

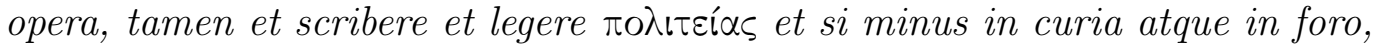
at in litteris et in libris, ut doctissimi ueteres fecerunt, nauare rem publicam et de moribus ac legibus quaerere. ${ }^{12}$ (Ad fam., IX, 2, 4)

Guardando características do diálogo filosófico, do relato histórico, bem como da laudatio funebris ${ }^{13}$ o Brutus pode ser resumido como uma história da oratória romana em que Cícero, seguindo uma ordem cronológica, menciona e forma juízo acerca das qualidades oratórias de mais de duzentos oradores e magistrados romanos ${ }^{14}$ fazendo referência à história política de Roma, ao desenvolvimento das letras latinas e a pontos de doutrina oratória. $^{15}$

Nesta dissertação apresentaremos um estudo introdutório e proporemos uma tradução completa do diálogo Brutus de Marco Túlio Cícero. Nosso estudo constará de três capítulos. No primeiro, trata-se de discutir em que medida o Brutus guarda características do diálogo filosófico, da laudatio funebris, do relato histórico e da autobiografia, procurando em alguma medida uma "definição" da obra. No segundo, trataremos da polêmica de Cícero com os chamados aticistas. No último, discutiremos a questão do Brutus enquanto texto escrito: por um lado, sua função como monumentum e memoria para a posteridade, e, por outro lado, a escrita como dimensão privada da eloquentia, na medida em que Cícero personifica a eloquentia como uma adulta virgo, que com o deserto dos tribunais e assembleias deveria ser preservada no espaço da casa (domus).

\footnotetext{
${ }^{12} \mathrm{~A}$ referência de Cícero a de moribus ac legibus quaerere pode sugerir a retomada da escrita do $D e$ legibus. Cf. Gowing (2000, p. 40) e Hendrickson (1926, p. 250). No entanto, o fato é que depois da mencionada carta a primeira obra "publicada" é o Brutus.

${ }^{13}$ Dugan (2005, p. 173): "Onto these two basic generic codes of the Brutus (literary history and philosophical dialogue) Cicero grafts a third: the Roman aristocratic funeral oration".

${ }^{14}$ Sumner (1973, p. 3).

${ }^{15}$ Brutus 319: "toda esta nossa conversa requer não apenas uma enumeração de oradores, mas também certos preceitos" (omnis hic sermo noster non solum enumerationem oratoriam uerum etiam praecepta quaedam desiderat)".
} 


\section{Acerca de uma "definição" do Brutus}

Neste primeiro capítulo pretendemos discutir em que medida o Brutus contém características do diálogo filosófico, da laudatio funebris, do relato histórico (historia) e da autobiografia. Primeiro, faremos um breve levantamento sobre os principais aspectos do gênero dialógico em Cícero. Num segundo momento, analisaremos o prólogo dedicado a Hortênsio e a laudatio funebris. Em seguida, observaremos o diálogo sob a perspectiva da historia romanorum oratorum e sua relação com a obra de Ático, o liber annalis. Finalmente, analisaremos a questão da autobiografia no Brutus.

\section{Os diálogos ciceronianos}

Autor de discursos, Cícero se aventura na escrita de diálogos. Em algumas de suas cartas, ele nos revela suas reflexões acerca de sua composição. Em carta a Varrão, por exemplo, há referência a certo mos dialogorum. ${ }^{16}$ Nessa carta, Cícero relata a Varrão que compôs um diálogo (sermo) representando a si mesmo, Varrão e Ático como personagens, discutindo a filosofia acadêmica, atribuindo a exposição da doutrina de Antíoco à personagem Varrão e a exposição da doutrina de Fílon à personagem Cícero. A referência ao mos dialogorum surge como justificativa para a representação de uma conversa entre eles que jamais existiu. ${ }^{17}$ Falando sobre o De oratore e o De republica em carta a seu irmão Quinto, Cícero se mostra sensível às críticas que teria recebido com relação à escrita do De republica,

\footnotetext{
${ }^{16}$ Ad fam. IX, 8, 1.

${ }^{17}$ Ad fam. IX, 8, 1: puto fore ut, cum legeris, mirere nos id locutos esse inter nos, quod numquam locuti sumus [penso que quando você ler vai se admirar de nos ver conversando sobre algo de que nunca conversamos].
} 
segundo as quais o texto conteria mais auctoritas se as discussões fossem conduzidas pelo próprio Cícero como personagem. ${ }^{18}$ São muitas as questões relativas aos critérios de composição dos diálogos ciceronianos. Para este trabalho, interessa-nos particularmente determo-nos em alguns aspectos mais genéricos, como por exemplo, a técnica de citação neles utilizada.

Hendrickson demonstrou que os diálogos ciceronianos mantêm uma antiga tradição de escritos segundo a qual, ao se fazer referência a eventos históricos, textos filosóficos ou literários, geralmente não se recorre à "citação" de livros ou outros textos escritos, mas as ideias são apresentadas como tendo sido reportadas por algum modo de expressão de oralidade. ${ }^{19}$ Seria um exemplo disso a referência a um episódio histórico que Cícero faz tanto no Brutus (85) como no De oratore (I, 227), provavelmente com base num escrito de Públio Rutílio Rufo, Libri de vita sua. ${ }^{20}$ No Brutus, esse episódio teria sido transmitido oralmente a Cícero pelo próprio Rutílio Rufo (memoria teneo Smyrnae me ex P. Rutilio Rufo audisse 85). Evidentemente, não se abandona a menção direta a textos escritos; pelo contrário, o Brutus é permeado de referências a documentos escritos, que desempenham papel importantíssimo no diálogo.

\section{Veri similis e decorum}

Na base dos procedimentos compositivos dos diálogos ciceronianos estão as noções de verossimilhança (veri similis) e decoro (decorum, decus, quid decet). A verossimilhança, em retórica, é uma qualidade da narratio. ${ }^{21}$ A narratio deve ser verossímil, quer dizer, o

\footnotetext{
${ }^{18} \mathrm{Ad}$ Q. fr. III, 5,1 .

${ }^{19}$ Hendrickson (1906, p. 184): "The Ciceronian dialogue, reminiscent of the origins of this literary form in a metropolis of talkers, and at a time before the general diffusion of books, still aims to maintain the fiction that spoken discourse is the normal medium for the communication and transmission of thought (...) Again, within the dialogue itself references to historical events and to literature of an earlier time are made usually by appeal not to books or to historical records, but to the evidence of report, either vaguely and in general terms - accepimus, video, audivi, etc., or with specific designation of some medium of oral communication".

${ }^{20}$ HENDRICKSON (1906, p. 194): "The likelihood that the story is drawn from a written record is of course greatly enhanced by the fact that we can refer it to so natural a source as the famous memoirs of Rutilius, the Libri de vita sua."

${ }^{21}$ Rhetorica ad Herenium I, 14; De inuentione I, 29; De oratore II, 83; Partitiones oratoriae 34.
} 
relato deve ser possível ou provável, sem parecer contrariar a verdade. ${ }^{22}$ Cícero, no prólogo do De oratore (I, 26), diz relatar as discussões que teriam ocorrido em 91 a. C. na quinta de Lúcio Licínio Crasso e que lhe teriam sido reportadas por Caio Aurélio Cota, que teria presenciado e participado da conversa no feriado dos jogos latinos daquele ano. Do mesmo modo, no De republica (I, 13), as discussões desse diálogo teriam sido reportadas a Cícero por Públio Rutílio Rufo, com quem ele teria tido contato quando de sua viagem a Esmirna, forjando-se o verossímil de que as conversas narradas pela persona auctoris em ambos os diálogos lhe teriam sido reportadas por pessoas que teriam presenciado e acompanhado as "verdadeiras conversas". ${ }^{23}$ Mas é justamente no sentido da crítica à falta de verossimilhança que, em carta a seu irmão Quinto ( $A d$ Q. fr. III, 5), Cícero comenta a repreensão de certo Salústio pelo fato de ele não ter falado em própria pessoa no $D e$ republica e ter situado a discussão numa época muito distante (129 a. C.), falando de pessoas que não conhecera pessoalmente, tornando a obra tanto mais inverossímil quanto menos persuasiva. A verossimilhança se refere à adequação das circunstâncias, bem como à coerência histórica dos eventos mencionados e biográfica das personagens representadas nos diálogos. ${ }^{24}$

Em Cícero, o decorum é uma noção que opera tanto no âmbito da retórica e da poética como no da ética. O decorum se define como aquilo que é conveniente tanto na ação humana como na escrita oratória e poética, traduzindo a noção grega de $\pi p \varepsilon ́ \pi o v .{ }^{25}$ Nos diálogos ciceronianos, a noção de decorum se aplica tanto à caracterização das personagens dos diálogos como à caracterização da própria persona auctoris. Lembremos o fato de

\footnotetext{
${ }^{22} \mathrm{~A}$ noção de verossimilhança, entre os latinos, se aproxima da noção aristotélica de sixós, presente na Retórica (1357 a 35) e na Poética (1454 a 35).

${ }^{23}$ Hendrickson (1906, p. 184): "Thus Rutilius Rufus in the De re publica is the connecting link between the Scipionic group and Cicero, while Cotta and Scaevola play a similar rôle for the De oratore and the Laelius respectively. Instances of frank invention like the Cato Major, with no suggestion of a connecting intermediary between the original conversation and the author, lose an element of dramatic persuasiveness which renders them less artistic."

${ }^{24}$ LeVine (1958, p. 148): "[...] I have indicated three important considerations that guided Cicero in the composition of his dialogues: appropriateness of circumstances, eminence of the principal interlocutors and historical or biographical verisimilitude".

${ }^{25}$ Orator 70: [Pois, tal como na vida, também no discurso nada é mais difícil de perceber do que aquilo que convém. A isso os gregos chamam rpérov, nós bem podemos chamá-lo decoro.] ut enim in uita sic in oratione nihil est difficilius quam quid deceat uidere. Пре́rov appelant hoc Graeci, nos dicamus sane decorum.
} 
Cícero ter retirado das discussões do segundo e terceiro livros do De oratore a personagem Cévola, nos livros em que as discussões eram mais técnicas, alegando falta de decoro. ${ }^{26}$ Diz respeito ao decoro (quid decet) também o fato de as discussões, tanto nos livros sobre o orador como nos que tratam do homem e da coisa pública, ocorrerem em dias feriados, uma vez que seria impróprio e inadequado que eminentes políticos romanos se enveredassem em discussões sobre teorias retóricas e políticas muito comuns entre eruditos gregos mas alheias ao costume romano da época, a não ser em dias de ócio e depois de cumpridas as obrigações das funções públicas. ${ }^{27}$ No caso do Brutus, o estado de guerra civil possibilita o ócio para a conversa entre os amigos. Não se fala sobre política abertamente, mas se fala de oradores que haviam sido personagens importantes da história política da república romana.

\section{Platão, Aristóteles e os diálogos ciceronianos}

Platão e Aristóteles são as autoridades do gênero dialógico reivindicadas por Cícero como principais modelos para seus diálogos. No De oratore, Cícero faz alusão ao Fedro de Platão. ${ }^{28}$ Ao mencionar o mais famoso discípulo de Sócrates, Cícero sutilmente também acena para o caráter fictício dos diálogos quando diz que o discurso de Platão é que fez crescer o plátano que oferece a sombra para que as personagens Sócrates e Fedro se acomodem e continuem a conversa que iniciaram. No Brutus, as personagens se sentam para conversar junto a uma estátua de Platão. ${ }^{29}$ Para Quintiliano, Cícero é o principal rival do filósofo ateniense entre os latinos, Platonis aemulus. ${ }^{30}$ Segundo o próprio Cícero,

\footnotetext{
${ }^{26}$ Ad. Att. IV 16, 3 .

${ }^{27}$ Levine $(1958,147)$ : "Thus, in his representation of the mise en scène, Cicero often exercised special care to indicate that the discussions of which he gave an account occurred under circumstances which did not interfere with the fulfillment of public duties and obligations by the participating speakers".

${ }^{28}$ NARduCCI (1997, p. 29) "Una chiara allusione al Fedro è costituita, all'inizio del dialogo [ $s c . D e$ oratore], della menzione del platano sotto il quale gli interlocutori si siedono per tenere il loro primo dibattito (I 28); e sotto la suggestione dell'accenno all'astro sorgente di Isocrate col quale il Fedro si conclude, i personaggi ciceroniani pongono termine alla loro conversazione preconizzando, per l'ancor giovane Ortensio, un avvenire di grandissimo oratore (III 228 sg.)".

${ }^{29}$ Brut. 24.

${ }^{30}$ Inst. orat. X 1, 123.
} 
é seguindo Aristóteles que ele faz uso do prólogo pessoal em seus diálogos. ${ }^{31}$ Em célebre carta a Lêntulo Spinter (Ad fam. I, 9, 23), Cícero relata que compôs seu diálogo sobre o orador segundo o Aristotelio more, ${ }^{32}$ que provavelmente se refere ao procedimento acadêmico-peripatético da disputatio in utramque partem.

É possível depreender de algumas de suas cartas que ele também imitava Heráclides do Ponto, ${ }^{33}$ filósofo peripatético que, segundo Diógenes Laércio, escreveu diálogos e imitava Platão. $^{34}$ No De republica, ainda que não sejam esquecidos Panécio e Políbio como principais autores do ponto de vista da doutrina filosófica, ${ }^{35}$ mais uma vez Platão é evocado como modelo para o texto de Cícero. ${ }^{36}$

Entre as obras desses filósofos, o Fedro de Platão e a Retórica de Aristóteles ecoam no De oratore, ao passo que a República de Platão e provavelmente o Político ${ }^{37}$ de Aristóteles estão presentes de alguma forma na reflexão ciceroniana do De republica, ${ }^{38}$ sem falar do inacabado diálogo platônico denominado Leis, que ecoa no também inacabado De legibus ${ }^{39}$ de Cícero. Em suma, embora não se desconsidere a recepção e transmissão desses autores entre as filosofias helenísticas, parece claro o procedimento de tentar se vincular a essa tradição acadêmico-peripatética, como na formulação do próprio Cícero no segundo livro do De divinatione. ${ }^{40}$

\footnotetext{
${ }^{31}$ Ad Att. IV 16, 2.

${ }^{32}$ Ad fam. I 9, 23.

${ }^{33}$ Ad Att. XIII 19, 4, e Ad Q. fr. III 5, 1.

${ }^{34}$ Vidas dos filósofos $\mathrm{V}, 86$.

${ }^{35}$ De rep. I, 34, 10; II, 27, 12; IV, 3, 7 (Políbio); I, 15, 8; I, 34, 10 (Panécio).

${ }^{36}$ De republica II, 3: facilius autem quod est propositum consequar, si nostram rem publicam vobis et nascentem et crescentem et adultam et iam firmam atque robustam ostendero. quam si mihi aliquam, ut apud Platonem Socrates, ipse finxero. ["Mais facilmente, porém, eu satisfarei o nosso propósito se vos mostrar o nosso Estado a nascer, a crescer, adulto e já firme e robusto, do que se criar para mim, como Sócrates em Platão". ] (Tradução de Francisco de Oliveira).

${ }^{37} \mathrm{Em}$ Ad Q. Fr. III, 5, 1, há menção a certa obra de Aristóteles cujo conteúdo é a melhor constituição e o melhor cidadão (de optimo statu ciuitatis et de optimo uiro). Cf. BOYANCÉ (1941, p. 177): "Il s'agit, selon toute vraisemblance, pour Aristote non de la Politique [...], mais [...] du Politique, ouvrage perdu de la période platonicienne".

${ }^{38}$ Nesse caso, observa-se a doutrina estoica de Panécio e a reflexão histórica de Políbio, em vez da disciplina platônica.

${ }^{39}$ Mais uma vez, a doutrina estoica de Panécio predomina sobre a acadêmico-peripatética. Cf. VALENTE (1984, p. 466).

${ }^{40}$ De divinatione II, 3-4: Atque his libris adnumerandi sunt sex de re publica, quos tum scripsimus, cum gubernacula rei publicae tenebamus: magnus locus philosophiaeque proprius a Platone, Aristotele, Theophrasto totaque Peripateticorum familia tractatus uberrime (...) Cumque Aristoteles itemque Theophrastus, excellentes viri cum subtilitate tum copia, cum philosophia dicendi etiam praecepta coniunxerint,
} 
No que concerne ao Brutus, ainda que possamos falar em procedimentos imitativos com relação a Platão e Aristóteles, não dispomos de obras desses autores gregos que possam ter servido de "modelo" para esse diálogo ciceroniano, embora Douglas faça referência a

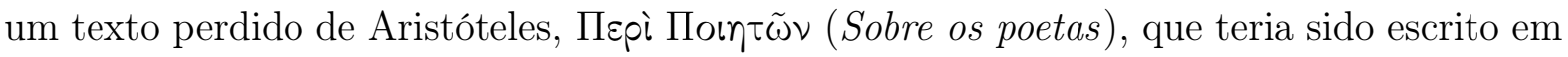
forma de diálogo. ${ }^{41}$ Contudo, não se pode esquecer da ironia atribuída a Cícero pelo seu amigo Ático, que diz ser uma característica de Sócrates, presente nos livros de Xenofonte e Ésquines, mas sobretudo em Platão. ${ }^{42}$ Além disso, Cícero havia concluído a dramatização do De oratore por meio de uma alusão à personagem do jovem Hortênsio como uma promessa na oratória romana, tal como no Fedro platônico, no qual a figura do jovem Isócrates despontava como a possível realização de uma retórica filosófica, estabelecendo, assim, o Brutus como continuidade daquele, ${ }^{43}$ na medida em que neste é preponderante a figura do consagrado orador Hortênsio, bem como é retomada a imagem de Platão na breve descrição cenográfica da quinta de Cícero onde se dá a conversa, em cujo jardim as personagens se acomodam próximo a uma estátua do filósofo grego. Quanto à presença de Aristóteles no diálogo ciceroniano, parece residir nos aspectos formais da obra, a saber, além do prólogo, o caráter predominantemente expositivo da personagem principal, nesse caso o próprio Cícero. ${ }^{44}$

No entanto, não seria suficiente dizer que Cícero procura imitar Platão e Aristóteles.

nostri quoque oratorii libri in eundem librorum numerum referendi videntur: ita tres erunt de oratore, quartus Brutus, quintus Orator. [ "E devem ser colocados entre esses livros aqueles seis sobre a república, que escrevemos quando detínhamos o leme da república: tema importante e próprio da filosofia, tratado de modo abundante por Platão, Aristóteles, Teofrasto e toda a escola dos peripatéticos (...). E como Aristóteles e, igualmente, Teofrasto, varões excelentes tanto pelo refinamento como pela copiosidade, uniram à filosofia também os preceitos do discurso, creio que também nossos livros de oratória devem ser inseridos nessa mesma categoria de livros: assim, seriam três sobre o orador, o quarto, Brutus, o quinto, Orator".].

${ }^{41}$ Cf. Douglas (1966, p. xxiii).

${ }^{42}$ Brutus 292.

${ }^{43}$ MARChESE (2011, pp. 11-12): "Certamente Ortensio rappresenta il ponte simbolico tra le due opere, non fosse altro perchè nel de oratore è colto nel momento in cui fa il suo trionfale ingresso nella carriera forense e politica, mentre l'apertura del Brutus segnala drammaticamente il vuoto lasciato dalla sua scomparsa: non c'è modo più efficace, per rappresentare il cambiamento disposto dal trascorrere del tempo, del ricorso all'arco dell'esistenza di un uomo".

${ }^{44}$ NARDUCCI, (1997, p. 104) "Per l'andamento generale il Brutus si avvicina tuttavia più al dialogo di matrice aristotelica che a quello di matrice platonica: come altrove, a un confronto serrato e incalzante Cicerone preferisce una forma di esposizione praticamente continua, dove la trattazione svolta dal personaggio principale (in questo caso, lui stesso) solo di quando in quando è interrota da brevi interventi dei suoi interlocutori." 
Além dos modelos gregos explícitos e implícitos, Cícero acrescenta ao gênero dialógico a auctoritas e o nomen romanos. À diferença dos filósofos gregos, Cícero ocupou funções políticas importantes na república e escreveu a maior parte de sua obra nos momentos de crise em Roma. Após o exílio, quando a república estava dominada por César e Pompeu, Cícero concluiu a escrita do De oratore em 55 a. C.. Em 46 a. C., ele escreve o Brutus, enquanto César vencia Pompeu na guerra civil. Podemos dizer que a auctoris persona que Cícero constrói em seus diálogos é a do político que, afastado do munus senatorium pela crise da república, encontra seu porto seguro nos studia litterarum. Nos textos posteriores a 46 a.C., quando o domínio de César já havia se consolidado, Cícero apresenta sua obra como um munus reipublicae. ${ }^{45}$ De um lado, a adoção de uma persona vinculada à ordem senatorial, de outro, a tentativa de obter prestígio pelas letras, retórica e filosofia, retomando a tradição de autores latinos como Ênio. ${ }^{46}$ É com bastante liberdade que Cícero imita modelos gregos e os reinventa segundo as tradições e instituições romanas. Como afirma Auvray-Assayas ao analisar o diálogo ciceroniano, trata-se de "imitação livre" e "criação autônoma". ${ }^{47}$ Numa de suas cartas a Ático, Cícero chega a afirmar que seus diálogos Academici não encontram obra semelhante entre os gregos. ${ }^{48}$

\section{Sobre o prólogo do Brutus}

É possível dizer que o prólogo do Brutus se divide em duas partes. Na primeira, há uma homenagem a um dos principais rivais de Cícero na oratória, Quinto Hortênsio Hórtalo, morto em 50 a. C. (1-9); na segunda parte, as personagens do diálogo, a saber, o próprio Cícero e seus amigos Ático e Bruto, encenam a ocasião e o início da conversa (10-24). A

\footnotetext{
${ }^{45}$ Cf. Tusc. I, 1; De diuin. I, 4; Acad. Post. III; De finibus I, 10.

${ }^{46}$ De finibus I, 7.

${ }^{47}$ Auvray-Assayas (2001, pp. 241-242): "Imitation libre, mélange d'emprunts, sélection des passages, le manifeste littéraire grâce auquel se définit l'autonomie des poètes latins est celui que Cicéron met en avant pour fixer les cadres de son travail: l'écriture du dialogue s'élabore dans le champ de la littérature, elle jouit des mêmes libertés (...) Cicéron se définit bien comme un 'fondateur', en calquant sa démarche sur celles des premiers à écrire la littérature latine. Cela signifie clairement qu'écrire des dialogues philosophiques n'est pas tant pour lui un acte de reproduction qu'un acte de créaction."

${ }^{48} \mathrm{Ad}$ Att. XIII 13, 1.
} 
primeira parte, o prólogo propriamente dito, se assemelha a um discurso; a segunda, como que um exórdio dialógico, guarda características do drama.

\section{Hortênsio e a laudatio funebris}

Embora intitulado Brutus, o diálogo se inicia com uma homenagem a Hortênsio (114-50 a. C.), que havia sido rival de Cícero em vários processos, o mais célebre dos quais contra Verres. Ao escrever o De oratore em 55 a. C., Cícero já prestara homenagem ao engenho, arte e memória desse orador, fazendo ao final do terceiro livro (III, 228-230) um elogio ao jovem Hortênsio. ${ }^{49}$ Oito anos mais velho do que Cícero, Hortênsio também reconheceu o talento do rival quando cooptou e inaugurou Cícero no colégio dos áugures, em 53 a. C. ${ }^{50}$ Estabelece-se com isso um forte vínculo entre ambos, na forma da amicitia em seu sentido político, expressa pelos termos socius e consors, opostos a adversarius e obtrectator. ${ }^{51} \mathrm{Em}$ chave imitativo-emulativa, Hortênsio desempenha um papel fundamental no Brutus, tal como Crasso no De oratore, sendo figura importantíssima no prólogo e, por assim dizer, no epílogo do diálogo. O elogio a Hortênsio é também dirigido, obliquamente, àquele que posteriormente o teria superado, o próprio Cícero. ${ }^{52}$

A primeira frase do prólogo menciona a ocasião em que Cícero teria tomado conhecimento da morte de Hortênsio: cum e Cilicia decedens Rhodum venissem et eo mihi de Q. Hortensi morte esse adlatum, opinione omnium maiorem animo cepi dolorem ("Quando, de retorno da província da Cilícia, eu cheguei a Rodes e lá fui informado da morte de

\footnotetext{
${ }^{49}$ Embora esse elogio possa ser entendido como irônico, a exemplo do que acontece com o elogio a Isócrates no final do Fedro de Platão.

${ }^{50}$ Douglas (1966, p. 2).

${ }^{51}$ Brutus 2.

${ }^{52}$ Brutus 317: Duo tum excellebant oratores qui me imitando cupiditate incitarent, Cotta et Hortensius[...]itaque cum Hortensio mihi magis arbitrabar rem esse, quod et dicendi ardore eram proprior et aetate coniunctior ["Os dois melhores oradores do momento, que me incitavam o desejo de imitá-los, eram Cota e Hortênsio, (...) Por isso, parecia-me que a disputa se dava sobretudo com Hortênsio, porque a mim mais se adequava seu ímpeto oratório e a proximidade da idade".]. LowRIE (2008, p. 133) observa que "elite men competed for honor and uirtus within certain canons of style, which means that they both imitated one another and granted each other recognition. This competition made them who they were and defined them in comparison to others". Nas palavras de Dugan (2005, pp. 199-200), "Cicero thus presents his relationship with Hortensius as one of mutual benefit: the rivalry between them spurred each to greater attainments than they would have otherwise achieved. Aemulatio and imitatio thus shape both the development of oratory as a whole and the formation of individual orators".
} 
Quinto Hortênsio, senti uma dor maior do que todos poderiam imaginar."). O termo técnico decedens ${ }^{53}$ usado para indicar o término da administração de uma província (Cícero havia sido procônsul na Cilícia entre 51 e 50 a. C.), já denota o vínculo do autor com o poder político de Roma. O texto segue em tom de lamento (dolebam), evocando a lembrança de Hortênsio num paralelismo que, por um lado, remete à perda de um amigo (amico amisso), o que diz respeito ao âmbito pessoal (me privatum videbam), e, por outro lado, remete à morte de um áugure (interitu talis auguris), o que configura uma perda no âmbito público (dignitatem nostri conlegi deminutam). ${ }^{54}$ A sequência do texto acentua o caráter político da perda de um cidadão como Hortênsio (magna sapientium civium bonorumque penuria) em um momento tão delicado para a república (alienissimo rei publicae tempore). A rivalidade entre ambos não os fez inimigos e detratores um do outro, mas sim aliados e colegas. Assim, Cícero presta essa homenagem fúnebre a Hortênsio tal como uma tradição de nobres poetas que manifestam seu sofrimento pela morte de seus iguais. ${ }^{55}$ A morte de Hortênsio é também para Cícero a diminuição da sua própria glória (cum quo certare erat gloriosius quam omnino adversarium non habere 3 ). ${ }^{56}$

Em seguida, Cícero compara a sorte de Hortênsio com a dos cidadãos que estão vivos. A morte desse orador fora como que o coroamento de uma vida bem-afortunada, se comparada à sorte de seus concidadãos, que vivem um momento em que não é possível salvar a república, pois já não se pode mais atuar politicamente, mas apenas lamentar sua triste situação (cum lugere facilius rem publicam posset, si viveret, quam iuvare 4). Trata-se de um locus do elogio, a saber, ressaltar a boa fortuna do homenageado. ${ }^{57}$ Os termos usados por Cícero nas primeiras seções do prólogo circulam num campo semântico

\footnotetext{
${ }^{53}$ Douglas $(1966$, p. 1).

${ }^{54}$ MARChESE (2011, p. 19): "Secondo le nostre categorie, certo molto lontane dall'esperienza di chi quel passo ha scritto, questo vuol dire che da un lato sta il risentimento privato e personale, dall'altro quello pubblico e istituzionale".

${ }^{55}$ Douglas (1966, p. 3): "as Sophocles at the death of Euripides (vit. Eur. 10)". ERCOLE (1891, p. 4): "L'antichità ricorda altri simili fati, ma pare che Cicerone abbia qui in mente ciò che di Sofocle si narra (Vita Eurip., 10), che cioè vestisse a bruno all'anunzio della morte d'Eurip.".

${ }^{56}$ MARChese (2011, p. 19): "Perchè la morte di Ortensio, oltre a privarlo del conforto di un amico carissimo, rappresenta un duro colpo per l'identità personale di Cicerone, dal momento che si configura come la perdita di una parte cospicua di sé".

${ }^{57} \mathrm{O}$ mesmo argumento está presente no De oratore III, 8, quando Cícero fala da morte de Crasso como bem-aventurada por não ter visto a desolação da guerra civil
} 
claramente fúnebre e lamentoso (morte, dolorem, interitu, dolebam [1], molestiam, triste, dolebamque, amiseram [2], morte doluisse, interitum [3], ille cessit e vita, occidit, lugere, incommodo, detrimentoque, doleamus. misericordia [4], dolemus, angimur [5]). A morte de Hortênsio coincidiria com a morte da eloquência romana, de modo que o Brutus pode ser lido como uma laudatio funebris da oratória romana. ${ }^{58}$

Estabelece-se, por assim dizer, um paralelo entre vida e morte, em que o legado dos oradores mortos desempenha um papel preponderante no relato ciceroniano da história da oratória romana. ${ }^{59} \mathrm{Na}$ ficção do diálogo, embora haja algumas excessões, Cícero afirma que irá comentar somente a oratória daqueles que já morreram. Assim, o Brutus se apresenta como uma grande laudatio funebris em que Cícero traça os retratos de centenas de oradores que viveram e atuaram no fórum e na cúria romana.

O retrato oratório de diversos personagens da história política de Roma esboçado por Cícero no Brutus nos remete à ideia daquela famosa descrição do cerimonial fúnebre da aristocracia romana relatada por Políbio (História VI, 53-4). Políbio nos conta que, nos dias de festas religiosas públicas e por ocasião da morte de algum importante membro das famílias aristocráticas, máscaras mortuárias, que reproduziam com fidelidade a tez e a feição dos antepassados, eram conduzidas por homens que se assemelhavam em estatura e compleição a cada um dos defuntos. Alguns deles vestiam uma toga com debrum, se o defunto tivesse sido cônsul ou pretor, outros vestiam uma toga toda de púrpura, se o defunto tivesse sido censor, outros, enfim, eram apresentados com uma toga bordada de ouro, se o defunto tivesse recebido as honras do triunfo. Esses homens eram levados até os Rostros, onde se sentavam nas cadeiras de marfim. Políbio caracteriza o evento como um espetáculo cívico e nobilitante, uma importante instituição que não apenas

\footnotetext{
${ }^{58}$ NARDUCCI (1997, p. 98) afirma que "Giustamente si è parlato del Brutus come di una Grabrede, di un epitafio dell'eloquenza romana; il tono funereo è presente fino dal proemio, una lunga felicitazione per la tempestiva morte che ha impedito a Ortensio - uno dei principali oratori contemporanei di Cicerone di assistere alle sconvolgenti vicende della guerra civile e della decomposizione della res publica".

${ }^{59}$ Fox (2007, p. 179): "Death, or grief at that death, is in fact a springboard for Cicero to deliberate upon a number of key themes: most obviously, that of the dead orator. Almost all the orators who come to be discussed in the following dialogue are dead, but the notion of the dead orator has much wider, almost symbolic ramifications. The death of Hortensius prompts a meditation on the question of the effect of the dead upon the living, and upon the question of the legacy of individuals".
} 
servia para a educação da jovem aristocracia romana, mas que também tinha o intuito de imortalizar a fama de homens ilustres. Além disso, era pronunciado um discurso sobre os feitos do defunto e de seus antepassados. É justamente esse discurso que a tradição romana chamava de laudatio funebris. ${ }^{60}$ Nesse sentido, o modo como Cícero apresenta os oradores, distinguindo-os pelos cargos que ocuparam na república romana, parece remeter ao tipo de cortejo fúnebre relatado por Políbio. ${ }^{61}$

Além de estar presente no prólogo, a figura de Hortênsio volta à cena quando o diálogo se aproxima, nas palavras de Ático, de sua peroração. ${ }^{62}$ Seguindo a ordem cronológica da oratória romana - e que não seria exagero chamar também evolutiva ${ }^{63}$ —, que culmina na época em que atuavam Marcelo, César, Hortênsio e Cícero, a trama do diálogo tem como objetivo gerar no leitor a expectativa de que o relato alcance a época contemporânea e discorra sobre esses oradores. ${ }^{64}$ Cícero se recusa a tratar de oradores que ainda estão vivos e a falar sobre si mesmo, mas acaba tecendo algumas considerações sobre Marcelo, transferindo para Ático a responsabilidade de comentar a oratória de César. Quando é chegado o momento de fazer suas considerações sobre Hortênsio, Cícero escreve, por assim dizer, uma autobiografia intelectual. ${ }^{65}$ Ambas as carreiras, a partir de um certo momento, teriam seguido paralelamente, quando foram interrompidas ao mesmo tempo, em 50 a. C., no consulado de Paulo e Marcelo, pouco antes da eclosão da guerra civil: a de Hortênsio, em razão de sua morte, e a de Cícero, em razão da situação da república. ${ }^{66} \mathrm{O}$ argumento da morte da eloquência romana presente no prólogo se perfaz no epílogo, quando Cícero faz

\footnotetext{
${ }^{60}$ Cf. KenNedy 1972, pp. 21-23.

${ }^{61}$ Diversos estudos entendem o Brutus como uma laudatio funebris não só do orador Hortênsio mas também da própria oratória republicana. Cf. Douglas (1966, p. xi), NARducci (1997, p. 98), Gowing (2000, p. 58), Stroup (2003, p. 118) Dugan (2005, p. 173) e Marchese (2011, p. 41). É importante lembrar que essas homenagens eram privilégio dos patrícios: Cícero, por exemplo, não tinha direito a elas. Nesse sentido, o Brutus cumpre também a função de legar à posteridade uma laudatio Ciceronis.

${ }^{62} \mathrm{Cf}$. Brutus 292.

${ }^{63}$ NARDUCCI (1997, p. 133).

${ }^{64}$ Cf. Brutus 232 e 248.

${ }^{65}$ Dugan (2005, p. 203): "Cicero's biography in the Brutus is a type of self-writing that is qualitatively different from the traditional Roman forms of memoirs serving as political apologias. Instead of a text that serves to establish a biographical narrative in order to defend one's career against others' hostile accounts, Cicero yokes the story of his life to an overarching literary-historical narrative, thus presenting himself as the product of powerful evolutionary forces".

${ }^{66}$ Cf. Brutus 328 .
} 
coincidir a morte de Hortênsio e o fim do espaço público, a morte de Hortênsio e a morte da própria oratória republicana. ${ }^{67}$ Além disso, interessa a Cícero o elogio de Hortênsio sobretudo para a elevação de sua própria glória. ${ }^{68}$ Cícero diz que seguiu os passos de Hortênsio (imitatio), mas também que pretendia ultrapassá-lo (aemulatio), evitando seus erros e aproveitando suas qualidades. Nesse sentido, o diálogo também procura frisar as diferenças entre ambos, ${ }^{69}$ bem como situar Cícero na chamada polêmica aticista e asianista. $^{70}$ A oratória de Hortênsio era caracterizada como asiática. No Brutus (326), Cícero afirma que o estilo (genus) asiático de Hortênsio não era aprovado em pessoas mais velhas (non probantur haec senibus), mas era louvado pelos mais jovens (sed mirabantur adulescentes), e que este gênero oratório carecia de prestígio (auctoritas), podendo ser adequado quando se é jovem, mas inadequado quando se atinge a maturidade.

Na sequência do prólogo, Cícero volta o olhar sobre si mesmo e sobre a atual situação da república, aprofundando ainda mais a dimensão política e apontando uma causa para o deserto dos tribunais e assembleias, a saber, a imposição do poder das armas:

Equidem angor animo non consili, non ingeni, non auctoritatis armis egere rem publicam, quae didiceram tractare quibusque me adsuefeceram quaeque erant propria cum praestantis in re publica viri tum bene moratae et bene constitutae civitatis. quod si fuit in re publica tempus ullum, cum extorquere arma posset e manibus iratorum civium boni civis auctoritas et oratio, tum profecto fuit, cum patrocinium pacis exclusum est aut errore hominum aut timore.

\footnotetext{
${ }^{67}$ Fox (2007, p. 180): "But in spite of Cicero's attempt to distinguish between his own sense of grief at Hortensius' death and a form of grief which recognizes more objectively the actual fate of the deceased, the whole point of this opening presentation is precisely to conflate those two areas, by making the death of Hortensius into a symbol of the extinction of oratory at Rome which Caesar's dictatorship has brought with it, and to display, with a certain philosophical and stylistic sophistication, a kind of grief that will find collective recognition".

${ }^{68}$ DugAn (2005, p. 174): "It is the figure of Hortensius - his long career, distinguished ability, and ultimately unrealized potential - upon which the Brutus' grief over the premature death of Roman oratory crystallizes, and which also serves as the central foil for Cicero's self-presentation in the work".

${ }^{69}$ Dugan (2005, p. 215): "In his depiction of Hortensius Cicero engages in the delicate task of praising the honorand of his dialogue and acknowledging him as an important stylistic influence, while at the same time distinguishing himself from the Asianist excesses of Hortensius' style."

${ }^{70}$ Cf. NarducCi (1997, pp. 124-133), Dugan (2005, pp. 214-224).
} 
[De minha parte, angustia-me que a república não sinta falta das armas do discernimento, da inteligência, da autoridade, que eu aprendera a manejar e com as quais me habituara, e que eram próprias tanto de um homem de proeminência na república como de uma cidade de bons costumes e bem constituída. Mas se houve na república algum momento em que a autoridade e a palavra do bom cidadão eram capazes de arrancar as armas das mãos de cidadãos enfurecidos, certamente foi aquele em que a defesa da paz foi excluída fosse por imprudência dos homens fosse por medo.] (Brutus 7)

A palavra que mais nos interessa nessa passagem é arma, que ocorre duas vezes. No primeiro momento, arma carrega um sentido metafórico e positivo. No segundo, arma contém um sentido literal e negativo. As primeiras são as armas do discernimento, do engenho e da autoridade (consilium, ingenium, auctoritas), de que Roma carece no presente momento, que Cícero aprendera a manejar e que são próprias de toda cidade boa e bem constituída (bene moratae et bene constitutae civitatis). Em seguida, as armas a que Cícero se refere são aquelas que promovem sedições (iratorum civium), cuja força era sobrepujada pelo poder da autoridade (auctoritas) e da palavra (oratio) de bons cidadãos, no tempo em que era possível defender a causa da paz (patrocinium pacis). Esse duplo sentido de $a r m a^{71}$ parece indicar a distinção de uma dicotomia entre arma e oratio (7 e 8), laus bellica e laus dicendi (84), laudes bellicas e gloriam dicendi (239), orator e imperator (256), que parece permear o diálogo.

Quando Cícero inicia o relato sobre os oradores romanos (Brutus 53), em chave hiperbólica, ele sobrevaloriza, por assim dizer, as virtudes oratórias de importantes personagens da história política de Roma, deixando de lado suas "virtudes bélicas". Cícero sugere, por exemplo, que Lúcio Júnio Bruto (tido pelos historiadores como libertador e fundador da república $)^{72}$ conseguiu expulsar os reis e instituir em Roma o governo da

\footnotetext{
${ }^{71}$ Fox (2007, p. 181): "The contrast is between the arma of the Caesarian regime and those metaphorical arma, of consilium, ingenium, and auctoritas, which were Cicero's particular achievement, the result of his own education (didiceram)."

${ }^{72}$ Cf. Tito Lívio I, 56.
} 
lei e das magistraturas ${ }^{73}$ em razão de sua prudência (summam prudentiam) e de sua capacidade persuasiva (quod certe effici non potuisset, nisi esset orationem persuasum 53). Em seguida, menciona uma sucessão de acontecimentos históricos de Roma (na verdade, trata-se de conflitos entre patrícios e plebeus) nos quais a resolução das discórdias reside, por assim dizer, na capacidade oratória de alguns políticos romanos, fazendo valer o argumento do prólogo, que afirma que o discurso (oratio) e a autoridade (auctoritas) dos bons cidadãos eram capazes de conter as sedições (arma iratorum civium). Cícero credita à oratória do ditador Marco (ou Mânlio) Valério a resolução do conflito entre patrícios e plebeus (M. Valerium dictatorem dicendo sedavisse discordias 54), que resultou na criação do tribunado da plebe. ${ }^{74}$ Quando Roma era dominada pelos decênviros, houve uma outra grande sedição da plebe, cuja ira, segundo Cícero, foi aplacada por Lúcio Valério Potito, ${ }^{75}$ por sua eloquência (dicendo) e pela criação de leis (legibus). Mais adiante, falando sobre o engenho (ingenium) de Lélio e de Cipião Emiliano (83), sutilmente, ${ }^{76}$ Cícero contrasta dois tipos de glória: laus dicendi e laus bellica. Lélio se sobressairia pelo engenho, sabedoria e eloquência (ingenium, sapientia, eloquentia), a Cipião, por outro lado, ninguém superava na glória militar (ex bellica laude aspirare ad Africanum nemo potest). Falando de Pompeu Magno (239), Cícero afirma que ele teria alcançado maior glória na oratória se não tivesse um desejo maior de glória militar (maiorem dicendi gloriam habuisset, nisi eum maioris gloriae cupiditas ad bellicas laudes abstraxisset). Numa importante passagem do diálogo (253-257), há uma comparação do prestígio de que gozam na sociedade romana o orator e o imperator (o que pode sugerir uma comparação entre Cícero e César). ${ }^{77}$ Enquanto

\footnotetext{
${ }^{73}$ Brutus 55, [ele que baniu um rei tão poderoso, filho de um rei tão ilustre, e que sujeitou a cidade, libertada da tirania ininterrupta, a magistraturas anuais, leis e tribunais; ele que revogou o poder de seu colega, para que a cidade suprimisse a memória do título de rei] civitatem perpetuo dominatu liberatam magistratibus annuis legibus iudiciisque devinxerit; qui collegae suo imperium abrogaverit, ut e civitate regalis nominis memoriam tolleret.

${ }^{74}$ Cf. Tito Lívio II, 30-33

${ }^{75} \mathrm{Cf}$. Tito Lívio III, $52-55$.

${ }^{76}$ Referimo-nos à frase que antecede a comparação da glória oratória e intelectual com as glória das armas. Brutus 84, sed est mos hominum, ut nolint eundem pluribus rebus excellere.

${ }^{77}$ LOWRIE (2008, p. 136-137): "The discussion of Caesar not only establishes an implicit contrast with Cicero, but a number of elements that touch on sore points further go missing. These, however, leave traces. After citing Caesar's complimentary dedication to Cicero of his linguistic treatise De analogia, Cicero goes into an extended comparison of the relative merits of military and intellectual glory".
} 
comenta a oratória de César, Ático menciona o elogio a Cícero feito por César no seu De analogia. César teria considerado Cícero como o inventor da copiosidade (principem copiae atque inventorem) nas letras latinas. Bruto aprova o elogio, mas faz uma ressalva: afirma que a glória atingida por Cícero deve ser colocada à frente dos triunfos de muitos ${ }^{78}$. Esse comentário prepara a fala seguinte de Cícero, na qual ele sobrepõe o valor do orator ao do imperator. ${ }^{79}$ Cícero diz preferir um único discurso de Lúcio Crasso a dois triunfos. Cícero compara o orador e o general ao escultor e ao carpinteiro, respectivamente. ${ }^{80}$ Do ponto de vista da utilidade, o carpinteiro, tal como o general, pode ter maior valor, mas Cícero diz preferir o escultor e o orador.

Tais considerações parecem ser pertinentes se levarmos em conta o argumento do diálogo: a guerra civil pôs fim à oratória republicana, não há mais tribunais nem assembleias. No final do diálogo, Cícero retoma a ideia inicial da morte de Hortênsio como bem aventurada por não viver a atual situação da república:

saepe enim inter nos impendentis casus defleuimus, cum belli ciuilis causas in priuatorum cupiditatibus inclusas, pacis spem a publico consilio esse exclusam uideremus. sed illum uidetur felicitas ipsius, qua semper est usus, ab eis miseriis, quae consecutae sunt, morte uindicauisse. (Brutus 329)

[ De fato, muitas vezes, lastimamos entre nós as desgraças iminentes, quando víamos as motivações da guerra civil presentes em ambições privadas, e estava excluída a esperança de paz pela deliberação pública. Mas sua boa sorte, da qual sempre gozou, parece tê-lo livrado com a morte das desventuras que se sucederam.]

Além do lamento quanto à morte de um amigo e senador (uma perda no âmbito

\footnotetext{
${ }^{78}$ Brutus 255, Hanc autem, inquit, gloriam testimoniumque Caesaris tuae quidem supplicationi non, sed triumphis multorum antepono.

${ }^{79}$ Brutus 256, Verum quidem si audire volumus, omissis illis divinis consiliis, quibus saepe constituta est imperatorum sapientia salus civitatis aut belli aut domi, multo magnus orator praestat minutis imperatoribus.

${ }^{80}$ LOWRIE (2008, p. 137): "While the analogy between oratory (or poetry) and the visual arts is conventional - and frequent in the Brutus - the degradation of military achievement to the equivalent of carpentry is tendentious".
} 
do espaço privado e uma perda para a própria república num momento de deterioração do espaço público, como dissemos), Cícero também lamenta sua própria sorte. O curso natural de uma carreira política bem sucedida terminaria em uma velhice ociosa dedicada aos estudos. Isso não aconteceu a Cícero, sua carreira política foi interrompida pelo conflito das armas. O lamento agora é pessoal: a eloquência ciceroniana, que atingia sua maturidade, foi silenciada pela força das armas. A busca pela glória por meio das armas conduziu a um uso inadequado delas. O fim do espaço público dos tribunais e das assembleias força Cícero ao otium. Cícero afirma encontrar um porto seguro num ócio honesto e moderado, na forma de um otium operis. A sua eloquência (oratio) atingira sua maturidade e se aproximava da velhice, no momento em que o poder das armas (arma) predominava.

O prólogo, então, se encerra apresentando o diálogo como uma história (memoria) e lembrança (recordatio) de cidadãos bem-aventurados e bem-afortunados que puderam gozar da glória de seus feitos e do louvor de sua sabedoria. O que teria trazido a Cícero alguma alegria em meio às seríssimas preocupações do momento (Brutus 9).

\section{Cícero, Ático e Bruto: o intertexto}

Terminado o prólogo da persona auctoris, entram em cena as personagens do sermo. Caminhando em sua casa, Cícero recebe a visita de seus amigos Ático e Bruto. O encontro com os amigos era capaz de diminuir sua preocupação com os assuntos públicos (ut eorum aspectu omnis quae me angebat de re publica cura consederit 10). Inicia-se, então, o que chamamos anteriormente exórdio dialógico ou prólogo dramático (10-24). Cícero pergunta se os amigos trazem alguma notícia sobre a situação política. Ático afirma que não é esse o propósito da visita e estabelece o silêncio sobre os acontecimentos políticos (ut de re publica esset silentium 11). ${ }^{81}$ Em vez disso, ele diz preferir ouvir algo de Cícero a causar-lhe

\footnotetext{
${ }^{81} \mathrm{Na}$ verdade, o tema da política perpassa todo o diálogo, conforme aponta DUGAN (2005 p. 175): "Atticus' regulation of silence about politics, an action that appears consistent with his cautiously
} 
algum desconforto. Cordialmente, o anfitrião responde que os amigos confortam-no não só quando estão presentes mas também quando estão ausentes. ${ }^{82}$ Ausência que se faz presença através de certos escritos (litterae).

$\mathrm{Na}$ verdade, esses escritos eram a expressão do ambiente intelectual romano da época, no qual circulavam diversos e variados textos de história, oratória, filosofia, poesia, entre outros. Ático teria escrito e dedicado a Cícero uma obra de história, e Bruto, uma obra de filosofia. Nas palavras de Cícero, esses textos (litterae) teriam-no reanimado (recreatus), reconduzindo-o aos antigos estudos (pristina studia). Ático, então, afirma ter lido a carta (epistulam) que Bruto, da Ásia, enviara a Cícero. Conforme demonstra Hendrickson, seguindo referência feita pelo filósofo Sêneca (ad Helv. 8, 4), tratar-se-ia de um escrito sobre filosofia moral conhecido como De virtute, cujo conteúdo e propósito seriam revelados no breve comentário de Ático (qua mihi visus est et monere te prudenter et consolari amicissume "que a meu ver não só te aconselhava sabiamente mas também consolava de maneira muito afetuosa" 11). ${ }^{83}$ Depois do breve comentário de Ático, Cícero afirma que esse texto o aliviara de suas perturbações e como que o trouxera de volta à luz do dia (ad aspiciendam lucem esse revocatum). Bruto diz ter sido essa a intenção do seu escrito, mas revela curiosidade em saber qual obra (litterae) de Ático lhe teria causado tamanho contentamento (delectaverint 13). Cícero, por sua vez, enfatiza que, mais do que lhe proporcionar deleite (delectationem), o opúsculo do amigo lhe restituíra a saúde (salutem). ${ }^{84}$

Ático escrevera e dedicara a Cícero uma obra de história, um manual de cronologia

diplomatic character, far from effacing politics from the text, effectively politicizes the whole of the Brutus. The reader suspects that the work has veiled political significances which cannot be discussed openly."

${ }^{82}$ Brutus 10.

${ }^{83}$ Hendrickson (1939, p. 410): "The letter from Asia, which Cicero describes as having renewed in him life and hope, is characterized by Atticus as giving wise admonition and affectionate solace. That is exactly the purpose for which Seneca uses his citation from the de Virtute, and exactly what might be expected from the proposition that virtue of itself was sufficient for the happy conduct of life. This then was the admonition of which Atticus speaks, and how much Cicero needed it in that year of quasi-exile at Brundisium his letters of that time are eloquent witnesses. As for solace, we know also that the letter of Brutus sought to console Cicero by reminding him of his past merits toward the state and by assuring him that their memory was imperishable".

${ }^{84}$ Observe-se que, em carta de 46 a. C. endereçada a Varrão (Ad fam. IX, 2, 4), Cícero afirma que a vida voltada para os estudos promoveria não só um deleite (delectationem) mas também sua própria saúde (salutem). 
conhecido como Liber annalis, e seu tema é sintetizado nas palavras de Bruto: Tum ille [Brutus]: nempe eum dicis, inquit, quo iste omnem rerum memoriam breviter et, ut mihi quidem visum est, perdiligenter complexus est? "Bruto, então, disse: — Você está certamente se referindo àquele livro em que ele abarcou toda a história de modo breve e, pelo menos segundo me parece, com muita diligência?" (Brutus 14). Trata-se de um manual de cronologia sobre a história de Roma desde suas origens, organizado segundo a sucessão das magistraturas, apresentando as atividades legislativas, as guerras, os tratados de paz e importantes acontecimentos de Roma e da Grécia, bem como um quadro genealógico de nobres famílias romanas. ${ }^{85}$ Cícero afirma que este livro lhe restituíra a saúde (mihi salutem fuisse). Ático, então, indaga qual teria sido a novidade ou a utilidade da obra. Cícero responde que não só havia muita novidade ( nova multa) mas principalmente algo bastante proveitoso e do qual ele estava em busca, a saber, a visada histórica do liber annalis: completa (omnia), concisa (uno in conspectu) e bem ordenada (ordinibus temporum).

De fato, Cícero se coloca no dever de retribuir (remunerandum) o presente (munere). Valendo-se de um preceito de Hesíodo ${ }^{86}$ — que prescreve a necessidade de se restituir (reddere) na mesma medida, ou em grau maior, aquilo que se ganhou - Cícero afirma que só será capaz de corresponder à intenção (voluntatem), não ao valor em si (rem ipsam), das homenagens a ele prestadas. ${ }^{87}$ Para explicar por que não retribuirá, por assim dizer, o valor exato do débito, Cícero formula uma metáfora agrícola. Estabelecendo uma diferença entre frutos recém-colhidos (novis fructibus) e frutos estocados (conditis), Cícero afirma que não se valerá de nenhum deles para quitar sua dívida, mas que semeará algo

\footnotetext{
${ }^{85}$ Cf. NARDUCCI (1997, p. 103): "Si trattava, a quanto pare, di un manuale di cronologia, dedicato a Cicerone, che ordinava, attraverso il succedersi delle magistrature, l'intera storia di Roma dalle origini fino all'epoca contemporanea: vi trovano posto l'attività legislativa, le campagne belliche, i trattati di pace, e tutte le più importanti vicende della città; un certo spazio era dedicato all'attenta ricostruzione delle genealogie delle famiglie illustri; ed è supposizione attendibile che vi fosse delineata anche una sinossi con gli avvenimenti della storia delle altre nazioni, soprattutto della Grecia".

${ }^{86}$ Cf. Hesíodo (Trabalhos e dias, 348 ss.)

${ }^{87}$ Quando Cícero, em 45 a. C., escreve a Varrão (Ad fam. IX, 8), informando-o sobre a escrita dos Academica, obra em que ambos são personagens que discutem o problema do conhecimento nas doutrinas acadêmicas, ele se utiliza do mesmo vocabulário do munus e do remunerari. Trata-se de uma referência ao De lingua latina de Varrão, que seria dedicado a Cícero.
} 
em terreno não cultivado e abandonado (seremus igitur aliquid tamquam in inculto et derelicto solo 16), cultivando-o com diligência para que se possa aumentar a grandeza do presente (muneris). Finaliza-se essa alegoria com o paralelo entre seu estado de espírito (noster animus) e o campo (ager): um campo que esteve em repouso (quievit) por muitos anos costuma ter maior abundância de frutos (uberiores efferre fruges solet 16).

Nesse passo de seu comentário do Brutus, Douglas menciona a dificuldade de interpretação da passagem, lembrando que mais adiante Cícero promete seu pagamento a Ático (Brutus 19) e que, na hipótese de Hendrickson (1939), o pagamento do débito com Bruto é o próprio Brutus, de modo que o diálogo sobre a história da oratória romana provavelmente seria dedicado não só a Bruto mas também a Ático. ${ }^{88}$

As personagens seguem negociando como serão feitos o pagamento e a cobrança da dívida. Os credores Ático e Bruto se colocam como procuradores um do outro, que reclamarão seu crédito. Não intransigente, mas exigente, Ático cobra de Cícero o que é devido a Bruto: que ele escreva algo (ut scribas aliquid), já que depois dos livros sobre a república (de re publica libros) seus escritos silenciaram (conticuerunt tuae litterae 19). E teriam sido esses livros que incitaram e impulsionaram Ático a escrever seu Liber annalis. Logo em seguida, Ático pede a Cícero que faça uma exposição (expone nobis) sobre os oradores (de oratoribus), retomando uma conversa que ambos teriam iniciado em Túsculo sobre quando surgiram, quem foram eles e que valor possuíam como oradores (quando esse coepissent, qui etiam et quales fuissent 20). Conversa (sermo) que Ático teria referido a Bruto, cujo interesse em ouvi-la do próprio Cícero teria sido o motivo daquela visita (itaque hunc elegimus diem, cum te sciremus esse vacuum). As palavras de Ático parecem confirmar que o diálogo é dedicado não só a Bruto mas também a ele mesmo (quare, si tibi est commodum, ede illa quae coeperas et Bruto et mihi 20).

\footnotetext{
${ }^{88}$ Douglas (1966, p. 10-11): "Possibly the offering to Atticus is also Brutus, which, while named after Brutus, is not specifically dedicated to him, and is largely based on Atticus' researches. The elaborate fencing of Brutus and Atticus, each undertaking to dun Cicero on behalf of the other, is a hint that the work is a gift to both, and aliquid in seremus aliquid (16) is the same as in scribas aliquid (19)". Most comm. take inculto...solo of a type of writing, and it would then refer to the 'field' covered by Brutus, a novel undertaking [...]. But surely Cicero is referring to his own mind and creative faculties, noster animus (16) cf. orator 48.
} 
Cícero, então, lembra que a conversa com Ático teria surgido de uma menção à causa do rei Dejótaro, cuja defesa fora feita por Bruto de modo bastante rico e ornado (ornatissume et copiosissume). Ático confirma e acrescenta que Cícero lamentara a sorte de Bruto em razão da desolação do fórum e das assembleias (teque Brute dolentem vicem quasi deflevisse iudiciorum vastitatem et fori 21). Lamento que é reiterado por Cícero (feci istuc quidem et saepe facio), que atribui a Bruto um engenho admirável (natura admirabilis), o domínio da arte (exquisita doctrina) e uma laboriosa exercitação (singularis industria). Pertencentes a gerações (aetates) diversas mas que sofrem do mesmo infortúnio, Cícero e Bruto veem a decadência das instituições romanas e principalmente o silêncio da eloquência (eloquentia obmutuit).

A presença das personagens Ático e Bruto não só teria motivado a escrita da obra, mas também desempenharia papeis relevantes no argumento geral do diálogo, na medida em que o Brutus estabelece um diálogo com o De virtute e com o Liber annalis. ${ }^{89}$ Bruto é a personagem mais jovem. São, portanto, duas gerações de oradores. Assim como no $D e$ oratore, os mais jovens eram Cota e Sulpício, e os mais velhos Crasso e Antônio. Na chave da transmissão de uma geração para a seguinte, insere-se a relação entre as personagens Cícero e Bruto, no que concerne aos princípios ético-políticos e retórico-discursivos. ${ }^{90} \mathrm{O}$ De virtute, segundo Hendrickson, era como que uma carta consolatória fundamentada no estoicismo que advertia que a virtude em si mesma era suficiente para a vida feliz, sendo exemplo disso o exilado Marcelo, que teria encontrado consolação em seus estudos, a quem Bruto visitara em Mitilene. ${ }^{91}$ Dugan $(2005$, p. 241) formula a hipótese, com a qual

\footnotetext{
${ }^{89}$ DugAn (2005, p. 177): "Cicero's reaction to texts dedicated to him by each of these authors Caesar's work on linguistic theory (De analogia), Atticus' tabular chronology of Roman history (Liber annalis), and Brutus' ethical treatise (De virtute) — articulates vital themes within the Brutus: Cicero's debate with Caesar over linguistic theory offers a judiciously indirect response to Caesar's hegemony; intertexts with Atticus' Liber annalis allow Cicero to authorize the Brutus' views of historical development, while setting the stage for unravelling that account in the ironic conclusion of the work; and the Brutus reacts to Brutus' De virtute by reinterpreting its notion of proper ethical conduct and thus offers Brutus a counter-protreptic which, in its enigmatic advice to Cicero's hoped for protege on an orator's proper response to Caesar's domination of Rome, creates a synthesis of the political and literary themes which animate the dialogue".

${ }^{90}$ DugAn (2005, p. 234): "Cicero combines political and oratorical overtures to Brutus, hoping to win Brutus over to Ciceronian political and aesthetic principles".

${ }^{91}$ Cf. Hendrickson (1939, p. 412).
} 
concordamos, de que, no De virtute, Bruto pretenderia consolar Cícero com a ideia de que, ainda que tivesse que permanecer em silêncio no presente momento, seu legado político falaria por si mesmo e que sobreviveria à sua morte (Brutus 330). Segundo ele, a exortação de Bruto no De virtute defenderia como que uma espécie de razão preguiçosa, quietismo, aceitação dos acontecimentos, enquanto o Brutus, como uma espécie de contra-protréptico, responderia a isso de duas maneiras, a saber: de um lado, Cícero defenderia que ele mesmo também serviria de exemplo a Marcelo, e, por outro lado, Cícero proporia uma outra definição de virtude. Por um lado, a conduta de Marcelo guardaria traços ciceronianos, ${ }^{92}$ e, por outro lado, o Brutus seria entendido como uma espécie de laudatio funebris, que também é uma forma de atuação ético-política por meio da escrita, fazendo o elogio dos maiores e defendendo que a virtude não se encontra no âmbito do espaço privado, mas sim na emulação daquilo que se fundamenta numa tradição ancestral e comum, que se situa no âmbito do espaço da cidade (civitas, res publica) ${ }^{93}$

Quanto à presença de Ático, os estudos apontam que o Liber annalis teria sido uma importante fonte de informação e autoridade para o relato histórico do Brutus. A figura do amigo e estudioso da história romana já havia sido representada no De legibus. Esse diálogo, que Cícero não chegou a concluir, tinha como personagens seu irmão Quinto, Ático e o próprio Cícero. No "exórdio dialógico" do primeiro livro, a personagem Ático se refere a certo poema escrito por Cícero em louvor de seu concidadão Caio Mário (153-86 a. C.). Ático afirma que os leitores do poema querem saber se o que é relatado nele é verdade ou não (Atqui multa quaeruntur in Mario fictane an uera sint. [De legibus I, 4]). Cícero, então, adverte para o fato de que a poesia e a história diferem enquanto gêneros e

\footnotetext{
${ }^{92}$ Dugan (2005, p. 242-243): "Marcellus therefore stands as an exemplum of an orator's successful imitation of Ciceronian oratorical practice and Cicero's general educational theories as well, since Marcellus engaged in philosophical studies that Cicero describes with the term copia, a hallmark of Ciceronianism. As a gentle reply to what may have been a somewhat tactless suggestion that Cicero needed to achieve the sort of virtus that Marcellus had attained in exile, Cicero has his 'Brutus' make Marcellus' actions an implicit imitation of Cicero".

${ }^{93}$ Dugan (2005, p. 243-244): "Cicero here takes the central term of philosophical protreptic and reformulates it into a different kind of virtus. In essence, Cicero argues that the sort of virtus which is more authentically Brutus', and the sort of virtus that the current political circumstances demand, is not the individualistic virtus (as calque for Greek arete) of the Hellenistic philosophical schools, but its traditional aristocratic form of emulating the valorous deeds of one's ancestors".
} 
possuem preceitos diversos, na medida em que a história trataria da "verdade" (veritatem) enquanto a poesia buscaria deleitar (delectationem).${ }^{94}$

Na sequência do De legibus, Ático aproveita a oportunidade para solicitar, ou mesmo exigir, de Cícero a tarefa de enriquecer as letras latinas com a escrita de uma obra historiográfica. Quinto diz ter discutido sobre isso com o irmão e menciona uma divergência (dissensio) entre eles. A questão é a seguinte: a partir de quando é que se deve começar a escrever a história (A quibus temporibus scribendi capiatur exordium I, 8)? Na opinião de Quinto, a partir da época mais remota ( $a b$ ultimis). Mas Cícero acha que a história (memoria) deve versar sobre a época contemporânea (aequalis aetas). No De legibus, Ático concorda com a perspectiva de Cícero. No Brutus, no entanto, a dissensio, por assim dizer, é entre Ático e Cícero, entre o historiador e o orador. O Liber annalis conteria setecentos anos da história de Roma em um único volume. ${ }^{95}$ Esse relato teria permitido a Cícero organizar sua história da oratória romana, tomando-o como "manual histórico" para a organização cronológica do Brutus.

\section{O Brutus e o Liber annalis}

No Brutus, é a partir do pedido da personagem Ático que Cícero relata a conversa que ambos teriam tido em Túsculo acerca dos oradores: "quando surgiram, quem eram e também quais eram as suas qualidades" (quando esse coepissent, qui etiam et quales fuissent 20). O Liber annalis de Ático funcionaria como fonte histórica, apresentando informações sobre eventos políticos não só de Roma mas também da Grécia, bem como sobre magistraturas e genealogias de famílias nobres romanas. Por um lado, a obra de Ático funciona como uma fonte importante para a obra de Cícero ${ }^{96}$ e, por outro lado, a personagem Ático desempenha um papel crítico diante do relato da personagem Cícero,

\footnotetext{
${ }^{94}$ De legibus I, 5.

${ }^{95}$ Orator 120.

${ }^{96}$ DugAn (2005, p. 190): "Atticus, as author of the Liber annalis, serves as the guarantor of the dialogue's historical accuracy, while Cicero shows himself willing to sacrifice precise historicity to achieve rhetorical effects."
} 
ressaltando as diferenças entre ambos. ${ }^{97}$ As intervenções de Ático são pontuais, e é possível dizer que suas objeções assumiriam a função da disputatio in utramque partem. ${ }^{98} \mathrm{Em}$ duas passagens (Brutus 42-3; 292-7), Ático, sob a perspectiva do historiador, se contrapõe à perspectiva do relato de Cícero.

No início do diálogo (Brutus 42-3), Cícero procura estabelecer em seu relato um paralelo entre Temístocles e Coriolano, afirmando que ambos tiveram mortes semelhantes, por suicídio. O próprio Cícero reconhece que há divergência entre os historiadores, ou seja, que no próprio relato de Ático a história é contada de modo diverso. Ele então pede ao amigo historiador que lhe conceda contar a história dessa maneira. Ático menciona dois testemunhos diversos sobre a morte de Temístocles, a saber, o relato de Tucídides e o relato de Clitarco e Estrátocles. No primeiro, a historia teria sido contada com maior veracidade, e nele o suicídio de Temístocles seria apenas uma suposição; no segundo, a historia teria sido adornada e embelezada com uma morte trágica: depois de fazer um sacrifício e beber o sangue da vítima sacrificial, Temístocles teria caído morto. Ático concede e afirma que "é permitido aos rétores mentir em seus relatos históricos, para poderem dizer algo com maior expressividade" (concessum est rhetoribus ementiri in historiis, ut aliquid dicere possint argutius 42). Primeiro sinal da divergência entre as perspectivas historiográficas de Ático e Cícero. Tornar o relato mais expressivo (argutius) quer dizer ornamentar a narração da morte de maneira retórica e trágica (mortem rhetorice et tragice ornare 43), "subvertendo", assim, as leis da história. 99

\footnotetext{
${ }^{97}$ Dugan (2005, p. 191): "In an exchange between Atticus and himself early within the dialogue, Cicero signals how his views of history diverge from those of his friend, and he distinguishes his own goals in the Brutus from a purely chronological enterprise like Atticus' Liber annalis. The Brutus thus foreshadows the tension between Atticus' and Cicero's views of history that will erupt at the conclusion of the dialogue. Cicero presents the Brutus not as a disinterested undertaking, but one instead driven by its own persuasive and protreptic, that is, 'rhetorical', objectives".

${ }^{98}$ NARDUCCI $(1997$, p. 106).

${ }^{99}$ Essa passagem lembra a famosa carta de Cícero a Luceio, Ad fam. V, 12. Segundo Guillemin (1938, p. 97), "Il s'agissait donc d'une lettre accurate scripta, c'est-à-dire destinée à circuler dans le publique lettré". A aproximação dos termos no Brutus, a saber, ementiri in historiis, ornare, tragice e rhetorice, e na carta a Luceio, a saber, ut ornes...et in eo leges historiae neglegas, parecem revelar uma concepção ciceroniana da escrita da história que se aproxima mais do que poderíamos chamar de "história retórica", ou mesmo "história poética", tendo como referência a perspicaz interpretação da estudiosa francesa, segundo a qual Cícero, nessa carta, desenvolve a teoria aristotélica da tragédia. Guillemin (1938, p. 101): "Il me semble clairement établi maintenant qu'à travers toute la lettre de Cicéron apparaît par transparence, mais nettement, la doctrine aristotélicienne de la tragédie".
} 
Na sequência do diálogo (Brutus 99), Ático faz outra intervenção no relato de Cícero. Nesse momento, trata-se de discutir uma informação controversa entre os historiadores a respeito de um discurso de certo Caio Fânio. Ático parece "corrigir" ou, ao menos, contrapor outros testemunhos acerca da atribuição de autoria desse discurso. Ático afirma que essa atribuição é controversa: alguns atribuem o discurso a Caio Pérsio, ao passo que outros afirmam que o discurso foi composto por diversos nobres. Cícero, então, diz ter ouvido (audivi) isso de pessoas mais velhas (maioribus). No entanto, podemos entender, segundo o já mencionado argumento de Hendrickson, que seria uma referência a outras fontes escritas que Cícero teria consultado, ou mesmo que teriam sido reportadas pelo próprio Ático no Liber annalis. Nessa passagem, portanto, Ático parece cumprir a função de autoridade em história romana (auctor rerum Romanarum). ${ }^{100}$

Enfim, o diálogo vai se aproximando de sua conclusão. É quando Ático faz uma crítica a Cícero (Brutus 292-7), acusa-o de ter sido irônico, à maneira de Sócrates, ao atribuir tanto valor aos oradores mais antigos, por exemplo, ao comparar Catão a Lísias (293) e ao afirmar que o discurso de Crasso pela lei Servília tinha sido como que seu mestre (296). Ático propõe um critério mais seletivo para o relato de Cícero. O objetivo dessa passagem é marcar a diferença entre a perspectiva do historiador, autor do Liber annalis, e a perspectiva do orador, autor do Brutus. Na visão de Ático, uma história da oratória latina deveria conter somente os oradores "propriamente ditos", ou seja, a partir da geração de Crasso e Antônio. Na visão de Cícero, é preciso ressaltar a qualidade dos oradores de acordo com a época em que atuaram. Além disso, os mais recentes podem se valer de toda a tradição anterior para se aperfeiçoar na oratória, enquanto os mais antigos não tinham essa vantagem. É importante lembrar que a história narrada por Cícero, além de estabelecer um critério diacrônico em oposição ao sincrônico de Ático, ${ }^{101}$ segue um

\footnotetext{
${ }^{100}$ Uma outra intervenção de Ático no diálogo não diz respeito à discussão sobre a escrita da história. Podemos dizer que é propriamente uma questão retórica, a saber, "ao aprovar ou reprovar um orador sempre a opinião do vulgo coincide com a opinião dos entendidos no assunto?" (semperne in oratore probando aut improbando uolgi iudicium cum intellegentium iudicio congruit 183). Essa questão permite a Cícero desenvolver alguns temas que não discutiremos aqui mas que convém mencionar, como por exemplo, os officia oratoris e a distinção entre os discursos mais voltados para as multidões, tal como a oratória, e os discursos mais voltados para os especialistas, como, por exemplo, a poesia (191)

${ }^{101}$ Cf. Dugan (2005, p. 190).
} 
curso evolucionário e teleológico, culminando na época e na pessoa de Cícero, produto de todo o desenvolvimento da oratória latina. É na perspectiva do elogio que Cícero exalta os oradores latinos em detrimento dos gregos. Nas palavras de Dugan, é na forma de uma "narrativa retórica" que tal elogio sedá, empenhada no mos maiorum, na medida em que é também uma laudatio funebris da morte da eloquência desempenhando as funções memorial e exortativa do funeral aristocrático. ${ }^{102}$

O elogio dos oradores latinos e a exposição de seu desenvolvimento durante séculos culminaria no surgimento de um orador como Cícero. Assim, o diálogo se aproxima de seu fim (telos), a saber, a autobiografia.

\section{O Brutus enquanto autobiografia ciceroniana}

Quando a história da oratória romana no Brutus chega à época de Cícero, o diálogo se torna uma autobiografia. Num primeiro momento, Cícero se recusa a falar de si mesmo, afirmando que outros o farão, se quiserem. ${ }^{103}$ Essa afirmação nos faz pensar no discurso Pro Archia e na famosa carta a Luceio (Ad fam. V, 12). Como se sabe, na defesa do poeta Árquias, Cícero implicitamente solicita um poema sobre o seu consulado e, nessa carta a Luceio, explicitamente, pede a Luceio que escreva uma história de seu consulado. ${ }^{104} \mathrm{Nem}$ Árquias nem Luceio escreveram sobre Cícero, cabendo a ele mesmo escrever a historia sui.

Por insistência de Bruto, Cícero consente em falar sobre si mesmo, já que Bruto não solicita um relato acerca de seu ingenium, mas sim de seu labor (Brutus 233). O Brutus

\footnotetext{
${ }^{102}$ Dugan (2005, p. 195): "As a sort of laudatio funebris delivered in honour of the death of eloquence, the Brutus performs the memorializing and protreptic functions of the aristocracy's funeral".

${ }^{103}$ Brutus 231: "Sobre mim, outros falarão, se lhes aprouver." de me alii dicent, si qui volent.

${ }^{104}$ Dugan (2005, pp. 23-4: "By transforming the legal case of the Pro Archia into an epideictic speech that seeks to use the cultural value of poets and poetry to naturalize Archias as a Roman citizen, Cicero shapes the speech into a text that carries out several simultaneous cultural transactions: it argues that literary texts are a legitimate technology of self-presentation within Roman culture; it becomes an item of exchange in a negotiation with Archias that seeks to obligate the poet to write a laudatory poem on Cicero's behalf whose content and tone the speech subtly prescribes; and it becomes Cicero's own proleptic funeral oration, thus enabling the novus homo to coopt an aristocratic representational mode(..) A letter written in 55, Cicero's private solicitation for an ornate laudatory historical monograph from Lucceius (Fam. 5. 12), parallels his negotiations with Archias and makes clear what literary 'polish' should provide, namely, a version of events that smoothes away traces of unflattering incidents from the author's narrative."
} 
enquanto autobiografia se distingue dos tradicionais escritos romanos de memórias que cumpriam a função de apologia política, tais como os que são mencionados no diálogo: os livros de Marco Escauro (112) e Quinto Cátulo (132), perdidos no esquecimento, pois ninguém os lê. ${ }^{105}$ Colocado num horizonte mais amplo do que o horizonte político, o Brutus busca se inserir na história cultural romana. ${ }^{106}$

\section{Persona Ciceronis}

Como já dissemos, se não considerarmos o De legibus, como o fez o próprio Cícero no "catálogo" de suas obras, ${ }^{107}$ o Brutus é o primeiro diálogo em que Cícero é personagem do drama. Lembremos das críticas de Salústio ${ }^{108}$ com relação às personagens escolhidas por Cícero para o De republica e notemos que na obra seguinte, Brutus, Cícero, pela primeira vez, aparece como personagem do drama. Isso nos leva a supor que, no Brutus, Cícero parece preocupado em construir uma persona sui, bem como dotá-la de auctoritas. É verdade que no De oratore e no De republica Cícero já está constituindo uma persona auctoris, mas, no Brutus, essa persona é apresentada de uma forma mais ampla.

Na primeira seção do diálogo, Cícero se mostra como ocupante de magistratura e áugure. ${ }^{109}$ A honra de ser um áugure é uma distinção romana de grande valor. Mas é no final do diálogo que Cícero faz propriamente sua autobiografia.

Lembremos o fato de que Cícero não era de origem patrícia. Assim, Cícero não dispunha dos mesmos meios de distinção. Por exemplo, o privilégio de uma laudatio funebris e o uso das imagines era uma honra exclusiva do patriciado. Ao fazer do Brutus uma laudatio funebris, Cícero se insere nesse grande cortejo da oratória romana e promove o texto

\footnotetext{
${ }^{105}$ tres libri quos nemo legit 112, qui liber nihilo notior est quam illi tres, de quibus ante dixi, Scauri libri 132.

${ }^{106}$ DugAn (2005, p. 214): "Cicero's ambitions are not limited to winning a temporary political scuffle. He intends to claim for himself a dominant position within Roman cultural history in a text that will achieve enduring canonicity."

${ }^{107}$ De div. II, 3-4. Como já observado, no prólogo do Brutus (19), Ático menciona o De republica como a última obra escrita por Cícero até aquele momento.

${ }^{108}$ Ad Q. Fr. III, 3 .

${ }^{109}$ Cícero utiliza o termo técnico decedens (deixar uma província) e menciona o fato de ter sido cooptado por Hortênsio no colégio dos áugures.
} 
escrito como uma imago ingeni sui. Ao longo de sua autobiografia, Cícero apresenta seu cursus honorum e ressalta o fato de ter alcançado essas honras na idade mínima (suo anno) até chegar ao consulado.

Cícero também fala sobre sua formação, mostrando conhecimentos de história, direito, filosofia e retórica. Ele ressalta sua diligência (labor et industria) e seu exercício de aprimoramento constante. 


\section{Cícero e a polêmica com os "aticistas"}

Neste capítulo, abordaremos a polêmica de Cícero com os chamados "aticistas" no Brutus. Num primeiro momento, trataremos da questão da natureza do "aticismo". Em seguida, analisaremos a relação de Cícero com aquele que supostamente queria ser chamado ático, Licínio Calvo, e com alguns outros personagens que guardariam certas semelhanças com o que seria considerado "ático". Também trataremos da relação de Cícero com o genus orationis Asiaticum e com um expoente dessa oratória, Quinto Hortênsio.

\section{O que é o "aticismo"?}

Foi bastante conhecida na antiguidade certa controvérsia que se teria desenvolvido por meio de algumas cartas trocadas entre Cícero e os jovens Calvo e Bruto acerca do gênero oratório, sobre as quais restam dois célebres testemunhos, o de Quintiliano e o de Tácito. ${ }^{110}$ Grande parte dos estudiosos usa o termo estilo para se referir àquilo que Cícero caracteriza como genus dicendi ou genus orationis. Desse modo, essa controvérsia se torna uma "polêmica de estilo", e seus partidários fariam parte de um "movimento". Nessa polêmica, haveria os defensores do gênero "ático" (Calvo, por exemplo), que se contrapunham a Cícero, considerado "representante" de um gênero oratório degenerado, denominado "asiático". Entre as obras supérstites que testemunham essa polêmica está o Brutus.

Com efeito, é no Brutus que encontramos uma das poucas caracterizações do que seria o genus orationis Asiaticum (325). No diálogo, Cícero afirma que a eloquência nasceu e se desenvolveu (et nata et alta 39) na Ática e se degenerou peregrinando pela

\footnotetext{
${ }^{110}$ Quintiliano, Inst. Or. XII, 10, 12, e Tácito Dial. 18, 5.
} 
Ásia (peregrinata tota Asia), reafirmando certa valorização do "ático" em detrimento do "asiático". 111 Mas, afinal, o que é o "aticismo"? Ou melhor, o que defendem os que pretendem ser "aticos"?

A controvérsia entre Cícero e os "aticistas" também gera uma controvérsia entre os estudiosos. No entanto, malgrado as divergências, a interpretação mais comumente aceita é que o que se conhece como "aticismo" na oratória foi um fenômeno peculiar da cultura romana do século I a. C. ${ }^{112}$ No contexto romano, podemos dizer que o "aticismo" surge como contraposição ao gênero oratório de Hortênsio e de Cícero ${ }^{113}$ e que os "aticistas", em linhas gerais, se é que assim podem ser chamados, preconizavam a pureza na dicção e a pronúncia urbana e arcaizante (Latinitas, Romanitas, urbanitas, antiquitas), bem como os princípios da analogia em gramática e um genus dicendi, ou genus orationis, tenue, exile, subtile. ${ }^{114}$ Não se trata, evidentemente, de um "movimento", mas sim de

\footnotetext{
${ }^{111}$ Brutus 51: [De fato, assim que a eloquência foi exportada do Pireu, viajou por todas as ilhas e de tal forma percorreu toda Ásia que se contaminou de hábitos estrangeiros e perdeu toda aquela salubridade e, por assim dizer, sanidade da diç̧ão ática, quase desaprendendo a falar. Foi então que surgiram os oradores asiáticos, não desprezíveis pela fluência nem pela copiosidade, é certo, mas pouco sóbrios e demasiado redundantes; os da ilha de Rodes são mais sóbrios e mais semelhantes aos áticos.] nam ut semel e Piraeo eloquentia evecta est, omnis peragravit insulas atque ita peregrinata tota Asia est, ut se externis oblineret moribus omnemque illam salubritatem Atticae dictionis et quasi sanitatem perderet ac loqui paene dedisceret. hinc Asiatici oratores non contemnendi quidem nec celeritate nec copia, sed parum pressi et nimis redundantes; Rhodii saniores et Atticorum similiores.

${ }^{112}$ HendRICKSON (1926, p. 236): "Roman Atticism was no abrupt or sudden development, though the name itself, Attici, genus Atticum, etc., seems only to have come into vogue about the middle of the first century B. C., and among Romans at all events was apparently first employed by Calvus in application to himself, through whom it gained currency as the designation of a larger miscellaneous group."; KENNEDY (1962, p. 242): "thus it seems best to regard Atticism as something developed in Rome in the period around 50 B. C."; Douglas (1966, p. xiii): "it suggests also that the Atticism developed after 54, when De oratore was published, since that work contains no indisputable allusion to the controversy, and perhaps mainly during Cicero's absences from Rome from on 51 onwards, and that it disappeared as an active movement as suddenly as it had emerged"; NARDUCCI, (1997, p. 125): "un fenomeno peculiare della cultura romana, una moda forse poco più che effimera, sviluppatasi nel deccenio succesivo alla pubblicazione de de oratore (54 a. C.)"; Sтroh (2010, p. 219): "Notons déjà que ce n'est qu'à partir de la fin des années - 50 qu'il devint habituel à Rome de désigner un certain style oratoire dégénéré par le vocable 'asiatique', les tenants de ce style étant des Asiani ou des Asiatici, qu'on opposait aux nobles Attici."

${ }^{113}$ HENDRICKSON (1926, pp. 237-8): "From various sources therefore and for different reasons we find Brutus and Calvus, and a considerable group of other orators and public men at Rome (Caesar, Calidius, Cornificius, and a little later Messalla and Asinius) united in opposition to the ideals and style of oratory which Hortensius and Cicero had brought to a kind of classical perfection."

${ }^{114}$ HENDRICKSON (1926, pp. 236-7): "Atticism in its origins was less a matter of style than of diction.

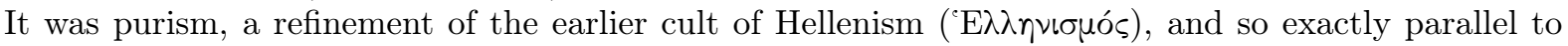
Latinitas. [...] This cult of purism, of faultless Latinity, was intimately associated with the theoretical study of grammar, and throve at Rome under the rivalries of analogists and anomalists." NARDUCCI (1997, p. 125): "oltre alla consolidata tradizione di un'eloquenza di stile piano e conciso, l'attenzione
} 
uma, ou mais de uma, concepção oratória que valorizava uns e/ou outros desses preceitos, partilhada por alguns que, por essa razão, seriam considerados "aticistas". Sobre esses que são considerados ou autodenominados "aticistas", podemos afirmar que na oratória o principal rival deles é o gênero copioso e exuberante de Hortênsio e Cícero.

A defesa de Cícero diante das acusações dos "aticistas" é um dos propósitos da escrita do Brutus e do Orator. ${ }^{115}$ No Brutus, ao fazer sua autobiografia, Cícero expõe e justifica sua concepção oratória. Ao apresentar uma história da oratória, Cícero contrapõe dois gêneros de eloquência "rivais", que ecoariam a polêmica com os chamados "aticistas". ${ }^{116}$

\section{Latinitas, urbanitas e imitatio antiquitatis}

De fato, a controvérsia dos genera orationis, ou dos genera dicendi, está explicitada no Brutus e no Orator, mas já no De oratore, segundo afirmação também controversa de Hendrickson, Cícero teria feito uma consideração polêmica acerca de uma noção cara aos "aticistas", a saber, a noção de Latinitas. Afirmação que teria motivado a resposta de César apresentada no seu De analogia. ${ }^{117}$ Latinitas seria o equivalente latino para o termo grego “E $\lambda \lambda \eta \eta v ı$ เós, que, por sua vez, se relaciona com o noção gramatical de "aticismo". ${ }^{118}$ Segundo a definição estoica citada por Diógenes Laércio (VII, 59), Helenismo é a correção

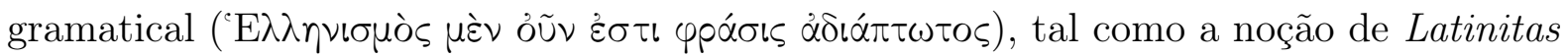

scrupolosa per la purezza del linguaggio (Latinitas), che si era delineata già in ambiente scipionico e continuava nel movimento analogista."

${ }^{115}$ Dugan (2005, p. 215): "Cicero's defence of his style against the criticism of his Atticist adversaries is the main preoccupation of both the Brutus and the Orator; Wisse (2002, p. 364): "As is well known, Cicero's main purpose in Brutus and Orator, written in 46 B.C., is to defend himself against the so-called Atticists."

${ }^{116}$ NARDUCCI (1997, p. 114): "Ė notevole, di conseguenza, l'importanza accordata alla contraposizione dei due stili nella ricostruzione delle vicende dell'eloquenza romana: una ricostruzione cui le esigenze della presa di posizione nei confronti delle atticisti si saldano con quelle della giustificazione delle scelte oratorie dello stesso Cicerone. Riconoscere ciò non equivale a negare l'obiettiva validità storiografica della distinzione dei due stili dell'oratoria, né tanto meno ad attribuire ad essa carattere artificioso o una valenza esclusivamente polemica."

${ }^{117}$ HeNDRICKSON (1906, pp. 97-8): "the treatise of Julius Caesar De analogia, owed its origin to certain utterances contained in the third book De oratore, relative to the importance of and the means of attaining to a pure Latinity."

${ }^{118}$ HENDRICKSON (1906, p. 98): "Atticism as the designation of a grammatical-rhetorical ideal was merely a narrower limitation and sharper definition of the older term Hellenism." 
na definição do autor da Rhetorica ad Herenium. ${ }^{119}$

Numa passagem do terceiro livro do De oratore (III, 37-55), a personagem Crasso trata da elocutio e discorre sobre as quatro virtudes do discurso, Latinitas, perspicuitas, decorum e ornatus. ${ }^{120}$ Crasso se refere depreciativamente aos estudos relativos à Latinitas. Ele afirma que, embora indispensável, trata-se de uma doctrina puerilis, de cognitio facilis. ${ }^{121}$ Segundo Hendrickson, seria em resposta a essas afirmações do De oratore que César teria escrito o seu De analogia. ${ }^{122}$ Mas se no De oratore a polêmica não pode ser defendida sem contestação, no Brutus ela é evidente.

No Brutus, Cícero atribui a virtude do Latine loqui a homens do chamado círculo de Cipião, como Lúcio Fúrio Filo (108), ${ }^{123}$ Públio Cipião (128) e Quinto Cátulo (132), oradores que teriam adquirido essa virtude pelo costume. Ecoando a afirmação de Crasso no De oratore, Cícero afirma no Brutus que a virtude do Latine loqui não é louvada pelo seu valor em si mas sim pela negligência dos oradores, uma vez que conhecer bem o latim não é tão louvável quanto é vergonhoso desconhecê-lo. ${ }^{124}$ No argumento de Cícero, falar bom latim não é algo que distingue o orador, mas sim algo próprio de qualquer cidadão, donde a distinção entre loqui e dicere. O que distingue o orador é a capacidade de ornamentar e embelezar o discurso, bem como mover os ânimos dos ouvintes.

No que concerne ao Latine loqui, César é o orador mais elegante. ${ }^{125}$ Através da personagem Ático, Cícero afirma que César esccreveu sobre o método de falar bom latim (de ratione Latine loqui 253), no qual César teria defendido que o fundamento da

\footnotetext{
${ }^{119}$ Ad Herenium IV. 12, 17: Latinitas est, quae sermonem purum conseruat, ab omni uitio remotum. Cf. HENDRICKSON (1906, p. 100).

${ }^{120}$ Noções devedoras de tradição peripatética. Cf. STroh (2010, p. 220).

${ }^{121}$ De oratore III, 38; 48.

${ }^{122}$ HENDRICKSON (1906, p. 115): "In view then of these considerations we shall be justified in concluding: (1) that the De analogia was elicited by certain utterances of Cicero's De oratore; (2) that it was written in the spring of the year 54 with the memory of Cicero's recent words fresh in the writer's mind; (3) that it was apparently rather a controversial pamphlet than a systematic treatise."

${ }^{123}$ Cf. Douglas (1966, p. 90).

${ }^{124}$ Brutus 140: [É que, por si só, falar bom latim é, de fato, como disse há pouco, algo a que se deve conferir o maior mérito, mas não tanto considerado em si mesmo, quanto porque é algo negligenciado pela maioria; com efeito, não é tão extraordinário saber latim quanto é vergonhoso não saber] nam ipsum Latine loqui est illud quidem [est], ut paulo ante dixi, in magna laude ponendum, sed non tam sua sponte quam quod est a plerisque neglectum: non enim tam praeclarum est scire Latine quam turpe nescire.

${ }^{125}$ Brutus 252.
} 
oratória seria uma elocução correta e em bom latim (locutionem emendatam et Latinam 258). Segundo a personagem Ático, essa obra de César teria sido dedicada a Cícero. A dedicatória aponta Cícero como principal interlocutor da obra, como resposta às críticas acerca da elementaridade e facilidade de se alcançar as virtudes oratórias do Latine loqui e da perspicuitas. ${ }^{126}$

Reportando o que seria uma "citação" do De analogia, ${ }^{127}$ a personagem Ático atribui as seguintes palavras a César:

ac si, cogitata praeclare eloqui ut possent, nonnulli studio et usu elaborauerunt, cuius te paene principem copiae atque inuentorem bene de nomine ac dignitate populi Romani meritum esse existumare debemus: hunc facilem et cotidianum nouisse sermonem nunc pro relicto est habendum?

[e se algumas pessoas pelo estudo e pela prática empenharam-se em dar expressão ilustre a seus pensamentos — devemos considerar que você, praticamente o expoente máximo e o inventor de tal riqueza, revelou-se digno do nome e do prestígio do povo romano - conhecer essa linguagem fácil e cotidiana é algo que agora deve se deixar de lado?] (Brutus 253)

Quanto à urbanitas, é interessante notar que, nessa mesma passagem do De oratore (III, 42), ao tratar da Latinitas, Cícero insere a distinção entre uma pronúncia ática e uma pronúncia asiática, para diferenciar, entre os latinos, os oradores que possuem uma pronúncia romana (vox Romani) dos que são tidos como estrangeiros (peregrini). ${ }^{128} \mathrm{~A}$ esse propósito, vale lembrar o relato de Cícero no Brutus a respeito de Teofrasto, que teria sido "descoberto" por uma velha feirante que havia percebido a pronúncia estrangeira do filósofo (Brutus 172). Nessa passagem, Cícero está respondendo ao questionamento de

\footnotetext{
${ }^{126}$ HendRICKSON (1906 b, p. 113): "The work was dedicated to Cicero, not because such a dedication would afford Caesar a desired opportunity to flatter the orator with exaggerated compliments, but because its theme was a vindication of the points of view which Cicero had dismissed so slightingly. The procedure was entirely analogous to Cicero's dedication of the two works in which he attacks the Atticists to Brutus, a partisan of the school attacked."

${ }^{127}$ Cf. HendRICKSON (1906 b, p. 114)

${ }^{128}$ Cf. De or. III, $42-44$.
} 
Bruto acerca do que ele, Cícero, chamou de matiz de urbanidade (urbanitatis color). Em resposta, Cícero parece irônico ao afirmar que não sabe dizer o que seria a urbanitatis color, mas que ela existe. A urbanitas seria uma espécie de costume vocabular e de pronúncia próprios da cidade de Roma. ${ }^{129}$ Ademais, quanto à pronúncia (sonus), Cícero estabelece correspondência entre a pronúncia urbana de Roma e a pronúncia característica da Ática. ${ }^{130}$

No Brutus, Cícero também aponta a imitatio antiquitatis como uma das características dos chamados "aticistas". ${ }^{131}$ Com efeito, nas duas passagens em que faz menção direta a eles, Cícero critica aqueles que se comprazem com o arcaismo entre os gregos e não o reconhecem em Catão, bem como aqueles que são demasiado arcaizantes ao escolherem como modelo Tucídides. ${ }^{132}$ Censurando esses "aticistas", Cícero afirma que o arcaismo não goza de tanto prestígio na oratória quanto nas artes da pintura e da escultura e que todas as artes seguem um curso de aprimoramento e sofisticação. ${ }^{133}$ Assim, entre os latinos, o gênero oratório de Catão, embora dotado de valor, teria sido superado pelo uso da estrutura periódica do discurso e pelo uso do ritmo oratório, ${ }^{134}$ assim como, entre os gregos, teria sido superada a oratória de Lísias, orador exemplar para os "aticistas".

\footnotetext{
${ }^{129}$ Brutus 171: ["O que você logo compreenderá, Bruto, quando chegar à Gália; também ouvirá certas palavras não usuais em Roma, mas elas podem ser mudadas e esquecidas; o mais importante é que na pronúncia de nossos oradores vibra e ressoa um tom mais urbano. $\mathrm{E}$ isso se manifesta não só nos oradores como também nos outros cidadãos."] id tu, Brute, iam intelleges, cum in Galliam ueneris; audies tu quidem etiam uerba quaedam non trita Romae, sed haec mutari dediscique possunt; illud est maius, quod in uocibus nostrorum oratorum retinnit quiddam et resonat urbanius. nec hoc in oratoribus modo apparet, sed etiam in ceteris.

${ }^{130}$ Brutus 172: [Desse modo, na minha opinião, há entre nós uma pronúncia peculiar aos oradores urbanos tal como, entre os gregos, aos áticos.] sic, ut opinor, in nostris est quidam urbanorum sicut illic Atticorum sonus.

${ }^{131}$ NARDUCCI (1997, p. 128): "Da Cicerone, il gusto atticistico viene più o meno esplicitamente tacciato di arcaismo."

${ }^{132}$ Brutus 67; 287.

${ }^{133}$ NARDUCCI (1997, p. 128): "come mostra una sua discussione sullo sviluppo della scultura greca (§70), egli aderisce a una dottrina, di origine ellenistica, secondo la quale l'evoluzione di tutte le arti muove in direzione della progressiva conquista della resa naturalistica e del superamento della 'durezza' arcaica; nell'orator ( $\S \S 168$ sgg.) una dottrina del genere verrà applicata anche al linguaggio: la conquista della 'naturalità' dell'espressione consiste nel modulare il ritmo della lingua in modo da assecondare l'andamento del pensiero; per questo un linguaggio che abbia superato l'acerbità delle origini si struttura in 'periodi' i quali ricercano spontaneamente la concinnitas, la simetria dei suoni e delle cadenze."

${ }^{134}$ NARDUCCI (1997, p. 137): "l'oratoria catoniana gli [Cicerone] appare 'ruvida' e, soprattutto per quanto riguarda la costruzione del periodo e la composizione, priva di quel raffinamento che sarebbe stato dovuto all'attività di generazioni successive. Oratore grande per il suo tempo, Catone risulta pertanto improponibile all'epoca attuale."
} 
Segundo Cícero, os "aticistas" também procuravam imitar Tucídides (Brutus 287). Além de censurá-los pelo fato de escolherem um historiador como modelo para a oratória, ${ }^{135}$ Cícero os repreende por escolherem um modelo demasiado arcaico, comparando-o a um vinho muito envelhecido. ${ }^{136}$

\section{Dois gêneros de eloquência}

Na história da oratória romana apresentada no Brutus, distinguem-se dois gêneros oratórios: o genus tenue e o genus grave. A nomenclatura é variada, mas mantém-se a dicotomia. O primeiro também é chamado breve, pressum, subtile. O segundo também é chamado copiosum, ornatum, amplum. O genus tenue é caracterizado como discurso sóbrio, breve e conciso, que evita a ornamentação e o recurso ao patético. O genus grave é caracterizado como discurso ornamentado, copioso, espirituoso, que recorre ao patético para atingir a persuasão. ${ }^{137}$ Nas palavras de Cícero,

[Portanto, uma vez que há dois tipos de bons oradores — e são esses que procuramos - , um dos que discursam de modo plano e conciso, o outro, de modo elevado e copioso, embora seja o melhor aquele que é mais brilhante e mais magnífico; no caso do que é bom, tudo aquilo que atinge a perfeição merece elogio.]

quoniam ergo oratorum bonorum - hos enim quaerimus — duo genera sunt,

\footnotetext{
${ }^{135}$ Cf. Brutus 287 e Orator 30.

${ }^{136}$ Brutus 288: [Desta maneira, a esses eu aconselharia que tanto evitassem essa nova eloquência ainda em fermentação, como que um vinho mosto e em conservação, como também não procurassem a notável eloquência de Tucídides demasiado antiga tal como uma ânfora do ano de Anício.] sic ego istis censuerim et nouam istam quasi de musto ac lacu feruidam orationem fugiendam nec illam praeclaram Thucydidi nimis ueterem tamquam Anicianam notam persequendam.

${ }^{137}$ NARDUCCI (1997, p. 114): "Uno degli assunti critici fondamentali del Brutus è che esistono, sostanzialmente, due tipi di oratore: quello di stile «piano», che privilegia una esposizione pacata e concisa, nelle scelte stilistiche si lascia guidare dal criterio di un'eleganza sobria e controllata, e sembra inibirsi l'appello alle passioni; e quello dallo stile «grandioso», che aspira a un fortissimo impatto emozionale sull'uditorio, e per questo fa ampio ricorso all'ornamentazione retorico-patetica." MARCHESE (2011, p. 34): "In sostanza, da una parte Cicerone individua uno stile 'piano', caratterizzato da pacatezza, brevità, controllo espressivo, scarso ricorso alle figure, rifiuto dell'appello alle passioni e alle emozioni dell'ascoltatore; dall'altra uno stile 'grandioso', che invecce fa ampio ricorso alle sollecitazioni emotive, che è tutto punteggiato di ornamenti retorici in grado di attirare l'atenzione e il consenso degli ascoltatori."
} 
unum attenuate presseque, alterum sublate ampleque dicentium, etsi id melius est quod splendidius et magnificentius, tamen in bonis omnia quae summa sunt iure laudantur. (Brutus 201)

Entre esses dois gêneros oratórios, Cícero demonstra maior apreço pelo genus grave. Ele apresenta essa dicotomia a fim de argumentar que o recurso ao patético e à ornamentação são fundamentais para uma oratória mais completa e mais persuasiva. No Brutus, o "confronto" entre um gênero plano e um gênero elevado repercute a polêmica de Cícero com os "aticistas". ${ }^{138}$ Ao longo do diálogo, Cícero argumenta no sentido de procurar exemplificar essa oposição.

Assim, relatando uma causa defendida por Lélio e Galba, Cícero apresenta a oratória de Lélio como sendo mais elegante, enquanto a de Galba é mais enérgica. Segundo Cícero, Lélio teria discursado em favor dos publicanos duas vezes e, em seguida, teria sugerido a eles que a causa fosse entregue a Galba, que seria capaz de discursar de modo mais severo e mais veemente (Brutus 86). No primeiro, o genus tenue favorece o docere; no segundo, a gravitas favorece o movere. ${ }^{139}$ Outro exemplo do "confronto" dos dois gêneros de eloquência é o processo no qual disputaram Crasso e Cévola, a chamada causa Curiana (Brutus 194-198). Nesse processo sobre herança em que Cévola é acusador e Crasso defensor, Cícero opõe o discurso breve e conciso de Cévola ao discurso copioso, variado e

\footnotetext{
${ }^{138}$ NARDUCCI (1997, p. 114): "Le preferenze di Cicerone vanno, ovviamente, all'oratore del secondo tipo, $\mathrm{o}$, per essere più esatti, a un oratore che, capace di spaziare con sovrana padronanza tra i più diversi registri di stile, sia consapevole che in molte occasioni solo il ricorso al registro «grandioso» gli permetterà di operare, tramite una persuasione vittoriosa, la «conquista» definitiva dei suoi ascoltatori (egli stesso era convinto di impersonare un tale modelo di oratore); d'altra parte l'eloquenza controllata, di stile «piano», era prediletta dagli atticisti, i quali rappresentano, nel nostro dialogo, un bersaglio polemico non sempre dichiarato, ma raramente perduto di vista." MARChese (2011, p. 35): "Non va quindi dimenticato che la distinzione tra i due stili dell'eloquenza, la preferenza per un'oratoria in grado di variare i diversi registri espressivi e sostanzialmente finalizzata a realizzare con efficacia le persuasione del pubblico, sono proprio gli stessi elementi chi sostengono Cicerone nella sua polemica nei confronti del cosiddetto 'atticismo'."

${ }^{139}$ Brutus 89: [como são duas as principais qualidades do orador, a primeira, expor minuciosamente o que se deve instruir, a segunda, atuar com veemência para comover os ânimos dos ouvintes, e obtém muito mais êxito aquele que inflama o juiz do que aquele que instrui, havia elegância em Lélio, vigor em Galba.] cum duae summae sint in oratore laudes, una subtiliter disputandi ad docendum, altera grauiter agendi ad animos audientium permouendos, multoque plus proficiat is qui inflammet iudicem quam ille qui doceat, elegantiam in Laelio, uim in Galba fuisse.
} 
espirituoso de Crasso (Brutus 198). ${ }^{140}$

\section{Cícero e Licínio Calvo: o cerne da polêmica}

Segundo Cícero, o orador que se professava "ático" era Caio Licínio Calvo (Brutus 284). Mais jovem e morto prematuramente, ${ }^{141}$ Calvo parece ter desempenhado um papel de "liderança" na oposição ao gênero oratório copioso e ornado de Cícero, pois, nas palavras deste, ele não só se enganava como também fazia com que outros se enganassem (Brutus 284). Segundo o velho Sêneca, Calvo teria disputado com Cícero o primado da eloquência. ${ }^{142}$ Como já mencionamos, Tácito e Quintiliano deram testemunho da controvérsia entre Calvo e Cícero. ${ }^{143}$ A partir da contraposição ao gênero oratório praticado por Calvo, Cícero procura mostar quais seriam os equívocos e exageros dos "aticistas" e apresentar uma imagem de sua própria oratória. Podemos dizer que, juntamente com Hortênsio, Calvo desempenha um papel preponderante na estratégia do Brutus de construção da persona Ciceronis, pois Cícero se opõe tanto ao asianismo de Hortênsio como ao "aticismo" de Calvo. ${ }^{144}$

Podemos dizer que, a partir da distinção dos dois genera dicendi, a oratória de Calvo se enquadra no genus tenue. Cícero caracteriza o discurso de Calvo como excessivamente meticuloso, adequado à aprovação de um público cultivado, mas não à aprovação da multidão e aos tribunais. ${ }^{145}$ Essa meticulosidade, segundo Cícero, fazia com que o discurso

\footnotetext{
${ }^{140}$ Podemos dizer que o próprio Cícero também aparece como exemplo da oposição entre os dois gêneros oratórios, como no caso do processo contra Marco Calídio (Brutus 274-77). Ao acusar Quinto Galo de atentar contra sua vida, Calídio pronunciou um discurso minucioso e bem elaborado, mas não inflamou os ânimos dos ouvintes. Cícero, então, se valeu dessa falta de vigor do discurso de Calídio na defesa bem sucedida de seu cliente (278).

${ }^{141}$ Há controvérsia a respeito da data de sua morte. Os estudiosos colocam-na entre 54 e 47 a. C. Cf. NARDUCCI (1997, p. 129)

${ }^{142}$ Contr. VII 4, 6: "Calvus, qui diu cum Cicerone iniquissimam litem de principatu eloquentiae habuit."

${ }^{143}$ Dialogus 18,5 e Inst. Or. XII, 10, 12.

${ }^{144}$ DugAn (2005, p. 214): "The way Cicero presents himself in the Brutus as part of an unbalanced triptych portrait - first a sketch of Calvus, then the interruption of Atticus' complaint against Cicero's sincerity, and finally the meditaion upon Hortensius that bleeds into one of Cicero - establishes a dialectical understanding of Cicero's self between the excesses of Atticism and Asianism exemplified by Calvus and Hortensius respectively."

${ }^{145}$ Brutus 283 "Por isso, seu discurso, empobrecido pelo excesso de minúcia, era claro para os doutos e para os ouvintes atentos, mas era mal digerido pela multidão e pelo fórum, para os quais nasceu a
} 
de Calvo se tornasse exangue (sanguinem deperdebat), sem vitalidade. Cícero afirma que aqueles que professam imitar os oradores áticos imitam apenas os ossos (ossa), mas não o sangue (sanguis). ${ }^{146}$

Cícero estabelece uma metáfora entre o gênero oratório de Calvo e dos "aticistas" com a linguagem do corpo. ${ }^{147}$ É a constituição física do gênero oratório vai revelar sua saúde ou sua debilidade. Para os "aticistas", a sanidade (sanitas) do discurso é a ieiunitas, a siccitas e a inopia (284-5). No entanto, para Cícero, esses são sintomas de debilidade do discurso. Segundo Dugan, "Cícero traça a genealogia do aticismo, desde seu nascimento em Atenas até seus autodenominados sucessores romanos, como um declínio da robustez ateniense para a anorexia romana." 148

De fato, Cícero afirma que até o período da oratória grega que abarca a geração de Hipérides, Ésquines, Licurgo, Dinarco e Demades, a eloquência ática ainda mantinha sua vitalidade e sua pureza de sangue (sucus ille et sanguis incorruptus 36). Depois que a eloquência deixou o Pireu e percorreu toda a Ásia, ela perdeu sua salubridade (salubritas) e sua sanidade (sanitas) de antes (51). No De optimo genere oratorum, Cícero repete a metáfora, novamente se referindo à oratória de Calvo e dos "aticistas": eles possuem uma boa saúde, mas aquela saúde de atletas amadores, não de campeões olímpicos. Os campeões não se contentam com ter uma boa saúde, mas também procuram a força (vires), músculos (lacertos) e vitalidade (sanguinem). ${ }^{149}$

No entanto, essa é a opinião e a voz do próprio Cícero, e não dispomos dos discursos de Calvo para avaliar esse julgamento. O que não quer dizer que a oratória de Calvo fosse totalmente desprovida de vigor (vis). Narducci ressalta que "numerosos testemunhos

eloquência." itaque eius oratio nimia religione attenuata doctis et attente audientibus erat inlustris, multitudine autem et a foro, cui nata eloquentia est, deuorabatur.

${ }^{146}$ Brutus 68.

${ }^{147}$ Dugan (2005, p. 216): "Throughout his description of Calvus' oratory Cicero uses the language of the body, which anticipates Cicero's account of his own style and his self in bodily terms."

${ }^{148}$ Dugan (2005, p. 217): "Cicero traces Atticism's genealogy from its birth in Athens to its selfproclaimed Roman heirs as one of a decline from Athenian robustness to Roman anorexia."

${ }^{149}$ De optimo genere oratorum 8: Sed quatenus valuerunt, sani et sicci dumtaxat habeantur, sed ita ut palaestritae; spatiari in xysto ut liceat, non ab Olympiis coronam petant. Qui, cum careant omni vitio, non sunt contenti quasi bona valetudine, sed viris, lacertos, sanguinem quaerunt, quandam etiam suavitatem coloris, eos imitemur si possumus. 
antigos insistem sobre o grande sucesso que Calvo alcançava, e, em particular, sobre sua actio violenta e exaltada e sobre a eficácia em inflamar a emoção do público." ${ }^{150}$ A atividade de Calvo como poeta de orientação calimaquiana poderia explicar a exilitas de seu discurso oratório, que apesar disso não renunciava suscitar a emoção do público. ${ }^{151}$ Ademais, também há testemunhos antigos que sustentam uma aproximação entre Calvo e Demóstenes. ${ }^{152}$ É o que fazem o velho Sêneca numa passagem das Controversiae e o jovem Plínio numa de suas cartas. ${ }^{153}$ Quintiliano inclusive atesta a veemência do discurso de Calvo. ${ }^{154}$ Narducci sugere que o que motivaria o dissenso entre Calvo e Cícero seria o modo diverso de conceber o vigor (vis) de Demóstenes. Cícero teria privilegiado a copiosidade, enquanto Calvo teria privilegiado a densidade da expressão. ${ }^{155}$

Por um lado, em sua crítica aos "aticistas", Cícero procura redefinir o "aticismo", quando afirma que não há um gênero "ático" único (nec enim est unum genus 285). Lísias e Tucídides não podem ser tomados como únicos modelos. Devem ser considerados oradores áticos e devem ser imitados Péricles, Hipérides, Ésquines e Demóstenes (290). ${ }^{156}$ Por

\footnotetext{
${ }^{150}$ NARDUCCI (1997, p. 130): "numerose testimonianze antiche — che qui non mette conto ricordare insistono sul vasto successo che Calvo riscuuteva, e, in particolare, sulla actio violenta e concitata e sulla sua efficacia nell'accendere le emozioni del pubblico."

${ }^{151}$ NARDUCCI (1997, p. 130): "La ricerca dello stile piano, l'alto valore assegnato alla pureza della dizione, la raffinata sensibilità per la scelta delle parole e il ripudio delle amplificazioni, non significavano necessariamente la rinuncia a provocare le emozoni del pubblico."

${ }^{152} \mathrm{Stroh}(2010$, p. 324): "Calvus fut presque considéré comme un nouveau Démosthène et sa réussite fut importante." NARDUCCI (1997, p. 131): "le caratteristiche che avvicinano Calvo a Demostene sono concordemente sottolineatti da alcune fonti antiche."

${ }^{153}$ Contr. VII 4, 8: "compositio quoque eius [Calvus] in actionibus ad exemplum Demosthenis viget", e Ep. I, 2, 2: "Temptavi enim imitari Demosthenen semper tuum, Calvum nuper meum, dumtaxat figuris orationis."

${ }^{154}$ Inst. Or. X 1, 115: "inveni qui Calvum praeferrent omnibus, inveni qui Ciceroni crederent eum nimia contra se calumnia verum sanguinem perdidisse; sed est et sancta et gravis oratio et castigata et frequenter vehemens quoque."

${ }^{155}$ NARDUCCI (1997, p. 132): "Queste diverse indicazioni sembrano convergere nel suggerire la possibilità che una delle principali ragioni del dissenso tra Calvo e Cicerone consistesse nella diversa maniera di rendere la vis demostenica: Cicerone privilegiava la copia, l'amplitudo magniloquente, Calvo una densitas, una concentrata intensità d'espressione in cui l'autore del Brutus vedeva solo una monotona exilitas, 'incapacità di raggiungere, quando necessario, le vette del pathos grandioso. Se queste considerazioni colgono nel vero, sembra di poter affermare che, quale che ne fosse l'impatto sul pubblico, l'imitazione di Demostene praticata da Calvo e dai suoi seguaci aveva, per così dire, buone giustificazioni «filologiche»."

${ }^{156}$ NARDUCCI (1997, p. 127): "Nel Brutus, la risposta di Cicerone ai suoi critici muove da una ridefinizione dello stesso concetto di stile «attico», che insiste sulla varietà dei toni e dei livelli stilistici: l'eccellenza non si trova solo nello stile smagrito di Lisia o in quello disarticolato di Tucidide; insistendo sull'idea che l'eloquenza attica si definisce anche per la vis, lo splendore e l'abbondanza, egli asserisce che il modello deve essere piuttosto ricercato nell'oratore più grande e più vario, cioè in Demostene, l'unico che abbia saputo pienamente padroneggiare tutti i diversi generi e registri dell'espressione ( $\S 35,66$ sgg., 285)."
} 
outro lado, em sua resposta à imputação de "asianismo", Cícero procura se contrapor ao genus asiaticum praticado por Hortênsio.

\section{Genus Asiaticum: Hortênsio e Cícero}

Depois de apresentar a oratória de Calvo, Cícero apresenta a oratória de Hortênsio. São esses os dois principais oradores aos quais Cícero se contrapõe: o primeiro, "lider" dos "aticistas", o segundo, como que um dandy do "asianismo". Entre os excessos de ambos, Cícero parece procurar a mediania. ${ }^{157}$

Já no prólogo do Brutus, Hortênsio é apresentado como amigo e rival de Cícero (1 amicus e adversarius 3). Ao final do diálogo, a oratória de Hortênsio é apresentada paralelamente à oratória de Cícero. Hortênsio começou muito jovem, quando ainda discursavam Antônio e Crasso, e fez parte da geração de Cota e Sulpício, da geração de Cícero, bem como da geração de Bruto e Calvo. Com efeito, Cícero afirma ter seguido os passo de Hortênsio (Brutus 307) e relata que os dois melhores oradores a serem imitados eram Cota e Hortênsio. ${ }^{158}$ Ressalta sua laboriosidade para tomar o primado da eloquência das mãos de Hortênsio, que por sua própria negligência teria deixado sua eloquência enfraquecer e perder o brilho, e relata a Bruto que a oratória de Hortênsio que ele conheceu já havia perdido o antigo viço (317). São duas as censuras que Cícero faz a Hortênsio: ter negligenciado os exercícios oratórios que praticara com afinco e não ter modificado o gênero asiático que praticava em sua juventude. ${ }^{159}$ Cícero distingue dois gêneros de "asianismo": um, sentencioso e penetrante, o outro, impetuoso e veloz (325). Hortênsio se sobressaía em ambos. No entanto, esses gêneros oratórios são mais apropriados aos jovens,

\footnotetext{
${ }^{157}$ DugAn (2005, p. 215): "Ciceronian copia and ornatus thus take the form of a peripatetic mean between the Asianist and Atticist extremes embodied in these two orators."

${ }^{158} \mathrm{O}$ primeiro pode ser enquadrado no genus tenue, o segundo no genus grave. DUGAN (2005, p. 223): "The contrast between Cotta and Hortensius plays out a dichotomy similar to that we have already seen between Atticism and Asianism."

${ }^{159}$ DugAN (2005, p. 221): "Cicero's analysis of Hortensius' decline pinpoints two particular areas where the orator was at fault: allowing his talents to become diminished by relaxing his formerly enthusiastic training regimen; and retaining his Asianist style of speaking throughout his career, even when, as an older man, such a style was inappropriate."
} 
não são tão apropriados à idade madura (326).

Ao contrário de Hortênsio, Cícero não teria abandonado a laboriosidade nem deixado de modificar seu genus dicendi. Se Hortênsio é criticado por sua negligência, Cícero não poupa esforços em mostrar sua laboriosidade. ${ }^{160}$ Quanto ao "asianismo", Cícero pretende mostrar que a instrução que recebeu na Ásia foi aquela mais próxima da Ática. Rodes aparece como o lugar do oradores asiáticos mais sóbrios e mais parecidos com os áticos (Brutus 51). A partir do treinamento com o rétor Apolônio Mólon de Rodes, Cícero reformula seu discurso, e seu corpo ganha nova constituição física (316). A justificativa dada por Cícero para sua viagem à Ásia é a de que precisava diminuir a intensidade da voz e modificar seu gênero oratório, em razão de sua saúde comprometida pela prática oratória e por sua constituição física. Nas palavras do próprio Cícero:

[Eu tinha, naquela época, um corpo extremamente magro e fraco, um pescoço alongado e delgado, com esse aspecto e com essa aparência estima-se não estar muito longe de um risco de vida, se ainda se acrescenta a fadiga e o esforço extremo dos pulmões. Isso preocupava ainda mais aqueles que me tinham em boa conta, porque eu conduzia todo meu discurso sem diminuir a intensidade, sem variar o tom, com extrema força na voz e tensão em todo corpo. [314] Por isso, embora meus amigos e os médicos me aconselhassem a desistir de atuar como orador, eu considerava preferível enfrentar qualquer perigo a abandonar a desejada glória oratória. Mas como eu julgava que com a diminuição da intensidade, a moderação da voz e a mudança do gênero oratório eu poderia evitar o perigo e discursar com mais equilíbrio, a mudança em meu modo de discursar foi a causa de minha partida para a Ásia. $]^{161}$

\footnotetext{
${ }^{160}$ DugAn (2005, p. 225): "After providing the vivid image of Hortensius' decline as a fading painting, such that he because he slackened his former industry, seemed 'day-by-day more unlike himself', Cicero explicitly presents himself as a contrasting paradigm of hard work."

${ }^{161}$ Brutus 313-4: "erat eo tempore in nobis summa gracilitas et infirmitas corporis, procerum et tenue collum: qui habitus et quae figura non procul abesse putatur a uitae periculo, si accedit labor et laterum magna contentio. eoque magis hoc eos quibus eram carus commouebat, quod omnia sine remissione, sine uarietate, ui summa uocis et totius corporis contentione dicebam. (314) Itaque cum me et amici et medici hortarentur ut causas agere desisterem, quoduis potius periculum mihi adeundum quam a sperata dicendi
} 
Quanto ao "asianismo", Cícero procura se esquivar das acusações, seja afirmando que fizera parte de sua oratória juvenil, seja defendendo a moderação de um gênero ornamentado e copioso. Cícero admite a divisão entre os gêneros "ático" e "asiático" e compartilha também os valores atribuídos a cada um deles, mas procura mostrar que não é um "asiático" e que seus adversários não são áticos. ${ }^{162}$

gloria discedendum putaui. sed cum censerem remissione et moderatione uocis et commutato genere dicendi me et periculum uitare posse et temperatius dicere, ut consuetudinem dicendi mutarem, ea causa mihi in Asiam proficiscendi fuit."

${ }^{162}$ Stroh (2010, p. 325): "L'idée centrale de Cicéron dans cette discussion, c'est qu'il admet tout à fait la distinction que ses contradicteurs font entre «attique» et «asiatique», et qu'il partage même leur jugement quant à la valeur relative des deux styles (il n'a jamais pris position là-dessus avant), mais il essaye de montrer premièrement, que lui-même n'est pas un «asiate» et que deuxièmement, ses adversaires ne sont pas des «attiques». Brutus défend essentiellement le premier point, Orator le second." 


\section{Sobre a memoria e o scriptum}

Neste capítulo, analisaremos a temática do texto escrito no Brutus. No primeiro momento, abordaremos o tema da memoria e de seu correlato, o monumentum. Em seguida, trataremos do tema da escrita no Brutus enquanto dimensão "privada" da eloquentia.

\section{Memoria et recordatio}

O diálogo Fedro de Platão, que Cícero provavelmente conhecia diretamente, aborda, entre

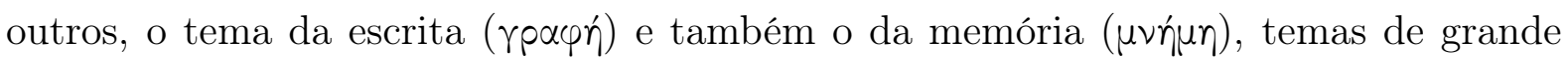
relevância no Brutus. Numa rua de Atenas, Sócrates encontra Fedro, que vinha da casa de Lísias e que pretendia fazer uma caminhada fora dos muros da cidade. Fedro afirma ter ouvido um discurso de Lísias sobre o amor. Sócrates percebe que Fedro traz o discurso escondido consigo. Fedro, então, lamenta ter perdido a oportunidade de exercitar sua memória recitando o discurso para Sócrates, que prefere lê-lo, pois seria como ouvir o próprio Lísias. Sócrates e Fedro encontram um lugar junto ao regato do Ilisso para ler o discurso e continuar a conversa. Fedro, então, lê o discurso de Lísias, Sócrates faz a crítica desse discurso e, exortado por Fedro, profere, ex tempore, um primeiro discurso sobre o amor. Em seguida, faz um segundo discurso, como uma palinódia ao primeiro, explorando diversos pontos da doutrina platônica. Ao final do diálogo, Sócrates apresenta um mito egípcio sobre a invenção da escrita.

O deus egípcio Thot teria apresentado ao deus que governava o Egito, Tamuz, algumas artes que tinha inventado, entre elas, a escrita ( үрá $\mu \mu \alpha \tau \alpha)$. Thot apresenta essa invenção 
como algo que traria mais instrução aos egípcios e maior capacidade mnemônica, um

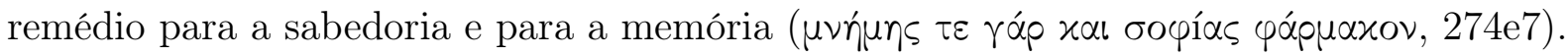
Tamuz, pelo contrário, afirma que, confiando na escrita, eles deixarão de exercitar a memória e suas almas se tornarão esquecidas, a escrita não seria um remédio da memória

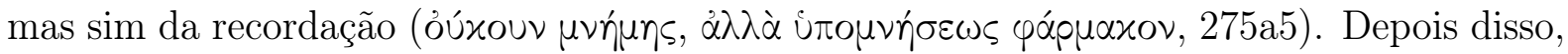
Sócrates e Fedro encerram o diálogo discutindo sobre as condições de legitimidade da escrita. Do ponto de vista da doutrina platônica, a escrita, tal como a pintura, é um simulacro, uma imagem ( forma imperfeita de representação da realidade, ela tem seu valor quando acompanhada do

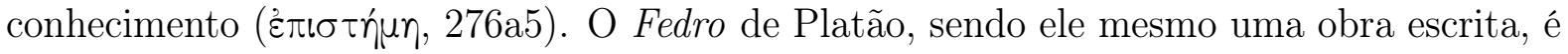
tido como fundador de uma tradição de hostilidade em relação ao texto escrito. ${ }^{164}$ Ao contrário de uma hostilidade em relação à escrita, o Brutus faz, por assim dizer, um elogio dela. No Brutus, a escrita é o portador da memoria.

No Brutus, o termo memoria muitas vezes guarda o sentido de historia (memoria rerum), de tradição (memoriae proditum est), de capacidade de recordar, isto é, faculdade do ânimo (pars animi), e também de parte da retórica. A memoria enquanto historia e tradição está vinculada diretamente à forma escrita. No sentido de pars animi e de técnica retórica, o vinculo com a escrita não é tão evidente.

\section{Memoria enquanto pars animi}

No Brutus, o termo memoria, por vezes, é usado no sentido de parte do ânimo (219). Memoria é também uma das cinco partes da retórica (215). ${ }^{165}$ Ou seja, a memoria é uma capacidade natural que pode ser aperfeiçoada pela técnica. ${ }^{166} \mathrm{Na}$ segunda metade do diálogo, a partir da geração de Antônio e Crasso, Cícero passa a mencionar oradores que ele mesmo conheceu. Sobre alguns desses oradores, Cícero faz considerações mais

\footnotetext{
${ }^{163}$ Cf. também Carta VII 342a7-344d3.

${ }^{164}$ Cf. Gowing (2000, p. 43) e Fairweather (1981, p. 42).

${ }^{165}$ Segundo a tradição seguida por Cícero, a retórica é constituída de cinco partes. Cf. Brutus 25; Inv. I, VII, 9; De or. I, 142-3.

${ }^{166}$ Nos Academica priora (2), Cícero usa o termo ars memoriae.
} 
técnicas acerca de suas qualidades oratórias, partindo da divisão da retórica em cinco partes: uns são bons na inventio, outros são melhores na dispositio, alguns são superiores na elocutio, outros dominam a actio, seja em razão da capacidade natural (natura), seja como resultado da técnica (ars), seja enquanto fruto do treinamento (exercitatio). ${ }^{167}$

No que diz respeito à memoria, tomemos primeiramente o exemplo de Curião. Na verdade, trata-se de um contraexemplo, pois Cícero vitupera Curião por sua falta de memória (oblivio). Como se não bastasse a falta de memória de Curião ao discursar de improviso (ex tempore) e ao dizer, por exemplo, que iria expor três pontos e desenvolver quatro, ou quando se esquecia do terceiro (217), o que Cícero apresenta como ainda mais torpe é o fato de ter esquecido algo que ele mesmo havia escrito. Curião teria escrito um livro em forma de diálogo em que representava uma conversa entre ele, o seu filho e Pansa. ${ }^{168}$ A crítica de Cícero é que a conversa se inicia ao fim de uma sessão do senado presidida pelo cônsul César, e Curião critica a atuação de César como governador da Gália, o que só teria acontecido no ano seguinte, constituindo um problema de anacronismo (218). O grande absurdo é que esse esquecimento se deu em um texto escrito (tantamne fuisse oblivionem in scripto praesertim 219). O vitupério incide sobre o ingenium de Curião, revelando sua debilidade. Por outro lado, exemplo de grande capacidade mnemônica é Hortênsio. Segundo Cícero, Hortênsio tinha uma memoria tão excelente, que ele era capaz de lembrar, sem auxílio de anotações, de tudo aquilo que seus adversários haviam dito (301). Além de possuir um ingenium privilegiado, Hortênsio o aprimorava pelo treinamento constante (303).

Também podemos pensar na memoria do próprio Cícero enquanto personagem no Brutus. Na ficção do diálogo, a persona auctoris apresenta o sermo como memoria et recordatio de cidadãos bem afortunados que viveram sob a república. Podemos distinguir nessa passagem dois sentidos de memoria et recordatio. Por um lado, trata-se de uma recordação de tempos passados, ou seja, da história romana e de cidadãos ilustres como

\footnotetext{
${ }^{167}$ Cícero, por exemplo, comenta a oratória de Antônio a partir da divisão em cinco partes da retórica, bem como afirma que tais qualidade não eram provenientes da ars (Brutus 139-141). Para Cícero, são três os modos de se sobressair na oratória: natura, exercitatio e ars (Brutus 25).

${ }^{168}$ Cf. NARDUCCI $(1995$, p. 284$)$
} 
Catão, Cipião, Lélio, Rutílio Rufo, Antônio, Crasso etc.; por outro lado, o diálogo é a recordação de uma conversa de Cícero com seus amigos Ático e Bruto (Brutus 9). A persona auctoris descreve para o leitor a sua lembrança da conversa. Nesse segundo sentido, trata-se de um lugar comum poético-retórico. No Brutus, Cícero é personagem do sermo e seu relato é uma recordação de uma situação, segundo a verossimilhança, vivida pelo próprio Cícero. Nos Academica, Cícero também é personagem do sermo. Em sua primeira versão, as personagens são Luculo, Cátulo, Hortênsio e o próprio Cícero, que não toma parte da discussão, mas sua presença pode ser entendida como testemunha da conversa. Já no De oratore e no De republica ele é apenas persona auctoris. Segundo outro verossímil, o relato de Cícero nesse caso é uma recordação do que ele teria ouvido dos relatos de Cévola e Rutílio Rufo, que, por sua vez, teriam testemunhado as conversas "originais" do De oratore e do De republica.

Encontramos essa mesma tópica em alguns diálogos de Platão. Por exemplo, no Fédon, no Banquete, no Parmênides, os diálogos são relatos de pessoas que teriam ouvido os relatos de outras pessoas que teriam presenciado essas conversas. É interessante o caso do diálogo Teeteto sob a perspectiva da memória e da escrita. Euclides teria ouvido de Teeteto o relato de sua conversa com Sócrates. Euclides memorizou o relato de Teeteto e escreveu o que foi capaz de lembrar. Do que não foi capaz de lembrar, nas oportunidades que teve de interrogar Sócrates acerca dessa conversa, Euclides completou suas anotações, de modo que ele possuía quase toda a conversa por escrito. O diálogo Teeteto é a leitura dessas anotações de Euclides. Entre os latinos, notamos o mesmo lugar-comum no Dialogus de Tácito e nas Declamationes do velho Sêneca. A persona auctoris do Dialogus, respondendo à demanda de seu amigo Fábio Justo sobre a razão de os tempos atuais não produzirem tão bons oradores quanto os tempos passados produziram, afirma que, a partir de sua memoria et recordatio, vai relatar a conversa que ouviu de Curiato Materno, Marcos Áper, Júlio Secundo e Messala Corvino a esse respeito. Em suas Declamationes, o velho Sêneca, atendendo ao pedido de seus filhos, que querem ouvir as sententiae dos antigos declamadores, afirma que vai recorrer à sua memoria, que já foi brilhante mas 
está debilitada pela velhice, para reunir as sentenças dos declamadores.

É interessante notar que a memoria entendida como faculdade da alma é também concebida como um lugar comum do gênero dialógico e inclusive de outros gêneros, como no caso das Declamationes. Nesse sentido, memoria enquanto parte do ânimo é uma faculdade individual que através da escrita pode se tornar uma memoria compartilhada, coletiva, transmitida em forma de monumentum.

\section{Memoria e monumentum}

Segundo o Dictionnaire Etymologique de la Langue Latine, o termo monumentum deriva de moneo, que quer dizer "fazer pensar, lembrar". Monumentum "é tudo aquilo que traz a memória, e particularmente aquilo que traz a memória de um morto, túmulo ( $\mu \nu \tilde{\eta} \mu \alpha)$, estátua, inscrição(ões) etc."169 Memoria é o substantivo correspondente do verbo memini e deriva de memor, cujo primeiro sentido é "ter presente na mente, rememorar". ${ }^{170}$ A relação entre memoria e monumentum, isto é, entre memória e escrita, é um tema central no Brutus. ${ }^{171}$ O Brutus é um monumentum que dialoga com diversos outros monumenta. São monumenta os discursos, as obras historiográficas, os documentos públicos e privados (annales, commentarii) e também os poemas. Como que dialogando com esses escritos, Cícero erige um monumentum à oratória republicana.

Começando pelos oradores gregos, Cícero afirma que Atenas foi a "cidade onde pela primeira vez a oratória passou a ser confiada aos registros históricos e aos escritos". ${ }^{172}$ Antes de Péricles e Tucídides não há nenhum escrito (littera) que testemunhe a existência de um verdadeiro orador, embora se acredite que Pisístrato, Sólon e Clístenes tivessem grande valor na oratória. ${ }^{173}$ Com relação àqueles que não deixaram nada escrito, Cícero se vale

\footnotetext{
${ }^{169}$ Ernout et Meillet (1951, s. v. moneo): "Monumentum (moni-) est tout ce qui rappelle le souvenir (...) et particulièrement ce qui rappelle le souvenir d'un mort: tombeau ( $\mu \nu \tilde{n} \mu \alpha)$, statue, inscription(s), etc."

${ }^{170} \mathrm{Cf}$. ERnout et Meillet (1951, s. v. memor).

${ }^{171}$ Gowing (2000, p. 44): "In short, Cicero forges a clear link between writing and memory".

172 qua in urbe (...) primumque etiam monumentis et litteris oratio est coepta mandari 26.

${ }^{173}$ Como se sabe, alguns discursos de Péricles são reportados por Tucídides em sua História da Guerra do Peloponeso. Também oferece um testemunho da oratória de Péricles o comediógrafo Êpolis (Brutus $38,59)$.
} 
dos testemunhos de outros autores para fazer alguma consideração acerca das qualidades desses que nada escreveram. A partir dos registros de Ático (ex Attici monumentis), Cícero afirma que Temístocles se sobressaía na eloquência, bem como Cleão (28). A partir dos escritos de Tucídides, é possível depreender qual o gênero oratório (dicendi genus) que vigorava na época de Alcibíades, Crítias e Teramenes (29). Na época posterior, foram escritores prolíficos Isócrates (32), Lísias (35) e Demóstenes (35). Também escreveram discursos Hipérides, Ésquines, Licurgo e Dinarco (36). Demades, porém, não deixou nada escrito.

Sobre os primórdios da república, só é possível fazer conjeturas com base nos registros da história romana (ex monumentis suspicari 52), pois não há discursos nem referências da oratória desse período. Assim, Lúcio Bruto, lendário fundador da república, deveria ter um discurso persuasivo para ter obtido suas conquistas (oratione persuasum 53). A partir dos monumenta, é possível conjeturar que Marco Valério, na qualidade de ditador, aplacou a primeira discórdia entre patrícios e plebeus, que resultou na criação do tribunado da plebe ${ }^{174}$ com a palavra (dicendo 54). Cícero também atribui certa capacidade oratória a Lúcio Valério Potito, Ápio Cego, Caio Fabrício, Tibério Coruncano, Mânio Cúrio e outros importantes personagens da história romana. "Mas que eles fossem considerados oradores ou então que, de modo geral, houvesse alguma recompensa para a eloquência, acredito não ter lido realmente nada sobre isso: o que me faz suspeitar é apenas uma conjectura", ${ }^{175}$ afirma Cícero. O fato é que o Brutus também se constitui como um monumentum à memoria desses homens.

O primeiro testemunho da destreza de um orador romano é dado por Ênio sobre a habilidade de Marco Cornélio Cetego (57), chamado de "esplendor do povo", "alma da Persuasão" (flos populi, Suadai medulla 59). Ao comentar o testemunho de Ênio, Cícero afirma a importância do texto escrito para a preservação da memória, pois "se isso não tivesse sido conhecido pelo testemunho único de Ênio, o passar do tempo, como

\footnotetext{
${ }^{174}$ Cf. Tito Lívio II, 33.

${ }^{175}$ Brutus 56: "sed eos oratores habitos essent aut omnino tum ullum eloquentiae praemium fuisse nihil sane mihi legisse videor: tantummodo coniectura ducor ad suspicandum".
} 
provavelmente aconteceu a muitos outros, o teria sepultado no esquecimento". ${ }^{176}$ Assim, a escrita pode se constituir como um remédio contra o esquecimento (oblivio), e o Brutus "livra do esquecimento" mais de duzentos oradores romanos. ${ }^{177}$ Cicero aponta Catão como o primeiro (antiquior) a deixar escritos, pelo menos dos que são dignos de serem lembrados (cuius quidem scripta proferenda putem 61), fazendo questão de marcar o intervalo de tempo entre a morte de Catão (149 a. C.) e o ano de seu consulado (63 a. C.), de forma a estabelecer um vínculo entre esses dois períodos das letras latinas. A partir da geração de Catão, a oratória latina, por assim dizer, segue um curso de aperfeiçoamento e refinamento.

O costume de escrever discursos já é bastante difundido na geração posterior à de Catão. De fato, Caio Lélio, Públio Cipião e Sérvio Sulpício Galba escreveram. Quando Cícero se refere aos discursos de Lélio e Cipião, ele afirma que por meio deles é possível ter uma ideia do engenho dos oradores (82). Segundo ele, o primado da eloquência dessa geração estava nas mãos de Galba. Embora grande orador, Galba não era tão bom escritor. A personagem Bruto interroga Cícero sobre o motivo de os discursos de Galba não revelarem o vigor que Cícero lhe confere e acrescenta que esse tipo de contraste só pode ser feito com aqueles que deixaram algo escrito (91). Então, Cícero faz algumas considerações sobre o não escrever e o não escrever tão bem quanto se discursa.

São dois os propósitos de escrever discursos: como auxílio na preparação de um discurso e como meio de legar à posteridade um testemunho do próprio engenho. ${ }^{178}$ Cícero afirma que alguns não escrevem para não acrescentar um trabalho doméstico ao forense, pois muitos discursos são escritos depois de pronunciados (91). Outros não se esforçam para se tornarem melhores, pois para Cícero nada auxilia mais a oratória do que o exercício da escrita. Há também aqueles que não deixaram escritos, porque estavam persuadidos de

\footnotetext{
${ }^{176}$ Brutus 60: "id ipsum nisi unius testimonio cognitum, hunc vetustas, ut alios fortasse multos, oblivione obruisset".

${ }^{177}$ Segundo Sumner (1973, p. 3): "Cicero mentions well over two hundred orators in the course of the dialogue".

${ }^{178}$ Gowing (2000, p. 45): "writting here is seen to fulfill two possible purposes: it can 1) improve one's speech, i. e., working out on paper ahead of time what one intends to say will result in a better speech, and 2) create and preserve (or tarnish) a memory of one's skill."
} 
que alcançaram uma glória oratória suficiente e que ela seria ainda maior se seus escritos não fossem julgados pelos críticos. E há também aqueles que pensam ser mais capazes de discursar do que de escrever, o que acontece com aqueles muito engenhosos e não muito cultos, como é o caso de Galba (92).

\section{Eloquentia domestica}

No prólogo do Brutus, Cicero lamenta a ausência da voz de Hortênsio no fórum, que havia sido o teatro de seu engenho. No epílogo do diálogo, Cícero afirma que a voz de Hortênsio foi silenciada pela sua morte, mas que a dele, Cícero, foi silenciada pela morte do espaço público (sic Hortensi vox exstincta fato suo est, nostra publico 328). Já que não há mais a via da oratória judicial e política, expressa pela voz, resta a opção da oratória doméstica e privada, expressa pela escrita.

\section{Sobre a personificação da Eloquentia}

Ao final do diálogo, Cícero diz a Bruto que, depois da morte de Hortênsio, a eloquentia se tornou órfã, e eles se tornaram seus tutores (Brutus 330). Ela é representada como uma mulher adulta que deve ser confinada e preservada no espaço doméstico, protegida da avidez de pretendentes desonrados (impudentes procos). Lembremos que ela havia nascido para os tribunais e assembleias (a multitudine autem et a foro, cui nata eloquentia est 283) Com essa imagem, Cícero forja uma personificação da eloquentia. O seu confinamento ao espaço doméstico parece representar sua manutenção no âmbito da escrita, bem como no dos exercícios oratórios, as posteriores declamações. Despojado do espaço público de discussão, Cícero se utiliza do espaço privado para atuar publicamente. ${ }^{179}$

\footnotetext{
${ }^{179}$ NARDUCCI (1997, p. 117): "Ovviamente lo stesso ritiro dell'oratoria nella sfera privata si configura sia come un atto direttamente politico - equivalente al rifiuto di mettere la propria parola al servizio di Cesare -, sia come opera di riflessione etico-politica: le declamazioni che nello stesso anno del Brutus, il 46, Cicerone teneva in casa alla presenza di giovani dell'ambiente cesariano, affrontavano le tematiche inerenti alla sorte della res publica, sforzandosi di prefigurare l'avvenire della città e di fissare i criteri
} 
Segundo Stroup, no Brutus, a personificação da eloquentia é constituída de três momentos principais. No primeiro, trata-se da sua situação presente, ela está emudecida (eloquentia obmutuit 22). Em seguida, trata-se da eloquentia no passado, quando Cícero afirma que ela deixou o Pireu e percorreu as ilhas de toda a Ásia. No terceiro momento, referindo-se à eloquentia futura, Cícero forja a imagem de uma mulher adulta que deve ser confinada ao espaço doméstico. ${ }^{180}$ A imagem da eloquentia doméstica sugere a manutenção de sua voz através do discurso escrito. ${ }^{181}$

De fato, opera no Brutus a distinção entre o discurso oral (dicere) e o discurso escrito (scribere). Lembremos do comentário de Cícero sobre a oratória de Lélio e Galba. Segundo ele, alguns oradores não escrevem para não acrescentar um domesticus labor ao forensis labor (91). Forensis labor se refere a dicere, enquanto domesticus labor se refere a scribere. Lembremos também que a maioria dos discursos são escritos depois de pronunciados, não para serem pronunciados. No caso de Galba, seu discurso escrito não revela o vigor de seu discurso oral: são habilidades distintas. Enquanto o engenho de Galba lhe possibilita discursar bem, sua técnica não lhe permite escrever bem. Nesse sentido, Cícero distingue dois aspectos da eloquência: por um lado, sua finalidade persuasiva diante da multitudo; por outro lado, seu caráter literário destinado à apreciação de um público culto. ${ }^{182}$ Ao descrever a oratória de Isócrates, Cícero diz que ele carecia da luz do fórum (ou seja, dicere) e que sua glória foi alcançada entre as paredes de sua casa (intra parietes aluit eam gloriam 32). Cícero escreve que a casa de Isócrates era, por assim dizer, uma escola e uma oficina de oratória (cuius domus cunctae Graeciae quasi ludus quidam patuit atque officina dicendi 32). Incorporando, por assim dizer, os aspectos do que vimos chamando eloquentia domestica, Isócrates é representado como scriptor e como magister dicendi

della scelta tra diverse possibili alternative di comportamento."

${ }^{180}$ Cf. Stroup (2003, p. 128).

${ }^{181}$ Stroup (2003, p. 138): "In his final image of Eloquentia made 'domestic', the orator is suggestively interweaving the spheres of cultural and literary practice and relying upon his reading audience to recognize the implications."

${ }^{182}$ NARDUCCI (1997, p. 118): "Il contrasto tra i due criteri è in definitiva quello tra i due aspetti dell'eloquenza: strumento di immediata persuasione della multitudo, e forma di letteratura destinata alla fruizione di un pubblico colto; aspetti difficilmente conciliabili sul piano teorico, ma che Cicerone ha saputo quasi sempre ricomporre nella sua pratica di scrittore di orazioni, riuscendo a conservare nel testo, grazie alla sua arte sovrana, moltissime delle qualità, anche emozionali, del discorso pronunciato." 
(is et ipse scripta multa praeclare et docuit alios 32). ${ }^{183}$ Dicere e scribere são campos distintos da eloquentia. Podemos, assim, distinguir orator e scriptor. Se, por um lado, Isócrates optou por se tornar scriptor, Cícero, por outro lado, se tornou scriptor em razão das adversidades políticas.

Quando Cícero convoca Bruto a ajudá-lo a proteger a eloquentia no espaço privado da domus, ele se refere à manutenção e sobrevivência da eloquentia no âmbito do texto escrito, em obras de filosofia, história, retórica entre outros gêneros, sendo o Brutus um exemplo disso. ${ }^{184}$ Outro bom exemplo disso é o que Cícero afirma no prólogo do primeiro livro das Tusculanae. Comparando-se a Aristóteles, que acrescentou o estudo da retórica ao da filosofia, Cícero, sem abandonar o antigo estudo oratório, vai se dedicar à filosofia e afirma que sua obra filosófica é sua declamação da velhice. ${ }^{185}$ Não só o Brutus e as Tusculanae, mas todas as demais obras de retórica e filosofia, podem ser vistos como espécies do domesticus labor de Cícero.

\footnotetext{
${ }^{183} \mathrm{Em}$ outra passagem do Brutus, comentando a oratória de Caio Pisão, Cícero novamente distingue o forensis labor do domesticus labor, que é caracterizado, seja como escrita preparatória, seja como exercício declamatório. Brutus 272: "Ele [Pisão] nunca tinha tempo livre, ora discursando no fórum, ora preparando-se em casa, ora escrevendo, ora planejando discursos." nullum tempus illi umquam uacabat aut a forensi dictione aut a commentatione domestica aut a scribendo aut a cogitando.

${ }^{184}$ Stroup (2003, p. 128): "By the end of Brutus [...] Cicero has transformed the abstract concept of Republican Eloquentia from a poorly defined catchword for rhetorical ability into a vibrantly personified promise of social and literary resurrection for the producers of written Eloquentia - in the form of rhetorical, historiographical, and philosophical treatises - themselves."

${ }^{185}$ Tusculanae I, 7: Sed ut Aristoteles, vir summo ingenio, scientia, copia, cum motus esset Isocratis rhetoris gloria, dicere docere etiam coepit adulescentes et prudentiam cum eloquentia iungere, sic nobis placet nec pristinum dicendi studium deponere et in hac maiore et uberiore arte versari [...] ut enim antea declamitabam causas, quod nemo me diutius fecit, sic haec mihi nunc senilis est declamatio.
} 


\title{
Tradução
}

\author{
Brutus $^{186}$
}

\section{Bruto}

[1] I. (1) Cum e Cilicia decedens Rhodum uenissem et eo mihi de Q. Hortensi morte esset adlatum, opinione omnium maiorem animo cepi dolorem. nam et amico amisso cum consuetudine iucunda tum multorum officiorum coniunctione me priuatum uidebam et interitu talis auguris dignitatem nostri conlegi deminutam dolebam; qua in cogitatione et cooptatum me ab eo in conlegium recordabar, in quo iuratus iudicium dignitatis meae fecerat, et inauguratum ab eodem; ex quo augurum institutis in parentis eum loco colere debebam. (2) Augebat etiam molestiam, quod magna sapientium ciuium bonorumque penuria uir egregius coniunctissimusque mecum consiliorum omnium societate alienissimo rei publicae tempore exstinctus et auctoritatis et prudentiae suae
[1] Quando, de retorno da província ${ }^{1}$ da Cilícia, eu cheguei a Rodes e lá fui informado da morte de Quinto Hortênsio, senti uma dor maior do que todos poderiam imaginar. De fato, por um lado, com a perda um amigo via-me privado tanto de uma prazerosa relação familiar como de uma colaboração em muitos negócios, por outro lado, com a morte de um áugure de tal valor lamentava a diminuição do prestígio de nosso colégio. Pensando nisso, recordava que eu não só havia sido admitido por ele no colégio, em cujo juramento ele dera testemunho do meu prestígio, como havia sido consagrado áugure também por ele; o que me obrigava, segundo a tradição dos áugures, a venerá-lo como um pai. [2] Além disso, aumentava meu sofrimento o fato de que em meio à grande escassez de cidadãos sábios e bons, um homem distinto e muito unido a mim pela aliança em todos os desígnios morrera em um momento

\footnotetext{
${ }^{186}$ Utilizamos como base da tradução a edição crítica estabelecida por Enrica Malcovati para a coleção Teubner em 1965.
} 
triste nobis desiderium reliquerat; dolebamque quod non, ut plerique putabant, aduersarium aut obtrectatorem laudum mearum sed socium potius et consortem gloriosi laboris amiseram. (3) Etenim si in leuiorum artium studio memoriae proditum est poetas nobilis poetarum aequalium morte doluisse, quo tandem animo eius interitum ferre debui, cum quo certare erat gloriosius quam omnino aduersarium non habere? cum praesertim non modo numquam sit aut illius a me cursus impeditus aut ab illo meus, sed contra semper alter ab altero adiutus et communicando et monendo et fauendo. (4) Sed quoniam perpetua quadam felicitate usus ille cessit e uita suo magis quam suorum ciuium tempore et tum occidit, cum lugere facilius rem publicam posset, si uiueret, quam iuuare, uixitque tam diu quam licuit in ciuitate bene beateque uiuere, nostro incommodo detrimentoque, si est ita necesse, doleamus, illius uero mortis opportunitatem beneuolentia potius quam misericordia prosequamur, ut, quotienscumque de clarissumo et beatissumo uiro cogitemus, illum potius quam nosmet ipsos diligere uideamur. (5) Nam si id dolemus, quod eo iam frui nobis non licet, nostrum est id malum; quod modice feramus, ne id non ad amicitiam sed ad domesticam utilitatem referre uideamur: sin tamquam illi muito difícil para a república, deixandonos a triste saudade de sua autoridade e de sua sabedoria; e eu lamentava porque havia perdido não um adversário, como pensava a maioria, ou um detrator de minha reputação, mas antes um aliado e companheiro de gloriosa labuta. [3] Ora, se na prática das artes menores a tradição diz que poetas célebres lamentavam a morte dos poetas contemporâneos, o que deveria eu ter sentido com a morte daquele com quem era mais glorioso rivalizar do que simplesmente não ter um adversário? Sobretudo porque não só a carreira dele nunca foi obstruída por mim nem a minha por ele, mas, pelo contrário, sempre um foi ajudado pelo outro, ora compartilhando, ora aconselhando, ora apoiando. [4] Porém, uma vez que ele desfrutou de uma prosperidade contínua, deixou a vida em um momento mais oportuno para ele do que para seus concidadãos e morreu num momento em que se poderia mais facilmente lastimar a situação da república, se estivesse vivo, do que ajudá-la, e viveu durante todo tempo em que era possível viver bem e feliz nesta cidade, diante do inevitável lamentemos nosso infortúnio e nossa perda, mas recebamos a ocasião de sua morte antes com benevolência do que com enternecimento, de modo que todas as vezes que pensarmos nesse homem tão ilustre e afortunado pareçamos amar mais a ele do que a nós mesmos. [5] De fato, se sofremos porque não nos é mais possível aproveitar de sua companhia, esse mal é nosso e devemos suportá-lo com mo- 
ipsi acerbitatis aliquid acciderit angimur, summam eius felicitatem non satis grato animo interpretamur.

\section{[2] II. (6) Etenim si uiueret Q-} Hortensius, cetera fortasse desideraret una cum reliquis bonis et fortibus ciuibus, hunc autem aut praeter ceteros aut cum paucis sustineret dolorem, cum forum populi Romani, quod fuisset quasi theatrum illius ingeni, uoce erudita et Romanis Graecisque auribus digna spoliatum atque orbatum uideret. (7) Equidem angor animo non consili, non ingeni, non auctoritatis armis egere rem publicam, quae didiceram tractare quibusque me adsuefeceram quaeque erant propria cum praestantis in re publica uiri tum bene moratae et bene constitutae ciuitatis. quod si fuit in re publica tempus ullum, cum extorquere arma posset e manibus iratorum ciuium boni ciuis auctoritas et oratio, tum profecto fuit, cum patrocinium pacis exclusum est aut errore hominum aut timore. (8) Ita nobismet ipsis accidit ut, quamquam essent multo magis alia lugenda, tamen hoc doleremus quod, quo tempore aetas nostra perfuncta rebus amplissimis tamquam in portum confugere deberet non inertiae neque desidiae, sed oti moderati atque honesti, cumque ipsa deração, para que não pareça que não o atribuimos à nossa amizade mas à nossa própria utilidade, e se nos angustiamos como se lhe tivesse acontecido alguma desgraça, não interpretamos com suficiente gratidão a sua extrema felicidade. ${ }^{2}$

[6] Com efeito, se Quinto Hortênsio estivesse vivo, talvez sentisse a falta de outras coisas junto com os demais cidadãos bons e de valor, mas provaria essa dor mais do que ninguém ou com alguns poucos no momento em que visse o fórum do povo romano, que fora como que o teatro do seu engenho, despojado e órfão de sua voz erudita, digna de ouvidos gregos e romanos. [7] De minha parte, angustia-me que a república não sinta falta das armas do discernimento, da inteligência, da autoridade, que eu aprendera a manejar e com as quais me habituara, e que eram próprias tanto de um homem de proeminência na república, como de uma cidade de bons costumes e bem constituída. Mas se houve na república algum momento em que a autoridade e a palavra do bom cidadão eram capazes de arrancar as armas das mãos de cidadãos enfurecidos, certamente foi aquele em que a defesa da paz foi excluída fosse por imprudência dos homens fosse por medo. [8] Assim no nosso caso aconteceu que, embora houvesse muito mais a lamentar, sofremos com o fato de que no exato momento de nossa vida em que, depois de cumprir as funções públicas mais distintas, deveríamos, por assim dizer, refugiarmo-nos num porto não de inércia nem de indolência, mas sim de uma tranquilidade moderada 
oratio iam nostra canesceret haberetque suam quandam maturitatem et quasi senectutem, tum arma sunt ea sumpta, quibus illi ipsi, qui didicerant eis uti gloriose, quem ad modum salutariter uterentur non reperiebant. (9) Itaque ei mihi uidentur fortunate beateque uixisse cum in ceteris ciuitatibus tum maxume in nostra, quibus cum auctoritate rerumque gestarum gloria tum etiam sapientiae laude perfrui licuit. quorum memoria et recordatio in maxumis nostris grauissimisque curis iucunda sane fuit, cum in eam nuper ex sermone quodam incidissemus. [3] III. (10) Nam cum inambularem in xysto et essem otiosus domi, M. ad me Brutus, ut consueuerat, cum T. Pomponio uenerat, homines cum inter se coniuncti tum mihi ita cari itaque iucundi, ut eorum aspectu omnis quae me angebat de re publica cura consederit. quos postquam salutaui: Quid uos, inquam, Brute et Attice? numquid tandem noui? Nihil sane, inquit Brutus, quod quidem aut tu audire uelis aut ego pro certo dicere audeam.

(11) Tum Atticus: eo, inquit, ad te animo uenimus, ut de re publica esset silentium et aliquid audiremus potius ex te, quam te adficeremus ulla molestia. Vos uero, inquam, Attice, et praesentem me cura leuatis et e honesta, quando minha eloquência começava a encanecer e alcançava sua maturidade e uma certa velhice, foi então que pegaram em armas aqueles mesmos que haviam aprendido a fazer uso delas de modo glorioso, mas que não encontravam um modo saudável de utilizá-las. [9] Assim, parece que viveram bem afortunados e felizes não apenas nas demais cidades, mas sobretudo na nossa, aqueles que puderam desfrutar não só de sua autoridade e da glória de seus feitos mas também do prestígio de sua sabedoria. A memória e a recordação deles, em meio às nossas tão grandes e graves preocupações, nos foram muito agradáveis quando há algum tempo elas nos ocorreram numa conversa. [10] Com efeito, quando eu estava caminhando no pórtico e encontrava-me ocioso em casa, veio até mim Marco Bruto, como era seu costume, junto com Tito Pompônio, pessoas não só próximas entre si mas também tão caras e tão agradáveis a mim que ao vê-los toda preocupação que me angustiava quanto à república cessava. Depois de tê-los saudado: - O que traz vocês aqui, Ático e Bruto?, perguntei, Alguma novidade afinal? ${ }^{3}$ - Não, respondeu Bruto, não há absolutamente nada, pelo menos, do que queiras ouvir ou do que eu ouse dizer com certeza.

[11] Ático, então, disse: — Viemos fazer-te uma visita dispostos a manter o silêncio sobre política e ouvir alguma coisa de ti em vez de causar-te alguma aflição. - Ora, Ático, vocês, continuei, tanto me aliviam a preocupação estando presentes, 
absenti magna solacia dedistis. nam uestris primum litteris recreatus me ad pristina studia reuocaui. Tum ille: legi, inquit, perlubenter epistulam, quam ad te Brutus misit ex Asia, qua mihi uisus est et monere te prudenter et consolari amicissume. (12) Recte, inquam, est uisus: nam me istis scito litteris ex diuturna perturbatione totius ualetudinis tamquam ad aspiciendam lucem esse reuocatum. atque ut post Cannensem illam calamitatem primum Marcelli ad Nolam proelio populus se Romanus erexit posteaque prosperae res deinceps multae consecutae sunt, sic post rerum nostrarum et communium grauissumos casus nihil ante epistulam Bruti mihi accidit, quod uellem aut quod aliqua ex parte sollicitudines adleuaret meas.

(13) Tum Brutus: uolui id quidem efficere certe et capio magnum fructum, si quidem quod uolui tanta in re consecutus sum. sed scire cupio, quae te Attici litterae delectauerint. Istae uero, inquam, Brute, non modo delectationem mihi, sed etiam, ut spero, salutem adtulerunt. Salutem? inquit ille. quodnam tandem genus istuc tam praeclarum litterarum fuit? An mihi potuit, inquam, esse aut gratior ulla salutatio aut ad hoc tempus aptior quam illius libri, como também me proporcionaram grande consolação estando ausentes. De fato, primeiramente reanimado pelos seus escritos retornei aos meus antigos estudos. Ele, então, disse: - Li com muito entusiasmo a epístola que Bruto lhe enviou da Ásia, em que me pareceu não apenas aconselhálo com prudência mas também consolá-lo muito afetuosamente. [12] — Tens razão, retruquei, pois saiba que essa carta, após um longo período de perturbação da minha saúde em geral, me fez, em certo sentido, voltar a ver a luz do dia. E assim como depois daquele famoso desastre em Canas, num primeiro momento, o povo romano recobrou suas forças com Marcelo na batalha de Nola ${ }^{4}$ e depois, num segundo momento, com numerosas e sucessivas conquistas que se seguiram, assim também depois dos gravíssimos incidentes que ocorreram a mim e a meus concidadãos não houve antes da epístola de Bruto nada que eu desejasse ou que aliviasse mesmo parte de minhas preocupações.

[13] Bruto, então, disse: - Era exatamente isso que eu esperava e colho grandes frutos, se é verdade que atingi meu propósito em assunto de tamanha importância. Mas desejo saber qual escrito de Ático tanto o agradou. - Na verdade, Bruto, respondi, este escrito proporcionoume não apenas prazer mas também, tenho esperança, minha salvação. - Salvação, ele perguntou, mas que gênero de escrito tão magnífico era esse? - Acaso, continuei, poderia haver para mim uma saudação mais bem vinda ou mais oportuna 
quo me hic adfatus quasi iacentem excitauit? (14) Tum ille: nempe eum dicis, inquit, quo iste omnem rerum memoriam breuiter et, ut mihi quidem uisum est, perdiligenter complexus est? Istum ipsum, inquam, Brute, dico librum mihi saluti fuisse. [4] IV. Tum Atticus: optatissimum mihi quidem est quod dicis; sed quid tandem habuit liber iste, quod tibi aut noum aut tanto usui posset esse?

(15) Ille uero et noua, inquam, mihi quidem multa et eam utilitatem quam requirebam, ut explicatis ordinibus temporum uno in conspectu omnia uiderem. quae cum studiose tractare coepissem, ipsa mihi tractatio litterarum salutaris fuit admonuitque, Pomponi, ut a te ipso sumerem aliquid ad me reficiendum teque remunerandum si non pari, at grato tamen munere: quamquam illud Hesiodium laudatur a doctis, quod eadem mensura reddere iubet qua acceperis aut etiam cumulatiore, si possis. (16) Ego autem uoluntatem tibi profecto emetiar, sed rem ipsam nondum posse uideor; idque ut ignoscas, a te peto. nec enim ex nouis, ut agricolae solent, fructibus est unde tibi reddam quod accepi sic omnis fetus repressus exustusque flos siti ueteris ubertatis exaruit nec ex conditis, qui iacent in tenebris et ad quos omnis nobis aditus, para esta circunstância do que o seu livro, em que ele, dirigindo-se a mim, como que despertou-me de meu abatimento? [14] Bruto, então, disse: - Você está certamente se referindo àquele livro em que ele abarcou toda a história de modo breve e, pelo menos segundo me parece, com muita diligência? - É esse livro mesmo, Bruto, respondi, que eu afirmo ter sido minha salvação. Ático, então, disse: —É um enorme prazer para mim o que você diz, mas o que há nesse livro que lhe possa ser novo ou tão útil?

[15] Então, respondi: - Ora, esse livro não só me apresentou muita coisa nova como também me foi útil em algo que eu procurava, a saber, que eu conseguisse perceber com uma só visada, desenvolvido numa ordem cronológica, todo o curso dos acontecimentos. Quando eu comecei a manuseá-lo atentamente, o próprio ato de manusear um livro foi saudável para mim e me estimulou, Pompônio, a assumir o dever de restituir-lhe de algum modo e recompensar-lhe, se não com um presente de igual valor, mas que ao menos revelasse minha gratidão, muito embora seja citada entre os eruditos a afirmação de Hesíodo que recomenda que se devolva na mesma medida o que se recebeu, ou, se possível, com algum acréscimo. [16] De minha parte, certamente retribuirei na justa medida a sua benevolência, mas quanto ao débito em si, creio que ainda não sou capaz, e por isso peço o seu perdão. É que não tenho como retribuir-lhe o que recebi com os frutos de uma nova colheita, como cos- 
qui paene solis patuit, obstructus est. seremus igitur aliquid tamquam in inculto et derelicto solo; quod ita diligenter colemus, ut impendiis etiam augere possimus largitatem tui muneris: modo idem noster animus efficere possit quod ager, qui quom multos annos quieuit, uberiores efferre fruges solet.

(17) Tum ille: ego uero et exspectabo ea quae polliceris, nec exigam nisi tuo commodo et erunt mihi pergrata, si solueris. Mihi quoque, inquit Brutus, (et) exspectanda sunt ea quae Attico polliceris, etsi fortasse ego a te huius uoluntarius procurator petam, quod ipse, cui debes, incommodo exacturum negat. [5] V. (18) At uero, inquam, tibi ego, Brute, non soluam, nisi prius a te cauero amplius eo nomine neminem, cuius petitio sit, petiturum. Non mehercule, inquit, tibi repromittere istuc quidem ausim. nam hunc, qui negat, uideo flagitatorem non illum quidem tibi molestum, sed adsiduum tamen et acrem fore. Tum Pomponius: ego uero, inquit, Brutum nihil mentiri puto. uideor enim iam te ausurus esse appellare, quoniam longo interuallo modo primum animadu- tumam fazer os agricultores - todo fruto foi sufocado e a flor queimada pela seca perdeu o antigo viço - , nem com a safra estocada em armazém, que jaz na escuridão e à qual todo acesso, que quase apenas a mim esteve aberto, agora está obstruído. Portanto, plantaremos uma semente em solo, por assim dizer, inculto e abandonado, e o cultivaremos com tanto cuidado que com os juros poderemos até aumentar a magnificência de seu presente, desde que que meu ânimo possa fazer tal como o campo que depois de muitos anos de repouso costuma produzir frutos em maior abundância.

[17] Ele, então, observou: - Eu, certamente, aguardarei o que promete e não cobrarei de você se não for de sua conveniência, mas serei muito grato pelo pagamento dessa dívida. - Eu também, acrescentou Bruto, vou aguardar o que você promete a Ático, se bem que talvez eu, como seu mandatário voluntário, possa reclamar em juízo aquilo que ele, a quem você deve, diz que não irá lhe cobrar se não for conveniente para você. [18] - Mas eu, Bruto, repliquei, não lhe pagarei sem que antes eu tenha sua garatia de que ninguém voltará a reclamar em nome de quem tem o direito de reclamação. - Decididamente, respondeu Bruto, eu não me atreveria a fazer esta promessa. Pois, embora veja que esse credor, que afirma o contrário, não lhe será desagradável, no entanto, será insistente e impetuoso. Então, Pompônio disse: - Eu, realmente, penso que Bruto não falou nenhuma mentira. Pois creio 
erti paulo te hilariorem. (19) Itaque quoniam hic quod mihi deberetur se exacturum professus est, quod huic debes, ego a te peto. Quidnam id? inquam. Ut scribas, inquit, aliquid; iam pridem enim conticuerunt tuae litterae. nam ut illos de re publica libros edidisti, nihil a te sane postea accepimus: eisque nosmet ipsi ad rerum nostrarum memoriam comprehendendam impulsi atque incensi sumus. sed illa, cum poteris; atque ut possis, rogo. (20) Nunc uero, inquit, si es animo uacuo, expone nobis quod quaerimus. Quidnam est id? inquam. Quod mihi nuper in Tusculano inchoauisti de oratoribus: quando esse coepissent, qui etiam et quales fuissent. quem ego sermonem cum ad Brutum tuum uel nostrum potius detulissem, magnopere hic audire se uelle dixit. itaque hunc elegimus diem, cum te sciremus esse uacuum. quare, si tibi est commodum, ede illa quae coeperas et Bruto et mihi.

(21) Ego uero, inquam, si potuero, faciam uobis satis. Poteris, inquit: relaxa modo paulum animum aut sane, si potes, libera. Nempe igitur hinc tum, Pomponi, ductus est sermo, quod erat a me mentio facta causam Deiotari fidelissimi atque optumi regis ornatissume et copiosis- que nesse caso eu me atreverei a lhe convocar em juízo, já que agora pela primeira vez depois de um longo intervalo vejo você mais bem humorado. [19] Assim, já que ele me prometeu cobrar o que me é devido, eu reclamo a você o que deve a ele. - Do que se trata? Perguntei. - Que você escreva algo, respondeu. Já há muito os seus escritos silenciaram. De fato, desde que você publicou os livros sobre a república, não recebemos de você absolutamente mais nada. E por eles eu me senti impelido e inflamado a abarcar a nossa história. Mas isso, quando você puder, e rogo-lhe que possa. [20] Agora, então, continuou, se você estiver desocupado, exponha aquilo que pedimos. - Ora, do que se trata? Perguntei. - Daquela conversa que há pouco tempo você iniciou comigo na vila de Túsculo sobre os oradores: quando surgiram, quem eram e também quais eram as suas qualidades. Quando eu fiz referência a essa conversa ao seu amigo, ou antes, ao nosso amigo Bruto, ele disse que queria muito ouvir. Assim, escolhemos esse dia em que sabíamos que você estaria desocupado. Portanto, se lhe for conveniente, conte para mim e para Bruto o que você tinha começado.

[21] — Quanto a mim, respondi, se eu puder, satisfarei a vocês. - Você vai conseguir sim, disse ele. Alivie um pouco a mente ou, se possível, liberte-se de todo de seus pensamentos. - Pois bem, Pompônio, tal conversa se originou porque eu fizera menção à causa de Dejótaro, aliado muito fiel e excelente rei, que eu ouvira defendida 
sume a Bruto me audisse defensam. [6] VI. Scio, inquit, ab isto initio tractum esse sermonem teque Bruti dolentem uicem quasi defleuisse iudiciorum uastitatem et fori. (22) Feci, inquam, istuc quidem et saepe facio. nam mihi, Brute, in te intuenti crebro in mentem uenit uereri, ecquodnam curriculum aliquando sit habitura tua et natura admirabilis et exquisita doctrina et singularis industria. cum enim in maxumis causis uersatus esses et cum tibi aetas nostra iam cederet fascisque submitteret, subito in ciuitate cum alia ceciderunt tum etiam ea ipsa, de qua disputare ordimur, eloquentia obmutuit. (23) Tum ille: ceterarum rerum causa, inquit, istuc et doleo et dolendum puto; dicendi autem me non tam fructus et gloria quam studium ipsum exercitatioque delectat: quod mihi nulla res eripiet te praesertim tam studiosum et - dicere enim bene nemo potest nisi qui prudenter intellegit; quare qui eloquentiae uerae dat operam, dat prudentiae, qua ne maxumis quidem in bellis aequo animo carere quisquam potest.

(24) Praeclare, inquam, Brute, dicis eoque magis ista dicendi laude delector, quod cetera, quae sunt quondam habita in ciuitate pulcherrima, nemo est tam humilis qui se non aut posse adipisci aut adeptum putet; por Bruto de modo extremamente ornado e copioso. - Bem sei, disse ele, que tomando esse início a conversa se estendeu e você lamentava o destino pessoal de Bruto e por assim dizer deplorava a devastação dos tribunais e do fórum. [22] - Fiz isso sim, continuei, e muita vez o faço. Pois, quando eu olho para você, Bruto, sempre me vem em mente o temor sobre qual caminho seguirá a sua natureza admirável, o seu refinado estudo, a sua singular diligência. De fato, quando você já havia atuado em causas importantíssimas e quando minha geração já começava a lhe dar lugar e inclinar os feixes diante de você, subitamente em nossa cidade enquanto muitas instituições sucumbiram, também a própria eloquência, sobre a qual começamos a discutir, emudeceu. [23] Então, ele disse: - Por outras razões, eu lamento e penso que é algo que se deve lamentar, mas a recompensa e a glória oratórias não me agradam tanto quanto o estudo em si e o treinamento constante, o que nada poderá tirar de mim, ainda mais que você é tão dedicado e ${ }^{* * *}$. De fato, ninguém pode discursar bem a não ser quem pensa com sabedoria. Portanto, quem se dedica à verdadeira eloquência, se dedica à sabedoria, da qual mesmo nas mais graves guerras ninguém pode prescindir com tranquilidade.

[24] - É magnífico, Bruto, o que você diz, retruquei, e me agrada esse elogio da oratória porque entre diversas coisas outrora tidas como muito honradas em nossa cidade não há ninguém tão abjeto que não se considere capaz de alcançá-las ou que 
eloquentem neminem uideo factum esse uictoria. sed quo facilius sermo explicetur, sedentes, si uidetur, agamus. Cum idem placuisset illis, tum in pratulo propter Platonis statuam consedimus. (25) Hic ego: laudare igitur eloquentiam et quanta uis sit eius expromere quantamque eis, qui sint eam consecuti, dignitatem afferat, neque propositum nobis est hoc loco neque necessarium. hoc uero sine ulla dubitatione confirmauerim, siue illa arte pariatur aliqua siue exercitatione quadam siue natura, rem unam esse omnium difficillumam. quibus enim ex quinque rebus constare dicitur, earum una quaeque est ars ipsa magna per sese. quare quinque artium concursus maxumarum quantam uim quantamque difficultatem habeat existimari potest.

[7] VII. (26) Testis est Graecia, quae cum eloquentiae studio sit incensa iamdiuque excellat in ea praestetque ceteris, tamen omnis artes uetustiores habet et multo ante non inuentas solum, sed etiam perfectas, quam haec est a Graecis elaborata dicendi uis atque copia. in quam cum intueor, maxime mihi occurrunt, Attice, et quasi lucent Athenae tuae, qua in urbe primum se orator extulit primumque etiam monumentis et litteris oratio est coepta mandari. (27) Tamen ante Periclem, pense já tê-las alcançado, mas tornar-se eloquente eu não vejo ninguém que o tenha conseguido pela vitória. Mas para que a conversa siga com mais comodidade, se lhes parece bem, conversemos sentados. Como a proposta os agradou, então sentamos no pequeno prado junto à estátua de Platão. [25] Comecei, então: - Pois bem, fazer o elogio da eloquência e revelar quão grande é seu poder e quanto prestígio ela confere àqueles que a alcançaram não é nosso propósito aqui nem é algo necessário. ${ }^{5}$ Mas isto eu poderia assegurar sem nenhuma hesitação: quer ela seja produzida por alguma arte, quer pelo treinamento constante, quer pela disposição natural, não há nada no mundo mais difícil. De fato, afirma-se que ela é composta de cinco partes, das quais cada uma é uma arte notável por si mesma. Por isso, pode-se estimar quanta força e quanta dificuldade apresenta o concurso dessas cinco grandes artes.

[26] Testemunha disso é a Grécia, que embora tenha se inflamado de entusiasmo pela eloquência e há muito atingido nela a excelência e a superioridade diante dos demais povos, conhecia todas as artes mais antigas e não só as descobriu como também as aprimorou muito antes que fosse desenvolvida pelos gregos esta capacidade e a riqueza oratória. Quando eu penso nela, Ático, me vem particularmente a sua Atenas, como a brilhar, cidade onde pela primeira vez surgiu um orador e também pela primeira vez a oratória passou a ser confiada aos registros históricos e aos es- 
cuius scripta quaedam feruntur, et Thucydidem, qui non nascentibus Athenis sed iam adultis fuerunt, littera nulla est, quae quidem ornatum aliquem habeat et oratoris esse uideatur. quamquam opinio est et eum, qui multis annis ante hos fuerit, Pisistratum et paulo seniorem etiam Solonem posteaque Clisthenem multum, ut temporibus illis, ualuisse dicendo. (28) Post hanc aetatem aliquot annis, ut ex Attici monumentis potest perspici, Themistocles fuit, quem constat cum prudentia tum etiam eloquentia praestitisse; post Pericles, qui cum floreret omni genere uirtutis, hac tamen fuit laude clarissumus. Cleonem etiam temporibus illis turbulentum illum quidem ciuem, sed tamen eloquentem constat fuisse. (29) Huic aetati suppares Alcibiades Critias Theramenes; quibus temporibus quod dicendi genus uiguerit ex Thucydidi scriptis, qui ipse tum fuit, intellegi maxume potest. grandes erant uerbis, crebri sententiis, compressione rerum breues et ob eam ipsam causam interdum subobscuri.

[8] VIII. (30) Sed ut intellectum est quantam uim haberet accurata et facta quodam modo oratio, tum etiam magistri dicendi multi subito exstiterunt. tum Leontinus Gorgias, Thrasymachus Calchedonius, Pro- critos. [27] Contudo, antes de Péricles, a quem são atribuídos alguns textos, e de Tucídides, que viveram não quando Atenas estava nascendo mas quando ela já era adulta, não houve nenhum escrito pelo menos que revelasse a beleza oratória e que parecesse próprio de um orador. Todavia, acredita-se que não só Pisístrato, que viveu muitos anos antes deles, mas também Sólon, um pouco mais velho que este, e posteriormente Clístenes foram, ao menos em suas épocas, muito habilidosos na oratória. [28] Alguns anos depois dessa geração, conforme se pode depreender dos registros de Ático, viveu Temístocles, que, como se sabe, era superior tanto pela prudência como também pela eloquência. Em seguida veio Péricles, que embora se distinguisse em toda espécie de virtude, foi o mais ilustre pela glória oratória. Também Cleão, naquele tempo, como se sabe, embora fosse um cidadão subversivo, era um homem eloquente. [29] Quase contemporâneos a ele foram Alcibíades, Crítias, Terâmenes, o gênero oratório em voga no período se pode conhecer sobretudo a partir dos escritos de Tucídides, também ele da mesma época. Eles eram elevados nas palavras, ricos nos pensamentos, breves ao condensar os argumentos e por isso mesmo às vezes um pouco obscuros.

[30] Mas quando se compreendeu quanta eficácia produzia um discurso bem preparado e bem elaborado segundo um certo método, foi então que também surgiram subitamente muitos mestres de oratória. Naquele tempo, Górgias de Leontinos, 
tagoras Abderites, Prodicus Ceius, Hippias Eleius in honore magno fuit; aliique multi temporibus eisdem docere se profitebantur adrogantibus sane uerbis, quemadmodum causa inferior - ita enim loquebantur dicendo fieri superior posset. (31) His opposuit sese Socrates, qui subtilitate quadam disputandi refellere eorum instituta solebat uerbis. huius ex uberrumis sermonibus exstiterunt doctissumi uiri; primumque tum philosophia non illa de natura, quae fuerat antiquior, sed haec, in qua de bonis rebus et malis deque hominum uita et moribus disputatur, inuenta dicitur. quod quoniam genus ab hoc quod proposuimus abhorret, philosophos aliud in tempus reiciamus; ad oratores, a quibus digressi sumus, reuertamur. (32) Exstitit igitur iam senibus illis quos paulo ante diximus Isocrates, cuius domus cunctae Graeciae quasi ludus quidam patuit atque officina dicendi; magnus orator et perfectus magister, quamquam forensi luce caruit intraque parietes aluit eam gloriam, quam nemo meo quidem iudicio est postea consecutus. is et ipse scripsit multa praeclare et docuit alios; et cum cetera melius quam superiores, tum primus intellexit etiam in soluta oratione, dum uersum effugeres, modum tamen et numerum quendam oportere seruari. (33) Ante hunc enim uerborum quasi structura et quaedam ad
Trasímaco da Calcedônia, Protágoras de Abdera, Pródico de Cio, Hípias de Élis eram tidos em alta conta, e muitos outros na mesma época professavam, em termos bem arrogantes, ensinar como se podia transformar pelo discurso a causa inferior, pois era assim que falavam, em causa superior. [31] A eles se opôs Sócrates, que com uma refinada argumentação costumava refutar suas doutrinas com palavras***. De suas conversas extremamente fecundas surgiram homens muito sábios, e se diz que pela primeira vez se descobriu a filosofia, não aquela da natureza, que era ainda mais antiga, mas sim a filosofia na qual os valores de bem e mal, a vida e o caráter dos homens são discutidos. Mas, uma vez que o gênero filosófico se afasta daquilo que nos propomos tratar, deixemos os filósofos para uma outra ocasião, voltemos aos oradores, dos quais nos afastamos. [32] Surgiu, então, quando já eram velhos aqueles de que falamos há pouco, Isócrates, cuja casa se tornou como que uma verdadeira escola e uma oficina de eloquência de toda Grécia, grande orador e perfeito mestre, embora lhe faltasse a luz do fórum e fizesse crescer entre as paredes de sua casa a glória que, pelo menos a meu ver, ninguém depois dele conseguiu. Ele não só escreveu muitas coisas excelentes como ensinou a outros tantos, e, de um lado, era superior a seus antecessores nos demais aspectos, de outro, foi o primeiro a perceber que mesmo na prosa, contanto que se evite o verso, é necessário estar atento ao ritmo e a certa cadência. [33] 
numerum conclusio nulla erat; aut, si quando erat, non apparebat eam dedita opera esse quaesitam - quae forsitan laus sit — ; uerum tamen natura magis tum casuque nonnunquam, quam aut ratione aliqua aut ulla obseruatione fiebat. (34) Ipsa enim natura circumscriptione quadam uerborum comprehendit concluditque sententiam, quae cum aptis constricta uerbis est, cadit etiam plerumque numerose. nam et aures ipsae quid plenum, quid inane sit iudicant et spiritu quasi necessitate aliqua uerborum comprensio terminatur; in quo non modo defici, sed etiam laborare turpe est.

[9] IX. (35) Tum fuit Lysias ipse quidem in causis forensibus non uersatus, sed egregie subtilis scriptor atque elegans, quem iam prope audeas oratorem perfectum dicere. nam plane quidem perfectum et quoi nihil admodum desit Demosthenem facile dixeris. nihil acute inueniri potuit in eis causis quas scripsit, nihil, ut ita dicam, subdole, nihil uersute, quod ille non uiderit; nihil subtiliter dici, nihil presse, nihil enucleate, quo fieri possit aliquid limatius; nihil contra grande, nihil incitatum, nihil ornatum uel uerborum grauitate uel sententiarum, quo quicquam esset elatius. (36) Huic Hyperides proxu-
Pois antes dele não havia nenhuma concatenação de palavras, por assim dizer, e nenhum arranjo cadenciado do período, ou, quando havia, não era evidente que havia sido buscado deliberadamente. O que talvez seja louvável, no entanto, isso ocorria mais por uma habilidade natural e às vezes por acaso do que por algum método ou uma regra qualquer. [34] Pois a própria natureza por uma espécie de circunlóquio abarca e encerra o pensamento, e quando ele é encadeado com palavras apropriadas muitas vezes se encerra também numa cadência rítmica. De fato, por um lado, os próprios ouvidos julgam o que é pleno, o que é vazio, por outro lado, o período está limitado, por assim dizer, a uma necessidade da respiração, nesse sentido é deplorável não apenas esbaforir-se mas também arquejar.

[35] Na mesma época, viveu Lísias, se ele mesmo não foi experimentado nas causas forenses, porém foi um escritor de notável refinamento e elegância, a ponto de já ser possível ousar designá-lo orador perfeito. A bem dizer, verdadeiramente perfeito e a quem não falta absolutamente nada poderia se designar sem hesitação Demóstenes. Nos discursos que escreveu, não havia nada de penetrante que pudesse ser encontrado, nada, por assim dizer, de artifício, nada de astúcia que ele não tivesse considerado; não havia nada que pudesse ser dito de modo tão minucioso, nada tão enxuto, nada tão sóbrio que pudesse haver algo mais refinado. Em contrapartida, não havia nada de elevado, nada de impetuoso, 
mus et Aeschines fuit et Lycurgus et Dinarchus et is, cuius nulla exstant scripta, Demades aliique plures. haec enim aetas effudit hanc copiam; et, ut opinio mea fert, sucus ille et sanguis incorruptus usque ad hanc aetatem oratorum fuit, in qua naturalis inesset, non fucatus nitor. (37) Phalereus enim successit eis senibus adulescens eruditissimus ille quidem horum omnium, sed non tam armis institutus quam palaestra. itaque delectabat magis Atheniensis quam inflammabat. processerat enim in solem et puluerem non ut e militari tabernaculo, sed ut e Theophrasti doctissumi hominis umbraculis. (38) Hic primus inflexit orationem et eam mollem teneramque reddidit et suauis, sicut fuit, uideri maluit quam grauis, sed suauitate ea, qua perfunderet animos, non qua perfringeret; (et) tantum ut memoriam concinnitatis suae, non, quemadmodum de Pericle scripsit Eupolis, cum delectatione aculeos etiam relinqueret in animis eorum, a quibus esset auditus.

[10] X. (39) Videsne igitur, Brute, in ea ipsa urbe, in qua et nata et alta sit eloquentia, quam ea sero prodierit in lucem? si quidem ante Solonis aetatem et Pisistrati de nullo ut diserto memoriae proditum est. at hi nada de ornado, fosse pela gravidade das palavras, fosse pela dos pensamentos, que pudesse ser mais sublime. [36] Muito próximo a ele estava Hipérides, e também Ésquines, Licurgo, Dinarco e também Demades, de quem não restam escritos, e muitos outros. De fato, essa geração produziu tal abundância; e, conforme a minha opinião, aquela vitalidade e a pureza do sangue perduraram até essa geração de oradores, na qual havia uma beleza natural, não afetada. [37] Com efeito, o jovem Demétrio de Falera sucedeu a esses mais velhos, o mais erudito de todos eles é bem verdade, mas não tão instruído para o campo de batalha quanto para os exercícios da palestra. Desse modo, antes deleitava os atenienses do que inflamava. É que ele enfrentara a luz do sol e a poeira não como se saísse de uma tenda militar, mas como se saísse das sombras da escola do cultivadíssimo Teofrasto. [38] Ele foi o primeiro a modular o discurso e a torná-lo delicado e maleável, preferindo parecer agradável, tal como era, do que veemente, porém aquele modo de agradar que banha os ânimos não que os encharca, tanto que deixava nos ânimos de quem o tinha escutado a lembrança de sua elegância, não juntando ao deleite os aguilhões do discurso, como descreveu Êupolis acerca de Péricles.

[39] Você percebe, então, que até mesmo naquela cidade em que a eloquência nasceu e foi nutrida quão tarde ela veio à luz? Se é verdade que antes da geração de Sólon e Pisístrato não há registro de nenhum orador habilidoso. Mas eles, 
quidem, ut populi Romani aetas est, senes, ut Atheniensium saecla numerantur, adulescentes debent uideri. nam etsi Seruio Tullio regnante uiguerunt, tamen multo diutius Athenae iam erant, quam est Roma ad hodiernum diem. nec tamen dubito quin habuerit uim magnam semper oratio. (40) Neque enim iam Troicis temporibus tantum laudis in dicendo Ulixi tribuisset Homerus et Nestori, quorum alterum uim habere uoluit, alterum suauitatem, nisi iam tum esset honos eloquentiae; neque ipse poeta hic tam (idem) ornatus in dicendo ac plane orator fuisset. cuius etsi incerta sunt tempora, tamen annis multis fuit ante Romulum; si quidem non infra superiorem Lycurgum fuit, a quo est disciplina Lacedaemoniorum astricta legibus. (41) Sed studium eius generis maiorque uis agnoscitur in Pisistrato. denique hunc proximo saeculo Themistocles insecutus est, ut apud nos, perantiquus, ut apud Athenienses, non ita sane uetus. fuit enim regnante iam Graecia, nostra autem ciuitate non ita pridem dominatu regio liberata. nam bellum Volscorum illud grauissimum, cui Coriolanus exsul interfuit, eodem fere tempore quo Persarum bellum fuit, similisque fortuna clarorum uirorum; (42) Si quidem uterque, cum ciuis egregius fuisset, populi ingrati pulsus iniuria se ad hostes contulit conatumque iracundiae suae morte na verdade, que, para a idade do povo romano, são velhos, na contagem das gerações atenienses, devem ser considerados jovens. Com efeito, embora eles tivessem florescido no reinado de Sérvio Túlio, Atenas já existia há muito mais tempo do que Roma até os dias de hoje. E, no entanto, não tenho dúvida de que a palavra sempre teve grande poder. [40] E, de fato, já na época de Tróia, Homero não teria atribuído tanto valor à oratória de Ulisses e Nestor, de quem queria sublinhar o vigor do primeiro e a elegância do segundo, se já não existisse então o prestígio da eloquência, nem mesmo o próprio poeta teria se mostrado tão ornado em seu discurso e um verdadeiro orador. Embora não se saiba ao certo em que época, viveu muitos anos antes de Rômulo, se é verdade que não foi posterior ao primeiro Licurgo, que sistematizou em leis o modo de vida dos espartanos. [41] Porém se reconhece um entusiasmo pela eloquência e uma maior eficácia em Pisístrato. Enfim, depois dele no século seguinte veio Temístocles, entre nós é muito antigo, entre os atenienses, não é tão antigo assim. Pois viveu quando a Grécia já exercia o reinado, ao passo que nossa cidade havia sido libertada do domínio dos reis não havia muito tempo. Com efeito, aquela duríssima guerra contra os volscos, em que participou Coriolano exilado, foi quase contemporânea à guerra contra os persas, e foi semelhante à sorte desses ilustres varões. [42] Se é verdade que ambos, conquanto fossem cidadãos importantes, banidos por injustiça do povo 
sedauit. nam etsi aliter apud te est, Attice, de Coriolano, concede tamen ut huic generi mortis potius adsentiar.

[11] XI. At ille ridens: tuo uero, inquit, arbitratu; quoniam quidem concessum est rhetoribus ementiri in historiis, ut aliquid dicere possint argutius. ut enim tu nunc de Coriolano, sic Clitarchus, sic Stratocles de Themistocle finxit. (43) Nam quem Thucydides, qui et Atheniensis erat et summo loco natus summusque uir et paulo aetate posterior, tantum morbo mortuum scripsit et in Attica clam humatum, addidit fuisse suspicionem ueneno sibi consciuisse mortem: hunc isti aiunt, cum taurum immolauisset, excepisse sanguinem patera et eo poto mortuum concidisse. hanc enim mortem rhetorice et tragice ornare potuerunt; illa mors uolgaris nullam praebebat materiem ad ornatum. quare quoniam tibi ita quadrat, omnia fuisse Themistocli paria et Coriolano, pateram quoque a me sumas licet, praebebo etiam hostiam, ut Coriolanus sit plane alter Themistocles.

(44) Sit sane, inquam, ut lubet, de isto; et ego cautius posthac historiam attingam te audiente, quem re- ingrato se refugiaram junto aos inimigos e aplacaram o ímpeto de sua ira com a própria morte. Apesar de você, Ático, registrar isso de modo diferente acerca de Coriolano, permita que eu concorde antes com este tipo de morte.

E ele rindo disse: - Como você quiser, uma vez que é permitido aos rétores mentir em seus relatos históricos para poderem dizer algo com maior expressividade. Pois do mesmo modo que você faz agora com Coriolano, tanto Clitarco como Estrátocles também forjaram um relato sobre a morte de Temístocles [43] Com efeito, sobre ele Tucídides, que era ateniense, nascido de nobre estirpe e homem excelente, pouco posterior aos acontecimentos, escreveu somente que morreu de enfermidade e que foi sepultado clandestinamente na Ática, acrescentando que houve suspeita de que ele suicidou-se por envenenamento. Eles, por outro lado, dizem que durante o sacrifício de um touro, ele teria recolhido o sangue numa pátera e, depois de bebê-lo, teria caído morto. É que assim eles podiam embelezar o relato da morte de uma maneira retórica e trágica. Aquela morte banal não oferecia nenhuma matéria para embelezamento. Por essa razão, já que quadra ao seu relato que tudo tenha sido igual em Temístocles e Coriolano, você pode receber de mim também a pátera, oferecerei ainda a vítima do sacrifício, para que Coriolano seja realmente um segundo Temístocles.

[44] — Sim, respondi, seja como você preferir com relação a ele; de minha parte, daqui pra frente falarei com mais cuidado 
rum Romanarum auctorem laudare possum religiosissumum. sed tum fere Pericles Xanthippi filius, de quo ante dixi, primus adhibuit doctrinam; quae quamquam tum nulla erat dicendi, tamen ab Anaxagora physico eruditus exercitationem mentis a reconditis abstrusisque rebus ad causas forensis popularisque facile traduxerat. huius suauitate maxume hilaratae Athenae sunt, huius ubertatem et copiam admiratae eiusdem uim dicendi terroremque timuerunt. [12] XII. (45) Haec igitur aetas prima Athenis oratorem prope perfectum tulit. nec enim in constituentibus rem publicam nec in bella gerentibus nec in impeditis ac regum dominatione deuinctis nasci cupiditas dicendi solet. pacis est comes otique socia et iam bene constitutae ciuitatis quasi alumna quaedam eloquentia. (46) Itaque, ait Aristoteles, cum sublatis in Sicilia tyrannis res priuatae longo interuallo iudiciis repeterentur, tum primum, quod esset acuta illa gens et controuersiae nata, artem et praecepta Siculos Coracem et Tisiam conscripsisse - nam antea neminem solitum uia nec arte, sed accurate tamen et descripte plerosque dicere - ; scriptasque fuisse et paratas a Protagora rerum illustrium disputationes, quae nunc communes appellantur loci. (47) Quod idem fecisse Gorgiam, cum singularum rerum laudes uituperationesque cons- sobre história tendo você como ouvinte, alguém que eu posso elogiar como a mais escrupulosa autoridade em história romana. Mas, quase na mesma época, Péricles, filho de Xantipo, de que falei antes, foi o primeiro a aplicar o conhecimento teórico, ainda que não fosse o oratório, porém, instruído pelo físico Anaxágoras, teve facilidade para transferir o exercício intelectual de assuntos obscuros e abstrusos para as causas forenses e assembleias populares. Atenas se regozijou particularmente com sua doçura, admirou sua riqueza e abundância mas também tremeu diante de sua terrível força oratória. [45] Essa época, então, produziu pela primeira vez em Atenas um orador quase perfeito. É que não é na fundação de uma república, nem na condução de uma guerra, nem quando se é impedido e submetido à tirania dos reis que costuma nascer o amor à oratória. Companheira da paz e aliada da tranquilidade, a eloquência é como que rebento de uma cidade já bem constituída. [46] Assim, Aristóteles afirma que depois da expulsão dos tiranos da Sicília as propriedades particulares, após longo período de interrupção, passaram a ser reclamadas em tribunal, então pela primeira vez, pois aquela gente era perspicaz e nascida para a controvérsia, os sicilianos Córax e Tísias redigiram um manual de preceitos - de fato, antes disso ninguém costumava discursar com método e técnica, muito embora alguns o fizessem com zelo e precisão -, e afirma também que Protágoras escreveu e elaborou discussões sobre temas notáveis, que 
cripsisset, quod iudicaret hoc oratoris esse maxume proprium, rem augere posse laudando uituperandoque rursus adfligere; huic Antiphontem Rhamnusium similia quaedam habuisse conscripta; quo neminem umquam melius ullam orauisse capitis causam, cum se ipse defenderet se audiente, locuples auctor scripsit Thucydides. (48) Nam Lysiam primo profiteri solitum artem esse dicendi; deinde, quod Theodorus esset in arte subtilior, in orationibus autem ieiunior, orationes eum scribere aliis coepisse, artem remouisse. similiter Isocraten primo artem dicendi esse negauisse, scribere autem aliis solitum orationes, quibus in iudiciis uterentur; sed cum ex eo, quia quasi committeret contra legem 'quo quis iudicio circumueniretur', saepe ipse in iudicium uocaretur, orationes aliis destitisse scribere totumque se ad artes componendas transtulisse.

[13] XIII. (49) Et Graeciae quidem oratorum partus atque fontis uides, ad nostrorum annalium rationem ueteres, ad ipsorum sane recentes. nam ante quam delectata est Atheniensium ciuitas hac laude dicendi, multa iam memorabilia et in agora são chamados de lugares comuns; [47] que Górgias fez o mesmo ao registrar por escrito elogios e vitupérios sobre temas particulares, pois ele julgava que a principal característica do orador é a capacidade de engrandecer uma coisa elogiando-a e, inversamente, depreciá-la vituperando-a; que Antifonte de Ramnúsia teria escrito alguns textos semelhantes, sobre ele, Tucídides, autor digno de fé, que ouviu Antifonte fazer sua própria defesa, escreveu que ninguém jamais havia defendido tão bem uma causa capital. [48] Quanto a Lísias, num primeiro momento teria tido hábito de afirmar que havia uma arte oratória, em seguida, visto que Teodoro era mais refinado na teoria, porém mais árido nos discursos, ele teria começado a escrever discursos em nome de outros, abandonando a teoria. De modo semelhante, Isócrates num primeiro momento teria afirmado que não havia uma arte oratória, e costumava escrever discursos para que outros usassem em tribunal, mas como muitas vezes era chamado em juízo por isso, pois teria, por assim dizer, agido contra a lei que condena o uso de chicanas nos processos, teria desistido de escrever discursos para outras pessoas e passado a se dedicar totalmente à composição de escritos teóricos.

[49] Então, você está vendo, com relação à Grécia, o nascimento e a origem dos oradores, antigos segundo a contagem de nossos anais, bem recentes segundo a deles. De fato, a cidade de Atenas, antes de se deleitar com a glória oratória, já havia conseguido muitos feitos memoráveis tanto 
domesticis et in bellicis rebus effecerat. hoc autem studium non erat commune Graeciae, sed proprium Athenarum. (50) Quis enim aut Argiuum oratorem aut Corinthium aut Thebanum scit fuisse temporibus illis? nisi quid de Epaminonda docto homine suspicari lubet. Lacedaemonium uero usque ad hoc tempus audiui fuisse neminem. Menelaum ipsum dulcem illum quidem tradit Homerus, sed pauca dicentem. breuitas autem laus est interdum in aliqua parte dicendi, in uniuersa eloquentia laudem non habet. (51) At uero extra Graeciam magna dicendi studia fuerunt maxumique huic laudi habiti honores illustre oratorum nomen reddiderunt. nam ut semel e Piraeo eloquentia euecta est, omnis peragrauit insulas atque ita peregrinata tota Asia est, ut se externis oblineret moribus omnemque illam salubritatem Atticae dictionis et quasi sanitatem perderet ac loqui paene dedisceret. hinc Asiatici oratores non contemnendi quidem nec celeritate nec copia, sed parum pressi et nimis redundantes; Rhodii saniores et Atticorum similiores. (52) Sed de Graecis hactenus; et enim haec ipsa forsitan fuerint non necessaria. Tum Brutus: ista uero, inquit, quam necessaria fuerint non facile dixerim; iucunda certe mihi fuerunt neque solum non longa, sed etiam breuiora quam uellem. Optime, inquam, sed na paz como na guerra. No entanto, esse interesse não era comum a toda Grécia, mas característico de Atenas. [50] De fato, quem conhece um orador de Argos ou de Corinto ou de Tebas que tenha vivido naquela época? A não ser que bem nos pareça fazer alguma suposição acerca do homem cultivado que foi Epaminôndas. Por outro lado, até os dias de hoje não ouvi falar da existência de nenhum orador espartano. O próprio Menelau, segundo Homero, é bem verdade, discursava com doçura, mas com poucas palavras. Ora, a brevidade às vezes é um mérito em certas partes do discurso, não é um mérito na eloquência como um todo. [51] Na verdade, foi grande o entusiasmo pela oratória fora da Grécia e as grandiosas honras atribuídas à excelência nessa prática tornaram ilustre o nome dos oradores. De fato, assim que a eloquência foi exportada do Pireu, viajou por todas as ilhas e percorreu tanto por toda Ásia que se contaminou de hábitos estrangeiros e perdeu toda aquela salubridade e, por assim dizer, sanidade da dicção ática, quase desaprendendo a falar. Foi então que surgiram os oradores asiáticos não desprezíveis pela fluência nem pela copiosidade, é certo, mas pouco sóbrios e demasiado redundantes; os da ilha de Rodes são mais sóbrios e mais semelhantes aos áticos. [52] Mas basta de gregos, e a verdade é que isso talvez não tivesse sido necessário. Então, Bruto disse: - O fato é que não saberia dizer o quanto era necessário, foi seguramente agradável para mim, e não apenas não foi uma exposição extensa mas tam- 
ueniamus ad nostros, de quibus difficile est plus intellegere quam quantum ex monumentis suspicari licet.

\section{[14] XIV. (53) Quis enim putet} aut celeritatem ingeni L. Bruto illi nobilitatis uestrae principi defuisse? qui de matre sauianda ex oraculo Apollinis tam acute arguteque coniecerit; qui summam prudentiam simulatione stultitiae texerit; qui potentissimum regem clarissumi regis filium expulerit ciuitatemque perpetuo dominatu liberatam magistratibus annuis legibus iudiciisque deuinxerit; qui collegae suo imperium abrogauerit, ut e ciuitate regalis nominis memoriam tolleret: quod certe effici non potuisset, nisi esset oratione persuasum. (54) Videmus item paucis annis post reges exactos, cum plebes prope ripam Anionis ad tertium miliarium consedisset eumque montem, qui Sacer appellatus est, occupauisset, M. Valerium dictatorem dicendo sedauisse discordias, eique ob eam rem honores amplissumos habitos et eum primum ob eam ipsam causam Maxumum esse appellatum. ne L. Valerium quidem Potitum arbitror non aliquid potuisse dicendo, qui post decemuiralem inuidiam plebem in patres incitatam legibus et contionibus suis mitigauerit. (55) Possumus Appium Claudium suspicari disertum, quia bém foi mais breve do que eu desejava. - Muito bem, continuei, mas vamos aos nossos, sobre os quais é difícil saber mais do que se pode conjecturar pelos registros escritos.

[53] Ora, quem pode acreditar que faltava presteza de engenho a Lúcio Bruto, o célebre fundador de sua nobre estirpe, ou mesmo... Ele que interpretou com sagacidade e perspicácia o sentido do oráculo de Apolo sobre o beijo da mãe; ele que escondeu uma extrema inteligência sob a aparência de estupidez; ele que baniu um rei tão poderoso, filho de um rei tão ilustre, e que sujeitou a cidade, libertada da tirania ininterrupta, a magistraturas anuais, leis e tribunais; ele que revogou o poder de seu colega, para que a cidade suprimisse a memória do título de rei; o que certamente não teria conseguido sem a persuasão do discurso. [54] Constatamos do mesmo modo que poucos anos depois da expulsão dos reis, quando a plebe acampou a três milhas próximo à margem do Ânio e ocupou aquele monte, chamado de Sacro, o ditador Marco Valério aplacou as discórdias com a palavra, e a ele, por isso, foram atribuídas as mais distintas honras e, pela mesma razão, ele foi o primeiro a ser denominado Máximo. Penso que nem mesmo a Lúcio Valério Potito faltava alguma capacidade oratória, ele que depois da tirania dos decênviros aplacou o ódio da plebe contra os patrícios com suas leis e discursos perante o povo. [55] Podemos supor que Ápio Claudio era bem articulado, porque dissuadiu o senado já 
senatum iamiam inclinatum a Pyrrhi pace reuocauerit; possumus C. Fabricium, quia sit ad Pyrrhum de captiuis recuperandis missus orator; Ti. Coruncanium, quod ex pontificum commentariis longe plurumum ingenio ualuisse uideatur; M. Curium, quod is tribunus plebis interrege Appio Caeco diserto homine comitia contra leges habente, cum de plebe consulem non accipiebat, patres ante auctores fieri coegerit; quod fuit permagnum nondum lege Maenia lata. (56) Licet aliquid etiam de M- Popilli ingenio suspicari, qui cum consul esset eodemque tempore sacrificium publicum cum laena faceret, quod erat flamen Carmentalis, plebei contra patres concitatione et seditione nuntiata, ut erat laena amictus ita uenit in contionem seditionemque cum auctoritate tum oratione sedauit. sed eos oratores habitos esse aut omnino tum ullum eloquentiae praemium fuisse nihil sane mihi legisse uideor: tantummodo coniectura ducor ad suspicandum. (57) Dicitur etiam C. Flaminius, is qui tribunus plebis legem de agro Gallico et Piceno uiritim diuidendo tulerit, qui consul apud Tarsumennum sit interfectus, ad populum ualuisse dicendo. Q- etiam Maxumus Verrucosus orator habitus est temporibus illis et $\mathrm{Q}$. Metellus, is qui bello $\mathrm{Pu}-$ nico secundo cum L. Veturio Philone consul fuit. propenso a fazer a paz com Pirro. Podemos pensar o mesmo de Caio Fabrício, porque foi enviado como embaixador para tratar do resgate de prisioneiros; de Tibério Coruncânio, pois nos comentários dos pontífices parece ter possuído um engenho de imenso valor; de Mânio Cúrio, pois em seu tribunado da plebe diante da oposição do interrei Ápio Cego, homem bem articulado, que presidindo as eleições não aceitava, contra a lei, um cônsul da plebe, fez com que os senadores ratificassem antes as eleições, feito considerável pois não havia sido aprovada ainda a lei Mênia. [56] Poderia fazer alguma conjectura sobre o engenho de Marco Popílio, quando era cônsul e na mesma ocasião em que fazia um sacrifício público com o manto sacerdotal, pois era flâmine de Carmenta, quando lhe foi dada a notícia de um tumulto e sedição da plebe contra os patrícios, vestido como estava com o manto, chegou à assembleia e apaziguou a sedição tanto com sua autoridade como com sua palavra. Mas que eles fossem considerados oradores ou então que, de modo geral, houvesse alguma recompensa para a eloquência acredito não ter lido realmente nada sobre isso: o que me faz suspeitar é apenas uma conjectura. [57] Também se diz que Caio Flamínio, aquele tribuno da plebe que propôs uma lei sobre a divisão per-capita das terras da Gália e de Piceno, que quando era cônsul foi morto em Trasumeno, tinha uma palavra influente sobre o povo. Também Quinto Máximo Verrucoso foi considerado orador naquele tempo, bem como Quinto 
[15] XV. Quem uero exstet et de quo sit memoriae proditum eloquentem fuisse et ita esse habitum, primus est M. Cornelius Cethegus, cuius eloquentiae est auctor et idoneus quidem mea sententia Q. Ennius, praesertim cum et ipse eum audiuerit et scribat de mortuo; ex quo nulla suspicio est amicitiae causa esse mentitum. (58) Est igitur sic apud illum in nono, ut opinor, an-

nali: additur orator Cornelius suauiloquenti ore Cethegus Marcus Tuditano conlega Marci filius - . Et

oratorem appellat et suauiloquentiam tribuit, quae nunc quidem non tam est in plerisque: latrant enim iam quidam oratores, non loquuntur; sed est ea laus eloquentiae certe

maxuma: is dictust ollis popularibus olim, qui tum uiuebant homines atque aeuum agitabant, flos delibatus populi - (59) Probe uero;

ut enim hominis decus ingenium, sic ingeni ipsius lumen est eloquentia, qua uirum excellentem praeclare tum illi homines florem populi esse

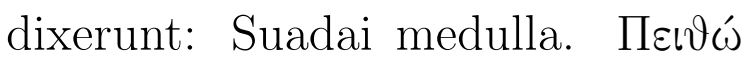
quam uocant Graeci, cuius effector est orator, hanc Suadam appellauit
Metelo, aquele que foi cônsul junto com Lúcio Vetúrio Fílon durante a segunda guerra púnica.

Mas de quem há evidências e de quem a história testemunha a eloquência e que assim foi considerado, o primeiro é Marco Cornélio Cetego, de cuja eloquência é testemunha, e competente, pelo menos a meu ver, Quinto Ênio, sobretudo porque tanto pode ouvi-lo pessoalmente como escreveu depois dele morto, o que não gera nenhuma suspeita que tivesse mentido por amizade. [58] Ora, assim está no nono livro, me parece, dos anais:

"Ao colega Tuditano acrescenta-se Marco Cornélio Cetego, filho de Marco, orador de voz suaveloquente."

não apenas o chama de orador mas também lhe atribui uma suaveloquência, que, ao menos agora, não é tão comum: é que alguns oradores latem, não falam, mas este é certamente o maior elogio da eloquência:

"Ele foi chamado por seus compatriotas da época,

homens que então viviam e passavam os dias, a flor seleta do povo..."

[59] Magnífico. É que assim como a glória do homem é o engenho, a luz do próprio engenho é a eloquência, esse varão que nela atingiu a excelência foi chamado pelos homens de então de "a flor do povo".

"a alma da Persuasão."

Aquela que os gregos chamam de

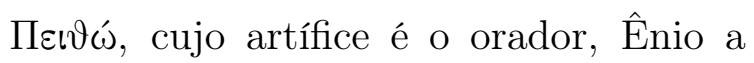
chamou de Persuasão. Ele pretende que 
Ennius; eius autem Cethegum medullam fuisse uult, ut, quam deam in Pericli labris scripsit Eupolis sessitauisse, huius hic medullam nostrum oratorem fuisse dixerit. (60) At hic Cethegus consul cum P. Tuditano fuit bello Punico secundo quaestorque his consulibus M. Cato modo plane annis cxl ante me consulem; et id ipsum nisi unius esset Enni testimonio cognitum, hunc uetustas, ut alios fortasse multos, obliuione obruisset. illius autem aetatis qui sermo fuerit ex Naeuianis scriptis intellegi potest. his enim consulibus, ut in ueteribus commentariis scriptum est, Naeuius est mortuus; quamquam Varro noster diligentissumus inuestigator antiquitatis putat in hoc erratum uitamque Naeui producit longius. nam Plautus $P$. Claudio L. Porcio uiginti annis post illos quos ante dixi consulibus mortuus est Catone censore. (61) Hunc igitur Cethegum consecutus est aetate Cato, qui annis ix post eum fuit consul. eum nos ut perueterem habemus, qui L. Marcio M. Manilio consulibus mortuus est, annis lxxxui ipsis ante me consulem.

[16] XVI. Nec uero habeo quemquam antiquiorem, cuius quidem scripta proferenda putem, nisi quem Appi Caeci oratio haec ipsa de Pyrrho et nonnullae mortuorum laudationes forte delectant. (62) Et hercu-
Cetego era alma dessa deusa, que como escreveu Êupolis costumava tomar assento nos lábios de Péricles, e ele disse que nosso orador havia sido a alma dela. [60] Ora, esse Cetego foi cônsul com Públio Tuditano durante a segunda guerra púnica e Marco Catão foi questor no consulado deles precisamente 140 anos antes de meu consulado, e se isso não tivesse sido conhecido pelo testemunho único de Ênio, o passar do tempo, como provavelmente aconteceu a muitos outros, o teria sepultado no esquecimento. E a maneira de se exprimir que era vigente nessa época se pode depreender dos escritos de Névio. Com efeito, Névio morreu no consulado deles, conforme está escrito nos comentários antigos, embora nosso caro Varrão, diligentíssimo investigador da antiguidade, considere que haja um erro nisso, prolongando um pouco mais a vida de Névio. De fato, Plauto morreu no consulado de Públio Cláudio e Lúcio Pórcio, vinte anos depois dos cônsules que mencionei antes, quando Catão era censor. [61] Então, a este Cetego se seguiu, no que concerne à geração, Catão, que foi cônsul nove anos depois dele. Nós o consideramos muito antigo, ele que morreu no consulado de Lúcio Márcio e Mânio Manílio, exatamente oitenta e seis anos antes de meu consulado.

E a verdade é que não conheço ninguém mais antigo, ninguém pelo menos cujos escritos eu julgue dignos de menção, a não ser que acaso agrade aquele mesmo discurso de Ápio Cego sobre Pirro e alguns elogios aos mortos. [62] E certamente eles 
les eae quidem exstant: ipsae enim familiae sua quasi ornamenta ac monumenta seruabant et ad usum, si quis eiusdem generis occidisset, et ad memoriam laudum domesticarum et ad illustrandam nobilitatem suam. quamquam his laudationibus historia rerum nostrarum est facta mendosior. multa enim scripta sunt in eis quae facta non sunt: falsi triumphi, plures consulatus, genera etiam falsa et ad plebem transitiones, cum homines humiliores in alienum eiusdem nominis infunderentur genus; ut si ego me a M. Tullio esse dicerem, qui patricius cum Ser. Sulpicio consul anno x post exactos reges fuit. (63) Catonis autem orationes non minus multae fere sunt quam Attici Lysiae, cuius arbitror plurumas esse - est enim Atticus, quoniam certe Athenis est et natus et mortuus et functus omni ciuium munere, quamquam Timaeus eum quasi Licinia et Mucia lege repetit Syracusas - , et quodam modo est nonnulla in iis etiam inter ipsos similitudo: acuti sunt, elegantes faceti breues; sed ille Graecus ab omni laude felicior. (64) Habet enim certos sui studiosos, qui non tam habitus corporis opimos quam gracilitates consectentur; quos, ualetudo modo bona sit, tenuitas ipsa delectat - quamquam in Lysia sunt saepe etiam lacerti, sic ut (et) fieri nihil possit ualentius; uerum est certe genere toto strigosior — , sed habet ainda existem: as próprias famílias conservavam como honrarias, por assim dizer, e como documentos para serem utilizados se alguém da mesma linhagem morre e para memória das glórias domésticas, bem como para abrilhantar sua própria nobreza. Todavia, com esses elogios a nossa história foi muito falseada. De fato, muita coisa foi registrada nela que não aconteceu: falsos triunfos, inúmeros consulados, também falsas genealogias e passagens para a plebe, quando homens mais humildes eram introduzidos em uma outra família de mesmo nome, como se eu afirmasse ser descendente de Mânio Túlio, patrício que foi cônsul com Sérvio Sulpício dez anos depois da expulsão dos reis. [63] Mas os discursos de Catão não são tão menos numerosos que os do ático Lísias, de quem acredito que há muitíssimos - ele é realmente ático, uma vez que não só nasceu em Atenas mas também morreu, bem como desempenhou todo dever de cidadão, embora Timeu como que aplicando a lei Licínia e Múcia o repatria a Siracusa -, e de certo modo em seus discursos também há alguma semelhança entre eles: são agudos, elegantes, espitiruosos, breves, mas o grego é mais afortunado quanto à reputação em geral. [64] De fato, ele tem os seus partidários, que procuram imitar não tanto a forma bem nutrida do corpo quanto a magreza, a eles, contanto que haja boa saúde, agrada a própria esbelteza - embora muitas vezes haja em Lísias também robustez, de tal modo que nada possa ser mais vigoroso, porém no todo $^{6}$ é certamente um orador muito ma- 
tamen suos laudatores, qui hac ipsa eius subtilitate admodum gaudeant.

\section{[17] XVII. (65) Catonem uero} quis nostrorum oratorum, qui quidem nunc sunt, legit? aut quis nouit omnino? at quem uirum, di boni! mitto ciuem aut senatorem aut imperatorem: oratorem enim hoc loco quaerimus: quis illo grauior in laudando, acerbior in uituperando, in sententiis argutior, in docendo edisserendoque subtilior? refertae sunt orationes amplius centum quinquaginta, quas quidem adhuc inuenerim et legerim, et uerbis et rebus inlustribus. licet ex his eligant ea quae notatione et laude digna sint: omnes oratoriae uirtutes in eis reperientur. (66) Iam uero Origines eius quem florem aut quod lumen eloquentiae non habent? amatores huic desunt, sicuti multis iam ante saeclis et Philisto Syracusio et ipsi Thucydidi. nam ut horum concisis sententiis, interdum etiam non satis apertis (autem) cum breuitate tum nimio acumine, officit Theopompus elatione atque altitudine orationis suae - quod idem Lysiae Demosthenes - , sic Catonis luminibus obstruxit haec posteriorum quasi exaggerata altius oratio. (67) Sed ea in nostris inscitia est, quod hi ipsi, qui in Graecis antiquitate delectantur eaque subtilitate, quam Atticam appellant, hanc in Catone ne nouerunt quidem. Hyperidae uolunt cilento - , contudo tem seus admiradores, que muito se comprazem justamente com a secura dele.

[65] Mas quanto a Catão, quem de nossos oradores o lê, quem dos que agora vivem, quero dizer? Ou então, quem simplesmente o conhece? E que homem, ó bons deuses! Deixo de lado o cidadão, o senador ou o general. Pois é o orador que examinamos aqui: quem era mais majestoso no elogio, mais acerbo no vitupério, mais penetrante nos pensamentos, mais preciso na demonstração e na exposição? Seus discursos, mais de cento e cinquenta, pelo menos os que encontrei e li até agora, estão repletos tanto de palavras como de pensamentos brilhantes. É possível recolher neles o que for digno de nota e de elogio, todas as virtudes oratórias se encontrarão neles. [66] Quanto às suas Origens, que flor ou que luz da eloquência não constam lá? Faltam-lhe os apreciadores, assim como há muitos séculos atrás já ocorreu tanto a Filisto de Siracusa como ao próprio Tucídides. De fato, assim como a concisão de seus pensamentos, muitas vezes também não muito claros, seja pela brevidade, seja pela excessiva agudeza, foi superada por Teopompo pela elevação e pela eminência de seu discurso - o mesmo fez Demóstenes a Lísias -, assim também o esplendor de Catão foi ofuscado pela oratória posterior, como que por uma amplificação mais elevada. [67] Mas a ignorâcia entre os nossos conterrâneos é tal, que eles mesmos, que se comprazem com a maneira antiga e aquela simplicidade dos gregos que eles 
esse et Lysiae. laudo: sed cur nolunt Catones? (68) Attico genere dicendi se gaudere dicunt. sapienter id quidem; atque utinam imitarentur nec ossa solum, sed etiam sanguinem! gratum est tamen, quod uolunt. cur igitur Lysias et Hyperides amatur, cum penitus ignoretur Cato? antiquior est huius sermo et quaedam horridiora uerba. ita enim tum loquebantur. id muta, quod tum ille non potuit, et adde numeros et, ut aptior sit oratio, ipsa uerba compone et quasi coagmenta, quod ne Graeci quidem ueteres factitauerunt: iam neminem antepones Catoni. Ornari orationem Graeci putant, si uerborum immutationibus utantur, quos appellant трótous, et sententiarum orationisque formis, quae uocant $\sigma \chi \hat{n} \mu \alpha \tau \alpha$ : non ueri simile est quam sit in utroque genere et creber et distinctus Cato.

[18] XVIII. Nec uero ignoro nondum esse satis politum hunc oratorem et quaerendum esse aliquid perfectius; quippe cum ita sit ad nostrorum temporum rationem uetus, ut nullius scriptum exstet dignum quidem lectione, quod sit antiquius. sed maiore honore in omnibus artibus quam in hac una arte dicendi uersatur antiquitas. (70) Quis enim eo- denominam ática, sequer reconheceram-na em Catão. Querem ser como Hipérides e Lísias. Louvo isso. Mas por que não querem ser como Catão? [68] Afirmam se comprazer com o gênero oratório ático. E o fazem muito sabiamente. E quem dera eles imitassem não só os ossos mas também o sangue. Todavia é bem vindo o que procuram. Então, por que são estimados Lísias e Hipérides, enquanto Catão é inteiramente ignorado? A sua linguagem é mais antiga e algumas palavras mais rústicas. Pois assim falavam na época. Mude aquilo que ele então não podia fazer, e acrescente o ritmo, e, para que o discurso fique mais coeso, arranje e, por assim dizer, cimente as próprias palavras, o que nem mesmo os gregos antigos costumavam fazer: então não se poderá colocar ninguém à frente de Catão. [69] Os gregos consideram que o discurso é ornado, quando utilizam as transposições de palavras, que eles denominam tpótous [tropous], e as figuras de pensamentos e de palavra, que eles chamam de $\sigma$ xń $\mu \alpha \tau \alpha$ [schémata]: é incrível o quanto Catão era não só abundante como também preciso em ambas as categorias.

$\mathrm{Na}$ verdade, não ignoro que ele ainda não é um orador suficientemente refinado e que se deva procurar algo mais completo; porque ele é tão antigo em nossa contagem do tempo que não resta nenhum escrito mais antigo, pelo menos de ninguém que seja digno de leitura. Mas a antiguidade goza de maior prestígio em todas as artes, menos nesta singular arte oratória. [70] De fato, quem dos que observam as artes 
rum qui haec minora animaduertunt non intellegit Canachi signa rigidiora esse quam ut imitentur ueritatem? Calamidis dura illa quidem, sed tamen molliora quam Canachi; nondum Myronis satis ad ueritatem adducta, iam tamen quae non dubites pulchra dicere; pulchriora Polycliti et iam plane perfecta, ut mihi quidem uideri solent. similis in pictura ratio est: in qua Zeuxim et Polygnotum et Timanthem et eorum, qui non sunt usi plus quam quattuor coloribus, formas et liniamenta laudamus; at in Aetione Nicomacho Protogene Apelle iam perfecta sunt omnia. (71) Et nescio an reliquis in rebus omnibus idem eueniat: nihil est enim simul et inuentum et perfectum; nec dubitari debet quin fuerint ante Homerum poetae, quod ex eis carminibus intellegi potest, quae apud illum et in Phaeacum et in procorum epulis canuntur. quid, nos-

tri veteres uersus ubi sunt? quos olim Fauni uatesque canebant, cum neque Musarum scopulos nec dicti studiosus quisquam erat ante hunc

- ait ipse de se nec mentitur in gloriando: sic enim sese res habet. nam et Odyssia Latina est sic (in) tamquam opus aliquod Daedali et Liuianae fabulae non satis dignae quae iterum legantur. (72) Atqui hic Liuius (qui) primus fabulam C. Claudio Ca- menores não compreende que as estátuas de Cânaco são rígidas demais para imitar a realidade? As de Cálamis ainda são duras, embora tenham mais leveza que as de Cânaco. Embora as de Míron não sejam bastante próximas à realidade, todavia não hesitaríamos em chamá-las de belas. As de Policleto são mais belas e, pelo menos a meu ver, já plenamente amadurecidas. O raciocínio é semelhante na pintura: na qual louvamos as formas e os contornos de Zêuxis, Polignoto, Timante e dos que não usavam mais do que quatro cores, mas em Aécion, Nicômaco, Protógenes, Apeles tudo já está amadurecido. [71] E talvez aconteça o mesmo em todas as outras coisas: pois nada é ao mesmo tempo inventado e amadurecido, e não se deve duvidar de que houve poetas antes de Homero, como se pode depreender daqueles poemas que em sua obra são cantados tanto nos banquetes dos Feácios como nos pretendentes. Ora, onde estão nossos antigos versos?

que outrora cantavam os Faunos e os vates,

quando nem os rochedos das Musas nem ninguém antes de mim era tão entusiasmado pelas letras.

ele diz isso de si mesmo e não mente ao vangloriar-se: pois esse é realmente o caso. Com efeito, por um lado, a Odisseia latina é, por assim dizer, como uma obra de Dédalo, por outro lado, as peças de Lívio não são dignas de serem lidas mais de uma vez. [72] No entanto, foi Lívio quem primeiro representou uma peça de 
eci filio et M. Tuditano consulibus docuit anno ipso ante quam natus est Ennius, post Romam conditam autem quarto decumo et quingentesimo, ut hic ait, quem nos sequimur. est enim inter scriptores de numero annorum controuersia. Accius autem a Q. Maxumo quintum consule captum Tarento scripsit Liuium annis xxx post quam eum fabulam docuisse et Atticus scribit et nos in antiquis commentariis inuenimus; (73) Docuisse autem fabulam annis post xi, C. Cornelio Q. Minucio consulibus ludis Iuuentatis, quos Salinator Senensi proelio uouerat. in quo tantus error Acci fuit, ut his consulibus xl annos natus Ennius fuerit: quoi aequalis fuerit Liuius, minor fuit aliquanto is, qui primus fabulam dedit, quam ii, qui multas docuerant ante hos consules, et Plautus et Naeuius.

[19] XIX. (74) Haec si minus apta uidentur huic sermoni, Brute, Attico adsigna, qui me inflammauit studio inlustrium hominum aetates et tempora persequendi. Ego uero, inquit Brutus, et delector ista quasi notatione temporum et ad id quod instituisti, oratorum genera distinguere aetatibus, istam diligentiam esse accommodatam puto. (75) Recte, in- teatro no consulado de Caio Cláudio, filho de Ápio Claudio Cego, e Marco Tuditano, exatamente um ano antes do nascimento de Ênio, quinhentos e quatorze anos após a fundação de Roma, conforme afirmação de Ático, que estamos seguindo. De fato, entre os escritores há uma controvérsia acerca da contagem dos anos. Ácio, porém, escreveu que, no quinto consulado de Quinto Máximo, Lívio foi capturado em Tarento, trinta anos depois da data em que teria representado sua peça, de acordo com o que Ático escreve, e com o que nós encontramos nos registros antigos. [73] Segundo Ácio, porém, a peça teria sido representada onze anos depois, no consulado de Caio Cornélio e Quinto Minúcio, durante os jogos em honra à deusa Juventude, que Salinátor havia prometido quando da batalha de Sena. Nesse aspecto, foi tão grande o erro de Ácio que nesse consulado Ênio tinha quarenta anos, como Lívio teria sido contemporâneo, então aquele que primeiro representou uma peça teria sido um pouco mais jovem do que aqueles que haviam representado muitas peças antes do consulado deles, Plauto e Névio.

[74] Se isso não lhe parece muito pertinente à nossa conversa, Bruto, atribua isso a Ático, que me incitou o gosto de pesquisar as gerações e as épocas dos homens ilustres. - Mas, de minha parte, disse Bruto, não só aprecio esta, por assim dizer, notação dos tempos mas também considero esta diligência adequada ao seu propósito de diferenciar os tipos de oradores por épocas. [75] — Você tem razão, 
quam, Brute, intellegis. atque utinam exstarent illa carmina, quae multis saeclis ante suam aetatem in epulis esse cantitata a singulis conuiuis de clarorum uirorum laudibus in Originibus scriptum reliquit Cato. tamen illius, quem in uatibus et Faunis adnumerat Ennius, bellum Punicum quasi Myronis opus delectat. (76) Sit Ennius sane, ut est certe, perfectior: qui si illum, ut simulat, contemneret, non omnia bella persequens primum illud Punicum acerrimum bellum reliquisset. sed ipse dicit cur id faciat. 'scripsere' inquit 'alii rem uorsibus'; et luculente quidem scripserunt, etiam si minus quam tu polite. nec uero tibi aliter uideri debet, qui a Naeuio uel sumpsisti multa, si fateris, uel, si negas, surripuisti. (77) Cum hoc Catone grandiores natu fuerunt C. Flaminius C. Varro Q. Maximus Q. Metellus P. Lentulus P. Crassus, qui cum superiore Africano consul fuit. ipsum Scipionem accepimus non infantem fuisse. filius quidem eius, is qui hunc minorem Scipionem a Paulo adoptauit, si corpore ualuisset, in primis habitus esset disertus; indicant cum oratiunculae tum historia quaedam Graeca scripta dulcissime.

[20] XX. (78) Numeroque eodem fuit Sex. Aelius, iuris quidem ciuilis omnium peritissumus, sed etiam
Bruto, continuei. E oxalá tivessem sobrevivido aqueles cantos, que Catão deixou escrito em suas Origens, que muitas gerações antes de sua época cada um dos convivas, durante os banquetes, entoava em elogio a homens ilustres. No entanto, a Guerra púnica do poeta, que Ênio enumera entre os vates e Faunos, agrada como se fosse uma obra de Míron. [76] Que Ênio seja, como de fato é, o mais completo, se ele desprezasse esse poeta, como finge fazêlo, não teria deixado de lado, ao tratar de todas as guerras, justamente a violentíssima primeira guerra púnica. Mas ele mesmo diz porque o faz. "Outros, diz ele, escreveram versos sobre o tema, e escreveram de modo realmente magnífico, ainda que não tão refinado quanto você. Mas você não deve pensar diferente, você que tomou muita coisa emprestado a Névio, se reconhece a dívida, ou, se não reconhece, roubou muita coisa. [77] Da mesma época de Catão e mais velhos foram Caio Flamínio, Caio Varrão, Quinto Máximo, Quinto Metelo, Públio Lêntulo, Públio Crasso, que foi cônsul com o primeiro Africano. Sabemos que o próprio Cipião não era desarticulado. Mas o seu filho, aquele que adotou de Paulo o jovem Cipião, se tivesse um corpo mais vigoroso, teria sido cosiderado particularmente facundo, não só os breves discursos o indicam como também uma história em grego escrita de modo muito agradável.

[78] E na mesma categoria estava Sexto Élio, certamente o mais perito de todos no direito civil, mas também preparado para 
ad dicendum paratus. de minoribus autem C. Sulpicius Galus, qui maxume omnium nobilium Graecis litteris studuit; isque et oratorum in numero est habitus et fuit reliquis rebus ornatus atque elegans. iam enim erat unctior quaedam splendidiorque consuetudo loquendi. nam hoc praetore ludos Apollini faciente cum Thyesten fabulam docuisset, Q. Marcio Cn. Seruilio consulibus mortem obiit Ennius. (79) Erat isdem temporibus Ti. Gracchus P. f., qui bis consul et censor fuit, cuius est oratio Graeca apud Rhodios; quem ciuem cum grauem tum etiam eloquentem constat fuisse. P. etiam Scipionem Nasicam, qui est Corculum appellatus, qui item bis consul et censor fuit, habitum eloquentem aiunt, illius qui sacra acceperit filium; dicunt etiam L. Lentulum, qui cum C. Figulo consul fuit. Q. Nobiliorem M. f. iam patrio instituto deditum studio litterarum — qui etiam Q. Ennium, qui cum patre eius in Aetolia militauerat, ciuitate donauit, cum triumuir coloniam deduxisset - et T. Annium Luscum huius Q. Fului conlegam non indisertum dicunt fuisse; (80) Atque etiam L. Paullus Africani pater personam principis ciuis facile dicendo tuebatur. et uero etiam tum Catone uiuo, qui annos quinque et octoginta natus excessit e uita, cum quidem eo ipso anno contra Ser. Galbam ad populum summa contentione dixis- a oratória. Já entre os mais jovens, Caio Sulpício Galo, que entre todos os nobres foi o mais versado nas letras gregas, ele que, por um lado, era colocado na classe dos oradores, por outro, era distinto e elegante nos demais assuntos. Com efeito, já havia certo costume de se falar de modo mais polido e mais brilhante. De fato, ele era pretor e celebrava os jogos em honra a Apolo quando Ênio representou a peça Tieste, morrendo no consulado de Quinto Márcio e Gneo Servílio. [79] Na mesma época viveu Tibério Graco, filho de Públio, que foi cônsul duas vezes e censor, de quem há um discurso em grego proferido diante dos rodienses, que foi um cidadão, como se sabe, não apenas severo mas também eloquente. Também se diz que Públio Cipião Nasica, que é chamado de Corculum, que também foi cônsul duas vezes e censor, foi considerado eloquente, filho daquele Cipião que recebeu os rituais sagrados. ${ }^{7}$ Dizem o mesmo de Lúcio Lêntulo, que foi cônsul com Caio Fígulo. Dizem que a Quinto Fúlvio Nobílior, filho de Marco, dedicado ao estudo das letras já pelo ensino paterno que também conferiu cidadania a Quinto Ênio, que havia servido na Etólia com seu pai, quando havia sido triúnviro na fundação da colônia - e a Tito Ânio Lusco, colega deste Quinto Fúlvio, não lhes faltava facúndia. [80] E também Lúcio Paulo, pai do Africano, desempenhava facilmente pela palavra o papel de cidadão mais eminente. E quando Catão ainda era vivo ele que morreu aos oitenta e cinco anos, exatamente no mesmo ano em que discur- 
set, quam etiam orationem scriptam reliquit. [21] XXI. Sed uiuo Catone minores natu multi uno tempore oratores floruerunt.

(81) Nam et A. Albinus, is qui Graece scripsit historiam, qui consul cum L. Lucullo fuit, et litteratus et disertus fuit; et tenuit cum hoc locum quendam etiam Ser. Fuluius et Numerius Fabius Pictor et iuris et litterarum et antiquitatis bene peritus; Quinctusque Fabius Labeo fuit ornatus isdem fere laudibus. nam Q. Metellus, is cuius quattuor filii consulares fuerunt, in primis est habitus eloquens, qui pro L. Cotta dixit accusante Africano; cuius et aliae sunt orationes et contra Ti. Gracchum exposita est in C. Fanni annalibus. (82) Tum ipse L. Cotta est ueterator habitus; sed C. Laelius et $\mathrm{P}$. Africanus in primis eloquentes, quorum exstant orationes, ex quibus existumari de ingeniis oratorum potest. sed inter hos aetate paulum his antecedens sine controuersia Ser. Galba eloquentia praestitit; et nimirum is princeps ex Latinis illa oratorum propria et quasi legituma opera tractauit, ut egrederetur a proposito ornandi causa, ut delectaret animos aut permoueret, ut augeret rem, ut miserationibus, ut communibus locis uteretur. sed nescio quomodo huius, quem constat eloquentia praestitisse, exiliores orationes sunt et redolentes sou diante do povo contra Sérvio Galba com extrema impetuosidade, discurso que também deixou escrito - mas quando Catão era vivo floresceram ao mesmo tempo muitos oradores mais jovens.

[81] Por exemplo, Aulo Albino, aquele que escreveu uma história em grego, que foi cônsul com Lúcio Luculo, foi não só homem de letras mas também facundo; e junto com ele tiveram lugar de certo destaque Sérvio Fúlvio e Sérvio Fábio Pintor, muito versado no direito, nas letras, nas antiguidades; e Quinto Fábio Labeão distinguia-se quase pelos mesmos méritos. Por exemplo, Quinto Metelo, ele que teve quatro filhos consulares, considerado particularmente eloquente, que discursou em defesa de Lúcio Cota, acusado por Africano, de quem não só há alguns discursos mas também um contra Tibério Graco é reproduzido nos anais de Caio Fânio. [82] Nessa época, o próprio Lúcio Cota era considerado bastante experiente, porém entre os mais eloquentes estavam Caio Lélio e Públio Africano, dos quais restam discursos, pelos quais se pode ter uma ideia acerca do engenho dos oradores. Mas entre esses um pouco anterior a eles na idade, sem contestação, sobressaiu-se pela eloquência Sérvio Galba e sem dúvida ele foi o primeiro dos latinos que empregou aquelas operações próprias dos oradores e, por assim dizer, legítimas: que o orador fuja do assunto para ornamentar o discurso, que ele deleite ou incite os ânimos, que ele engrandeça a matéria, que ele se utilize das expressões patéticas, dos lugares comuns. 
magis antiquitatem quam aut Laeli aut Scipionis aut etiam ipsius Catonis; itaque exaruerunt, uix iam ut appareant.

(83) De ipsius Laeli et Scipionis ingenio quamquam ea est fama, ut plurimum tribuatur ambobus, dicendi tamen laus est in Laelio inlustrior. at oratio Laeli de collegiis non melior quam de multis quam uoles Scipionis; non quo illa Laeli quicquam sit dulcius aut quo de religione dici possit augustius, sed multo tamen uetustior et horridior ille quam Scipio; et, cum sint in dicendo uariae uoluntates, delectari mihi magis antiquitate uidetur et lubenter uerbis etiam uti paulo magis priscis Laelius. (84) Sed est mos hominum, ut nolint eundem pluribus rebus excellere. nam ut ex bellica laude aspirare ad Africanum nemo potest, in qua ipsa egregium Viriathi bello reperimus fuisse Laelium: sic ingeni litterarum eloquentiae sapientiae denique etsi utrique primas, priores tamen libenter deferunt Laelio. nec mihi ceterorum iudicio solum uidetur, sed etiam ipsorum inter ipsos concessu ita tributum fuisse.
Mas não sei como os discursos dele, que, como é sabido, se sobressaíam na eloquência, são mais mirrados e tinham mais o aroma da antiguidade do que os de Lélio, de Cipião, ou mesmo do próprio Catão; e tanto se exauriram que já não se veem mais facilmente.

[83] Quanto ao engenho de Lélio e o Cipião, embora haja a fama de que ambos gozaram de alta estima, o mérito oratório, porém, é mais célebre em Lélio. Mas o discurso de Lélio sobre os colégios sacerdotais não é melhor do que qualquer um dos muitos discursos de Cipião, não porque haja algo mais doce do que o discurso de Lélio ou porque sobre a religião fosse possível discursar de modo mais augusto, contudo ele é muito mais antiquado e mais rude do que Cipião; e, como são diversas as disposições para a oratória, parece-me que a Lélio agrada mais a maneira antiquada e que deliberadamente também se utilizava de palavras mais arcaicas. [84] Mas é um costume humano não querer reconhecer que a mesma pessoa alcance a excelência em muitos campos de atuação. De fato, se ninguém pode se aproximar de Africano na glória bélica, embora saibamos que Lélio compartilhou dela de modo notável na guerra contra Viriato, assim também quanto ao engenho, ao cultivo das letras, à eloquência, à sabedoria, enfim, embora ambos estivessem no primeiro plano, de bom grado davam o primado a Lélio. E me parece que isso era concedido não só pela opinião das outras pessoas mas também por eles próprios em consentimento 
(85) Erat omnino tum mos, ut in reliquis rebus melior, sic in hoc ipso humanior, ut faciles essent in suum cuique tribuendo. [22] XXII. memoria teneo Smyrnae me ex P. Rutilio Rufo audisse, cum diceret adulescentulo se accidisse, ut ex senatus consulto P. Scipio et D. Brutus, ut opinor, consules de re atroci magnaque quaererent. nam cum in silua Sila facta caedes esset notique homines interfecti insimulareturque familia, partim etiam liberi societatis eius, quae picarias de P. Cornelio L. Mummio censoribus redemisset, decreuisse senatum, ut de ea re cognoscerent et statuerent consules. (86) Causam pro publicanis accurate, ut semper solitus esset, eleganterque dixisse Laelium. cum consules re audita 'amplius' de consili sententia pronuntiauissent, paucis interpositis diebus iterum Laelium multo diligentius meliusque dixisse iterumque eodem modo a consulibus rem esse prolatam. tum Laelium, cum eum socii domum reduxissent egissentque gratias et ne defatigaretur orauissent, locutum esse ita: se, quae fecisset, honoris eorum causa studiose accurateque fecisse, sed se arbitrari causam illam a Ser. Galba, quod is in dicendo ardentior acriorque esset, grauius et uehementius posse defendi. itaque auctoritate C. Laeli publicanos causam detulisse ad Galbam; (87) Illum mútuo.

[85] De modo geral, havia naquela época o costume, melhor nos demais aspectos e mais humano neste caso, de dar prontamente a cada um o que lhe era devido. Eu me recordo que ouvi de Públio Rutílio Rufo em Esmirna, quando relatava o que lhe havia acontecido em sua juventude, que por decreto do senado os cônsules Públio Cipião e Décimo Bruto, creio eu, deviam mover um processo sobre um crime terrível e grave. Pois bem, na floresta Sila havia ocorrido um massacre, e homens importantes foram mortos, sendo acusados os escravos e também alguns homens livres de uma sociedade, que havia adquirido dos censores Públio Cornélio e Lúcio Múmio o direito de extração da pez, o senado decretou que os cônsules se informassem e julgassem esse caso. [86] Lélio discursou em defesa dos publicanos com o rigor e a elegância costumeiros de sempre. Quando os cônsules, depois de ouvirem a defesa, decretaram, segundo parecer do conselho, a necessidade de mais explicações, poucos dias depois Lélio discursou novamente melhor e com muito mais diligência, mais uma vez e do mesmo modo os cônsules decidiram que o caso fosse prorrogado. Então, quando os sócios acompanharam Lélio até sua casa, agradeceram-lhe e pediram que ele não se deixasse desencorajar, ele falou o seguinte: aquilo que havia feito, ele havia feito com empenho e rigor em nome da honra deles, mas acreditava que aquela causa poderia ser defendida de modo mais severo e veemente por Sérvio Galba, pois 
autem, quod ei uiro succedendum esset, uerecunde et dubitanter recepisse. unum quasi comperendinatus medium diem fuisse, quem totum Galbam in consideranda causa componendaque posuisse; et cum cognitionis dies esset et ipse Rutilius rogatu sociorum domum ad Galbam mane uenisset, ut eum admoneret et ad dicendi tempus adduceret, usque illum, quoad ei nuntiatum esset consules descendisse, omnibus exclusis commentatum in quadam testudine cum seruis litteratis fuisse, quorum alii aliud dictare eodem (a) tempore solitus esset. interim cum esset ei nuntiatum tempus esse, exisse in aedes eo colore et iis oculis, ut egisse causam, non commentatum putares.

(88) Addebat etiam, idque ad rem pertinere putabat, scriptores illos male mulcatos exisse cum Galba; ex quo significabat illum non in agendo solum, sed etiam in meditando uehementem atque incensum fuisse. quid multa? magna exspectatione, plurumis audientibus, coram ipso Laelio sic illam causam tanta ui tantaque grauitate dixisse Galbam, ut nulla fere pars orationis silentio praeteriretur. itaque multis querelis multaque miseratione adhibita socios omnibus ele era mais inflamado e mais enérgico ao discursar. Por essa razão, diante da recomendação de Caio Lélio, os publicanos confiaram a causa a Galba. [87] Mas ele, por ter de suceder esse homem, aceitou-a com cautela e hesitação. Houve um único dia durante essa espécie de prorrogação do processo que Galba reservou-o inteiramente para o exame e preparação da causa, e, quando chegou o dia do processo, o próprio Rutílio, a pedido dos sócios, foi até a casa de Galba pela manhã, para aconselhálo e acompanhá-lo na hora de discursar, ele, até o momento em que lhe foi anunciado que os cônsules haviam descido para o fórum, num aposento completamente isolado da casa, continuava a se preparar com seus escravos literatos, aos quais costumava ditar muitas coisas ao mesmo tempo. Nesse intervalo, quando lhe foi anunciado que havia chegado a hora, voltou para casa com tanta tensão na face e nos olhos que se poderia pensar que já tivesse pronunciado o discurso, não que o tivesse preparado.

[88] Rutílio acrescentava também algo que ele achava relevante, que os escribas saíam com Glaba muito maltratados, com isso queria dizer que ele era veemente e inflamado não só ao proferir um discurso, mas também ao prepará-lo. Por que me alongar? Sob grande expectativa, numerosa audiência, na presença do próprio Lélio, Galba defendeu aquela causa com tanto vigor e tanta severidade que quase nenhuma parte de seu discurso passou em silêncio. Por isso, depois de muitas expressões lastimosas e de muito recorrer ao 
adprobantibus illa die quaestione liberatos esse.

[23] XXIII. (89) Ex hac Rutili narratione suspicari licet, cum duae summae sint in oratore laudes, una subtiliter disputandi ad docendum, altera grauiter agendi ad animos audientium permouendos, multoque plus proficiat is qui inflammet iudicem quam ille qui doceat, elegantiam in Laelio, uim in Galba fuisse. quae quidem uis tum maxume cognitast, cum Lusitanis a Ser- Galba praetore contra interpositam, ut existumabatur, fidem interfectis L. Libone tribuno plebis populum incitante et rogationem in Galbam priuilegi similem ferente, summa senectute, ut ante dixi, M. Cato legem suadens in Galbam multa dixit; quam orationem in Origines suas rettulit, paucis ante quam mortuus est (an) diebus an mensibus. (90) Tum igitur nihil recusans Galba pro sese et populi Romani fidem implorans cum suos pueros tum C. Gali etiam filium flens commendabat, cuius orbitas et fletus mire miserabilis fuit propter recentem memoriam clarissimi patris; isque se tum eripuit flamma, propter pueros misericordia populi commota, sicut idem scriptum reliquit Cato. atque etiam ipsum Libonem non infantem uideo fuisse, ut ex orationibus eius intellegi potest. (91) Cum haec dixissem et paulum in- patético, os sócios foram naquele dia absolvidos daquela acusação pelo assentimento geral.

[89] Dessa narração de Rutílio, é possível deduzir que: como são duas as principais qualidades do orador, a primeira, expor minuciosamente o que se deve instruir, a segunda, atuar com veemência para comover os ânimos dos ouvintes, e obtém muito mais êxito aquele que inflama o juiz do que aquele que instrui, havia elegância em Lélio, vigor em Galba. Esse vigor, ademais, ficou conhecido sobretudo quando Sérvio Galba era pretor e foi acusado, como se pensava, de quebra da palavra empenhada no massacre dos lusitanos, Lúcio Libão era tribuno da plebe e incitava o povo e apresentou uma proposta de lei pessoal contra Galba, Marco Catão já bastante idoso, como disse antes, discursou longamente contra Galba. Ele reportou esse discurso nas suas Origens, poucos dias ou meses antes de morrer. [90] Na ocasião, então, Galba, não reclamando nada para si, implorando a proteção do povo romano, chorando confiava a guarda tanto de seus filhos como do filho de Caio Galo, a orfandade e suas lágrimas suscitaram extraordinária comiseração por causa da lembrança recente de seu ilustríssimo pai. E Galba, nesse dia, se livrou da ruína, por causa da compaixão suscitada no povo pelas crianças, conforme Catão deixou escrito. E também vejo que o próprio Libão não era desarticulado, como se pode depreender de seus discursos. [91] Depois que eu disse isso e fiz uma pequena pausa, Bruto 
terquieuissem: quid igitur, inquit, est causae, Brutus, si tanta uirtus in oratore Galba fuit, cur ea nulla in orationibus eius appareat? quod mirari non possum in eis, qui nihil omnino scripti reliquerunt.

[24] XXIV. Nec enim est eadem inquam, Brute, causa non scribendi et non tam bene scribendi quam dixerint. nam uidemus alios oratores inertia nihil scripsisse, ne domesticus etiam labor accederet ad forensem - pleraeque enim scribuntur orationes habitae iam, non ut habeantur _ ; (92) Alios non laborare ut meliores fiant — nulla enim res tantum ad dicendum proficit quantum scriptio: memoriam autem in posterum ingeni sui non desiderant, cum se putant satis magnam adeptos esse dicendi gloriam eamque etiam maiorem uisum iri, si in existimantium arbitrium sua scripta non uenerint ; alios, quod melius putent dicere se posse quam scribere, quod peringeniosis hominibus neque satis doctis plerumque contingit, ut ipsi Galbae. (93) Quem fortasse uis non ingeni solum sed etiam animi et naturalis quidam dolor dicentem incendebat efficiebatque ut et incitata et grauis et uehemens esset oratio; dein cum otiosus stilum prehenderat motusque omnis animi tamquam uentus hominem defecerat, flaccescebat oratio. quod iis qui limatius dicendi consectantur genus accidere non so- perguntou: - Por qual motivo, então, se havia tanto valor em Galba como orador, nada disso aparece em seus discursos? Não posso me surpreender com isso no caso daqueles que não deixaram absolutamente nada escrito.

— É verdade: não é pela mesma razão, Bruto, respondi, que se dá o não escrever e o não escrever tão bem quanto se discursa. De fato, vemos que alguns oradores não escreveram por preguiça, para não se acrescentar um trabalho doméstico ao forense - é que a maior parte dos discursos é escrita depois de pronunciados, não para serem pronunciados —, [92] outros não se empenham em se tornarem melhores - é que nenhuma outra coisa auxilia tanto a oratória quanto a escrita; por outro lado, não têm o desejo de legar à posteridade a memória de seu engenho, considerando que já alcançaram uma glória oratória grande o suficiente e que ela parecerá ainda maior se seus escritos não chegarem ao julgamento dos críticos; outros, por considerarem que são mais capazes de discursar do que de escrever, o que acontece geralmente aos homens muito engenhosos que não são cultos o bastante, como o próprio Galba. [93] Quando ele discursava talvez não só a força do engenho mas também do ânimo e uma comoção natural o inflamavam e faziam com que o discursso fosse impetuoso, severo, veemente; depois, quando tranquilo pegava o estilo ${ }^{8}$ e toda emoção como um vento o abandonava, o discurso se enfraquecia. Isso não costuma acontecer àqueles que têm em mira um gênero oratório mais 
let, propterea quod prudentia numquam deficit oratorem, qua ille utens eodem modo possit et dicere et scribere; ardor animi non semper adest, isque cum consedit, omnis illa uis et quasi flamma oratoris exstinguitur. (94) Hanc igitur ob causam uidetur Laeli mens spirare etiam in scriptis, Galbae autem uis occidisse.

[25] XXV. Fuerunt etiam in oratorum numero mediocrium L. et Sp. Mummii fratres, quorum exstant amborum orationes; simplex quidem Lucius et antiquus, Spurius autem nihilo ille quidem ornatior, sed tamen astrictior; fuit enim doctus e disciplina Stoicorum. multae sunt Sp- Albini orationes. sunt etiam L. et C. Aureliorum Orestarum, quos aliquo uideo in numero oratorum fuisse. (95) P. etiam Popillius cum ciuis egregius tum non indisertus fuit; Gaius uero filius eius disertus, Gaiusque Tuditanus cum omni uita atque uictu excultus atque expolitus, tum eius elegans est habitum etiam orationis genus. eodemque in genere est habitus is, qui iniuria accepta fregit Ti. Gracchum patientia, ciuis in rebus optimis constantissimus M. Octauius. at uero M. Aemilius Lepidus, qui est Porcina dictus, isdem temporibus fere quibus Galba, sed paulo minor natu et summus orator est habitus et fuit, apparet ex ora- elaborado, pelo fato de que a prudência nunca abandona o orador, recorrendo a ela ele é capaz tanto de discursar como de escrever do mesmo modo, o ardor do ânimo nem sempre está presente, e, quando ele se acalma, toda aquela força e, por assim dizer, chama do orador se extingue. [94] É por isso, então, que a mente de Lélio parece continuar viva mesmo em seus escritos, enquanto a força de Galba parece ter morrido.

Também estavam na categoria dos oradores medianos os irmãos Lúcio e Espúrio Múmio, de ambos os quais restam discursos; Lúcio, certamente, era simples e antiquado, Espúrio, embora nem um pouco ornado, era, contudo, mais cerrado; é que ele foi instruído na doutrina dos estoicos. Há muitos discursos de Espúrio Albino. Há também de Lúcio e Caio Aurélio Oreste, que, a meu ver, gozavam de certa estima entre os oradores. [95] Também Públio Polpílio foi a um só tempo cidadão insigne e não desarticulado; seu filho Caio, em contrapartida, era bem articulado. Caio Tuditano, por um lado, foi cultivado e polido em toda sua vida social e privada, por outro lado, o seu gênero oratório também era considerado elegante. E na mesma categoria estava aquele que, depois de sofrer um agravo arruinou Tibério Graco com sua oposição, cidadão muito constante em seus ótimos princípios, Marco Otávio. Mas Marco Emílio Lépido, dito Porcina, quase da mesma geração de Galba, porém um pouco mais jovem, não apenas foi considerado excelente orador, mas, como fica 
tionibus, scriptor sane bonus. (96) Ut hoc in oratore Latino primum mihi uidetur et leuitas apparuisse illa Graecorum et uerborum comprensio et iam artifex, ut ita dicam, stilus. hunc studiose duo adulescentes ingeniosissimi et prope aequales C. Carbo et Ti. Gracchus audire soliti sunt; de quibus iam dicendi locus erit, cum de senioribus pauca dixero. Q. enim Pompeius non contemptus orator temporibus illis fuit, qui summos honores homo per se cognitus sine ulla commendatione maiorum est adeptus.

(97) Tum L. Cassius multum potuit non eloquentia, sed dicendo tamen; homo non liberalitate, ut alii, sed ipsa tristitia et seueritate popularis, cuius quidem legi tabellariae M. Antius Briso tribunus plebis diu restitit M. Lepido consule adiuuante; eaque res P. Africano uituperationi fuit, quod eius auctoritate de sententia deductus Briso putabatur. tum duo Caepiones multum clientes consilio et lingua, plus auctoritate tamen et gratia subleuabant. Sex. Pompei sunt scripta nec nimis extenuata, quamquam ueterum est similis, et plena prudentiae. [26] XXVI. (98) P. Crassum ualde probatum oratorem isdem fere temporibus accepimus, qui et ingenio ualuit et studio manifesto em seus discursos, foi realmente um bom escritor. [96] Nesse orador latino, me parece que se manifestou pela primeira vez não só o famoso refinamento dos gregos mas também a construção periódica, bem como já havia a escrita, por assim dizer, feita com arte. Dois jovens muitíssimo engenhosos e quase contemporâneos, Caio Carbão e Tibério Graco, costumavam ouvi-lo com assiduidade, sobre os quais logo será o momento de falar, depois de eu falar um pouco sobre os mais velhos. De fato, Quinto Pompeu foi um orador nada desprezível para aquela época, ele, um homem notável por seus próprios méritos, que alcançou as mais elevadas honras sem nenhum precedente entre seus antepassados.

[97] Nessa época, Lúcio Cássio exercia grande influência não pela sua eloquência, mas pela sua palavra, homem popular não por sua liberalidade, como outros, mas por sua austeridade e severidade. Contra sua lei tabelária se opôs por muito tempo o tribuno Marco Âncio Brisão, secundado pelo cônsul Marco Lépido. E esse caso foi motivo de vitupério para Públio Africano, pois se pensava que por sua influência Brisão fora induzido a mudar de parecer. $\mathrm{Na}$ mesma época, os dois Cipiões auxiliavam muito seus clientes com o discernimento e com a palavra, embora ainda mais com a autoridade e com a influência. E existem escritos de Sexto Pompeu e não demasiado tênues, embora semelhantes aos antigos e cheios de prudência. [98] Sabemos que Públio Crasso, quase na mesma 
et habuit quasdam etiam domesticas disciplinas. nam et cum summo illo oratore Ser. Galba, cuius Gaio filio filiam suam conlocauerat, adfinitate sese deuinxerat et cum esset P. Muci filius fratremque haberet P. Scaeuolam, domi ius ciuile cognouerat. in eo industriam constat summam fuisse maxumamque gratiam, cum et consuleretur plurimum et diceret. (99) Horum aetatibus adiuncti duo C. Fannii C. M. filii fuerunt; quorum Gai filius, qui consul cum Domitio fuit, unam orationem de sociis et nomine Latino contra Gracchum reliquit sane et bonam et nobilem. Tum Atticus: quid ergo? estne ista Fanni? nam uaria opinio pueris nobis erat. alii a C. Persio litterato homine scriptam esse aiebant, illo quem significat ualde doctum esse Lucilius; alii multos nobilis, quod quisque potuisset, in illam orationem contulisse.

(100) Tum ego: audiui equidem ista, inquam, de maioribus natu, sed nunquam sum adductus ut crederem; eamque suspicionem propter hanc causam credo fuisse, quod Fannius in mediocribus oratoribus habitus esset, oratio autem uel optuma esset illo quidem tempore orationum om- época, era um orador muito estimado, que se distinguia, seja pelo engenho, seja pelo estudo, seja porque em sua casa também foi instruído em certas doutrinas. Com efeito, por um lado, ele tinha uma estreita ligação de parentesco com o excelente orador Sérvio Galba, a cujo filho Caio concedera sua filha em casamento, por outro lado, com era filho de Públio Múcio e tinha Públio Cévola como irmão, aprendera em casa o direito civil. Como se sabe, ele era de uma diligência extraordinária e exercia uma enorme influência, tanto nas inúmeras vezes em que era consultado, como quando discursava. [99] Pertenceram a esse período os dois Caio Fânio, filhos de Caio e Mário, um dos quais, o filho de Caio, que foi cônsul com Domítio, deixou um único discurso sobre os aliados e o nome latino contra Graco, muito bom e bem conhecido. Ático, então, perguntou: - Mas como? Este discurso é de Fânio? As opiniões eram variadas em nossa juventude. Alguns diziam que havia sido escrito por Caio Pérsio, homem de letras, aquele a quem Lucílio se refere como sendo muito erudito; outros afirmam que muitos nobres, conforme as possiblidades de cada um, colaboraram naquele discurso.

[100] Eu, então, respondi, — De minha parte ouvi isso dos mais velhos, mas nunca consegui acreditar, e creio que essa desconfiança se deva ao fato de que Fânio era considerado um orador mediano, mas aquele discurso era o melhor de todos os discursos, ao menos naquela época. Mas não é o tipo de discurso que pareça 
nium. sed nec eiusmodi est, ut a pluribus confusa uideatur - unus enim sonus est totius orationis et idem stilus - , nec de Persio reticuisset Gracchus, cum ei Fannius de Menelao Maratheno et de ceteris obiecisset; praesertim cum Fannius numquam sit habitus elinguis. nam et causas defensitauit et tribunatus eius arbitrio et auctoritate P. Africani gestus non obscurus fuit. (101) Alter autem C. Fannius M. filius, C. Laeli gener, et moribus et ipso genere dicendi durior. is soceri instituto, quem, quia cooptatus in augurum conlegium non erat, non admodum diligebat, praesertim cum ille Q. Scaeuolam sibi minorem natu generum praetulisset - cui tamen Laelius se excusans non genero minori dixit se illud, sed maiori filiae detulisse - , is tamen instituto Laeli Panaetium audiuerat. eius omnis in dicendo facultas historia ipsius non ineleganter scripta perspici potest, quae neque nimis est infans neque perfecte diserta. (102) Mucius autem augur quod pro se opus erat ipse dicebat, ut de pecuniis repetundis contra $\mathrm{T}$ - Albucium. is oratorum in numero non fuit, iuris ciuilis intellegentia atque omni prudentiae genere praestitit. L. Coelius Antipater scriptor, quemadmodum uidetis, fuit ut temporibus illis luculentus, iuris ualde peritus, multorum etiam, ut L. Crassi, magister. uma mescla de vários oradores - o tom de todo o discurso é uno e também o estilo -, nem Graco teria passado em silêncio sobre Pérsio, quando Fânio o repreendia pela ajuda de Menelao de Máratos e de outros; sobretudo porque Fânio nunca foi considerado infacundo. E não só costumava defender causas mas também seu tribunado, sob o poder e a autoridade de Públio Africano, não transcorreu na obscuridade. [101] Já o outro Caio Fânio, filho de Marco, genro de Caio Lélio, era mais duro tanto no caráter como pela própria maneira de discursar. Ele, à maneira do sogro, a quem não estimava muito, por não ter sido cooptado para o colégio dos áugures, sobretudo porque ele havia preferido o genro mais jovem Quinto Cévola - embora Lélio desculpando-se lhe tenha dito que não concedia isso ao genro mais jovem, mas a filha mais velha -, ele, no entanto, à maneira de Lélio, tinha ouvido os ensinamentos de Panécio. Toda sua aptidão para discursar pode ser depreendida de sua obra histórica, escrita de modo não deselegante, que não é demasiado desarticulada e não é perfeitamente expressiva. [102] Quanto a Múcio, o augure, discursava em sua própria defesa quando era necessário, como contra Tito Albúcio no processo por concussão. Ele não estava na categoria dos oradores, sobressaia-se pelo conhecimento do direito civil e por todo tipo de inteligência prática. O escritor Lúcio Célio Antípatro foi, como vocês podem ver, notável para aquela época, muito conhecedor do direito, também foi mestre de muitos, 
[27] XXVII. (103) Utinam in Ti. Graccho Gaioque Carbone talis mens ad rem publicam bene gerendam fuisset quale ingenium ad bene dicendum fuit: profecto nemo his uiris gloria praestitisset. sed eorum alter propter turbulentissumum tribunatum, ad quem ex inuidia foederis Numantini bonis iratus accesserat, ab ipsa re publica est interfectus; alter propter perpetuam in populari ratione leuitatem morte uoluntaria se a seueritate iudicum uindicauit. sed fuit uterque summus orator. (104) Atque hoc memoria patrum teste dicimus. nam et Carbonis et Gracchi habemus orationes nondum satis splendidas uerbis, sed acutas prudentiaeque plenissumas. fuit Gracchus diligentia Corneliae matris a puero doctus et Graecis litteris eruditus. nam semper habuit exquisitos e Graecia magistros, in eis iam adulescens Diophanem Mytilenaeum Graeciae temporibus illis disertissumum. sed ei breue tempus ingeni augendi et declarandi fuit. (105) Carbo, quoi uita suppeditauit, est in multis iudiciis causisque cognitus. hunc qui audierant prudentes homines, in quibus familiaris noster L. Gellius qui se illi contubernalem in consulatu fuisse narrabat, canorum oratorem et uolubilem et satis acrem atque eundem et uehementem et ualde dulcem et perfacetum fuisse como de Lúcio Crasso.

[103] Oxalá tivesse havido em Tibério Graco e Caio Carbão uma disposição para o bom governo da república tal como havia o talento para discursar bem. Sem dúvida, ninguém teria superado a glória desses homens. Porém, o primeiro deles, por causa de seu turbulentíssimo tribunado, que assumira já sofrendo a ira dos bons cidadãos pela impopularidade do tratado de $\mathrm{Nu}$ mância, foi morto pela própria república; o segundo, por sua contínua leviandade em sua conduta popular, se livrou da severidade dos juízes com uma morte voluntária. Mas ambos foram oradores excelentes. [104] E digo isso tomando por testemunha a memória de nossos pais: temos discursos tanto de Carbão quanto de Graco, ainda não brilhantes o bastante no que concerne às palavras, mas penetrantes e plenos de sabedoria. Graco foi instruído desde menino por diligência de sua mãe Cornélia e cultivado nas letras gregas. De fato, contou sempre com os mais refinados mestres da Grécia, entre eles, ainda na juventude, Diófanes de Mitilene, o mais expressivo da Grécia naquela época. Mas ele teve pouco tempo para aumentar e mostrar seu engenho. [105] Carbão, para quem a vida foi mais generosa, se tornou conhecido em muitos processos e litígios. Os homens prudentes que o ouviram, entre eles o nosso amigo Lúcio Gélio, que relatava ter estado em companhia dele em seu consulado, diziam que havia sido orador melodioso e fluente e bastante impetuoso e, ao mesmo tempo, não só veemente e muito agradá- 
dicebat; addebat industrium etiam et diligentem et in exercitationibus commentationibusque multum operae solitum esse ponere. (106) Hic optimus illis temporibus est patronus habitus eoque forum tenente plura fieri iudicia coeperunt. nam et quaestiones perpetuae hoc adulescente constitutae sunt, quae antea nullae fuerunt; L- enim Piso tribunus plebis legem primus de pecuniis repetundis Censorino et Manilio consulibus tulit - ipse etiam Piso et causas egit et multarum legum aut auctor aut dissuasor fuit, isque et orationes reliquit, quae iam euanuerunt, et annales sane exiliter scriptos - ; et iudicia populi, quibus aderat Carbo, iam magis patronum desiderabant tabella data; quam legem L. Cassius Lepido et Mancino consulibus tulit.

[28] XXVIII. (107) Vester etiam D. Brutus M. filius, ut ex familiari eius L. Accio poeta sum audire solitus, et dicere non inculte solebat et erat cum litteris Latinis tum etiam Graecis, ut temporibus illis, eruditus. quae tribuebat idem Accius etiam Q. Maxumo L. Pauli nepoti; et uero ante Maxumum illum Scipionem, quo duce priuato Ti. Gracchus occisus esset, cum omnibus in rebus uehementem tum acrem aiebat in dicendo fuisse. (108) Tum etiam P. Lentulus ille princeps ad rem publicam dumtaxat quod opus vel mas também muito espirituoso. Gélio acrescentava que ele também era zeloso e diligente e que costumava se dedicar muito aos exercícios e à preparação de discursos. [106] Ele foi considerado, naquela época, o melhor patrono, e quando ele dominava o fórum os processos judiciários começaram a se tornar mais numerosos, pois foram instituídos em sua juventude os tribunais permanentes, que não existiam antes. De fato, o tribuno da plebe Lúcio Pisão, no consulado de Censorino e Manílio, foi o primeiro a propor uma lei sobre concussão - o próprio Pisão também defendeu causas, foi autor ou dissuasor de muitas leis; e ele deixou não só discursos, que já se perderam, mas também anais escritos de modo realmente árido -; e os tribunais do povo, nos quais Carbão tomava parte, já requisitavam mais do patrono por causa do voto secreto, essa lei foi proposta por Lúcio Cássio no consulado de Lépido e Mancino.

[107] Também o seu Décimo Bruto, filho de Marco, conforme eu costumava ouvir do amigo dele, o poeta Lúcio Ácio, não só costumava discursar de modo não inculto, mas também era cultivado tanto nas letras latinas como nas gregas, ao menos para aquela época. As mesmas qualidades Ácio atribuía também a Quinto Máximo, neto de Lúcio Paulo; e dizia que, antes de Máximo, aquele Cipião, que comandou a ação privada em que Tibério Graco foi morto, havia sido veemente em todos os assuntos e enérgico no discurso. [108] Também se diz que o famoso Públio Lêntulo, o primeiro senador, pelo menos naquilo que 
esset satis habuisse eloquentiae dicitur; isdemque temporibus L. Furius Philus perbene Latine loqui putabatur litteratiusque quam ceteri; $P$. Scaeuola ualde prudenter et acute; paulo etiam copiosius nec multo minus prudenter M. Manilius. Appi Claudi uolubilis sed paulo feruidior oratio. erat in aliquo numero etiam M. Fuluius Flaccus et C. Cato Africani sororis filius, mediocres oratores; etsi Flacci scripta sunt, sed ut studiosi litterarum. Flacci autem aemulus P- Decius fuit, non infans ille quidem sed ut uita sic oratione etiam turbulentus. (109) M. Drusus C. f., qui in tribunatu C. Gracchum conlegam iterum tribunum fregit, uir et oratione grauis et auctoritate, eique proxime adiunctus C. Drusus frater fuit. tuus etiam gentilis, Brute, M. Pennus facete agitauit in tribunatu C. Gracchum paulum aetate antecedens. fuit enim M. Lepido et L. Oreste consulibus quaestor Gracchus, tribunus Pennus illius Marci filius, qui cum Q. Aelio consul fuit; sed is omnia summa sperans aedilicius est mortuus. nam de T. Flaminino, quem ipse uidi, nihil accepi nisi Latine diligenter locutum. era necessário para a disputa política, possuía uma eloquência suficiente; e na mesma época estimava-se que Lúcio Furo Filo falava um excelente latim e era mais letrado do que os demais, que Públio Cévola falava com muita prudência e perspicácia; além disso, Mânio Manílio era um pouco mais copioso e não muito menos prudente. $\mathrm{O}$ discurso de Ápio Cláudio era fluente mas um pouco mais impetuoso. Também gozavam de certa consideração Marco Fúlvio Flaco e Caio Catão, filho da irmã do Africano, oradores modestos. Existem escritos de Flaco, mas são de um estudioso das letras. E foi êmulo de Flaco Públio Décio, ele não era desarticulado, é verdade, mas tal como sua vida, o seu discurso era também turbulento. [109] Marco Druso, filho de Caio, que em seu tribunado abateu seu colega Caio Graco, tribuno pela segunda vez, era um homem grandioso tanto por sua capacidade oratória como por sua autoridade, e muito perto dele estava seu irmão Caio Druso. E também um familiar seu, Bruto, Marco Peno, em seu tribunado atacou com espirituosidade Caio Graco, um pouco mais velho do que ele. De fato, no consulado de Marco Lépido e Lúcio Orestes, Graco foi questor, o tribuno era Peno, filho daquele Marco, que foi cônsul com Quinto Élio; mas ele, que tinha esperanças de alcançar as mais elevadas honras, morreu edil. De Tito Flaminino, pois, que eu vi pessoalmente, ouvi dizer apenas que falava um latim esmerado. 
[29] XXIX. (110) His adiuncti sunt C. Curio M. Scaurus P. Rutilius C. Gracchus. de Scauro et Rutilio breuiter licet dicere, quorum neuter summi oratoris habuit laudem et est uterque in multis causis uersatus. erat in quibusdam laudandis uiris, etiam si maximi ingeni non essent, probabilis tamen industria; quamquam his quidem non omnino ingenium, sed oratorium ingenium defuit. neque enim refert uidere quid dicendum sit, nisi id queas solute et suauiter dicere; ne id quidem satis est, nisi id quod dicitur fit uoce uoltu motuque conditius. (111) Quid dicam opus esse doctrina? sine qua etiam si quid bene dicitur adiuuante natura, tamen id, quia fortuito fit, semper paratum esse non potest. in Scauri oratione, sapientis hominis et recti, grauitas summa et naturalis quaedam inerat auctoritas, non ut causam sed ut testimonium dicere putares, cum pro reo diceret. (112) Hoc dicendi genus ad patrocinia mediocriter aptum uidebatur, ad senatoriam uero sententiam, cuius erat ille princeps, uel maxume; significabat enim non prudentiam solum, sed, quod maxume rem continebat, fidem. habebat hoc a natura ipsa, quod a doctrina non facile posset; quamquam huius quoque ipsius rei, quemadmodum scis, praecepta sunt. huius et orationes sunt et tres ad L. Fufidium libri scripti de uita ip-
[110] Junto a eles estavam Caio $\mathrm{Cu}-$ rião, Marco Escauro, Públio Rutílio, Caio Graco. Sobre Escauro e Rutílio podemos falar brevemente: nenhum deles teve a fama de grande orador, e ambos se envolveram em muitas causas. Alguns homens merecedores de louvor, embora não tivessem um engenho dos maiores, mostravam uma diligência digna de aprovação; no entanto, não lhes faltava, é verdade, o engenho de maneira geral, mas o engenho oratório. E, de fato, não importa saber o que se deve dizer, se não se for capaz de dizê-lo de maneira fluente e agradável; nem mesmo isso é suficiente, se o que é dito não ficar mais saboroso por causa da voz, do semblante e do gesto. [111] Que devo dizer sobre a necessidade do conhecimento teórico? Sem o qual, ainda que se possa discursar bem com o auxílio da aptidão natural, todavia, porque ocorre fortuitamente, isso nem sempre pode estar acessível. No discurso de Escauro, homem sábio e justo, havia extrema gravidade e uma autoridade natural, quando discursava em prol de um réu, podia se pensar não que defendia uma causa mas que prestava um testemunho. [112] Este gênero oratório parecia medianamente apto para atuar como patrono, mas muito conveniente para expressar seu parecer no senado, que ele era o primeiro a fazê-lo; de fato, denotava não só sua prudência, mas, o que era mais importante, sua credibilidade. Possuía isso por sua própria natureza, o que não conseguiria facilmente com o conhecimento teórico, embora também haja preceitos sobre esta matéria 
sius acta sane utiles, quos nemo legit; at Cyri uitam et disciplinam legunt, praeclaram illam quidem, sed neque tam nostris rebus aptam nec tamen Scauri laudibus anteponendam.

(113) Ipse etiam Fufidius in aliquo patronorum numero fuit. [30] XXX. Rutilius autem in quodam tristi et seuero genere dicendi uersatus est. erat uterque natura uehemens et acer; itaque cum una consulatum petiuissent, non ille solum, qui repulsam tulerat, accusauit ambitus designatum competitorem, sed Scaurus etiam absolutus Rutilium in iudicium uocauit. multaque opera multaque industria Rutilius fuit, quae erat propterea gratior, quod idem magnum munus de iure respondendi sustinebat. (114) Sunt eius orationes ieiunae; multa praeclara de iure; doctus uir et Graecis litteris eruditus, Panaeti auditor, prope perfectus in Stoicis; quorum peracutum et artis plenum orationis genus scis tamen esse exile nec satis populari adsensioni adcommodatum. itaque illa, quae propria est huius disciplinae, philosophorum de se ipsorum opinio firma in hoc uiro et stabilis inuenta est. (115) Qui quom innocentissumus in iudicium uocatus esset, quo iudicio conuolsam penitus específica, como você sabe. Dele restam discursos, uma autobiografia escrita em três livros bastante úteis dedicados a Lúcio Fufídio, que ninguém lê, mas leem a vida e educação de Ciro, obra realmente ilustre, embora não seja tão apropriada à nossa realidade nem deva ser anteposta ao elogio que Escauro fez dos próprios méritos.

[113] O próprio Fufídio também gozou de alguma consideração entre os patronos. Rutílio, por sua vez, cultivou um gênero oratório um tanto austero e severo. Ambos tinham a natureza veemente e enérgica. $\mathrm{E}$ assim, quando concorreram juntos ao consulado, não só aquele que fora derrotado acusou de fraude seu adversário, designado cônsul, mas também Escauro, depois de absolvido, citou Rutílio em juízo. E havia muito empenho e muito zelo em Rutílio, que eram mais apreciáveis ainda pelo fato de que também desempenhava a importante função de jurisconsulto. [114] Seus discursos são áridos, há muita coisa esplêndida sobre o direito, trata-se de um homem erudito e cultivado nas letras gregas, discípulo de Panécio, quase completo na doutrina dos estóicos. O gênero oratório deles é muito agudo e repleto de técnica, você sabe; no entanto, é exíguo e não muito apropriado para a adesão popular. Portanto, aquela opinião dos filósofos acerca de si mesmos, que é típica dessa doutrina, se manifestou nesse homem de modo firme e constante. [115] Ele, malgrado sua plena inocência, havia sido levado a juízo, num julgamento que, como sabemos, aba- 
scimus esse rem publicam, cum essent eo tempore eloquentissimi uiri L. Crassus et M. Antonius consulares, eorum adhibere neutrum uoluit. dixit ipse pro sese et pauca C. Cotta, quod sororis erat filius - et is quidem tamen ut orator, quamquam erat admodum adulescens - , et Q. Mucius enucleate ille quidem et polite, ut solebat, nequaquam autem ea ui atque copia, quam genus illud iudici et magnitudo causae postulabat. (116) Habemus igitur in Stoicis oratoribus Rutilium, Scaurum in antiquis; utrumque tamen laudemus, quoniam per illos ne haec quidem in ciuitate genera hac oratoria laude caruerunt. uolo enim ut in scaena sic etiam in foro non eos modo laudari, qui celeri motu et difficili utantur, sed eos etiam, quos statarios appellant, quorum sit illa simplex in agendo ueritas, non molesta.

[31] XXXI. (117) Et quoniam Stoicorum est facta mentio, Q. Aelius Tubero fuit illo tempore, $\mathrm{L}$. Pauli nepos; nullo in oratorum numero sed uita seuerus et congruens cum ea disciplina quam colebat, paulo etiam durior; qui quidem in triumuiratu iudicauerit contra P. Africani auunculi sui testimonium uacationem augures quo minus iudiciis operam darent non habere; sed ut uita sic oratione du- lou profundamente a república, quando nessa época eram homens eloquentíssimos os consulares Lúcio Crasso e Marco Antônio, não quis recorrer a nenhum dos dois. Ele discursou em sua própria defesa e Caio Cota falou brevemente, porque era filho de sua irmã - e ele, embora ainda fosse bastante jovem, discursou como um orador de verdade -, e também Quinto Múcio discursou de maneira clara e polida, como de costume, mas de nenhum modo com o vigor e a copiosidade que esse tipo de processo e a magnitude da causa exigiam. [116] Portanto, temos Rutílio entre os oradores estoicos, Escauro entre os antigos, todavia, podemos louvar ambos, pois por causa deles na nossa cidade nem mesmo esses gêneros foram privados do mérito oratório. Quero, de fato, que tal como no palco, assim também no fórum sejam louvados não só os que recorrem a um movimento corpóreo rápido e difícil, mas também os que são chamados de "estáticos", cuja atuação contém aquela naturalidade simples, sem afetação.

[117] E já que foi feita menção aos estoicos, Quinto Élio Tuberão, neto de Lúcio Paulo, viveu naquela época. Não se pode enumerá-lo entre os oradores, mas tinha uma vida austera e coerente com esta doutrina que cultivava, até um pouco mais rígida: quando era triúnviro proferiu sentença contra o testemunho de seu tio materno Públio Africano que afirmava não poderem os áugures serem dispensados da função de juízes. Mas como no modo de vida assim também no discurso era rígido, 
rus incultus horridus; itaque honoribus maiorum respondere non potuit. fuit autem constans ciuis et fortis et in primis Graccho molestus, quod indicat Gracchi in eum oratio; sunt etiam in Gracchum Tuberonis. is fuit mediocris in dicendo, doctissumus in disputando. (118) Tum Brutus: quam hoc idem in nostris contingere intellego quod in Graecis, ut omnes fere Stoici prudentissumi in disserendo sint et id arte faciant sintque architecti paene uerborum, idem traducti a disputando ad dicendum inopes reperiantur. unum excipio Catonem, in quo perfectissumo Stoico summam eloquentiam non desiderem, quam exiguam in Fannio, ne in Rutilio quidem magnam, in Tuberone nullam uideo fuisse. (119) Et ego: non, inquam, Brute, sine causa, propterea quod istorum in dialecticis omnis cura consumitur, uagum illud orationis et fusum et multiplex non adhibetur genus. tuus autem auunculus, quemadmodum scis, habet a Stoicis id, quod ab illis petendum fuit; sed dicere didicit a dicendi magistris eorumque more se exercuit. quod si omnia a philosophis essent petenda, Peripateticorum institutis commodius fingeretur oratio. (120) Quo magis tuum, Brute, iudicium probo, qui eorum (id est ex uetere Academia) philosophorum sectam secutus es, quorum in doctrina atque praeceptis disserendi ratio coniungi- inculto, rude. Por isso não foi capaz de corresponder às honras de seus antepassados. Por outro lado, era um cidadão firme e corajoso, e particularmente nocivo a Graco, como revela o discurso de Graco contra ele; também existem discursos de Tuberão contra Graco. Ele foi mediano na oratória, muito instruído no debate. [118] Bruto, então disse: - Percebo que entre os nossos conterrâneos acontece o mesmo que entre os gregos: quase todos os estoicos são muito sábios na argumentação e o fazem com arte e são como que arquitetos das palavras, quando passam da discussão para o discurso oratório se mostram pobres. Excetuo apenas Catão, nele, consumadíssimo estoico, não sinto falta de uma excelente eloquência, mas vejo que em Fânio ela era exígua, não muito grandiosa em Rutílio, inexistente em Tuberão. [119] E eu, então, continuei: - Não é sem razão, Bruto, uma vez que eles despendem toda preocupação na dialética, não recorrem àquele gênero de discurso livre e amplo e múltiplo. Mas o seu tio materno, como você sabe, toma dos estoicos aquilo que cabia buscar neles, mas aprendeu a discursar com os mestres de oratória e se exercitou à maneira destes. E se tudo tivesse de ser buscado nos filósofos, o discurso se produziria mais convenientemente pelos ensinamentos dos peripatéticos. [120] É por isso que eu aprovo tanto sua opção, Bruto, de seguir a escola daqueles filósofos cuja doutrina e cujos preceitos unem o método de argumentação à graça e copiosidade oratórias, ainda que essa prática habitual dos peripatéticos e 
tur cum suauitate dicendi et copia; quamquam ea ipsa Peripateticorum Academicorumque consuetudo in ratione dicendi talis est, ut nec perficere oratorem possit ipsa per sese nec sine ea orator esse perfectus. nam ut Stoicorum astrictior est oratio aliquantoque contractior quam aures populi requirunt, sic illorum liberior et latior quam patitur consuetudo iudiciorum et fori. (121) Quis enim uberior in dicendo Platone? Iouem sic (ut) aiunt philosophi, si Graece loquatur, loqui. quis Aristotele neruosior, Theophrasto dulcior? lectitauisse Platonem studiose, audiuisse etiam Demosthenes dicitur - idque apparet ex genere et granditate uerborum; dicit etiam in quadam epistula hoc ipse de sese - , sed et huius oratio in philosophiam translata pugnacior, ut ita dicam, uidetur et illorum in iudicia pacatior.

[32] XXXII. (122) Nunc reliquorum oratorum aetates, si placet, et gradus persequamur. Nobis uero, inquit Atticus, et uehementer quidem, ut pro Bruto etiam respondeam. Curio fuit igitur eiusdem aetatis fere sane illustris orator, cuius de ingenio ex orationibus eius existumari potest: sunt enim et aliae et pro Ser. Fuluio de incestu nobilis oratio. nobis quidem pueris haec omnium optima putabatur, quae uix iam comparet in hac turba nouorum dos acadêmicos no método oratório seja tal que ela por si só não é capaz de instruir completamente o orador nem pode haver orador completo sem ela. De fato, assim como o discurso dos estoicos é mais cerrado e um pouco mais condensado do que exigem os ouvidos do povo, do mesmo modo o discurso daqueles filósofos é mais livre e mais amplo do que permite a prática usual dos tribunais e do fórum. [121] Ora, quem tem um discurso mais abundante do que Platão? Dizem os filósofos que, se Júpiter falasse grego, falaria assim. Quem é mais vigoroso do que Aristóteles, mais agradável do que Teofrasto? Dizem que Demóstenes costumava ler Platão com afinco e que chegara a ser seu discípulo o que é manifesto pelo gênero e grandiosidade das palavras, ele mesmo também diz isso a seu próprio respeito numa carta -, mas, por um lado, seu discurso transferido para a filosofia parece, por assim dizer, mais combativo, por outro lado, o deles nos tribunais é mais pacífico.

[122] Agora, se lhes apraz, sigamos as gerações e as fases dos demais oradores. Sim, disse Ático, e muito, se é que eu posso responder também por Bruto. Pois bem, na mesma época, Curião foi sem dúvida um orador ilustre, de cujo engenho se pode ter uma ideia a partir de seus discursos: de fato, há alguns outros e aquele famoso discurso em defesa de Sérvio Fúlvio, acusado de relação sexual ilícita. Quando éramos meninos, esse discurso era considerado o melhor de todos, mas agora dificilmente pode ser comparado com essa multidão de 
uoluminum. (123) Praeclare, inquit Brutus, teneo qui istam turbam uoluminum effecerit. Et ego, inquam, intellego, Brute, quem dicas; certe enim et boni aliquid adtulimus iuuentuti, magnificentius quam fuerat genus dicendi et ornatius; et nocuimus fortasse, quod ueteres orationes post nostras non a me quidem - meis enim illas antepono — sed a plerisque legi sunt desitae. Me numera, inquit, in plerisque; quamquam uideo mihi multa legenda iam te auctore quae antea contemnebam. (124) Atqui haec, inquam, de incestu laudata oratio puerilis est locis multis: de amore de tormentis de rumore loci sane inanes, uerum tamen nondum tritis nostrorum hominum auribus nec erudita ciuitate tolerabiles. scripsit etiam alia nonnulla et multa dixit et inlustria et in numero patronorum fuit, ut eum mirer, cum et uita suppeditauisset et splendor ei non defuisset, consulem non fuisse.

[33] XXXIII. (125) Sed ecce in manibus uir et praestantissimo ingenio et flagranti studio et doctus a puero C. Gracchus: noli enim putare quemquam, Brute, pleniorem aut uberiorem ad dicendum fuisse. Et ille: sic prorsus, inquit, existumo atque novos escritos. [123] - Sei muito bem, observou Bruto, quem produziu essa multidão de escritos. - Sim, respondi, eu sei a quem você se refere, Bruto. É verdade que contribui com algo de bom para a juventude, um gênero oratório mais esplêndido e mais ornado do que havia antes, mas talvez eu a tenha prejudicado, porque os antigos discursos, depois que os meus entraram em circulação, deixaram de ser lidos, é verdade que não por mim, pois os coloco à frente dos meus, mas pela maioria. - Coloque-me entre essa maioria, retrucou. Embora eu perceba que, por causa de você, devo ler muitos escritos que antes eu desprezava. [124] - E, no entanto, continuei, nesse discurso sobre acusação de relação ilícita, tão elogiado, há muitas passagens pueris: sobre o amor, sobre as inquietações, sobre os boatos, tópicos bastante fúteis, que, contudo, eram aceitáveis quando os ouvidos dos nossos compatriotas ainda não eram experimentados e nossa cidade não era bem instruída. Escreveu também alguns textos e pronunciou muitos discursos célebres e teve um lugar entre os patronos, o que me faz admirar que ele, embora não só tivesse vivido bastante como também não lhe faltasse o esplendor, não tenha sido cônsul.

[125] Mas eis que nos deparamos com um homem de engenho eminentíssimo, de zelo ardente, instruído desde a infância, Caio Graco. E não pense, Bruto, que tenha havido alguém mais abundante e mais rico na oratória. E ele, então, disse: Penso exatamente desse maneira e dos an- 
istum de superioribus paene solum lego. Immo plane, inquam, Brute, legas censeo. damnum enim illius immaturo interitu res Romanae Latinaeque litterae fecerunt. (126) Utinam non tam fratri pietatem quam patriae praestare uoluisset. quam ille facile tali ingenio, diutius si uixisset, uel paternam esset uel auitam gloriam consecutus! eloquentia quidem nescio an habuisset parem neminem. grandis est uerbis, sapiens sententiis, genere toto grauis. manus extrema non accessit operibus eius: praeclare inchoata multa, perfecta non plane. legendus, inquam, est hic orator, Brute, si quisquam alius, iuuentuti; non enim solum acuere, sed etiam alere ingenium potest. (127) Huic successit aetati C. Galba, Serui illius eloquentissimi uiri filius, $\mathrm{P}$. Crassi eloquentis et iuris periti gener. laudabant hunc patres nostri, fauebant etiam propter patris memoriam, sed cecidit in cursu. nam rogatione Mamilia Iugurthinae coniurationis inuidia, cum pro sese ipse dixisset, oppressus est. exstat eius peroratio, qui epilogus dicitur; qui tanto in honore pueris nobis erat ut eum etiam edisceremus. hic, qui in conlegio sacerdotum esset, primus post Romam conditam iudicio publico est condemnatus. tigos ele é praticamente o único que eu leio. - Certamente, Bruto, respondi, creio que você deve lê-lo. De fato, sua morte prematura constituiu um prejuízo à república romana e às letras latinas. [126] Antes ele tivesse mostrado respeito não tanto a seu irmão quanto à patria. Com quanta facilidade, se tivesse vivido mais tempo, ele alcançaria, com o engenho que tinha, seja a glória de seu pai, seja a de seu avô. Ao menos quanto à eloquência, talvez ninguém o igualasse. Ele é grandioso nas palavras, sábio nos pensamentos, grave no todo. Às suas obras faltou o último toque, muitas delas muito bem iniciadas, não concluídas plenamente. Eu reitero, Bruto, esse orador deve ser lido pelos jovens, mais do que qualquer outro, pois não só é capaz de aguçar mas também de nutrir o engenho. [127] Depois de sua geração veio Caio Galba, filho daquele famoso e eloquentíssimo Sérvio, genro do eloquente e jurisperito Públio Crasso. Nossos pais o elogiavam, também o apoiavam em razão da lembrança de seu pai, mas caiu no meio do caminho. De fato, sucumbiu ao processo baseado na lei Mamília, suscitado pela hostilidade aos conjurados de Jugurta, embora tivesse discursado em sua própria defesa. Ainda existe a sua peroração, que é chamada de epílogo, ela, na nossa infância, gozava de tamanho prestígio que chagávamos a memorizá-la. Ele embora membro de um colégio sacerdotal, foi o primeiro a ser condenado por um tribunal público desde a fundação de Roma. 
[34] XXXIV. (128) P. Scipio, qui est in consulatu mortuus, non multum ille quidem nec saepe dicebat, sed et Latine loquendo cuiuis erat par et omnis sale facetiisque superabat. eius conlega L. Bestia bonis initiis orsus tribunatus - nam $P$. Popillium ui C. Gracchi expulsum sua rogatione restituit - , uir et acer et non indisertus, tristis exitus habuit consulatus. nam inuidiosa lege (Mamilia quaestio) C. Galbam sacerdotem et quattuor consularis, L. Bestiam C. Catonem Sp. Albinum ciuemque praestantissimum L. Opimium, Gracchi interfectorem, a populo absolutum, cum is contra populi studium stetisset, Gracchani iudices sustulerunt. (129) Huius dissimilis in tribunatu reliquaque omni uita ciuis improbus C. Licinius Nerua non indisertus fuit. C. Fimbria temporibus isdem fere sed longius aetate prouectus habitus est sane, ut ita dicam, luculentus patronus: asper maledicus, genere toto paulo feruidior atque commotior, diligentia tamen et uirtute animi atque uita bonus auctor in senatu; idem tolerabilis patronus nec rudis in iure ciuili et cum uirtute tum etiam ipso orationis genere liber; cuius orationes pueri legebamus, quas iam reperire uix possumus. (130) Atque etiam ingenio et sermone eleganti, ualetudine incommoda C. Sextius Caluinus fuit; qui etsi, cum remiserant dolo-
[128] Públio Cipião, que morreu durante seu consulado, não discursava muito nem mesmo com frequência, é verdade, mas, a um só tempo, não ficava atrás de ninguém na pureza do latim e era superior a todos na espirituosidade e nos gracejos. Seu colega Lúcio Béstia, homem enérgico e não desarticulado, depois de um bom início de tribunado - pois, em razão de sua lei, reconduziu Públio Popílio, expulso pela violência de Caio Graco - , teve um triste fim em seu consulado. Com efeito, em razão daquela odiosa lei, os juízes simpatizantes de Graco baniram o sacerdote Caio Galba e quatro consulares, Lúcio Béstia, Caio Catão, Spúrio Albino e um cidadão notabilíssimo, Lúcio Opímio, assassino de Graco, absolvido pelo povo, embora ele tivesse se posicionado contra a causa do povo. [129] Diferente dele no tribunado e, em todos demais aspectos da vida, um cidadão ímprobo, Caio Licínio Nerva não era desarticulado. Caio Fímbria, quase na mesma época, porém bem mais avançado na idade, era tido, por assim dizer, como patrono esplêndido: áspero, maledicente, demasiado fervoroso no todo e impetuoso; no entanto, por sua diligência, excelência de caráter e conduta, detinha bastante autoridade no senado; era também um patrono razoável, não ignorante no direito civil e franco tanto pelo caráter como pelo próprio gênero oratório. Quando meninos, líamos seus discursos, que agora mal conseguimos encontrar. [130] E também foi orador de engenho e de linguagem elegante mas de saúde debi- 
res pedum, non deerat in causis, tamen id non saepe faciebat. itaque consilio eius, cum uolebant, homines utebantur, patrocinio, cum licebat. isdem temporibus M. Brutus, in quo magnum fuit, Brute, dedecus generi uestro, qui, cum tanto nomine esset patremque optimum uirum habuisset et iuris peritissimum, accusationem factitauerit, ut Athenis Lycurgus. is magistratus non petiuit sed fuit accusator uehemens et molestus, ut facile cerneres naturale quoddam stirpis bonum degenerauisse uitio deprauatae uoluntatis. (131) Atque eodem tempore accusator de plebe L. Caesulenus fuit, quem ego audiui iam senem, cum ab L. Sabellio multam lege Aquilia de iustitia petiuisset. non fecissem hominis paene infimi mentionem, nisi iudicarem qui suspiciosius aut criminosius diceret audiuisse me neminem.

[35] XXXV. doctus etiam Graecis T. Albucius uel potius paene Graecus. loquor, ut opinor; sed licet ex orationibus iudicare. fuit autem Athenis adulescens, perfectus Epicureus euaserat, minime aptum ad dicendum genus. (132) Iam Q. Catulus non antiquo illo more sed hoc nostro, nisi quid fieri potest perfectius, eruditus. multae litterae, summa non uitae solum atque naturae sed orati- litada Caio Séstio Calvino, que, quando as dores da gota diminuiam, não se ausentava dos processos, embora não o fizesse com frequência. Assim, as pessoas se valiam de sua consulta, quando queriam, de sua defesa, quando era possível. Na mesma época viveu Marco Bruto, grande desonra de sua estirpe, Bruto, que, embora tivesse um nome tão ilustre e um homem excelente e muito versado no direito como pai, costumava exercer o papel de acusador, como Licurgo em Atenas. Ele não se candidatou a nenhuma magistratura, mas foi um acusador veemente e exasperado, de modo que facilmente se pode perceber como a qualidade absolutamente natural de uma estirpe se degenerou por culpa de uma intenção depravada. [131] E no mesmo período, Lúcio Cesuleno, de origem plebeia, foi acusador, que pude ouvir sendo ele já velho, quando propôs uma multa para Lúcio Saufeio com base na lei Aquília. Não teria feito menção a um homem quase insignificante, se eu não julgasse não ter ouvido ninguém que ao discursar suscitava maior suspeita ou maior convicção de culpa do que ele.

Também Tito Albúcio foi instruído nas letras gregas, ou antes, era quase um grego. Falo segundo a minha opinião, mas é possível avaliar a partir de seus discursos. Viveu a juventude em Atenas, saira de lá um perfeito epicurista, um tipo de gente nada adequado à oratória.[132] Já Quinto Cátulo era bem instruído não à maneira antiga mas à de nosso tempo, senão por poder ser mais aperfeiçoada. Muito versado nas letras, extremamente amável não só 
onis etiam comitas, incorrupta quaedam Latini sermonis integritas; quae perspici cum ex orationibus eius potest tum facillume ex eo libro, quem de consulatu et de rebus gestis suis conscriptum molli et Xenophonteo genere sermonis misit ad A. Furium poetam familiarem suum; qui liber nihilo notior est quam illi tres, de quibus ante dixi, Scauri libri. (133) Tum Brutus: mihi quidem, inquit, nec iste notus est nec illi; sed haec mea culpa est, numquam enim in manus inciderunt. nunc autem et a te sumam et conquiram ista posthac curiosius. Fuit igitur in Catulo sermo Latinus; quae laus dicendi non mediocris ab oratoribus plerisque neglecta est. nam de sono uocis et suauitate appellandarum litterarum, quoniam filium cognouisti, noli exspectare quid dicam. quamquam filius quidem non fuit in oratorum numero; sed non deerat ei tamen in sententia dicenda cum prudentia tum elegans quoddam et eruditum orationis genus. (134) Nec habitus est tamen pater ipse Catulus princeps in numero patronorum; sed erat talis ut, cum quosdam audires qui tum erant praestantes, uideretur esse inferior, cum autem ipsum audires sine comparatione, non modo contentus esses, sed melius non quaereres. (135) Q. Metellus Numidicus et eius conlega M. Silanus dicebant de re publica quod esset illis uiris et consulari no modo de vida e no caráter mas também no discurso, de uma pureza imaculada na falar latim, que se pode perceber, quer em seus discursos, quer mais facilmente naquele livro sobre seu consulado e sobre os seus feitos que escreveu de modo delicado e à maneira da linguagem de Xenofonte e dedicou ao seu amigo o poeta Aulo Fúrio. Esse livro não é mais conhecido do que aqueles três livros de Escauro, sobre os quais falei antes. [133] Bruto, então, disse: - Na verdade, não me é conhecido nem este nem aquele, mas isso é minha culpa, é que nunca cairam em minhas mãos. Mas, agora, não só lhe tomarei emprestado mas também procurarei essas obras com mais atenção depois disso. - Havia em Cátulo, como dizia, uma dicção propriamente latina, mérito que não é pequeno na oratória, negligenciado pela maioria dos oradores. Quanto à entonação da voz e à beleza da pronúncia das palavras, já que você conheceu o seu filho, não espere que eu fale a respeito dele. Embora seu filho não estivesse na categoria dos oradores, ao pronunciar sua sentença no senado, não lhe faltava sabedoria nem aquele modo de falar elegante e culto. [134] Contudo, nem mesmo o próprio pai Cátulo estava na categoria dos principais patronos, mas era de tal natureza que, quando se ouviam aqueles que naquele momento se sobressaiam, parecia ser inferior, mas quando ele era ouvido sem ninguém para comparar, não só contentavam-se com ele, mas não procuravam alguém melhor. [135] Quinto Metelo Numídico e seu colega Marco Si- 
dignitati satis. M. Aurelius Scaurus non saepe dicebat, sed polite; Latine uero in primis est eleganter locutus. quae laus eadem in A. Albino bene loquendi fuit; nam flamen Albinus etiam in numero est habitus disertorum; Q. etiam Caepio, uir acer et fortis, cui fortuna belli crimini, inuidia populi calamitati fuit.

[36] XXXVI. (136) Tum etiam C.

L. Memmii fuerunt oratores mediocres, accusatores acres atque acerbi; itaque in iudicium capitis multos uocauerunt, pro reis non saepe dixerunt. Sp. Thorius satis ualuit in populari genere dicendi, is qui agrum publicum uitiosa et inutili lege uectigali leuauit. M. Marcellus Aesernini pater non ille quidem in patronis, sed et in promptis tamen et non inexercitatis ad dicendum fuit, ut filius eius P. Lentulus. (137) L. etiam Cotta praetorius in mediocrium oratorum numero, dicendi non ita multum laude processerat, sed de industria cum uerbis tum etiam ipso sono quasi subrustico persequebatur atque imitabatur antiquitatem. Atque ego et in hoc ipso Cotta et in aliis pluribus intellego me non ita disertos homines et rettulisse in oratorum numerum et relaturum. est enim propositum conligere eos, qui lano, nas deliberações políticas, discursavam de modo condizente com o caráter e a dignidade consular deles. Marco Aurélio Escauro não discursava com frequência, mas com refinamento, quanto a pronúncia do latim, estava entre os primeiros na elegância. E tinha esse mesmo mérito de falar bem Aulo Albino. Quanto ao flâmine Albino, também estava incluído na categoria dos bem articulados. Também havia Quinto Cepião, homem enérgico e vigoroso, cujo infotúnio na guerra o encriminou, a hostilidade do povo o arruinou.

[136] Também na mesma época foram oradores modestos Caio e Lúcio Mêmio, acusadores enérgicos e acerbos. E assim citaram muitas pessoas em processos capitais, não discursaram muitas vezes em defesa de acusados. Espúrio Tório destacouse bastante no gênero oratório popular, foi ele quem desonerou as terras públicas de um tributo criado por uma lei danosa e inútil. Marco Marcelo, pai de Esernino, não era alguém que estava entre os patronos, é verdade, contudo, estava entre os hábeis e não desprovidos de experiência na oratória, como seu filho Públio Lêntulo. [137] Também Lúcio Cota, de grau pretoriano, pertencia à categoria dos oradores modestos, não havia alcançado muito prestígio na oratória, mas procurava imitar deliberadamante o modo arcaico de falar não só nas palavras mas também na própria pronúncia um tanto rústica. $\mathrm{E}$ eu sei que, tanto no caso do próprio Cota como no de muitos outros, eu inclui homens não tão bem articulados na categoria de ora- 
hoc munere in ciuitate functi sint, ut tenerent oratorum locum; quorum quidem quae fuerit ascensio et quam in omnibus rebus difficilis optimi perfectio atque absolutio ex eo quod dicam existimari potest. (138) Quam multi enim iam oratores commemorati sunt et quam diu in eorum enumeratione uersamur, cum tamen spisse atque uix, ut dudum ad Demosthenen et Hyperiden, sic nunc ad Antonium Crassumque peruenimus. nam ego sic existimo, hos oratores fuisse maximos et in his primum cum Graecorum gloria Latine dicendi copiam aequatam.

[37] XXXVII. (139) Omnia ueniebant Antonio in mentem; eaque suo quaeque loco, ubi plurimum proficere et ualere possent, ut ab imperatores equites, pedites, levis armatura, sic ab illo in maxume opportunis orationis partibus conlocabantur. erat memoria summa, nulla meditationis suspicio; imparatus semper adgredi ad dicendum videbatur, sed ita erat paratus, ut iudices illo dicente non numquam uideretur non satis parati ad cavendum fuisse. (140) uerba ipsa non illa quidem elegantissimo sermone; itaque diligenter loquendi laude caruit - neque tamen esta admodum inquinate locutus sed illa, quae proprie laus oratoris est in verbis. nam ipsum Latine lo- dores e continuarei a fazê-lo. É que meu propósito é reunir aqueles que na nossa cidade exerceram uma função tal que tiveram que ocupar o lugar de oradores, é possível perceber a partir daquilo que irei dizer quão grande foi o avanço deles e o quanto é difícil em todas as coisas a perfeição e a completude da excelência. [138] De fato, que grande número de oradores já foi lembrado e há quanto tempo nos ocupamos em enumerá-los. E, no entanto, só lentamente e a custo é que, tal como alcançamos antes Demóstenes e Hipérides, chegamos assim também agora a Antônio e Crasso. De fato, eu penso o seguinte: esses foram os maiores oradores, e com eles pela primeira vez a copiosidade da oratória latina se igualou a glória dos gregos.

[139] Todos os argumentos vinham à mente de Antônio, e cada um no exato lugar onde pudesse ter mais proveito e força: tal como um general ordena os cavaleiros, a infantaria, as tropas ligeiras, assim ele os dispunha nas partes mais oportunas do discurso. Sua memória era excelente, sem qualquer suspeita de premeditação. Sempre parecia começar a discursar despreparado, mas estava de tal forma preparado que os juízes, enquanto discursava, por vezes pareciam não estar preparados o bastante para se protegerem. [140] É bem verdade que suas palavras em si não pertenciam à linguagem mais refinada, e por isso faltava-lhe o mérito de falar cuidadosamente - ainda que não tenha falado de modo totalmente grosseiro - , mas faltavalhe o mérito que é próprio do orador e que 
qui est illud quidem [est], ut paulo ante dixi, in magna laude ponendum, sed non tam sua sponte quam quod est a plerisque neglectum: non enim tam praeclaru est scire Latine quam turpe nescire, neque tam mihi oratoris boni quam civis Romani proprium videtur. Sed tamen Antonius in uerbis eligendis, neque id ipsum tam leporis causa quam ponderis, et conlocandis et comprensione devinciendis nihil non ad rationem et tamquam ad artem dirigebat; uerum multo magis hoc idem in sententiarum ornamentis et conformationibus. (141) Quo in genere quia praestat omnibus Demosthenes, idcirco a doctis oratorum est princeps iudicatus. $\sigma \chi \bar{n} \mu \alpha \tau \alpha$ enim quae uocant Graeci, ea maxume ornant oratorem eaque non tam in uerbis pingendis habent pondus quam in inluminandis sententiis. [38] XXXVIII. Sed cum haec magna in Antonio tum actio singularis; quae si partienda est in gestum atque uocem, gestus erat non uerba exprimens, sed cum sententiis congruens: manus humeri latera supplosio pedis status incessus omnisque motus cum uerbis sententiisque consentiens; uox permanens, uerum subrauca natura. sed hoc uitium huic uni in bonum conuertebat. (142) Habebat enim flebile quiddam in questionibus aptumque cum ad fidem faciendam tum ad misericordiam commouendam: ut uerum ui- reside nas palavras. É que, por si só, falar bom latim é, de fato, como disse há pouco, algo a que se deve conferir o maior mérito, mas não tanto considerado em si mesmo, quanto porque é algo negligenciado pela maioria; com efeito, não é tão extraordinário saber latim quanto é vergonhoso não saber; e não me parece tanto algo próprio de um bom orador quanto de um cidadão romano. Quanto a Antônio, no entanto, fosse na escolha das palavras - e isso não tanto pela beleza quanto pela força - , fosse na disposição, fosse no encadeamento da frase, não havia nada que não ordenasse segundo um método e, por assim dizer, uma arte; mas isso acontecia muito mais no caso dos ornamentos e figuras de pensamento. [141] Por superar a todos nesse aspecto, Demóstenes é considerado pelos doutos o primeiro dos oradores. Com efeito, aquilo que os gregos chamam de $\sigma \chi \eta \dot{\eta} \mu \alpha \tau \alpha$ é o que confere maior ornato ao discurso e que é eficaz não tanto em ressaltar as palavras quanto em iluminar os pensamentos. Mas tanto isso era grandioso como sua atuação, singular, se cumpre dividi-la em gesto e voz: o gesto não exprimia as palavras mas convergia com os pensamentos: as mão, os ombros, os flancos, a batida do pé, a postura, o passo e todo o movimento concordava com as palavras e pensamentos; sua voz era estável, porém rouca por natureza. Mas esse defeito somente nele convertia-se em qualidade. [142] Com efeito, era um tanto lamurioso nos interrogatórios e apto não só a inspirar confiança como também a sus- 
deretur in hoc illud, quod Demosthenem ferunt ei, qui quaesiuisset quid primum esset in dicendo, actionem, quid secundum, idem et idem tertium respondisse. nulla res magis penetrat in animos eosque fingit format flectit, talesque oratores uideri facit, quales ipsi se uideri uolunt. (143) Huic alii parem esse dicebant, alii anteponebant L. Crassum. illud quidem certe omnes ita iudicabant, neminem esse, qui horum altero utro patrono cuiusquam ingenium requireret. equidem quamquam Antonio tantum tribuo quantum supra dixi, tamen Crasso nihil statuo fieri potuisse perfectius. erat summa grauitas, erat cum grauitate iunctus facetiarum et urbanitatis oratorius, non scurrilis lepos, Latine loquendi accurata et sine molestia diligens elegantia, in disserendo mira explicatio; cum de iure ciuili, cum de aequo et bono disputaretur, argumentorum et similitudinum copia.

[39] XXXIX. (144) Nam ut Antonius coniectura mouenda aut sedanda suspicione aut excitanda incredibilem uim habebat: sic in interpretando in definiendo in explicanda aequitate nihil erat Crasso copiosius; idque cum saepe alias tum apud centumuiros in M. Curi causa cognitum est. (145) Ita enim multa tum contra scriptum pro aequo et bono dixit, ut hominem acutissimum Q. Scaeuolam citar a comiseração; de modo que parece verdade o que se conta de Demóstenes que ao ter sido questionado sobre o que era mais importante na eloquência, respondeu, em primeiro lugar a ação, em segundo a ação, em terceiro a ação. Nada penetra mais nos ânimos e os forja, forma, dobra e faz com que os oradores pareçam tais como eles próprios querem parecer. [143] Uns equiparavam-no, outros colocavam-no atrás de Crasso. O fato é que todos reputavam que não havia ninguém que, tendo um dos dois como patrono, tivesse necessidade do engenho de outrem. De minha parte, embora atribua a Antônio tudo o que disse antes, penso que não podia haver nada de mais perfeito que Crasso. Havia nele extrema seriedade, havia junto com a seriedade um humor oratório não bufonesco, próprio dos gracejos e da urbanidade, uma linguagem apurada e uma elegância cuidadosa, sem afetação - ao argumentar, sua exposição era admirável; quando se tratava de discursar sobre direito civil, sobre o justo e o bom, fazia-o com abundância de argumentos e analogias.

[144] De fato, tal como Antônio possuía incrível capacidade para propor uma conjectura e mitigar ou provocar uma suspeita, assim também, na interpretação, na definição, no desenvolvimento dos princípios do justo, ninguém era mais eloquente que Crasso, o que não só já foi reconhecido muitas vezes, mas sobretudo diante dos centúnviros, na causa de Mânio Curio. [145] É que discursou tão bem contra a letra da lei em favor do justo e do bom, que 
et in iure, in quo illa causa uertebatur, paratissimum obrueret argumentorum exemplorumque copia; atque ita tum ab his patronis aequalibus et iam consularibus causa illa dicta est, cum uterque ex contraria parte ius ciuile defenderet, ut eloquentium iuris peritissimus Crassus, iuris peritorum eloquentissimus Scaeuola putaretur. qui quidem cum peracutus esset ad excogitandum quid in iure aut in aequo uerum aut esset aut non esset, tum uerbis erat ad rem cum summa breuitate mirabiliter aptus. (146) Quare sit nobis orator in hoc interpretandi explanandi edisserendi genere mirabilis sic ut simile nihil uiderim; in augendo in ornando in refellendo magis existumator metuendus quam admirandus orator. uerum ad Crassum reuertamur. [40] XL. (147) Tum Brutus: etsi satis, inquit, mihi uidebar habere cognitum Scaeuolam ex iis rebus, quas audiebam saepe ex C. Rutilio, quo utebar propter familiaritatem Scaeuolae nostri, tamen ista mihi eius dicendi tanta laus nota non erat; itaque cepi uoluptatem tam ornatum uirum tamque excellens ingenium fuisse in nostra re publica. (148) Hic ego: noli, inquam, Brute, existimare his duobus quicquam fuisse in nostra ciuitate praestantius. nam ut paulo ante dixi consultorum alterum disertissimum, disertorum alterum consultissimum fuisse, sic in reliquis rebus ita esmagou com a abundância de argumentos e exemplos um homem extremamente perspicaz como Quinto Cévola e extremamente preparado em matéria de direito, no qual aquela causa consistia. E de tal forma aquela causa foi então defendida por esses patronos contemporâneos e já consulares, quando ambos defendiam o direito civil a partir de pontos de vista contrários, que Crasso foi considerado o mais perito em direito dos eloquentes, Cévola, o mais eloquente dos peritos em direito. Este, por sua vez, não só era perspicaz em distinguir no direito e no justo o verdadeiro do falso, mas também conseguia, admiravelmente, adequar as palavras ao argumento com extrema brevidade. [146] Por causa disso ele é para nós, no âmbito da interpretação, da explicação, da discussão, um orador admirável; tal como ele eu nunca vi - na amplificação, na ornamentação, na refutação, era mais um crítico temível que um admirável orador. Mas voltemos a Crasso. [147]Então, Bruto disse: — Embora tivesse a impressão de conhecer suficientemente Cévola com base no que costumava ouvir de Caio Rutílio, com quem eu convivia em razão de sua amizade com nosso caro Cévola, não sabia que era tanta sua reputação na eloquência. Por isso, fico satisfeito por ter havido em nossa república um homem tão honrado e um engenho tão excelso. [148] Ao que eu disse: - não pense, Bruto, que em nossa cidade haja alguém superior a esses dois; pois, como disse há pouco, um foi o mais bem articulado dos jurisconsultos, o outro, o mais juriscon- 
dissimiles erant inter sese, statuere ut tamen non posses utrius te malles similiorem. Crassus erat elegantium parcissimus, Scaeuola parcorum elegantissimus; Crassus in summa comitate habebat etiam seueritatis satis, Scaeuolae multa in seueritate non deerat tamen comitas. (149) Licet omnia hoc modo; sed uereor ne fingi uideantur haec, ut dicantur a me quodam modo; res se tamen sic habet. cum omnis uirtus sit, ut uestra, Brute, uetus Academia dixit, mediocritas, uterque horum medium quiddam uolebat sequi; sed ita cadebat, ut alter ex alterius laude partem, uterque autem suam totam haberet. (150) Tum Brutus: cum ex tua oratione mihi uideor, inquit, bene Crassum et Scaeuolam cognouisse, tum de te et de Ser. Sulpicio cogitans esse quandam uobis cum illis similitudinem iudico. Quonam, inquam, istuc modo? Quia mihi et tu uideris, inquit, tantum iuris ciuilis scire uoluisse quantum satis esset oratori et Seruius eloquentiae tantum adsumpsisse, ut ius ciuile facile possit tueri; aetatesque uostrae ut illorum nihil aut non fere multum differunt.

[41] XLI. (151) Et ego: de me, inquam, dicere nihil est necesse; de Seruio autem et tu probe dicis et ego dicam quod sentio. non enim facile quem dixerim plus studi quam sulto dos bem articulados, tal como eram nos outros aspectos tão diferentes entre si, que no entanto, você não pode determinar a qual dos dois você prefere se assemelhar. Crasso era o mais sóbrio dos elegantes, Cévola, o mais elegante dos sóbrios. Crasso, em sua extrema amabilidade, era também suficientemente austero, a Cévola, em sua demasiada austeridade, não faltava, no entanto, amabilidade. [149] E assim por diante, mas temo que isso pareça ter sido forjado para que eu me exprima de certa maneira, e, no entanto, é exatamente isso. Visto que, como diz sua antiga Academia, Bruto, toda virtude é uma mediania, ambos queriam seguir esse meio-termo, mas acontece que um possuía em parte o mérito do outro, cada um, porém, mantinha o seu no todo. [150] Então, Bruto disse: Por um lado, o seu discurso me parece ter dado um bom conhecimento de Crasso e Cévola; por outro, refletindo sobre você e Sérvio Sulpício, penso que há entre vocês certa semelhança com eles. - $\mathrm{O}$ que você quer dizer? Perguntei. - É que não só me parece, respondeu, que você queria conhecer tanto direito civil quanto bastasse a um orador, mas também que Sulpício praticava a eloquência para que pudesse examinar mais facilmente o direito civil; e suas idades, como as deles, nada diferem ou não diferem muito.

[151] E eu disse: não é o caso de falar sobre mim, porém sobre Sérvio; você fala muito bem, e eu falarei o que penso. É que não terei dificuldade em encontrar quem se aplique com mais zelo que ele 
illum et ad dicendum et ad omnes bonarum rerum disciplinas adhibuisse. nam et in isdem exercitationibus ineunte aetate fuimus et postea una Rhodum ille etiam profectus est, quo melior esset et doctior; et inde ut rediit, uidetur mihi in secunda arte primus esse maluisse quam in prima secundus. atque haud scio an par principibus esse potuisset; sed fortasse maluit, id quod est adeptus, longe omnium non eiusdem modo aetatis sed eorum etiam qui fuissent in iure ciuili esse princeps. (152) Hic Brutus: ain tu? inquit: etiamne Q. Scaeuolae Seruium nostrum anteponis? Sic enim, inquam, Brute, existumo, iuris ciuilis magnum usum et apud Scaeuolam et apud multos fuisse, artem in hoc uno; quod numquam effecisset ipsius iuris scientia, nisi eam praeterea didicisset artem, quae doceret rem uniuersam tribuere in partes, latentem explicare definiendo, obscuram explanare interpretando, ambigua primum uidere, deinde distinguere, postremo habere regulam, qua uera et falsa iudicarentur et quae quibus propositis essent quaeque non essent consequentia. (153) Hic enim adtulit hanc artem omnium artium maxumam quasi lucem ad ea, quae confuse ab aliis aut respondebantur aut agebantur. [42] XLII. Dialecticam mihi uideris dicere, inquit. Recte, inquam, intellegis; sed adiunxit etiam et lit- não só na oratória, como também em todas as boas doutrinas. O fato é que não só nos submetemos aos mesmos exercícios no período inicial, mas, em seguida, ele também partiu para Rodes, para se tornar melhor e mais instruído; e, quando de lá voltou, parecia-me que preferia ser na segunda arte o primeiro, a ser na primeira o segundo. Ademais, não sei se poderia ser colocado entre os primeiros, mas talvez tenha preferido ser, de longe, o primeiro em direito civil entre todos, não apenas de sua época como também dos que existiram antes, o que conseguiu. [152] Bruto, então, perguntou - Acaso você também coloca nosso querido Sérvio à frente de Quinto Cévola? - Sim, respondi, realmente, Bruto, creio que havia tanto em Cévola, quanto em outros, uma grande prática no direito civil, conhecimento teórico em um apenas; o que jamais teria alcançado com o conhecimento apenas do direito, a não ser que tivesse aprendido, além disso, aquela arte que ensina a dividir a questão geral em espécies, a explicar o obscuro com interpretações, perceber primeiro as ambiguidades, depois distingui-las, e, enfim, estabelecer um critério com o qual se julguem o verdadeiro e o falso, e quais as consequências se seguem ou não de tais premissas. [153] Ele, de fato, trouxe a esta arte, a maior de todas as artes, como que uma luz àquilo que confusamente era feito por outros nas consultas e nos processos. - Parece-me que você se refere à dialética, ele disse. — Você notou bem, continuei, mas juntou também tanto o conhecimento das letras, quanto a 
terarum scientiam et loquendi elegantiam, quae ex scriptis eius, quorum similia nulla sunt, facillime perspici potest. (154) Cumque discendi causa duobus peritissumis operam dedisset, L. Lucilio Balbo C. Aquilio Gallo, Galli hominis acuti et exercitati promptam et paratam in agendo et in respondendo celeritatem subtilitate diligentiaque superauit; Balbi docti et eruditi hominis in utraque re consideratam tarditatem uicit expediendis conficiendisque rebus. sic et habet quod uterque eorum habuit, et expleuit quod utrique defuit.

(155) Itaque ut Crassus mihi uidetur sapientius fecisse quam Scaeuola - hic enim causas studiose recipiebat, in quibus a Crasso superabatur; ille se consuli nolebat, ne qua in re inferior esset quam Scaeuola sic Seruius sapientissume, cum duae ciuiles artes ac forenses plurimum et laudis haberent et gratiae, perfecit ut altera praestaret omnibus, ex altera tantum adsumeret, quantum esset et ad tuendum ius ciuile et ad obtinendam consularem dignitatem satis. (156) Tum Brutus: ita prorsus, inquit, et antea putabam - audiui enim nuper eum studiose et frequenter Sami, cum ex eo ius nostrum pontificium, qua ex parte cum iure ciuili coniunctum esset, uellem cognoscere - et nunc meum iudicium multo magis confirmo testimonio et iudicio tuo; simul illud gaudeo, quod elegância oratória, que facilmente se percebe em seus escritos, aos quais nada se assemelha. [154] E, quando a fim de se instruir, frequentou dois dos maiores peritos, Lúcio Lucílio Balbo e Caio Aquílio Galo; de Galo, homem perspicaz e experiente, superou a fluente e ágil destreza nos processos e nos pareceres com sua sagacidade e zelo; de Balbo, homem douto e erudito, venceu a morosidade reflexiva em ambas as matérias, solucionando e finalizando as questões. Assim, não só possui o que ambos possuíram como também completou o que em ambos faltou.

[155] Por isso, assim como Crasso me parece ter agido com mais prudência que Cévola - pois este aceitava as causas com empenho, nas quais era superado por Crasso; aquele não queria dar pareceres, para que não fosse inferior a Cévola nesse aspecto -, assim também Sérvio, muito sabiamente, em razão de as duas artes civis e forenses gozarem não apenas de grande renome mas também de credibilidade, fez com que em uma superasse a todos, na outra se aplicasse o quanto fosse suficiente não só para fazer valer o direito civil como também para conservar o prestígio consular. [156] Então, Bruto disse: — Exatamente assim não só eu pensava antes pois o ouvi há pouco com zelo e assiduidade, visto que desejava aprender com ele o nosso direito pontifical, em suas partes comuns com o direito civil -, como também agora ratifico ainda mais minha opinião com seu testemunho e sua opinião; ao 
et aequalitas uestra et pares honorum gradus et artium studiorumque quasi finitima uicinitas tantum abest ab obtrectatione et inuidia, quae solet lacerare plerosque, uti ea non modo non exulcerare uestram gratiam, sed etiam conciliare uideatur. quali enim te erga illum perspicio, tali illum in te uoluntate iudicioque cognoui. (157) Itaque doleo et illius consilio et tua uoce populum Romanum carere tam diu; quod cum per se dolendum est tum multo magis consideranti ad quos ista non translata sint, sed nescio quo pacto deuenerint. Hic Atticus: dixeram, inquit, a principio, de re publica ut sileremus; itaque faciamus. nam si isto modo uolumus singulas res desiderare, non modo querendi sed ne lugendi quidem finem reperiemus.

[43] XLIII. (158) Pergamus ergo, inquam, ad reliqua et institutum ordinem persequamur. paratus igitur ueniebat Crassus, exspectabatur audiebatur; a principio statim, quod erat apud eum semper accuratum, exspectatione dignus uidebatur. non multa iactatio corporis, non inclinatio uocis, nulla inambulatio, non crebra supplosio pedis; uehemens et interdum irata et plena iusti doloris oratio, multae et cum grauitate facetiae; quodque difficile est, idem et perornatus et perbreuis; iam in alter- mesmo tempo me alegra o fato de que não só a mesma idade, como também iguais em graus de magistratura, bem como uma, por assim dizer, estreita afinidade nas artes e nos estudos, afaste tanto a maledicência e a inveja que costuma dilacerar muitos, o que parece não só não esfriar sua amizade, mas sim cultivá-la. De fato, tal como percebo em você por ele, assim também sei do apreço e estima que ele tem por você. [157] Por isso, lamento que o povo romano esteja privado há tanto tempo não só da prudência dele como também da sua voz, o que não apenas é lamentável em si, mas sobretudo muito mais quando se vê para quem estas atividades foram, eu não diria, transferidas, mas, não sei como, foram parar. Então, Ático interrompeu: - Eu havia dito no início que não falaríamos sobre política. Façamos assim. De fato, se deste modo queremos deplorar a ausência de cada coisa, não encontraremos fim para as queixas nem sequer para os prantos.

[158] - Continuemos, então, disse, no que resta, dando prosseguimento à ordem estabelecida. Crasso chegava, então, preparado, era esperado, era ouvido; já no proêmio, em que ele sempre se esmerava, se mostrava digno de atenção. Não agitava muito o corpo, não abaixava o tom da voz, não andava de um lado para o outro, não batia o pé com frequência; seu discurso era veemente e, às vezes, furioso e cheio de uma emoção legítima; e fazia muitos gracejos com seriedade, e, o que é difícil, era ao mesmo tempo muito ornado e muito breve; nas altercações, além disso, 
cando inuenit parem neminem. (159) Versatus est in omni fere genere causarum; mature in locum principum oratorum uenit. accusauit C. Carbonem eloquentissimum hominem admodum adulescens; summam ingeni non laudem modo sed etiam admirationem est consecutus. (160) defendit postea Liciniam uirginem, cum annos xxuii natus esset. in ea ipsa causa fuit eloquentissimus orationisque eius scriptas quasdam partes reliquit. uoluit adulescens in colonia Narbonensi causae popularis aliquid adtingere eamque coloniam, ut fecit, ipse deducere; exstat in eam legem senior, ut ita dicam, quam aetas illa ferebat oratio. multae deinde causae; sed ita tacitus tribunatus ut, nisi in eo magistratu cenauisset apud praeconem Granium idque nobis bis narrauisset Lucilius, tribunum plebis nesciremus fuisse.

(161) Ita prorsus, inquit Brutus; sed ne de Scaeuolae quidem tribunatu quicquam audiuisse uideor et eum collegam Crassi credo fuisse. Omnibus quidem aliis, inquam, in magistratibus, sed tribunus anno post fuit eoque in rostris sedente suasit Seruiliam legem Crassus; nam censuram sine Scaeuola gessit: eum enim magistratum nemo umquam Scaeuolarum petiuit. sed haec Crassi cum edita oratio est, quam te saepe legisse certo scio, quattuor et triginta tum habebat não encontrava ninguém que lhe igualasse. [159] Ocupou-se de praticamente todo o tipo de causas, tornando-se prontamente um orador de primeira categoria. Ainda muito jovem, acusou um homem extremamente eloquente, Caio Carbão, e obteve para seu engenho não só incrível glória mas também admiração. [160] Depois disso, defendeu a sacerdotisa de Vesta, Licínia, quando tinha 27 anos. Nessa mesma causa foi muitíssimo eloquente e deixou escritas algumas partes desse discurso. Ainda jovem, procurou se engajar em uma causa popular e, tal como o fez, estabelecer ele próprio a colônia; surge sobre essa lei um discurso característico de alguém mais velho, por assim dizer, do que a idade sugeria. Seguiram-se, depois, muitas causas, mas foi tão silencioso o tribunado que, se em sua magistratura não tivesse jantado com o pregoeiro Grânio, e Lucílio o tivesse narrado duas vezes, não saberíamos que fora tribuno da plebe.

[161] — Justamente isso, interrompeu Bruto; mas sobre o tribunado de Cévola creio também não ter ouvido nada e acho que ele foi companheiro de ofício de Crasso. - Sim, em todas as outras magistraturas, continuei, mas ele foi tribuno um ano depois, e, presidindo a tribuna, Crasso discursou em favor da lei Servília; com efeito, conduziu a censura sem Cévola; de fato, nunca um Cévola se candidatou a essa magistratura. Mas, quando esse discurso de Crasso, o qual bem sei que leste muito, foi publicado, ele tinha trinta e quatro anos, a exata diferença de idade entre nós. Com 
annos totidemque annis mihi aetate praestabat. his enim consulibus eam legem suasit quibus nati sumus, cum ipse esset Q. Caepione consule natus et C. Laelio, triennio ipso minor quam Antonius. quod idcirco posui, ut dicendi Latine prima maturitas in qua aetate exstitisset posset notari et intellegeretur iam ad summum paene esse perductam, ut eo nihil ferme quisquam addere posset, nisi qui a philosophia a iure ciuili ab historia fuisset instructior. [44] XLIV. (162) Erit, inquit M. Brutus, aut iam est iste quem exspectas? Nescio, inquam. sed est etiam L. Crassi in consulatu pro Q. Caepione defensiuncula non breuis ut laudatio, ut oratio autem breuis; postrema censoris oratio, qua anno duodequinquagesimo usus est. in his omnibus inest quidam sine ullo fuco ueritatis color; quin etiam comprensio et ambitus

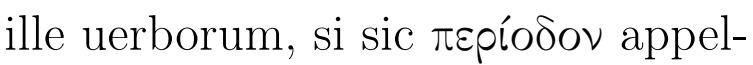
lari placet, erat apud illum contractus et breuis et in membra quaedam, quae $x \tilde{\omega} \lambda \alpha$ Graeci uocant, dispertiebat orationem libentius. (163) Hoc loco Brutus: quando quidem tu istos oratores, inquit, tanto opere laudas, uellem aliquid Antonio praeter illum de ratione dicendi sane exilem libellum, plura Crasso libuisset scribere: cum enim omnibus memoriam sui tum etiam disciplinam dicendi nobis reliquissent. nam Scaeuolae dicendi elegantiam satis ex iis orationibus, efeito, ele discursou em favor dessa lei no consulado em que eu nasci. Como, por sua vez, ele nasceu no consulado de Quinto Cepião e Caio Lélio, era apenas três anos mais jovem que Antônio; mencionei isso para que pudesse ser assinalada a época em que se manifestou a primeira maturidade da eloquência latina e se compreendesse que ela já foi conduzida quase que ao extremo, tal que quase nada lhe possa acrescentar, a não ser quem fosse melhor instruído em filosofia, em direito civil, em história. [162] - Existirá, perguntou Marco Bruto, ou já existe este que esperas? - Não sei, respondi, mas também é do consulado de Lúcio Crasso um pequeno discurso em defesa de Quinto Cepião, não breve como elogio, como discurso, porém, breve. Seu último discurso foi como censor, no ano em que completou quarenta e oito anos. Em todos eles há, sem nenhum artifício, um tom de realidade. Além disso, a frase e aquele circuito de palavras, ou se preferir chamar de זعpíoóos, era nisso conciso e breve, e com disposição dividia o discurso em certas partes, que os gregos chamam de $x \tilde{\omega} \lambda \alpha$. [163] Nesse momento, Bruto disse - Considerando que você louva tanto esses oradores, gostaria que tivesse aprazido a Antônio escrever mais que aquele livrinho sobre o método oratório, a Crasso, mais discursos; o fato é que teriam deixado não só uma recordação de si, mas também uma doutrina oratória. De fato, conhecemos bem a elegância oratória de Cévola a partir dos discursos que deixou. 
quas reliquit, habemus cognitam.

(164) Et ego: mihi quidem a pueritia quasi magistra fuit, inquam, illa in legem Caepionis oratio; in qua et auctoritas ornatur senatus, quo pro ordine illa dicuntur, et inuidia concitatur in iudicum et in accusatorum factionem, contra quorum potentiam populariter tum dicendum fuit. multa in illa oratione grauiter, multa leniter, multa aspere, multa facete dicta sunt; plura etiam dicta quam scripta, quod ex quibusdam capitibus expositis nec explicatis intellegi potest. ipsa illa censoria contra $\mathrm{Cn}$. Domitium conlegam non est oratio, sed quasi capita rerum et orationis commentarium paulo plenius. nulla est enim altercatio clamoribus umquam habita maioribus. (165) et uero fuit in hoc etiam popularis dictio excellens; Antoni genus dicendi multo aptius iudiciis quam contionibus. [45] XLV. Hoc loco ipsum Domitium non relinquo. nam etsi non fuit in oratorum numero, tamen pone satis in eo fuisse orationis atque ingeni, quo et magistratus personam et consularem dignitatem tueretur; quod idem de C- Coelio dixerim, industriam in eo summam fuisse summasque uirtutes, eloquentiae tantum, quod esset in rebus priuatis amicis eius, in re publica ipsius dignitati satis. (166) eodem tempore M. Herennius in mediocribus oratoribus Latine et diligenter loquentibus
[164] Eu, então, disse: — Desde menino, aquele discurso contra a lei de Cepião foi para mim como que um mestre, no qual, por um lado, celebra-se o prestígio do senado, ordem em favor da qual se discursava, por outro, incita-se o ódio contra a facção dos juízes e dos acusadores, poder contra o qual era necessário discursar pelo apoio dos populares. Naquele discurso, havia muita dignidade, muita brandura, muita rigidez, muita espirituosidade. Muito mais foi dito do que escrito, o que pode ser deduzido a partir de alguns tópicos apresentados e não desenvolvidos. Aquela mesma censura contra seu companheiro de magistratura não é um discurso, mas como que um sumário dos temas do discurso e um apontamento um pouco mais completo. Nunca, de fato, uma altercação obteve maior aclamação. [165] Na verdade, ele também se sobressaía no discurso popular. O tipo de eloquência de Antônio era mais adequado aos tribunais que às assembleias populares. Nesse contexto não posso omitir o próprio Domício. Com efeito, embora não pertença à categoria dos oradores, todavia considero que nele havia discurso e engenho suficientes para defender não só a figura do magistrado como também a autoridade consular; o mesmo também diria sobre Caio Célio: havia nele excelente zelo e virtudes excelentes, quanto à eloquência, o suficiente aos seus amigos nos assuntos privados e à sua própria dignidade nos assuntos públicos. [166] Na mesma época, Marco Herênio, discursando correta e dili- 
numeratus est; qui tamen summa nobilitate hominem, cognatione sodalitate conlegio, summa etiam eloquentia, L. Philippum in consulatus petitione superauit. eodem tempore C. Claudius etsi propter summam nobilitatem et singularem potentiam magnus erat, tamen etiam eloquentiae quandam mediocritatem adferebat.

(167) eiusdem fere temporis fuit eques Romanus C. Titius, qui meo iudicio eo peruenisse uidetur quo potuit fere Latinus orator sine Graecis litteris et sine multo usu peruenire. huius orationes tantum argutiarum tantum exemplorum tantum urbanitatis habent, ut paene Attico stilo scriptae esse uideantur. easdem argutias in tragoedias satis ille quidem acute sed parum tragice transtulit. quem studebat imitari L. Afranius poeta, homo perargutus, in fabulis quidem etiam, ut scitis, disertus. (168) fuit etiam Q. Rubrius Varro, qui a senatu hostis cum C. Mario iudicatus est, acer et uehemens accusator, in eo genere sane probabilis. doctus autem Graecis litteris propinquus noster, factus ad dicendum, M. Gratidius M. Antoni perfamiliaris, cuius praefectus cum esset in Cilicia est interfectus, qui accusauit C. Fimbriam, M. Mari Gratidiani pater. gentemente, foi elencado entre os oradores medianos. No entanto, superou na disputa do consulado um homem de alta nobreza, relações familiares, associações políticas, colégios sacerdotais e também de grande eloquência: Lúcio Filipo. Na mesma época, Caio Cláudio, ainda que sua grandeza se devesse à sua alta nobreza, tinha adquirido uma eloquência um tanto mediana.

[167] Quase ao mesmo tempo, surgiu um cavaleiro romano, Caio Tício, que a meu ver parece ter alcançado tanto quanto é, em geral, possível para um orador latino alcançar sem as letras gregas e sem muita experiência. Em seus discursos há tanta argúcia, tantos exemplos, tanta urbanidade que parecem ter sido escritos quase à maneira ática. É bem verdade que ele transferiu para as tragédias a mesma perspicácia com bastante agudeza mas com pouca tragicidade. O poeta Lúcio Afrânio, homem de fina perspicácia, em cujas peças também era, conforme você sabe, bem articulado, se empenhava em imitálo. [168] Surgiu também Quinto Rúbrio Varrão, que junto com Caio Mário foi declarado pelo senado inimigo público, um acusador enérgico e veemente, realmente louvável nesse tipo de discurso. Já nosso parente, instruído nas letras gregas, orador nato, muito amigo de Marco Antônio, Marco Gratídio, que foi morto quando era seu prefeito na Cilícia, que acusou Caio Fímbria, era pai de Marco Mário Gratidiano. 
[46] XLVI. (169) Atque etiam apud socios et Latinos oratores habiti sunt Q. Vettius Vettianus e Marsis, quem ipse cognoui, prudens uir et in dicendo breuis; Q. D. Valerii Sorani, uicini et familiares mei, non tam in dicendo admirabiles quam docti et Graecis litteris et Latinis; C. Rusticelius Bononiensis, is quidem et exercitatus et natura uolubilis; omnium autem eloquentissumus extra hanc urbem T. Betutius Barrus Asculanus, cuius sunt aliquot orationes Asculi habitae; illa Romae contra Caepionem nobilis sane, cui orationi Caepionis ore respondit Aelius, qui scriptitauit orationes multis, orator ipse numquam fuit. (170) apud maiores autem nostros uideo disertissimum habitum ex Latio L. Papirium Fregellanum Ti. Gracchi P. f. fere aetate; eius etiam oratio est pro Fregellanis colonisque Latinis habita in senatu. Tum Brutus: quid tu igitur, inquit, tribuis istis externis quasi oratoribus? Quid censes, inquam, nisi idem quod urbanis? praeter unum, quod non est eorum urbanitate quadam quasi colorata oratio. (171) Et Brutus: qui est, inquit, iste tandem urbanitatis color? Nescio, inquam; tantum esse quendam scio. id tu, Brute, iam intelleges, cum in Galliam ueneris; audies tu quidem etiam uerba quaedam non trita Romae, sed haec mutari dediscique possunt; illud est maius, quod in uocibus nos-
[169] E também entre os aliados e os latinos foram considerados oradores Quinto Vítio Vetiano, dos Marsos, que eu conheci pessoalmente, homem prudente e breve ao discursar; Quinto e Décimo Valério de Sora, vizinhos e amigos meus, não eram tão admiráveis na oratória quanto instruídos seja nas letras gregas seja nas latinas; quanto a Caio Rusticélio, de Bonônia, ele não só se exercitava bem mas também possuía uma fluência natural; mas o mais eloquente de todos de fora da cidade foi Tito Betúlio Barro, de Áscolo. Alguns de seus discursos foram pronunciados em Áscolo; aquele em Roma contra Cepião é bem conhecido; a esse discurso Élio, pela boca de Cepião, respondeu, ele que escreveu discursos para muitos, nunca foi ele próprio um orador. [170] Entre nossos antepassados, noto que foi considerado o mais hábil do Lácio Lúcio Papiro de Fregelas, quase contemporâneo de Tibério Graco, filho de Públio; inclusive é considerado dele um discurso no senado em defesa dos fregelanos e dos colonos latinos. Então, Bruto, disse: - Que valor, afinal, você concede a esses oradores, por assim dizer, estrangeiros? - O que acha, respondi, senão o mesmo que aos oradores da cidade? Exceto uma coisa, o fato de que na oratória deles não há, por assim dizer, certo matiz de urbanidade. [171] O que vem a ser, enfim, perguntou Bruto, esse matiz de urbanidade? - Não sei, respondi, só sei que ele existe. O que você logo compreenderá, Bruto, quando chegar à Gália; também ouvirá certas palavras não usuais em Roma, mas elas podem ser 
trorum oratorum retinnit quiddam et resonat urbanius. nec hoc in oratoribus modo apparet, sed etiam in ceteris. (172) ego memini T. Tincam Placentinum hominem facetissimum cum familiari nostro Q. Granio praecone dicacitate certare. Eon', inquit Brutus, de quo multa Lucilius? Isto ipso; sed Tincam non minus multa ridicule dicentem Granius obruebat nescio quo sapore uernaculo; ut ego iam non mirer illud Theophrasto accidisse, quod dicitur, cum percontaretur ex anicula quadam quanti aliquid uenderet et respondisset illa atque addidisset 'hospes, non pote minoris', tulisse eum moleste se non effugere hospitis speciem, quom aetatem ageret Athenis optumeque loqueretur omnium. sic, ut opinor, in nostris est quidam urbanorum sicut illic Atticorum sonus. sed domum redeamus, id est ad nostros reuortamur.

[47] XLVII. (173) Duobus igitur summis Crasso et Antonio L. Philippus proxumus accedebat, sed longo interuallo tamen proxumus. itaque eum, etsi nemo intercedebat qui se illi anteferret, neque secundum tamen neque tertium dixerim. nec enim in quadrigis eum secundum numerauerim aut tertium qui uix e carceribus exierit, cum palmam iam primus acceperit, nec in oratoribus qui tantum absit a primo, uix ut in eo- mudadas e esquecidas; o mais importante é que na pronúncia de nossos oradores vibra e ressoa um tom mais urbano. $\mathrm{E}$ isso se manifesta não só nos oradores como também nos outros cidadãos. [172] Lembro-me de Tito Tinca de Placência, homem espirituosíssimo, que disputava em mordacidade com nosso querido Quinto Grânio, o pregoeiro. - Aquele, preguntou Bruto, de quem Lucílio fala muito? - O próprio; mas Grânio superava Tinca, que dizia coisas não menos espirituosas, com não sei qual aroma vernáculo, que já não me admira o que dizem ter acontecido a Teofrasto que, quando perguntou a uma velha feirante o preço de uma mercadoria, ela teria respondido e acrescentado: "não faço por menos, estrangeiro", ele se aborreceu por não conseguir disfarçar o ar de estrangeiro, embora vivesse em Atenas e falasse de maneira excelente. Desse modo, na minha opinião, há entre nós uma pronúncia peculiar aos oradores urbanos tal como, entre os gregos, aos áticos. Mas retornemos para casa, isto é, voltemos aos nossos.

[173] Então, quem mais se aproximava da excelência de Crasso e Antônio era Lúcio Filipe, mais próximo e, no entanto, a uma grande distância. Por isso, ainda que não houvesse quem o ultrapassasse, no entanto, não o colocaria em segundo nem em terceiro lugar. E, de fato, numa corrida de quadrigas não classificaria em segundo ou em terceiro quem com custo se livrara da cancela, no momento em que o primeiro já alcançara a palma, nem entre os oradores quem tanto se afasta do pri- 
dem curriculo esse uideatur. sed tamen erant ea in Philippo quae, qui sine comparatione illorum spectaret, satis magna diceret: summa libertas in oratione, multae facetiae; satis creber in reperiendis, solutus in explicandis sententiis; erat etiam in primis, ut temporibus illis, Graecis doctrinis institutus, in altercando cum aliquo aculeo et maledicto facetus. (174) horum aetati prope coniunctus L. Gellius non tam uendibilis orator, quam ut nescires quid ei deesset; nec enim erat indoctus nec tardus ad excogitandum nec Romanarum rerum immemor et uerbis solutus satis; sed in magnos oratores inciderat eius aetas; multam tamen operam amicis et utilem praebuit atque ita diu uixit ut multarum aetatum oratoribus implicaretur. (175) multum etiam in causis uersabatur isdem fere temporibus D. Brutus, is qui consul cum Mamerco fuit, homo et Graecis doctus litteris et Latinis. dicebat etiam L. Scipio non imperite Gnaeusque Pompeius Sex. f. aliquem numerum obtinebat. nam Sex. frater eius praestantissimum ingenium contulerat ad summam iuris ciuilis et ad perfectam geometriae rerumque Stoicarum scientiam. itam in iure et ante hos M. Brutus et paulo post eum C. Billienus homo per se magnus prope simili ratione summus euaserat; qui consul factus esset, nisi in Marianos consulatus et in eas petitionis angustias meiro, quase não parecendo fazer a mesma corrida. E, no entanto, havia qualidades em Filipe das quais, sem que se pretenda comparar àqueles, podem-se dizer bastante grandiosas: expressava-se com extrema liberdade, muita espirituosidade; bastante fecundo em encontrar argumentos, fluente ao desenvolvê-los; estava também entre os primeiros do seu tempo no conhecimento das doutrinas gregas; espirituoso no contraditório com algumas alfinetadas e escárnios. [174] Próximo à geração desses esteve Lúcio Gélio, orador não tão digno de recomendação, ainda que não se saiba o que lhe faltava. De fato, não era inculto nem lento no pensamento, nem esquecido dos feitos romanos e bastante fluente nas palavras, mas sua época coincidira com a de grandes oradores; no entanto, trabalhou muito e de modo útil aos seus amigos e viveu tanto que manteve contato com muitas gerações de oradores. [175] Ocupavase também de muitas causas quase nesse mesmo período Décimo Bruto, que foi cônsul com Mamerco, homem instruído tanto nas letras gregas quanto nas latinas. Também não discursava sem habilidade Lúcio Cipião, e Gneu Pompeo, filho de Sexto, possuía certa consideração. Quanto a seu irmão Sexto, aplicou o excepcional engenho ao mais elevado estudo do direito civil e ao completo conhecimento da geometria e do estoicismo. Antes destes Marco Bruto, e logo depois dele Caio Bilieno, homem distinto por seu próprio valor, que quase pela mesma razão, havia ocupado uma posição elevada; que teria se tornado cônsul, se não 
incidisset. (176) Cn. autem Octaui eloquentia, quae fuerat ante consulatum ignorata, in consulatu multis contionibus est uehementer probata. sed ab eis, qui tantum in dicentium numero, non in oratorum fuerunt, iam ad oratores reuortamur. Censeo, inquit Atticus; eloquentis enim uidebare, non sedulos uelle conquirere.

[48] XLVIII. (177) Festiuitate igitur et facetiis, inquam, C. Iulius L. f. et superioribus et aequalibus suis omnibus praestitit oratorque fuit minime ille quidem uehemens, sed nemo unquam urbanitate, nemo lepore, nemo suauitate conditior. sunt eius aliquot orationes, ex quibus sicut ex eiusdem tragoediis lenitas eius sine neruis perspici potest. (178) eius aequalis P. Cethegus, cui de re publica satis suppeditabat oratio - totam enim tenebat eam penitusque cognouerat; itaque in senatu consularium auctoritatem adsequebatur — ; sed in causis publicis nihil, priuatis satis ueterator uidebatur. erat in priuatis causis Q. Lucretius Vispillo et acutus et iuris peritus; nam Afella contionibus aptior quam iudiciis. prudens etiam T. Annius Velina et in eius generis causis orator sane tolerabilis. in eodem genere causarum multum erat $\mathrm{T}$. Iuuentius nimis ille quidem len- tivesse vivido entre os consulados de Mário e as consequentes dificuldades do pleito. [176] Porém a eloquência de Gneu Otávio, que antes do consulado fora desconhecida, durante o consulado foi vivamente apreciada em diversas assembleias populares. Mas deixando esses que pertencem tão somente à categoria dos loquazes não à dos oradores, voltemos agora aos oradores. Concordo, disse Ático. De fato, parece-me que você deseja se empenhar na procura dos eloquentes, não dos diligentes.

[177] - Portanto, continuei, na espitiruosidade e nos gracejos, Caio Júlio, filho de Lúcio, esteve à frente de todos os seus predecessores e contemporâneos, foi um orador de pouco ímpeto, mas jamais houve alguém que na urbanidade, que na graça, que na doçura fosse mais temperado que ele. Existem alguns discursos seus, dos quais tal como de suas tragédias é possível notar sua brandura carente de força. [178] Seu contemporâneo Públio Cetego, cuja capacidade discursiva nos assuntos públicos era suficiente - de fato, dominava-os todos e detinha um profundo conhecimento, por isso alcançou autoridade consular no senado -, mas nas causas penais não tinha muito valor, nas causas privadas aparentava bastante experiência. Era nas causas privadas Quinto Lucrécio Vesilio não só perpicaz mas também perito em direito; Afela, por outro lado, tinha mais aptidão para as assembleias que para os tribunais. Também versado em direito era Tito Ânio de Velina e um orador realmente aceitável nas causas desse gênero. Do mesmo gênero 
tus in dicendo et paene frigidus, sed et callidus et in capiendo aduersario uersutus et praeterea nec indoctus et magna cum iuris ciuilis intellegentia. (179) cuius auditor P. Orbius meus fere aequalis in dicendo non nimis exercitatus, in iure autem ciuili non inferior quam magister fuit. nam $\mathrm{T}$. Aufidius, qui uixit ad summam senectutem, uolebat esse similis horum eratque et bonus uir et innocens, sed dicebat parum; nec sane plus frater eius M. Vergilius, qui tribunus plebis L. Sullae imperatori diem dixit. eius collega P. Magius in dicendo paulo tamen copiosior. (180) sed omnium oratorum siue rabularum, qui et plane indocti et inurbani aut rustici etiam fuerunt, quos quidem ego cognouerim, solutissimum in dicendo et acutissimum iudico nostri ordinis Q. Sertorium, equestris C. Gargonium. fuit etiam facilis et expeditus ad dicendum et uitae splendore multo et ingenio sane probabili T. Iunius L. f. tribunicius, quo accusante P. Sextius praetor designatus damnatus est ambitus; is processisset honoribus longius, nisi semper infirma atque etiam aegra ualetudine fuisset.

[49] XLIX. (181) Atque ego praeclare intellego me in eorum commemoratione uersari qui nec habiti sint oratores neque fuerint, praeteririque a me aliquot ex ueteribus commemo- de causas muito se ocupou Tito Juvêncio, demasiado hesitante e quase apático ao discursar, mas não só hábil como também ardiloso ao encurralar o adversário e, além disso, não era inculto bem como detinha grande conhecimento do direito civil. [179] Seu discípulo Públio Órbio, quase meu contemporâneo, não possuía bastante prática oratória, em direito civil não foi inferior ao mestre. Quanto a Tito Aufídio, que desfrutou de longa velhice, desejava ser semelhante a estes e era um homem não só bom mas também honesto, mas discursava pouco; e mais não o fez seu irmão Marco Vergílio, tribuno da plebe que processou o imperator Sula. Seu colega Públio Mágio, todavia, tinha um discurso um pouco mais copioso. [180] Mas, de todos os oradores, ou melhor, rábulas que eram não apenas bastante incultos como também provincianos ou mesmo rústicos que eu mesmo conheci, creio que o discurso mais fluente e penetrante de nossa ordem é o de Quinto Sertório, da ordem equestre o de Caio Gargônio. Tinha também facilidade e fluência oratória e ao mesmo tempo uma vida gloriosa e um engenho notável Tito Júnio, filho do antigo tribuno Lúcio, cuja acusação condenou o pretor designado Públio Séxtio por fraude eleitoral. Ele teria ido mais longe nas magistraturas, não fosse a saúde sempre fraca e também doente.

[181] E bem me dou conta de que me detenho na menção daqueles que não são considerados oradores nem o teriam sido e de ter omitido entre os antigos alguns dignos de menção ou de elogio. Mas isso 
ratione aut laude dignos. sed hoc quidem ignoratione; quid enim est superioris aetatis quod scribi possit de iis, de quibus nulla monumenta loquuntur nec aliorum nec ipsorum? de his autem quos ipsi uidimus neminem fere praetermittimus eorum quos aliquando dicentis audiuimus. (182) uolo enim sciri in tanta et tam uetere re publica maxumis praemiis eloquentiae propositis omnes cupisse dicere, non plurumos ausos esse, potuisse paucos. ego tamen ita de uno quoque dicam, ut intellegi possit quem existimem clamatorem, quem oratorem fuisse. isdem fere temporibus aetate inferiores paulo quam Iulius sed aequales propemodum fuerunt C. Cotta P. Sulpicius Q. Varius Cn. Pomponius C. Curio L. Fufius M. Drusus P. Antistius; nec ulla aetate uberior oratorum fetus fuit. (183) ex his Cotta et Sulpicius cum meo iudicio tum omnium facile primas tulerunt. Hic Atticus: quo modo istuc dicis, inquit, cum tuo iudicio tum omnium? semperne in oratore probando aut improbando uolgi iudicium cum intellegentium iudicio congruit? an alii probantur multitudine, alii autem ab iis qui intellegunt? Recte requiris, inquam, Attice; sed audies ex me fortasse quod non omnes probent. (184) An tu, inquit, id laboras, si huic modo Bruto probaturus es? Plane, inquam, Attice, disputationem hanc de oratore ocorre por ignorância; o que é que pode ser escrito sobre aqueles de uma época passada sobre os quais nada dizem os registros escritos nem por outros nem por eles mesmos? Sobre esses, porém, que eu mesmo vi, não deixei de mencionar ninguém que ouvi discursar outrora. [182] Com efeito, quero que se saiba que em tão grande e tão antiga república, sendo oferecidas as mais altas recompensas à eloquência, todos desejavam discursar em público, não muitos ousaram fazê-lo, puderam fazê-lo poucos. Eu, no entanto, discorrerei sobre cada um de modo que se possa compreender quem eu considero que foi um berrador, quem um orador. Quase no mesmo período, um pouco mais jovens que Júlio, mas quase contemporâneos, surgiram Caio Cota, Públio Sulpício, Quinto Vário, Gneu Pompônio, Caio Cúrio, Lúcio Fúfio, Mário Druso, Públio Antístio, e em nenhuma época houve safra de oradores mais fértil. [183] Destes, Cota e Sulpício alcançaram facilmente o primeiro lugar não só na minha opinião como também na de todos. Então, Ático perguntou: - O que você quer dizer com não só na minha como também na de todos? Acaso ao aprovar ou reprovar um orador sempre a opinião do vulgo coincide com a opinião dos entendidos no assunto? Ou alguns são aprovados pela multidão, enquanto outros o são por aqueles que entendem do assunto? - Sua questão, Ático, é pertinente, respondi. Mas você vai ouvir de mim algo que talvez nem todos concordem. [184] — Por acaso você se preocupa, perguntou, se for elogiado somente por 
probando aut improbando multo malim tibi et Bruto placere, eloquentiam autem meam populo probari uelim. et enim necesse est, qui ita dicat ut a multitudine probetur, eundem doctis probari. nam quid in dicendo rectum sit aut prauum ego iudicabo, si modo is sum qui id possim aut sciam iudicare; qualis uero sit orator ex eo, quod is dicendo efficiet, poterit intellegi. (185) tria sunt enim, ut quidem ego sentio, quae sint efficienda dicendo: ut doceatur is apud quem dicetur, ut delectetur, ut moueatur uehementius. quibus uirtutibus oratoris horum quidque efficiatur aut quibus uitiis orator aut non adsequatur haec aut etiam in his labatur et cadat, artifex aliquis iudicabit. efficiatur autem ab oratore necne, ut ii qui audiunt ita afficiantur ut orator uelit, uolgi adsensu et populari adprobatione iudicari solet. itaque numquam de bono oratore aut non bono doctis hominibus cum populo dissensio fuit.

[50] L. (186) an censes, dum illi uiguerunt quos ante dixi, non eosdem gradus oratorum uulgi iudicio et doctorum fuisse? de populo si quem ita rogauisses: quis est in hac ciuitate eloquentissimus? in Anto-
Bruto? - É claro, Ático, que nessa discussão, respondi, obter a tua aprovação e a de Bruto acerca do que se deve elogiar ou censurar num orador bem que eu preferiria, porém gostaria que minha eloquência fosse elogiada pelo povo. E, de fato, é necessário que quem discursa de tal modo que seja elogiado pela multidão, também seja elogiado pelos conhecedores do assunto. Com efeito, farei meu julgamento sobre o que seja correto ou vicioso no discurso, se é que eu sou alguém que tem a capacidade e o conhecimento para julgá-lo, mas o valor do orador poderá ser percebido pela eficácia de seu discurso. [185] Com efeito, são três, a meu ver, os efeitos que um discurso deve produzir: que seja instruído aquele para quem se fala, que seja lisonjeado, que seja veementemente comovido. Por quais virtudes oratórias se obtém cada um desses efeitos, ou por quais vícios o orador ou não os alcança, ou mesmo em qual deles ele vacila e cai, é algo que um perito na arte julgará. Mas se o efeito é ou não produzido pelo orador, se os ouvintes sentem as emoções que o orador deseja, isso costuma ser julgado pelo assentimento do vulgo e pela aprovação popular. Por isso nunca ouve dissenso entre os homens cultos e o povo sobre quem era bom orador e quem não era bom.

[186] Acaso pensas que quando floresceram aqueles de que falei antes não era a mesma a hierarquia dos oradores na opinião do vulgo e dos cultos. Se fizesses uma pergunta a alguém do povo: quem é o homem mais eloquente dessa cidade? Entre 
nio et Crasso aut dubitaret aut hunc alius, illum alius diceret. nemone Philippum, tam suauem oratorem tam grauem tam facetum his anteferret, quem nosmet ipsi, qui haec arte aliqua uolumus expendere, proximum illis fuisse diximus? nemo profecto; id enim ipsum est summi oratoris summum oratorem populo uideri. (187) quare tibicen Antigenidas dixerit discipulo sane frigenti ad populum: 'mihi cane et Musis'; ego huic Bruto dicenti, ut solet, apud multitudinem: 'mihi cane et populo, mi Brute', dixerim, ut qui audient quid efficiatur, ego etiam cur id efficiatur intellegam. credit eis quae dicuntur qui audit oratorem, uera putat, adsentitur probat, fidem facit oratio: (188) tu artifex quid quaeris amplius? delectatur audiens multitudo et ducitur oratione et quasi uoluptate quadam perfunditur: quid habes quod disputes? gaudet dolet, ridet plorat, fauet odit, contemnit inuidet, ad misericordiam inducitur ad pudendum ad pigendum; irascitur miratur sperat timet; haec perinde accidunt ut eorum qui adsunt mentes uerbis et sententiis et actione tractantur; quid est quod exspectetur docti alicuius sententia? quod enim probat multitudo, hoc idem doctis probandum est. denique hoc specimen est popularis iudici, in quo numquam fuit populo cum doctis intellegentibusque dissensio. (189)
Antônio e Crasso, ou bem hesitaria ou bem alguém diria esse, outra pessoa, aquele. Porventura alguém a estes anteporia Filipe, tão agradável orador, tão sério, tão espirituoso, alguém que eu, pretendendo examinar o assunto a partir de certos critérios técnicos, coloquei próximo deles? Seguramente ninguém. De fato, o que é próprio de um orador excelente é parecer ao povo um orador excelente. [187] Por essa razão o flautista Antigenidas teria dito a um discípulo, recebido com bastante frieza pelo público: "canta para mim e para as Musas"; eu, por outro lado, teria dito a Bruto que discursava diante da multidão como de costume: "canta para mim e para o povo, caro Bruto", de modo que os ouvintes percebam a eficácia do discurso, enquanto eu compreenderei o porquê desse efeito. Quem ouve um orador crê no que é dito, julga ser verdadeiro, assente, aprova, o discurso produz convencimento: [188] Tu, perito na arte, que queres mais? Agrada-se a multidão ouvinte e é conduzida pelo discurso e é como que inundada numa espécie de prazer: que tens para contestar? Alegra-se e lamenta, ri e chora, ama e odeia, despreza e inveja, é induzida à comiseração, à vergonha, ao pesar; ira-se e admira-se, espera e teme, isto ocorre na medida em que as mentes dos ouvintes são manejadas pelas palavras, pelos pensamentos e pela atuação; por que razão se deve buscar a opinião de algum erudito? Com efeito, aquilo que a multidão louva também deve ser louvado pelos eruditos. Numa palavra, o indício da qualidade da opinião popular é que nunca houve 
cum multi essent oratores in uario genere dicendi, quis umquam ex his excellere iudicatus est uolgi iudicio, qui non idem a doctis probaretur? quando autem dubium fuisset apud patres nostros eligendi cui patroni daretur optio, quin aut Antonium optaret aut Crassum? aderant multi alii; tamen utrum de his potius dubitasset aliquis, quin alterum nemo. quid? adulescentibus nobis cum esset Cotta et Hortensius, num quis, quoi quidem eligendi potestas esset, quemquam his anteponebat?

[51] LI. (190) Tum Brutus: quid $\mathrm{tu}$, inquit, quaeris alios? de te ipso nonne quid optarent rei, quid ipse Hortensius iudicaret uidebamus? qui cum partiretur tecum causas - saepe enim interfui - perorandi locum, ubi plurimum pollet oratio, semper tibi relinquebat. Faciebat ille quidem, inquam, et mihi beneuolentia, credo, ductus tribuebat omnia. sed ego quae de me populi sit opinio nescio; de reliquis hoc adfirmo, qui uolgi opinione disertissimi habiti sint, eosdem intellegentium quoque iudicio fuisse probatissimos. (191) nec enim posset idem Demosthenes dicere, quod dixisse Antimachum clarum poetam ferunt: qui cum conuocatis auditoribus legeret eis magnum illud, quod nouistis, uolumen suum et eum legentem omnes praeter divergência entre a opinião do povo e a dos eruditos e conhecedores do assunto. [189] Embora haja muitos oradores no variegado gênero oratório, quem entre eles alguma vez foi considerado excelente pela opinião do vulgo, que não tenha sido louvado pelos eruditos? Na época dos nossos pais, porém, quando havia opção de escolher o patrono, quem não teria escolhido ou Antônio ou Crasso? Muitos outros acorriam, e, embora houvesse quem hesitasse entre ambos, ninguém escolheria uma terceira opção. Ora, na minha juventude quando havia Cota e Hortênsio, por acaso alguém a quem fosse dado o poder de escolher perferiria alguém a eles?

[190] Bruto, então, perguntou: — Por que você procura outros exemplos? Por ventura, a respeito de você, não sabíamos qual era o desejo dos réus, qual era a opinião do próprio Hortênsio? Ele que quando dividia as causas com você - de fato, presenciei algumas vezes - sempre lhe deixava a peroração, onde o discurso tem mais força. - Ele fazia isso realmente, continuei, e conduzido pela benevolência, acredito, atribuía a mim todos os méritos. Mas, de minha parte, desconheço qual seja a opinião do povo a meu respeito, afirmo a respeito dos outros o seguinte: aqueles que são considerados mais eloquentes na opinião do vulgo também eram, do ponto de vista dos conhecedores do assunto, os mais elogiados. [191] E, de fato, Demóstenes não poderia ter dito aquilo que se conta que o ilustre poeta Antímaco disse: tendo convidado um auditório, começou 
Platonem reliquissent, 'legam' inquit 'nihilo minus: Plato enim mihi unus instar est centum milium'. et recte: poema enim reconditum paucorum adprobationem, oratio popularis adsensum uolgi debet mouere. at si eundem hunc Platonem unum auditorem haberet Demosthenes, cum esset relictus a ceteris, uerbum facere non posset. (192) quid tu, Brute? possesne, si te ut Curionem quondam contio reliquisset? Ego uero, inquit ille, ut me tibi indicem, in eis etiam causis, in quibus omnis res nobis cum iudicibus est, non cum populo, tamen si a corona relictus sim, non queam dicere. Ita se, inquam, res habet. ut, si tibiae inflatae non referant sonum, abiciendas eas sibi tibicen putet, sic oratori populi aures tamquam tibiae sunt; eae si inflatum non recipiunt aut si auditor omnino tamquam equus non facit, agitandi finis faciendus est.

[52] LII. (193) hoc tamen interest, quod uolgus interdum non probandum oratorem probat, sed probat sine comparatione; cum a mediocri aut etiam malo delectatur, eo est contentus; esse melius non sentit, illud quod est qualecumque est probat. tenet enim aures uel mediocris orator, sit modo aliquid in eo; a ler para eles aquele seu grande volume, que vós conheceis, e, enquanto lia, todos o abandonaram exceto Platão, "lerei mesmo assim", ele disse, "para mim, realmente, Platão sozinho vale por cem mil". E estava certo: é que um poema sofisticado deve suscitar a aprovação de poucos, um discurso popular o assentimento do vulgo. Por outro lado, se Demóstenes tivesse como único ouvinte este mesmo Platão, depois de ter sido abandonado pelos outros, não seria capaz de pronunciar uma palavra. [192] E você, Bruto? Acaso seria capaz, se a assembleia lhe abandonasse como no caso de Curião? - Na verdade, ele disse, eu lhe confesso que mesmo naquelas causas em que todo nosso trabalho se concentra nos juízes, e não no povo, ainda assim, se eu for abandonado pelo público, não serei capaz de discursar. - É o que acontece, continuei. Tal como um flautista que, se tivesse assoprado algumas flautas que não produziam som, pensa em se livrar delas, assim também os ouvidos do povo são como que flautas para o orador, se elas não recebem o sopro ou se o auditório como um todo é, por assim dizer, um cavalo bravio, convém terminar com os esforços.

[193] No entanto, há uma diferença: é que o vulgo aprova um orador que não deve ser aprovado, mas aprova sem compará-lo; quando um orador medíocre ou mesmo ruim o agrada, contenta-se com isso; não percebe que existem melhores, aprova qualquer coisa que lhe seja dito. É que mesmo o orador mediano captura os ouvidos, contanto que possua alguma qualidade; e nada 
nec res ulla plus apud animos hominum quam ordo et ornatus ualet. (194) Quare quis ex populo, cum Q. Scaeuolam pro M. Coponio dicentem audiret in ea causa de qua ante dixi, quicquam politius aut elegantius aut omnino melius aut exspectaret aut posse fieri putaret? (195) cum is hoc probare uellet, $\mathrm{M}$. Curium, cum ita heres institutus esset, 'si pupillus ante mortuus esset quam in suam tutelam uenisset', pupillo non nato heredem esse non posse: quid ille non dixit de testamentorum iure, de antiquis formulis? quem ad modum scribi oportuisset, si etiam filio non nato heres institueretur? (196) quam captiosum esse populo quod scriptum esset neglegi et opinione quaeri uoluntates et interpretatione disertorum scripta simplicium hominum peruertere?

(197) quam ille multa de auctoritate patris sui, qui semper ius illud esse defenderat? quam omnino multa de conseruando iure ciuili? quae quidem omnia cum perite et scienter, item breuiter et presse et satis ornate et pereleganter diceret, quis esset in populo, qui aut exspectaret aut fieri posse quicquam melius putaret? [53] LIII. At uero, ut contra Crassus ab adulescente delicato, qui in litore ambulans scalmum repperisset ob eamque rem aedificare nauem concupiuisset, exorsus est, similiter Scaeuolam ex uno tem mais força no ânimo dos homens do que a ordem e o ornato. [194] Por essa razão, quem do povo, quando ouvia Quinto Cévola discurssando em favor de Marco Copônio na causa sobre a qual falei antes, esperava ou pensava que pudesse haver algo mais refinado ou mais elegante ou melhor em geral? [195] Ele pretendia provar o seguinte, Mânio Cúrio teria sido instituído herdeiro, se o pupilo tivesse morrido antes de ter se tornado maior, não tendo nascido o pupilo, não poderia se tornar herdeiro: o que ele não disse sobre o direito testamentário, sobre as antigas fórmulas? De que modo deveria ter escrito para que fosse instituído herdeiro mesmo que não tivesse nascido o filho? [196] Quão capcioso seria ao povo o fato de o texto ter sido ignorado, e as intenções serem procuradas por conjecturas, e serem distorcidos os textos de homens simples por meio da interpretação de habilidosos?

[197] Quantas coisas ele disse acerca da autoridade de seu pai, que sempre defendera a legalidade desses documentos? Quantas coisas, sobre a necessidade de se conservar o direito civil? E falava tudo isso com perícia e sabedoria mas também com brevidade e precisão, e de modo ornado e elegante, quem do povo, que esperaría ou pensaría que alguém pudesse fazê-lo melhor? Mas, quando Crasso, na parte contrária, iniciou seu discurso falando de um jovem melindroso, que andando pela praia encontrara uma cavilha de remos e por isso desejara construir uma embarcação, do mesmo modo que Cévola, a partir 
scalmo captionis centumuirale iudicium hereditatis effecisse: hoc in illo initio consecutus, multis eiusdem generis sententiis delectauit animosque omnium qui aderant in hilaritatem a seueritate traduxit; quod est unum ex tribus quae dixi ab oratore effici debere. deinde hoc uoluisse eum qui testamentum fecisset, hoc sensisse, quoquo modo filius non esset qui in suam tutelam ueniret, siue non natus siue ante mortuus, Curius heres ut esset; ita scribere plerosque et id ualere et ualuisse semper. haec et multa eius modi dicens fidem faciebat; quod est ex tribus oratoris officiis alterum. (198) deinde aequum bonum, testamentorum sententias uoluntatesque tutatus est: quanta esset in uerbis captio cum in ceteris rebus tum in testamentis, si neglegerentur uoluntates; quantam sibi potentiam Scaeuola adsumeret, si nemo auderet testamentum facere postea nisi de illius sententia. haec cum grauiter tum ab exemplis copiose, tum uarie, tum etiam ridicule et facete explicans eam admirationem adsensionemque commouit, dixisse ut contra nemo uidereur. hoc erat oratoris officium partitione tertium, genere maxumum. hic ille de populo iudex, qui separatim alterum admiratus esset, idem audito altero iudicium suum contemneret; at uero intellegens et doctus audiens Scaeuolam sentiret esse quoddam uberius de uma única cavilha de truque, instaurou no tribunal dos centúnviros um processo de herança: tendo feito isso no início do discurso, com muitos argumentos desse tipo agradou e conduziu o ânimo de todos os presentes da seriedade ao bom humor, e esse é um dos três efeitos que o orador, como eu disse, deve produzir. Depois, sustentou que quem havia escrito o testamento queria dizer o seguinte: mesmo que não existisse o filho que viria para sua tutela, seja porque não nasceu, seja porque morreu antes, Cota seria seu herdeiro; assim a maioria escrevia e isso era válido e sempre fora válido. Discursando do mesmo modo sobre essas coisas e muitas outras incutia confiança, que é o terceiro dos três ofícios do orador. [198] Em seguida, tutelou a boa equidade, os sentidos e os propósitos dos testamentos: quanto truque haveria nas palavras, não só nas demais coisas mas sobretudo nos testamentos, se fossem ignorados seus significados, quanto poder Cévola tomou para si, se ninguém depois disso ousava fazer um testamento sem o aval dele. Desenvolvendo isso não apenas com dignidade mas também com abundância de exemplos, com variedade, e também com humor e espirituosidade, suscitou a admiração e o consenso, de tal modo que parecia que ninguém havia discursado do lado contrário. Este era, nessa divisão, o terceiro ofício do orador, o gênero mais importante. Aqui, aquele juíz do povo que separadamente tivesse admirado o primeiro, tendo ouvido o segundo mudaria seu próprio juízo, mas, por outro 
dicendi genus et ornatius. ab utroque autem causa perorata, si quaereretur uter praestaret orator, numquam profecto sapientis iudicium a iudicio uolgi discreparet.

[54] LIV. (199) Qui praestat igitur intellegens imperito? magna re et difficili; si quidem magnum est scire quibus rebus efficiatur amittaturue dicendo illud quicquid est, quod aut effici dicendo oportet aut amitti non oportet. praestat etiam illo doctus auditor indocto, quod saepe, cum oratores duo aut plures populi iudicio probantur, quod dicendi genus optumum sit intellegit. nam illud quod populo non probatur, ne intellegenti quidem auditori probari potest. ut enim ex neruorum sono in fidibus quam scienter ei pulsi sint intellegi solet, sic ex animorum motu cernitur quid tractandis his perficiat orator. (200) itaque intellegens dicendi existumator non adsidens et adtente audiens sed uno aspectu et praeteriens de oratore saepe iudicat. uidet oscitantem iudicem, loquentem cum altero, non numquam etiam circulantem, mittentem ad horas, quaesitorem ut dimittat rogantem: intellegit oratorem in ea causa non adesse qui possit animis iudicum admouere orationem tamquam fidibus manum. idem si praeteriens aspexerit erectos lado, o conhecedor e o douto ouvindo Cévola perceberiam qua havia outro gênero oratório mais abundante e mais ornado. Tendo ambos, porém, concluído o discurso, se perguntássemos qual dos dois é melhor orador, certamente jamais haveria discrepância entre a opinião do sábio e a opinião do vulgo.

[199] Em que, portanto, o conhecedor é melhor que o não especialista? Em algo grande e difícil, se é que é grande saber com que meios do discurso se efetua ou se deixa escapar o que quer que seja, aquilo que no discurso ou convém que se efetue ou não convém que se deixe escapar. Também é preferível o ouvinte culto ao inculto porque muitas vezes, quando dois ou mais oradores são aprovados pela opinião popular, ele sabe qual é o melhor gênero oratório. De fato, aquilo que não é aprovado pelo povo tampouco pode ser aprovado pelo auditório inteligente. É que assim como pelo som das cordas da lira costuma se saber quão sabiamente elas são tocadas, pelo movimento dos ânimos se percebe a capacidade do orador em manejá-los. [200] Por isso, o crítico especialista em oratória sem assistir e ouvir atentamente mas muitas vezes numa única visada e de passagem julga o orador. Ele vê o juiz bocejando, falando com o outro, às vezes também formando círculo, procurando saber as horas, pedindo ao presidente que suspenda a sessão. Entende que naquela causa não está presente um orador que seja capaz de mover os ânimos dos juízes com o discurso tal como a cítara com as mãos. Igualmente, 
intuentis iudices, ut aut doceri de re idque etiam uoltu probare uideantur, aut ut auem cantu aliquo sic illos uiderit oratione quasi suspensos teneri aut, id quod maxume opus est, misericordia odio motu animi aliquo perturbatos esse uehementius: ea si praeteriens, ut dixi, aspexerit, si nihil audiuerit, tamen oratorem uersari in illo iudicio et opus oratorium fieri aut perfectum iam esse profecto intelleget.

[55] LV. (201) Cum haec disseruissem, uterque adsensus est; et ego tamquam de integro ordiens: quando igitur, inquam, a Cotta et Sulpicio haec omnis fluxit oratio, cum hos maxume iudicio illorum hominum et illius aetatis dixissem probatos, reuortar ad eos ipsos; tum reliquos, ut institui, deinceps persequar. quoniam ergo oratorum bonorum - hos enim quaerimus - duo genera sunt, unum attenuate presseque, alterum sublate ampleque dicentium, etsi id melius est quod splendidius et magnificentius, tamen in bonis omnia quae summa sunt iure laudantur. (202) sed cauenda est presso illi oratori inopia et ieiunitas, amplo autem inflatum et corruptum orationis genus. inueniebat igitur acute Cotta, dicebat pure ac solute; et ut ad infirmi- se de passagem tivesse notado que os juízes observam com atenção, de modo que eles ou pareciam serem instruídos sobre o fato e também mostravam aprovação nos semblantes, ou tal como uma ave levada por um canto assim também os teria visto como que suspensos pelo discurso, ou, o que é mais importante, que pela misericórdia, pelo ódio, por algum movimento do ânimo, são comovidos com muita força; se, como eu disse, de passagem, tivesse prestado atenção nisso, se nada tivesse ouvido, contudo certamente compreenderá que nesse processo se trata de um orador e que a obra oratória está se fazendo ou já foi concluída.

[201]Como eu fizesse esse raciocínio, ambos consentiram; eu, então, como que começando de novo, disse: - Então, já que todo esse discurso fluiu de Cota e Sulpício, no momento em que dizia serem eles muito bem aprovados na opinião daqueles homens e naquele tempo, retornaremos a eles; então, como estabeleci, examinarei os restantes. Portanto, uma vez que há dois tipos de bons oradores - e são esses que procuramos -, o primeiro discurso, plano e conciso, o outro, elevado e copioso, embora seja o melhor aquele que é mais brilhante e mais rico; no entanto, com razão é louvado nos bons tudo aquilo que atinge a perfeição. [202] Mas há que se precaver o orador conciso da pobreza e da aridez, o copioso, porém, do gênero oratório inflado e corrupto. Cota, pois, encontrava os argumentos com agudeza, discursava com pureza e desenvoltura, e renunciava 
tatem laterum perscienter contentionem omnem remiserat, sic ad uirium imbecillitatem dicendi accommodabat genus. nihil erat in eius oratione nisi sincerum, nihil nisi siccum atque sanum; illudque maxumum quod, cum contentione orationis flectere animos iudicum uix posset nec omnino eo genere diceret, tractando tamen impellebat, ut idem facerent a se commoti quod a Sulpicio concitati. (203) fuit enim Sulpicius omnium uel maxume, quos quidem ego audiuerim, grandis et, ut ita dicam, tragicus orator. uox cum magna tum suauis et splendida; gestus et motus corporis ita uenustus, ut tamen ad forum, non ad scaenam institutus uideretur; incitata et uolubilis nec ea redundans tamen nec circumfluens oratio. Crassum hic uolebat imitari; Cotta malebat Antonium; sed ab hoc uis aberat Antoni, Crassi ab illo lepos. (204) O magnam, inquit, artem, Brutus: si quidem istis, cum summi essent oratores, duae res maxumae altera alteri defuit. [56] LVI. Atque in his oratoribus illud animaduertendum est, posse esse summos qui inter se sint dissimiles. nihil enim tam dissimile quam Cotta Sulpicio, et uterque aequalibus suis plurimum praestitit. quare hoc doctoris intellegentis est uidere, quo ferat natura sua quemque, et ea duce utentem sic instituere, ut Isocratem in acerrimo ingenio Theopompi et lenissimo muito sabiamente a todo esforço dos pulmões, de modo que acomodava seu gênero oratório à fraqueza de suas forças. Em seu discurso, não havia nada além de pureza, nada além de aridez e sobriedade; e o mais notável era que, embora com custo fosse capaz de mover os ânimos dos juízes pela tensão do discurso e não utilizasse geralmente esse gênero oratório, ao manejá-los, contudo, induzia-os a fazerem, conduzindoos, o mesmo que Sulpício, inflamando-os. [203] É que Sulpício, entre todos que eu mesmo ouvi, foi o mais grandioso possível e, por assim dizer, o mais trágico. A voz não só robusta como também harmoniosa e límpida, o gesto e o movimento do corpo tão elegantes mas que apesar disso pareciam formados para o fórum, não para o drama; um discurso intenso e fluente e, apesar disso, não redundante nem transbordante. Ele queria imitar Crasso, Cota preferia Antônio, mas neste faltava o vigor de Antônio, naquele a graça de Crasso. [204] - Ó grandiosa arte, disse Bruto, se é verdade que estes, que foram oradores excelentes, das duas coisas mais importantes cada um carecia de uma. E nesses oradores há que se notar o seguinte, é possível que sejam excelentes os que são diferentes entre si. De fato, nada é tão diferente quanto Cota e Sulpício, e ambos superam em muito seus contemporâneos. Por isso é próprio do mestre inteligente ver para onde a natureza de cada um o conduz e, utilizando-a como guia, formá-lo dessa maneira, tal como se conta que Isócrates frente ao engenho de Teopompo e à 
Ephori dixisse traditum est, alteri se calcaria adhibere alteri frenos. (205) Sulpici orationes quae feruntur, eas post mortem eius scripsisse P. Cannutius putatur aequalis meus, homo extra nostrum ordinem meo iudicio disertissimus. ipsius Sulpici nulla oratio est, saepeque ex eo audiui, cum se scribere neque consuesse neque posse diceret. Cottae pro se lege Varia quae inscribitur, eam L. Aelius scripsit Cottae rogatu. fuit is omnino uir egregius et eques Romanus cum primis honestus idemque eruditissimus et Graecis litteris et Latinis, antiquitatisque nostrae et in inuentis rebus et in actis scriptorumque ueterum litterate peritus. quam scientiam Varro noster acceptam ab illo auctamque per sese, uir ingenio praestans omnique doctrina, pluribus et inlustrioribus litteris explicauit.

(206) sed idem Aelius Stoicus esse uoluit, orator autem nec studuit unquam nec fuit. scribebat tamen orationes, quas alii dicerent; ut Q. Metello f., ut Q. Caepioni, ut Q. Pompeio Rufo; quamquam is etiam ipse scripsit eas quibus pro se est usus, sed non sine Aelio. (207) his enim scriptis etiam ipse interfui, cum essem apud Aelium adulescens eumque audire perstudiose solerem. Cottam autem miror summum ipsum ora- brandura de Éforo dissera que num ele colocava esporos, noutro freios. [205] Circulam alguns discursos de Sulpício, que foram escritos depois de sua morte provavelmente por Públio Canútio, meu contemporâneo, a meu ver, o homem mais eloquente fora da nossa ordem [senatorial]. Não há nenhum discurso do próprio Sulpício, e muitas vezes o ouvi quando dizia que ele não costumava nem era capaz de escrever. O discurso de Cota que se intitula autodefesa com base na lei Vária foi escrito, a pedido de Cota, por Lúcio Élio. Este que foi um homem absolutamente distinto e um cavaleiro romano dos mais honrados e também muito erudito tanto nas letras gregas como nas latinas, na história não só das nossas intituições mas também de nossos feitos, bem como nos escritores antigos, perito cultivado. Conhecimento que nosso amigo Varrão, tendo recebido daquele e aguçado por si mesmo, homem superior pelo engenho e pela completa instrução, desenvolveu em maior número e em mais célebres escritos.

[206] Mas, voltando a Élio, professou ser estóico, mas nunca se empenhou como orador nem o foi. No entanto, escrevia discursos, os quais outros pronunciavam, como Quinto Metelo, filho de Quinto, como Quinto Cepião, como Quinto Pompeio Rufo, se bem que este último também ele próprio escreveu o discurso que usou em sua autodefesa, mas não sem a ajuda de Élio. [207] É que no momento de sua escrita eu mesmo estava presente, quando na casa de Élio, na minha juventude, eu costu- 
torem minimeque ineptum Aelianas leues oratiunculas uoluisse existimari suas. [57] LVII. His duobus eiusdem aetatis adnumerabatur nemo tertius, sed mihi placebat Pomponius maxime uel dicam minime displicebat. locus erat omnino in maxumis causis praeter eos de quibus supra dixi nemini; propterea quod Antonius, qui maxume expetebatur, facilis in causis recipiendis erat; fastidiosior Crassus, sed tamen recipiebat. horum qui neutrum habebat, confugiebat ad Philippum fere aut ad Caesarem; Cotta tum et Sulpicius expetebantur. ita ab his sex patronis causae inlustres agebantur; neque tam multa quam nostra aetate iudicia fiebant, neque hoc quod nunc fit, ut causae singulae defenderentur a pluribus, quo nihil est uitiosius. (208) respondemus iis quos non audiuimus: in quo primum saepe aliter est dictum aliter ad nos relatum; deinde magni interest coram uidere me quem ad modum aduersarius de quaque re adseueret, maxime autem quem ad modum quaeque res audiatur. sed nihil uitiosius quam, cum unum corpus debeat esse defensionis, nasci de integro causam, cum sit ab altero perorata. (209) omnium enim causarum unum est naturale principium, una peroratio; reliquae partes quasi membra suo quaeque loco locata suam et uim et dignitatem tenent. cum autem difficile mava ouvi-lo com muita atenção. Admirame que Cota, ele próprio orador excelente e nada inepto, quisesse que os pequenos discursinhos fossem considerados seus. A esses dois ninguém do mesmo período se acrescentava como terceiro, mas me agradava mais Pompônio, ou então diria, desagradava menos. Absolutamente ninguém tinha lugar nas causas mais importantes além daqueles de que falei antes, porque Antônio, que era extremamente requisitado, era obsequioso em aceitar as causas; Crasso, mais desdenhoso, contudo, aceitava. Quem não tinha nenhum dos dois recorria quase sempre a Filipo ou a César, depois eram requisitados Cota e Sulpício. Assim, eram esses seis patronos que atuavam nas causas mais célebres, e não havia tantos processos quanto em nossa época nem o que acontece hoje, em que uma única causa é defendida por muitos, nada é mais vicioso que isso. [208] Respondemos àqueles que não ouvimos, nisso sucede que, em primeiro lugar, muitas vezes algo é dito de um modo e nos é relatado de outro, em segundo, é de grande importância que eu veja pessoalmente de que maneira o adversário sustenta cada argumento, mas principalmente de que maneira cada argumento é recebido. Mas, como a defesa deve ser um corpo único, nada pior do que a causa ter de nascer novamente a cada vez que um outro faz sua peroração. [209] É que todas as causas têm um único princípio, uma única peroração, as demais partes, por assim dizer, sendo dispostas cada uma no seu lugar obtêm valor e eficácia. Po- 
sit in longa oratione non aliquando aliquid ita dicere, ut sibi ipse non conueniat, quanto difficilius cauere, ne quid dicas, quod non conueniat eius orationi qui ante te dixerit. sed quia et labor multo maior est totam causam quam partem dicere et quia plures ineuntur gratiae, si uno tempore dicas pro pluribus, idcirco hanc consuetudinem lubenter adsciuimus.

[58] LVIII. (210) Erant tamen, quibus uideretur illius aetatis tertius Curio, quia splendidioribus fortasse uerbis utebatur et quia Latine non pessume loquebatur usu credo aliquo domestico. nam litterarum admodum nihil sciebat; sed magni interest quos quisque audiat cotidie domi, quibuscum loquatur a puero, quem ad modum patres paedagogi matres etiam loquantur. (211) legimus epistulas Corneliae matris Gracchorum: apparet filios non tam in gremio educatos quam in sermone matris. auditus est nobis Laeliae C. f. saepe sermo: ergo illam patris elegantia tinctam uidimus et filias eius Mucias ambas. quarum sermo mihi fuit notus, et neptes Licinias, quas nos quidem ambas, hanc uero Scipionis etiam tu, Brute, credo, aliquando audisti loquentem. Ego uero ac lubenter quidem, inquit Brutus; et eo lubentius, quod L. Crassi erat filia. (212) Quid Crassum, inquam, rém, como em um longo discurso é difícil se precaver de às vezes dizer algo que não seja conveniente a si próprio, é ainda mais difícil cuidar para que não digas nada que não seja conveniente ao discurso de quem discursou antes de ti. E não só porque é bem mais trabalhoso sustentar inteiramente uma causa do que apenas uma parte dela mas também porque obtêm-se assim mais favores, se a um só tempo discursas em defesa de muitos, por isso adotamos de bom grado esse costume.

[210] Havia, no entanto, quem considerasse que nessa época Cúrio seria o terceiro, talvez porque empregasse palavras de maior brilho e porque seu latim não era muito ruim, creio que em razão de um costume familiar. Com efeito, não era nenhum pouco letrado, mas é grande a importância aqueles que ouvimos diariamente em casa, aqueles com quem falamos desde a infância, de que modo falam nossos pais, os preceptores e até mesmo as mães. [211] Pude ler as cartas de Cornélia, mãe dos Graco: nota-se que seus filhos foram nutridos não tanto no seio quanto na linguagem materna. Eu mesmo ouvi Lélia muitas vezes, filha de Caio, e sua fala, então, me parecia tingida da elegância do pai, assim como a das suas duas filhas com Múcio. Conheci bem o modo de falar delas e também ouvi as duas netas, filhas de Licínio, mas aquela que se casou com Cipião, Bruto, creio que você a ouviu conversando alguma vez. - Sim, é verdade, e de bom grado, Bruto respondeu, e ainda mais porque era filha de Lúcio 
illum censes istius Liciniae filium, Crassi testamento qui fuit adoptatus? Summo iste quidem dicitur ingenio fuisse, inquit; et uero hic Scipio conlega meus mihi sane bene et loqui uidetur et dicere. Recte, inquam, iudicas, Brute. etenim istius genus est ex ipsius sapientiae stirpe generatum. nam et de duobus auis iam diximus, Scipione et Crasso, et de tribus proauis, Q. Metello, cuius quattuor filii, P. Scipione, qui ex dominatu Ti. Gracchi priuatus in libertatem rem publicam uindicauit, Q. Scaeuola augure, qui peritissimus iuris idemque percomis est habitus.

(213) iam duorum abauorum quam est inlustre nomen, P. Scipionis qui bis consul fuit, qui est Corculum dictus, alterius omnium sapientissimi, C. Laeli! O generosam, inquit, stirpem et tamquam in unam arborem plura genera sic in istam domum multorum insitam atque inluminatam sapientiam! [59] LIX. Similiter igitur suspicor, ut conferamus parua magnis, Curionis, etsi pupillus relictus est, patrio fuisse instituto puro sermone adsuefactam domum; et eo magis hoc iudico, quod neminem ex his quidem, qui aliquo in numero fuerunt, cognoui in omni genere honestarum artium tam indoctum tam rudem. (214) nullum ille poetam nouerat, nullum legerat
Crasso. [212] - Que tu pensas, perguntei, de Crasso, aquele filho desta Licínia, que foi adotado no testamento de Crasso? Dizem que ele tinha um grande talento, respondeu, e quanto a Cipião, o que foi meu colega, a meu ver não apenas falava mas também discursava muito bem. - Você está certo, Bruto, continuei. E, de fato, sua família foi gerada pela raiz da própria sabedoria. Com efeito, não só já falamos dos dois avôs, Cipião e Crasso, mas também dos três bisavôs, Quinto Metelo, com seus quatro filhos, Públio Cipião, que como simples cidadão defendeu a liberdade da república da dominação de Tibério Graco, Quinto Cévola, o áugure, que era renomado pela sua grande perícia no direito e também pela sua grande amabilidade.

[213] Quanto aos dois trisavôs: quão ilustre é o nome de Públio Cipião, que foi cônsul duas vezes, que é chamado de Corculo; e do outro, do mais sábio de todos, Caio Lélio. Ó, nobre estirpe, retrucou, e tal como em uma única árvore há muitos troncos, do mesmo modo nesta casa foi plantada e [....] a sabedoria de muitos. De modo semelhante, então, suponho, a fim de que comparemos coisas pequenas a grandes, Curião, embora cedo tenha se tornado órfão, por iniciativa de seu pai viveu numa casa acostumada a uma linguagem pura, e estou cada vez mais convencido disso pelo fato de que não conheci ninguém, entre aqueles que tiveram algum valor, tão pouco instruído e tão rude em todos os gêneros das belas artes. [214] Ele não havia conhecido nenhum poeta, não 
oratorem, nullam memoriam antiquitatis conlegerat; non publicum ius, non priuatum et ciuile cognouerat. quamquam id quidem fuit etiam in aliis et magnis quidem oratoribus, quos parum his instructos artibus uidimus, ut Sulpicium, ut Antonium. sed ei tamen unum illud habebant dicendi opus elaboratum; idque cum constaret ex quinque notissimis partibus, nemo in aliqua parte earum omnino nihil poterat: in quacumque enim una plane clauderet, orator esse non posset; sed tamen alius in alia excellebat magis. (215) reperiebat quid dici opus esset et quo modo praeparari et quo loco locari, memoriaque ea comprendebat Antonius, excellebat autem actione; erantque ei quaedam ex his paria cum Crasso, quaedam etiam superiora; at Crassi magis nitebat oratio. nec uero Sulpicio neque Cottae dicere possumus neque cuiquam bono oratori rem ullam ex illis quinque partibus plane atque omnino defuisse.

(216) itaque in Curione hoc uerissime iudicari potest, nulla re una magis oratorem commendari quam uerborum splendore et copia. nam cum tardus in cogitando tum in struendo dissipatus fuit. [60] LX. Reliqua duo sunt, agere et meminisse: in utroque cacinnos inridentium commouebat. motus erat is, quem et $\mathrm{C}$. Iulius in perpetuum notauit, cum ex havia lido nenhum orador, nem possuído nenhum conhecimento de história, não tinha conhecimento do direito público nem do privado nem do civil. Embora isso acontecesse também com outros e com grande oradores, que observamos serem pouco instruídos nessas artes, como Sulpício, como Antônio. Mas eles, no entanto, possuíam algo único: uma atividade oratória aperfeiçoada, e como ela é constituída de cinco partes bem conhecidas, não havia quem ignorasse completamente qualquer uma de suas partes. É que não poderia ser um orador quem não se conduzisse bem em qualquer uma delas, mas, no entanto, alguns se distinguem mais em cada uma delas. [215] Antônio descobria o que era necessário dizer, de que modo deveria dispor e em que lugar deveria colocar e guardava tudo na memória, mas distinguía-se na atuação, e em algumas delas ele se igualava a Crasso, em umas até superava; por outro lado, o que mais reluzia em Crasso era a linguagem. Na verdade, nem a Sulpício, nem a Cota nem a nenhum outro bom orador podemos dizer que carecia inteira e completamente de alguma dessas cinco partes.

[216] Por isso, é possível afirmar com convicção a respeito de Curião que nenhuma qualidade por si só valoriza mais o orador do que o brilho e a riqueza das palavras. De fato, não só era lento na reflexão mas sobretudo no arranjo disperso. Restam duas coisas: pronunciar e memorizar: em ambas levava os gozadores a gargalhadas. Ele tinha um movimento que não só Caio Júlio notabilizou para sem- 
eo in utramque partem toto corpore uacillante quaesiuit, quis loqueretur e lintre; et Cn. Sicinius homo impurus sed admodum ridiculus - neque aliud in eo oratoris simile quicquam. (217) is cum tribunus plebis Curionem et Octauium consules produxisset Curioque multa dixisset sedente Cn. Octauio conlega, qui deuinctus erat fasciis et multis medicamentis propter dolorem artuum delibutus, 'numquam, inquit, Octaui, conlegae tuo gratiam referes; qui nisi se suo more iactauisset, hodie te istic muscae comedissent.' memoria autem ita fuit nulla, ut aliquotiens, tria cum proposuisset, aut quartum adderet aut tertium quaereret; qui in iudicio priuato uel maxumo, cum ego pro Titinia Cottae perorauissem, ille contra me pro Ser. Naeuio diceret, subito totam causam oblitus est idque ueneficiis et cantionibus Titiniae factum esse dicebat. (218) Magna haec immemoris ingeni signa; sed nihil turpius quam quod etiam in scriptis obliuiscebatur quid paulo ante posuisset: ut in eo libro, ubi se exeuntem e senatu et cum Pansa nostro et cum Curione filio conloquentem facit, cum senatum Caesar consul habuisset, omnisque ille sermo ductus est a percontatione fili quid in senatu esset actum. in quo multis uerbis cum inueheretur in Caesarem Curio disputatioque esset inter eos, ut est consuetudo dialogorum, cum pre quando perguntou balançando o corpo para os dois lados quem estava falando em uma canoa, mas também Gneo Sicínio, homem vil mas que conduzia ao riso - e não havia nada nele semelhante a um orador. [217] Ele, quando era tribuno da plebe, tinha apresentado os cônsules Curião e Otávio à assembleia, depois que Curião havia discursado longamente enquanto seu colega Gneo Otávio estava sentado, obrigado a ficar impregnado de faixas e muitos unguentos por causa de dores nas articulações, "você, Otávio, nunca será capaz de retribuir o seu colega," exclamou, "se ele não tivesse se agitado como de costume, hoje as moscas teriam comido você aqui." $\mathrm{E}$ sua memória era tão nula que algumas vezes quando havia proposto falar três coisas acrescentava a quarta ou não encontrava a terceira. Em uma causa privada muito importante, após eu ter feito a peroração depois de Cota em defesa de Titínia, ele discursava contra mim em defesa de Sérvio Névio quando subitamente se esqueceu completamente a causa e dizia que aquilo tinha acontecido pelos feitiços e encantos de Titínia. [218] Esses são fortes sinais de um engenho desmemoriado, mas nada é mais vergonhoso do que ter se esquecido, até mesmo em seus escritos, do que havia afirmado um pouco antes. Como naquele livro, em que ele se representa saindo do senado conversando com nosso Pansa e com seu filho Curião, depois de uma sessão do senado presidida pelo cônsul César, e toda aquela conversa tinha se iniciado porque o filho tinha perguntado o que havia sido dis- 
sermo esset institutus senatu misso, quem senatum Caesar consul habuisset, reprendit eas res, quas idem Caesar anno post et deinceps reliquis annis administrauisset in Gallia.

[61] LXI. (219) Tum Brutus admirans: tantamne fuisse obliuionem, inquit, in scripto praesertim, ut ne legens quidem umquam senserit quantum flagiti commisisset? Quid autem, inquam, Brute, stultius quam, si ea uituperare uolebat quae uituperauit, non eo tempore instituere sermonem, cum illarum rerum iam tempora praeterissent? sed ita totus errat, ut in eodem sermone dicat in senatum se Caesare consule non accedere, sed id dicat ipso consule exiens e senatu. iam qui hac parte animi, quae custos est ceterarum ingeni partium, tam debilis esset, ut ne in scripto quidem meminisset quid paulo ante posuisset, huic minime mirum est ex tempore dicenti solitam effluere mentem. (220) itaque cum ei nec officium deesset et flagraret studio dicendi, perpaucae ad eum causae deferebantur. orator autem, uiuis eius aequalibus, proxumus optumis numerabatur propter uerborum bonitatem, ut ante dixi, et expeditam ac profluentem quodam modo celeritatem. itaque eius cutido no senado. A partir disso, Curião atacou César com muitas palavras, e se desenvolvia uma discussão entre eles, como é costume nos diálogos, embora a conversa tenha sido instituída após sair do senado, senado que era presidido pelo cônsul César, repreendia os feitos do mesmo César que havia sido governador da Gália no ano seguinte e depois nos anos sucessivos.

[219] Então, Bruto admirado disse: Mas havia tanto esquecimento, e ainda mais num escrito, que nem mesmo numa leitura podia perceber que havia incorrido num erro tão torpe? - Mas o que pode, Bruto, ser mais estúpido, respondi, se ele queria vituperar o que vituperou, do que não estabelecer a conversa numa época em que aqueles eventos já tivessem se tornado passado? Mas se engana tão completamente que afirma na mesma conversa que enquanto César fosse cônsul não iria ao senado, mas o afirma saindo do senado sendo cônsul César. Ora, quem é tão débil nessa parte do ânimo, que é a guardiã das outras partes do engenho, que não seria capaz de recordar nem mesmo daquilo que, por escrito, tinha afirmado um pouco antes, não é de se admirar que, ao discursar de improviso, a memória costumava escapar-lhe. [220] Por isso, embora não lhe faltasse o sentimento do dever e tivesse um ardente desejo de discursar em público, poucas causas foram levadas a ele. Mas como orador, dos que viveram na sua geração, era considerado quem mais se aproximava dos melhores pela excelência, como disse antes, pela agilidade, bem como por 
orationes aspiciendas tamen censeo. sunt illae quidem languidiores, uerum tamen possunt augere et quasi alere id bonum, quod in illo mediocriter fuisse concedimus: quod habet tantam uim, ut solum sine aliis in Curione speciem oratoris alicuius effecerit. sed ad instituta redeamus.

[62] LXII (221) In eodem igitur numero eiusdem aetatis C. Carbo fuit, illius eloquentissimi uiri filius. non satis acutus orator, sed tamen orator numeratus est. erat in uerbis grauitas et facile dicebat et auctoritatem naturalem quandam habebat oratio. acutior Q. Varius rebus inueniendis nec minus uerbis expeditus; fortis uero actor et uehemens et uerbis nec inops nec abiectus et quem plane oratorem dicere auderes Cn. Pomponius lateribus pugnans, incitans animos, acer acerbus, criminosus. (222) Multum ab his aberat L. Fufius, tamen ex accusatione M. Aquili diligentiae fructum ceperat. nam M. Drusum tuum magnum auonculum, grauem oratorem ita dumtaxat cum de re publica diceret, L. autem Lucullum etiam acutum, patremque tuum, Brute, iuris quo que et publici et priuati sane peritum, M. Lucullum, M. Octauium Cn. f., qui tantum auctoritate dicendoque ualuit ut legem Semproniam frumentariam populi frequentis subfragiis uma fluente presteza nas palavras. Por isso, penso que seus discursos, contudo, devem ser observados. Eles são um pouco fracos, é verdade, todavia podem acrescentar e, por assim dizer, alimentar aquela aptidão, que reconhecemos existir nele medianamente, algo que possui tanta força que, por si só, sem outras qualidades, dava a Curião certa aparência de orador. Mas voltemos ao nosso propósito.

[221] Na mesma categoria, portanto, na mesma época esteve Caio Carbo, filho de um homem eloquentíssimo. Orador não tão perspicaz, e, no entanto, foi considerado orador. Havia solenidade nas palavras, discursava com facilidade, e sua eloquência possuía certa autoridade natural. Quinto Vário, mais perspicaz para encontrar os argumentos e não menos diligente nas palavras; por outro lado, de atuação vigorosa e veemente, não deficiente nem trivial nas palavras, e que tranquilamante arriscarias chamar de orador, Gneu Pompônio, que lutava com os pulmões, incitava os ânimos, penetrante, cruel, agressivo. [222] Muito se afastava desses Lúcio Fúfio e, no entanto, na acusação a Mário Aquílio colhera o fruto da diligência. Com efeito, quanto a M. Druso, teu tio-avô, orador veemente tão somente quando discursava pela república, quanto a Lúcio Luculo, que também possuía agudeza, e a teu pai, Bruto, também grande perito no direito não só público como também privado, quanto a Marco Luculo, a Marco Otávio, filho de Gneu, cuja autoridade e eloquência tiveram tanta força que ele revogou 
abrogauerit, Cn. Octauium M. f., M. Catonem patrem, Q. etiam Catulum filium abducamus ex acie id est ab iudiciis et in praesidiis rei publicae, cui facile satis facere possint, conlocemus. (223) Eodem Q. Caepionem referrem, nisi nimis equestri ordini deditus a senatu dissedisset. Cn. Carbonem, M. Marium et ex eodem genere compluris minime dignos elegantis conuentus auribus aptissimos cognoui turbulentis contionibus. quo in genere, ut in his perturbem aetatum ordinem, nuper L. Quinctius fuit; aptior etiam Palicanus auribus imperitorum.

(224) Et quoniam huius generis facta mentio est, seditiosorum omnium post Gracchos L. Appuleius Saturninus eloquentissimus uisus est: magis specie tamen et motu atque ipso amictu capiebat homines quam aut dicendi copia aut mediocritate prudentiae. longe autem post natos homines improbissimus C. Seruilius Glaucia, sed peracutus et callidus cum primisque ridiculus. is ex summis et fortunae et uitae sordibus in praetura consul factus esset, si rationem eius haberi licere iudicatum esset. nam et plebem tenebat et equestrem ordinem beneficio legis deuinxerat. is praetor eodem die, a lei Semprônia de distribuição de grãos com grande maioria dos votos populares, quanto a Gneu Otávio, filho de Marco, a Marco Catão pai, também a Quinto Cátulo filho, retiremo-los da linha de combate, isto é, dos tribunais e coloquemo-los nas guarnições da república, onde mais facilmente possam cumprir seu dever. [223] Colocaria aqui também Quinto Cepião, se não houvesse divergido com o senado em razão de sua excessiva devoção à ordem equestre. Gneu Carbão, Marco Mário e diversos outros do mesmo gênero eu reconheci que eram nada dignos dos ouvidos de uma audiência cultivada, muitíssimo hábeis nos tumultuados tribunais. A este gênero, para que eu perturbe entre eles a sequência cronológica, há pouco pertenceu Lúcio Quíncio, e ainda mais hábil aos ouvidos dos ignorantes foi Palicano.

[224] E já que foi feita menção a esse gênero de oradores, de todos os sediciosos posteriores aos Graco, Lúcio Apuleio Saturnino pareceu o meis eloquente: cativava, entretanto, mais pelo aspecto e pelo gesto e até mesmo pelo modo de portar a toga do que pela riqueza do discurso ou pela modesta prudência. Mas, de longe, desde que o mundo é mundo o mais ímprobo de todos foi Caio Servílio Gláucia, porém era penetrante e astuto, bem como um dos mais espirituosos. De uma condição extremamente baixa não só pela fortuna como também pelo modo de vida, teria sido eleito cônsul durante sua pretura, se sua candidatura fosse julgada legítima. De fato, tanto controlava a plebe como havia 
quo Saturninus tribunus plebis, Mario et Flacco consulibus publice est interfectus; homo simillimus Atheniensis Hyperboli, cuius improbitatem ueteres Atticorum comoediae notauerunt. (225) Quos Sex. Titius consecutus, homo loquax sane et satis acutus sed tam solutus et mollis in gestu, ut saltatio quaedam nasceretur, cui saltationi Titius nomen esset. ita cauendumst, ne quid in agendo dicendoue facias, cuius imitatio rideatur. [63] LXIII. sed ad paulo superiorem aetatem reuecti sumus; nunc ad eam de qua aliquantum sumus locuti reuertamur. (226) Coniunctus igitur Sulpici aetati P. Antistius fuit, rabula sane probabilis, qui multos cum tacuisset annos neque contemni solum sed inrideri etiam solitus esset, in tribunatu primum contra C. Iuli illam consulatus petitionem extraordinariam ueram causam agens est probatus; et eo magis quod eandem causam cum ageret eius conlega ille ipse Sulpicius, hic plura et acutiora dicebat. itaque post tribunatum primo multae ad eum causae, deinde omnes maxumae quaecumque erant deferebantur. (227) Rem uidebat acute, componebat diligenter, memoria ualebat; uerbis non ille quidem ornatis utebatur, sed tamen non abiectis; expedita autem erat et perfacile currens oratio; et erat eius quidam tamquam habitus non inurbanus; actio paulum cum uitio uocis tum etiam conquistado a ordem equestre pelo favor de uma lei. Quando era pretor, no mesmo dia em que o tribuno da plebe Saturnínio, no consulado de Mário e Flaco, foi morto por decisão pública: homem muito semelhante ao ateniense Hipérbolo, cuja improbidade os poetas da velha comédia ática notabilizaram. [225] Segue-se a esses Sexto Tício, homem realmente loquaz e bastante agudo, mas tão lânguido e afeminado no gesto que surgiu certa dança cujo nome era "dança de Tício". Assim, é necessário ter precaução para evitar no gesticular e no discursar tudo aquilo cuja imitação faça rir. Mas nós voltamos a uma época muito anterior, agora voltemos àquela sobre a qual já falamos um pouco. [226] Então, à época de Sulpício pertenceu Públio Antístio, um rábula realmente louvável, que durante muitos anos havia silenciado, sendo habitualmente não só desprezado como também ridicularizado, em seu tribunado atuando pela primeira vez numa causa justa contra a candidatura ilegal de Caio Júlio ao consulado, e tanto mais porque nessa mesma causa em que atuava seu colega, o famoso Sulpício, ele discursou com mais amplitude e agudeza. Por isso, depois do tribunado a princípio lhe foram confiadas muitas causas, em seguida todas de maior importância. [227] Observava o caso com agudeza, dispunha o argumento cuidadosamente, possuía boa memória; na verdade, ele não se valia de uma linguagem ornada mas, no entanto, não abjeta; seu discurso, porém, era fluente e discorria com facilidade; e havia nele como que uma 
ineptiis claudicabat. hic temporibus floruit iis, quibus inter profectionem reditumque L. Sullae sine iure fuit et sine ulla dignitate res publica; hoc etiam magis probabatur, quod erat ab oratoribus quaedam in foro solitudo. Sulpicius occiderat, Cotta aberat et Curio; uiuebat e reliquis patronis eius aetatis nemo praeter Carbonem et Pomponium, quorum utrumque facile superabat.

[64] LXIV. (228) Inferioris autem aetatis erat proxumus L. Sisenna, doctus uir et studiis optimis deditus, bene Latine loquens, gnarus rei publicae, non sine facetiis, sed neque laboris multi nec satis uersatus in causis; interiectusque inter duas aetates Hortensi et Sulpici nec maiorem consequi poterat et minori necesse erat cedere. huius omnis facultas ex historia ipsius perspici potest, quae cum facile omnis uincat superiores, tum indicat tamen quantum absit a summo quamque genus hoc scriptionis nondum sit satis Latinis litteris inlustratum. nam Q. Hortensi admodum adulescentis ingenium ut Phidiae signum simul aspectum et probatum est. (229) Is L. Crasso Q. Scaeuola consulibus primum in foro dixit et apud hos ipsos quidem consules, et cum eorum qui adfuerunt tum ipsorum consulum, qui omnibus intellegentia anteibant, iudicio discessit probatus. undeuiginti an- expressão oratória nada rústica; a atuação coxeava um pouco, seja pelo defeito da voz, seja por outras inépcias. Ele floresceu naqueles anos entre a partida e a volta de Sila quando não havia legalidade nem a mínima dignidade, também por isso era mais estimado, porque o fórum era um deserto de oradores. Sulpício havia morrido, Cota e Curião estavam ausentes, dos demais patronos de sua época nenhum estava vivo, exceto Carbo e Pompônio, a ambos os quais superava facilmente.

[228] Da época seguinte, porém, o mais próximo era Lúcio Sisena, homem douto e dedicado aos excelentes estudos, falando um bom latim, conhecedor dos assuntos públicos, não desprovido de graça mas não era muito laborioso nem bastante versado nas causas, e entreposto entre duas épocas, de Hortênsio e de Sulpício, não podia se igualar ao mais velho e era necessário ceder ao mais jovem. Todo seu engenho pode ser percebido a partir da história que ele escreveu, que conquanto vença facilmente todas as anteriores, indica todavia quão longe está da excelência e de quanto brilho ainda carece este gênero de escrita nas letras latinas. Com efeito, o engenho de Quinto Hortênsio, absolutamente jovem, como uma estátua de Fídias, logo que foi visto, foi louvado. [229] Ele, no consulado de Lúcio Crasso e Quinto Cévola, pela primeira vez discursou no fórum, e justamente na presença dos próprios cônsules, e tanto na opinião dos que estavam presentes como dos próprios cônsules, que pela inteligência estavam à frente de to- 
nos natus erat eo tempore, est autem L. Paullo C. Marcello consulibus mortuus: ex quo uidemus eum in patronorum numero annos quattuor et quadraginta fuisse. hoc de oratore paulo post plura dicemus; hoc autem loco uoluimus eius aetatem in disparem oratorum aetatem includere. quamquam id quidem omnibus usu uenire necesse fuit, quibus paulo longior uita contigit, ut et cum multo maioribus natu, quam essent ipsi, et cum aliquanto minoribus compararentur. ut Accius isdem aedilibus ait se et Pacuuium docuisse fabulam, quom ille octoginta, ipse triginta annos natus esset: (230) Sic Hortensius non cum suis aequalibus solum, sed et mea cum aetate et cum tua, Brute, et cum aliquanto superiore coniungitur, si quidem et Crasso uiuo dicere solebat et magis iam etiam uigebat Antonio; et cum Philippo iam sene pro $\mathrm{Cn}$. Pompei bonis dicens in illa causa, adulescens cum esset, princeps fuit et in eorum, quos in Sulpici aetate posui, numerum facile peruenerat et suos inter aequalis $\mathrm{M}$. Pisonem M. Crassum Cn. Lentulum P. Lentulum Suram longe praestitit et me adulescentem nactus octo annis minorem, quam erat ipse, multos annos in studio eiusdem laudis exercuit et tecum simul, sicut ego pro multis, sic ille pro Appio Claudio dixit paulo ante mortem. dos, saiu de lá aprovado. Tinha dezenove anos na ocasião e morreu no consulado de Lúcio Paulo e Caio Marcelo: a partir disso vemos que ele pertenceu à categoria dos patronos durante quarenta e quatro anos. Sobre este orador falaremos mais logo em seguida; nesse momento, porém, quisemos inserir sua vida entre gerações diversas de oradores. Aliás, o que necessariamente sucedeu a todos aqueles cuja vida foi um pouco mais longa, que não só eram comparados com os muito mais velhos que eles próprios mas também com um grande número de mais jovens. Como por exemplo Ácio diz que ele e Pacúvio no mesmo ano compuseram dramas, quando este tinha oitenta e ele próprio trinta anos. [230] Do mesmo modo, Hortênsio está ligado não só a seus contemporâneos mas tanto à minha época como à tua, Bruto, bem como a uma bastante anterior, uma vez que, por um lado, costumava discursar sendo Crasso vivo, por outro, sendo Antônio conquistava ainda mais influência; e discursando com Filipo já velho em defesa dos bens de Gneo Pompeu, naquela causa, conquanto fosse jovem, foi o principal orador, e facilmente atingira a categoria daqueles que situei na época de Sulpício; e de longe esteve à frente de seus contemporâneos Marco Pisão, Marco Crasso, Gneo Lêntulo e Públio Lêntulo Sura; e na minha juventude, oito anos mais novo que ele, durante muito anos suscitou em mim o desejo da mesma glória, e ao mesmo tempo, como fiz em muitas defesas, discursou contigo na defesa de Ápio Cláudio pouco antes de 
[65] LXV. (231) Vides igitur, ut ad te oratorem, Brute, peruenerimus tam multis inter nostrum tuumque initium dicendi interpositis oratoribus; ex quibus, quoniam in hoc sermone nostro statui neminem eorum qui uiuerent nominare, ne uos curiosius eliceretis ex me quid de quoque iudicarem, eos qui iam sunt mortui nominabo. Tum Brutus: non est, inquit, ista causa quam dicis, quam ob rem de is qui uiuunt nihil uelis dicere. Quaenam igitur, inquam, est? Vereri te, inquit, arbitror ne per nos hic sermo tuus emanet et ii tibi suscenseant, quos praeterieris. Quid? uos, inquam, tacere non poteritis? Nos quidem, inquit, facillime; sed tamen te arbitror malle ipsum tacere quam taciturnitatem nostram experiri. (232) Tum ego: uere tibi, inquam, Brute, dicam. non me existimaui in hoc sermone usque ad hanc aetatem esse uenturum; sed ita traxit ordo aetatum orationem, ut iam ad minoris etiam peruenerim. Interpone igitur, inquit, si quos uidetur; deinde redeamus ad te et ad Hortensium. Immo uero, inquam, ad Hortensium; de me alii dicent, si qui uolent. Minime uero, inquit. nam etsi me facile omni tuo sermone tenuisti, tamen is mihi longior uidetur, quod propero audire de te; nec uero tam de uirtutibus dicendi tuis, quae cum omnibus tum certe mihi notissi- morrer.

[231] Está vendo, então, Bruto, que para chegarmos à sua carreira oratória, tantos são os oradores interpostos entre o meu e o seu discurso de estréia; entre os quais, visto que em nossa conversa estabeleci não mencionar ninguém que estivesse vivo, para que voces, bastante curiosos, não extirpassem de mim o meu juízo sobre alguém, mencionarei aqueles que já morreram. Bruto, então, retrucou: — Não é pela causa que você afirma que você não quer falar sobre aqueles que estão vivos. Qual é, então? perguntei. - Creio que você teme, respondeu, que por nós esta sua conversa se espalhe e que se irritem contigo aqueles que você tiver preterido. Como? Você não são capazes de manter silêncio? Perguntei. — Nós, facilmente, respondeu. Mas, no entanto, vejo que você prefere que você mesmo se cale a por à prova o nosso silêncio. [232] Eu, então, repliquei: - Serei sincero com você, Bruto. Não pensei que com esta conversa eu chegaria à nossa época, mas a sucessão das épocas levou nosso discurso até que chegássemos também aos mais jovens. - Então, interponha quem quiser, ele disse, em seguida, voltemos a você e a Hortêncio. — Sim, repliquei, mas a Hortêncio; sobre mim, outros falarão, se lhes aprouver. Não! Pelo contário, retrucou. De fato, embora me tenha facilmente cativado em todo seu discurso, no entanto, ele me parece muito longo, porque ansioso em ouvir sobre você, e, na verdade, nem tanto pelas suas virtudes oratórias, que não só a todos 
mae sunt, quam quod gradus tuos et quasi processus dicendi studeo cognoscere.

(233) Geretur, inquam, tibi mos, quoniam me non ingeni praedicatorem esse uis sed laboris mei. uerum interponam, ut placet, alios et a M. Crasso, qui fuit aequalis Hortensi, exordiar. [66] LXVI. Is igitur mediocriter a doctrina instructus, angustius etiam a natura, labore et industria et quod adhibebat ad obtinendas causas curam etiam et gratiam, in principibus patronis aliquot annos fuit. in huius oratione sermo Latinus erat, uerba non abiecta, res compositae diligenter, nullus flos tamen neque lumen ullum, animi magna, uocis parua contentio, omnia fere ut similiter atque uno modo dicerentur. nam huius aequalis et inimicus $\mathrm{C}$. Fimbria non ita diu iactare se potuit; qui omnia magna uoce dicens uerborum sane bonorum cursu quodam incitato ita furebat tamen, ut mirarere tam alias res agere populum, ut esset insano inter disertos locus. (234) Cn. autem Lentulus multo maiorem opinionem dicendi actione faciebat quam quanta in eo facultas erat; qui cum esset nec peracutus, quamquam et ex facie et ex uoltu uidebatur, nec abundans uerbis, etsi fallebat in eo ipso, sic interuallis, exclamationibus, uoce suaui et canora, admirando inridebat, calebat in agendo, mas também a mim são conhecidíssimas, quanto porque espero conhecer seus passos e, por assim dizer, sua progressão na oratória.

[233] — Farei do seu modo, continuei, porquanto quer que eu seja proclamador não de meu engenho mas de meu esforço. A bem dizer, vou incluir outros, como lhe apraz, e começarei com Marco Crasso, que foi contemporâneo de Hortêncio. Ora, ele, sendo dotado de instrução mediana, de natureza ainda mais limitada, pelo seu esforço e dedicação e porque para ser bem sucedido em suas causas recorria ao zelo e até mesmo ao favor, esteve alguns anos entre os principais patronos. Em seu discurso, havia uma linguagem correta, termos não grosseiros, argumentos arranjados cuidadosamente, nenhum floreio, no entanto, e brilho nenhum, grande agitação no ânimo, pequena na voz, de sorte que, no mais das vezes, tudo era dito de modo semelhante e monótono. Com efeito, não pôde gesticular por muito tempo seu contemporâneo e adversário Caio Fímbria, que discursando sempre com voz forte num fluxo acelerado de palavras verdadeiramente boas, todavia, se enfurecia tanto que te seja admirável que o povo em outro momento tenha dado a esse insano um lugar entre os eloquentes. [234] Gneu Lêntulo, porém, com sua ação, alcançava maior reputação oratória que seu tamanho talento permitia, e como não fosse perspicaz, ainda que parecesse tanto pela expressão como pelo gesto, nem abundante nas palavras, se bem que enganava nisso também; com as pausas, 
ut ea quae derant non desiderarentur. ita tamquam Curio copia nonnulla uerborum, nullo alio bono, tenuit oratorum locum: (235) Sic Lentulus ceterarum uirtutum dicendi mediocritatem actione occultauit, in qua excellens fuit. nec multo secus $P$. Lentulus, cuius et excogitandi et loquendi tarditatem tegebat formae dignitas, corporis motus plenus et artis et uenustatis, uocis et suauitas et magnitudo. sic in hoc nihil praeter actionem fuit, cetera etiam minora quam in superiore.

[67] LXVII. (236) M. Piso quicquid habuit, habuit ex disciplina maxumeque ex omnibus qui ante fuerunt Graecis doctrinis eruditus fuit. habuit a natura genus quoddam acuminis quod etiam arte limauerat, quod erat in reprehendendis uerbis uersutum et sollers sed saepe stomachosum, nonnumquam frigidum, interdum etiam facetum. is laborem quasi cursum forensem diutius non tulit, quod et corpore erat infirmo et hominum ineptias ac stultitias, quae deuorandae nobis sunt, non ferebat iracundiusque respuebat siue morose, ut putabatur, siue ingenuo liberoque fastidio. is cum satis floruisset adulescens, minor haberi est coeptus postea. deinde ex uirginum iudicio magnam laudem est adeptus et ex eo as exclamações, com voz agradável e harmoniosa, $[. . .$.$] inflamava-se na atuação,$ que não se sentia falta daquilo que faltava. Desse modo, tal como Curião, por certa riqueza de palavras, nehuma outra virtude, obteve um lugar entre os oradores,[235] assim também Lêntulo ocultou a mediocridade das demais virtudes oratórias com a atuação, na qual foi superior. Não muito diferente, Públio Lêntulo, de quem a morosidade tanto da invenção como da elocução cobria a dignidade da aparência, o movimento corporal pleno tanto de arte como de beleza, tanto a suavidade como a grandeza de voz. Desse modo, nada havia nele além da ação, no restante era inferior também ao precedente.

[236] Tudo que Marco Pisão obteve, obteve pelo estudo, e, muito mais que todos que viveram antes, foi instruído nas doutrinas gregas. Recebeu da natureza um tipo de agudeza que havia limado com a arte, porque era astucioso e habilidoso no retrucar, mas frequentemente irritante, algumas vezes afetado, outras vezes jocoso. Ele não suportou por muito tempo o ônus da, por assim dizer, carreira forense, porque era não só fraco de corpo mas também não suportava a inépcia e a estupidez dos homens, as quais temos de engolir, e muito irritado as repudiava seja pelo seu modo intransigente, como se pensava, seja pela sua pura e franca repugnância. Ele, como florescesse bastante na juventude, depois disso, passou a ser considerado menor. Em seguida, alcançou grande estima com o processo das vestálias e, naquele momento, por assim 
tempore quasi reuocatus in cursum tenuit locum tam diu, quam ferre potuit laborem; postea quantum detraxit ex studio tantum amisit ex gloria. (237) P. Murena mediocri ingenio sed magno studio rerum ueterum, litterarum et studiosus et non imperitus, multae industriae et magni laboris fuit. C. Censorinus Graecis litteris satis doctus, quod proposuerat explicans expedite, non inuenustus actor sed iners et inimicus fori. L. Turius paruo ingenio sed multo labore, quoquo modo poterat, saepe dicebat; itaque ei paucae centuriae ad consulatum defuerunt.

(238) C. Macer auctoritate semper eguit, sed fuit patronus propemodum diligentissimus. huius si uita, si mores, si uoltus denique non omnem commendationem ingeni euerteret, maius nomen in patronis fuisset. non erat abundans, non inops tamen; non ualde nitens, non plane horrida oratio; uox gestus et omnis actio sine lepore; at in inueniendis componendisque rebus mira accuratio, ut non facile in ullo diligentiorem maioremque cognouerim, sed eam ut citius ueteratoriam quam oratoriam diceres. hic etsi etiam in publicis causis probabatur, tamen in priuatis inlustriorem obtinebat locum. dizer, reconvocado à carreira, permaneceu na posição tanto tempo quanto necessário para poder suportar o ônus; depois disso, o quanto foi trazido pelo estudo, tanto foi perdido pela glória. [237] Surgiu Públio Murena, de engenho mediano, mas de muita aplicação ao estudo das antiguidades, não só aplicado mas também nào ignorante em letras, de muito zelo e muito esforço. Caio Censorino foi bem instruído nas letras gregas, desenvolvendo com desenvoltura o que se havia proposto, não era deselegante ator, mas inábil e inimigo do fórum. Lúcio Túrio, de escasso engenho, mas muito esforço, muitas vezes discursava da maneira como podia; por isso, poucas centúrias lhe faltaram para o consulado.

[238] Caio Macro sempre careceu de prestígio, mas foi um patrono dos mais diligentes. Se sua vida, seus hábitos, sua fisionomia, enfim, não tivessem arruinado toda reputação de seu engenho, teria maior renome entre os patronos. Não era abundante, nem pobre, entretanto; uma linguagem não muito elegante, nem totalmente rude; na voz, no gesto e em toda ação não havia graça; todavia uma extraordinária meticulosidade em encontrar e dispor os argumentos, que dificilmente encontrarei em outro tamanha diligência e grandeza, mas que se poderia afirmar ser mais movida à velhacaria que à oratória. Embora ele também fosse reconhecido nas causas públicas, no entanto, obteve um lugar mais importante nas causas privadas. 
[68] LXVIII. (239) C. deinde Piso statarius et sermonis plenus orator, minime ille quidem tardus in excogitando, uerum tamen uoltu et simulatione multo etiam acutior quam erat uidebatur. nam eius aequalem M. Glabrionem bene institutum aui Scaeuolae diligentia socors ipsius natura neglegensque tardauerat. etiam L. Torquatus elegans in dicendo, in existimando admodum prudens, toto genere perurbanus. meus autem aequalis Cn. Pompeius uir ad omnia summa natus maiorem dicendi gloriam habuisset, nisi eum maioris gloriae cupiditas ad bellicas laudes abstraxisset. erat oratione satis amplus, rem prudenter uidebat; actio uero eius habebat et in uoce magnum splendorem et in motu summam dignitatem. (240) Noster item aequalis D. Silanus, uitricus tuus, studi ille quidem habuit non multum, sed acuminis et orationis satis. Q. Pompeius A. f., qui Bithynicus dictus est, biennio quam nos fortasse maior, summo studio dicendi multaque doctrina, incredibili labore atque industria, quod scire possum: fuit enim mecum et cum M. Pisone cum amicitia tum studiis exercitationibusque coniunctus. huius actio non satis commendabat orationem; in hac enim satis erat copiae, in illa autem leporis parum. (241) Erat eius aequalis P. Autronius uoce peracuta atque magna nec alia re ulla
[239] Em seguida, surgiu Caio Pisão, orador estático e de linguagem mais informal, ao menos não era lento no raciocinar; mas, no entanto, pela expressão e pela simulação também parecia bem mais perspicaz do que, de fato, era. Com efeito, tendo seu contemporâneo Mário Glabrione sido bem iniciado pelos cuidados do avô Cévola, sua desleixada e negligente natureza o detivera. Lúcio Torquato também tinha um discurso elegante, uma reflexão bastante prudente, de modo geral, extremamente refinado. Meu contemporâneo, porém, Gneu Pompeu, varão nascido para a extrema grandiosidade, teria tido maior glória na oratória, se o desejo de maior glória o não tivesse desviado para as honras bélicas. Tinha uma linguagem bastante ampla, encontrava o argumento com prudência; sua ação, de fato, possuía não só grande esplendor na voz, mas também extrema dignidade no movimento. [240] Igualmente meu contemporâneo, Décimo Silano, teu padrasto, ele, de fato, não se empenhava muito, mas possuía agudeza e expressão suficientes. Quinto Pompeu, filho de Aulo, que era chamado de bitínio, aproximadamente dois anos mais velho que eu, de extrema dedicação à oratória e de grande instrução, de incrível esforço e diligência; o que posso afirmar: com efeito, esteve junto comigo e com Marco Pisão não só na amizade como também nos estudos e nos exercícios oratórios. Sua atuação não fazia jus à sua linguagem, nesta, de fato, havia riqueza suficiente, naquela, porém, pouca graça. [241] Eram seus contempo- 
probabilis, et L- Octauius Reatinus, qui cum multas iam causas diceret, adulescens est mortuus - is tamen ad dicendum ueniebat magis audacter quam parate - , et C. Staienus, qui se ipse adoptauerat et de Staieno Aelium fecerat, feruido quodam et petulanti et furioso genere dicendi: quod quia multis gratum erat et probabatur, ascendisset ad honores, nisi in facinore manifesto deprehensus poenas legibus et iudicio dedisset.

[69] LXIX. (242) Eodem tempore C. L. Caepasii fratres fuerunt, qui multa opera, ignoti homines et repentini, quaestores celeriter facti sunt, oppidano quodam et incondito genere dicendi. addamus huc etiam, ne quem uocalem praeterisse uideamur, C. Cosconium Calidianum, qui nullo acumine eam tamen uerborum copiam, si quam habebat, praebebat populo cum multa concursatione magnoque clamore. quod idem faciebat Q. Arrius, qui fuit M. Crassi quasi secundarum. is omnibus exemplo debet esse quantum in hac urbe polleat multorum oboedire tempori multorumque uel honori uel periculo seruire. (243) His enim rebus infimo loco natus et honores et pecuniam et gratiam consecutus etiam in patronorum - sine doctrina, sine ingenio - aliquem numerum peruenerat. sed ut pugiles inexercitati, etiam si râneos Públio Autrônio, louvável por sua voz muito aguda e grandiosa e nenhuma outra qualidade, Lúcio Otávio de Reate, que, quando já havia começado a discursar em muitas causas, morreu jovem - ele, no entanto, discursava com mais audácia que preparação -, e Caio Estaieno, que adotou a si mesmo e de Estaieno se fez Élio, de um gênero oratório um tanto férvido, petulante e furioso, com o qual, porque era reconhecido e louvado por muitos, teria alcançado as honras, se, apanhado em crime manifesto, não tivesse sido condenado às sanções das leis e do processo.

[242] No mesmo período, havia os irmãos Caio e Lúcio Cepasio, que com grande esforço, homens desconhecidos e chegando de repente, rapidamente se tornaram questores, um tanto provincianos e descuidados no gênero oratório. Acrescentemos também aqui, para que não pareça que preterimos quem teve voz, Caio Cosconio Calidiano, que sem nenhuma agudeza, entretanto aquela abundância de palavras, se possuía alguma, oferecia ao povo com muita afluência e grande aclamação. O mesmo que fazia Quinto Árrio, que foi como que o coadjuvante de Marco Crasso. Ele deve ser exemplo a todos nesta cidade de quanto seja eficaz estar disponível à necessidade de muitos e estar a serviço, seja da honra, seja do perigo de muitos. [243] Em razão disso, de fato, tendo nascido de família inferior, tendo conseguido não só honras como dinheiro e influência sem instrução e sem engenho -, alcançara também certa estima entre os patronos. 
pugnos et plagas Olympiorum cupidi ferre possunt, solem tamen saepe ferre non possunt, sic ille cum omni iam fortuna prospere functus labores etiam magnos excepisset, illius iudicialis anni seueritatem quasi solem non tulit. (244) Tum Atticus: tu quidem de faece, inquit, hauris idque iam dudum, sed tacebam; hoc uero non putabam, te usque ad Staienos et Autronios esse uenturum. Non puto, inquam, existimare te ambitione me labi, quippe de mortuis; sed ordinem sequens in memoriam notam et aequalem necessario incurro. uolo autem hoc perspici, omnibus conquisitis, qui in multitudine dicere ausi sint, memoria quidem dignos perpaucos, uerum qui omnino nomen habuerint, non ita multos fuisse. sed ad sermonem institutum reuertamur.

[70] LXX. (245) T. Torquatus T. f. et doctus uir ex Rhodia disciplina Molonis et a natura ad dicendum satis solutus atque expeditus, cui si uita suppeditauisset, sublato ambitu consul factus esset, plus facultatis habuit ad dicendum quam uoluntatis. itaque studio huic non satisfecit, officio uero nec in suorum necessariorum causis nec in sententia senatoria defuit. (246) Etiam M. Pon-
Mas, tal como os pugilistas inexperientes, mesmo se na ânsia da vitória olímpica são capazes de suportar socos e pancadas, não são, no entanto, capazes, no mais das vezes, de suportar o sol do meio dia, do mesmo modo ele, como também, tendo já passado por tudo com fortuna favorável, padecesse de grandes sofrimentos, não suportou a austeridade daquele ano judicial, como que o sol do meio dia. [244] Ático, então, disse: - É que você exaure a borra e isso já há algum tempo, mas eu silenciava; na verdade, não pensava que você fosse chegar até os Estaienos e os Autrônios. - Não espero, continuei, que você imagine que sou levado por interesse, pois diz respeito aos mortos; mas seguindo a sucessão inevitavelmente me embato com um período conhecido e contemporâneo. Quero, porém, que se perceba o seguinte, entre todos os perseverantes, que ousaram discursar diante de uma multidão, pouquíssimos realmente dignos de memória; na verdade, os que mereceram o nome com todas as letras também não foram muitos. Mas voltemos ao estabelecido em nossa conversa.

[245] Tito Torquato, filho de Tito, varão não só instruído na doutrina ródia de Mólon como também por natureza de discurso bastante fluente e desembaraçado, se a vida lhe fosse mais abundante, eliminada a corrupção eleitoral, teria se tornado cônsul, possuía mais talento que disposição para discursar. Por isso, seu esforço não foi suficiente, com o dever, porém, não faltou nas causas de seus camaradas nem nas deliberações senatoriais. [246] Marco Pon- 
tidius municeps noster multas priuatas causas actitauit, celeriter sane uerba uoluens nec hebes in causis uel dicam plus etiam quam non hebes, sed efferuescens in dicendo stomacho saepe iracundiaque uehementius; ut non cum aduersario solum sed etiam, quod mirabile esset, cum iudice ipso, cuius delinitor esse debet orator, iurgio saepe contenderet. M. Messalla minor natu quam nos, nullo modo inops, sed non nimis ornatus genere uerborum; prudens acutus, minime incautus patronus, in causis cognoscendis componendisque diligens, magni laboris, multae operae multarumque causarum. (247) Duo etiam Metelli, Celer et Nepos nihil in causis uersati nec sine ingenio nec indocti hoc erant populare dicendi genus adsecuti. Cn. autem Lentulus Marcellinus nec umquam indisertus et in consulatu pereloquens uisus est, non tardus sententiis, non in ops uerbis, uoce canora, facetus satis. C. Memmius L. f. perfectus litteris sed Graecis, fastidiosus sane Latinarum, argutus orator uerbisque dulcis, sed fugiens non modo dicendi uerum etiam cogitandi laborem, tantum sibi de facultate detraxit quantum imminuit industriae.

[71] LXXI (248) Hoc loco Brutus: quam uellem, inquit, de his etiam oratoribus qui hodie sunt tibi dicere luberet; et si de aliis minus, de duobus tamen quos a te scio laudari tídio, meu concidadão, também atuou em muitas causas privadas, desenvolvendo as palavras de modo realmente ágil, não era ignorante nas causas, ou direi também que era mais que não ignorante, mas efervescente ao discursar, muitas vezes com mau humor e irascibilidade e tão veemente, que se opunha, muitas vezes, não só ao adversário mas também, o que era admirável, ao próprio juízo do litígio, cujo apaziguador deve ser um orador. Marco Messala, nascido depois de mim, de uma espécie de linguagem de modo algum escassa, mas não muito ornada, patrono prudente, pespicaz, nada incauto, diligente ao analisar e planejar as causas, com grande esforço, com muito cuidado e em muitas causas. [247] E também os dois Metelos, Célere e Nepos, não experientes nas causas e não sem engenho nem iletrados, perseguiram o gênero oratório popular. Gneu Lêntulo Marcelino, porém, jamais deselegante e que pareceu muito eloquente no consulado, não moroso nos argumentos, não escasso nas palavras, de voz harmoniosa, bastante jocoso. Caio Mêmio, filho de Lúcio, excelente mas nas letras gregas, absolutamente avesso às latinas, orador arguto e suave nas palavras, mas, fugindo do esforço não apenas de discursar como também de refletir, tanto rebaixou sua capacidade quanto diminuiu seu empenho.

[248] Nesse ponto, Bruto disse: Como eu gostaria que lhe agradasse falar também sobre os oradores que há hoje, e se não sobre outros, no entanto sobre dois, os quais sei que costumam serem louvados 
solere, Caesare et Marcello, audirem non minus lubenter quam audiui de iis qui fuerunt. Cur tandem? inquam; an exspectas quid ego iudicem de istis qui tibi sunt aeque noti ac mihi? Mihi mehercule, inquit, Marcellus satis est notus, Caesar autem parum; illum enim saepe audiui, hic, cum ego iudicare iam aliquid possem, afuit. (249) Quid igitur de illo iudicas quem saepe audisti? Quid censes, inquit, nisi id quod habiturus es similem tui? Ne ego, inquam, si itast, uelim tibi eum placere quam maxume. Atqui et ita est, inquit, et uementer placet; nec uero sine causa. nam et didicit et omissis ceteris studiis unum id egit seseque cotidianis commentationibus acerrume exercuit. (250) Itaque et lectis utitur uerbis et frequentibus sententis, splendore uocis, dignitate motus fit speciosum et inlustre quod dicitur, omniaque sic suppetunt, ut ei nullam deesse uirtutem oratoris putem; maxumeque laudandus est, qui hoc tempore ipso, cum liceat in hoc communi nostro et quasi fatali malo, consoletur se cum conscientia optumae mentis tum etiam usurpatione et renouatione doctrinae. uidi enim Mytilenis nuper uirum atque, ut dixi, uidi plane uirum. itaque cum eum antea tui similem in dicendo uiderim, tum uero nunc a doctissimo uiro tibique, ut intellexi, amicissimo Cratippo instructum omni copia multo uidebam por você, César e Marcelo, ouviria de não menos bom grado quanto ouvi sobre os que se foram. - Ora, por quê? indaguei. Por acaso aguarda o meu juízo sobre estes que são conhecidos seus e igualmente meus? - Certamente, exclamou, Marcelo me é bastante conhecido, César, porém, pouco; de fato, aquele ouvi muitas vezes, este, no momento em que eu já era capaz de julgar algo, esteve ausente. [249] — Qual é, então, sua opinião sobre aquele que você ouviu muitas vezes? - Que você acha, disse, se não que seja considerado semelhante a você? - Sim, respondi. Sendo assim, espero que lhe agrade o mais possível. Mas é isso mesmo, completou, e me agrada muito e não sem razão. Com efeito, tanto se instruiu quanto se ocupou, depois de abandonar os demais estudos, com apenas um, bem como praticou cotidianamente exercícios oratórios com muito zelo. [250] Por isso, utiliza-se de palavras elegantes e argumentos densos, com o esplendor da voz, com a dignidade do movimento torna claro e brilhante o que se diz, e todas as qualidades de tal modo suficientes que penso que não lhe falta nenhuma virtude oratória; e, principalmente, deve ser louvado quem justamente nessa época, como se permite nesse nosso comum e como que calamidade fatal, se conforta não só na consciência da reta via mas também na prática e retomada dos estudos. De fato, vi o homem em Mitilene há pouco tempo e, como eu disse, vi o homem por inteiro. Por isso, não só antes me parecia que ele era semelhante a ti na oratória, como também 
similiorem. (251) Hic ego: etsi, inquam, de optumi uiri nobisque amicissimi laudibus lubenter audio, tamen incurro in memoriam communium miseriarum, quarum obliuionem quaerens hunc ipsum sermonem produxi longius. sed de Caesare cupio audire quid tandem Atticus iudicet. [72] LXXII. Et ille: praeclare, inquit, tibi constas, ut de iis qui nunc sint nihil uelis ipse dicere; et hercule si sic ageres, ut de iis egisti qui iam mortui sunt, neminem ut praetermitteres, ne tu in multos Autronios et Staienos incurreres. quare siue hanc turbam effugere uoluisti siue ueritus es ne quis se aut praeteritum aut non satis laudatum queri posset, de Caesare tamen potuisti dicere, praesertim cum et tuum de illius ingenio notissimum iudicium esset nec illius de tuo obscurum. (252) Sed tamen, Brute, inquit Atticus, de Caesare et ipse ita iudico et de hoc huius generis acerrumo existimatore saepissume audio, illum omnium fere oratorum Latine loqui elegantissume; nec id solum domestica consuetudine ut dudum de Laeliorum et Muciorum familiis audiebamus, sed quamquam id quoque credo fuisse, tamen, ut esset perfecta illa bene loquendi laus, multis litteris et iis quidem reconditis et exquisitis summoque studio et diligentia est consecutus: (253) Qui(n) etiam in maxumis occupationibus ad te ipsum, inquit in me agora me parece muito mais semelhante, instruído com toda copiosidade por Crátipo, homem doutíssimo e, como percebi, amicíssimo teu. [251] Nesse momento, eu disse: - Ainda que de bom grado ouça os elogios a um excelente homem e muito meu amigo, no entanto me embato com a recordação dos sofrimentos comuns, dos quais procurando o esquecimento, conduzi de modo mais prolongado a própria conversa. Mas desejo ouvir, enfim, o que Ático pensa sobre César. E ele disse: - É brilhante a sua coerência pelo fato de você mesmo não querer dizer nada sobre aqueles que estão vivos hoje; e, certamente, se você fizer tal como fez com aqueles que já morreram, de tal modo que não omita ninguém, que você se embata com muitos Autrônios e Estaienos. Pelo fato de que, ou bem você quis escapar desta turba, ou bem receoso de que alguém pudesse se queixar, seja por ter sido preterido, seja por não ser louvado o bastante, no entanto, poderia falar sobre César, sobretudo, por ser também muito conhecida a sua opinião sobre o talento dele, nem é desconhecida a dele sobre seu. [252] - Mas, no entanto, Bruto, disse Ático, a respeito de César, tanto penso como ouço muito frequentemente de quem é profundo conhecedor do assunto que entre quase todos os oradores ele fala o latim mais elegante, e não só por um hábito familiar, como há pouco ouvimos das famílias dos Lelios e dos Múcios, mas, embora eu creia que foi por isso também, como fosse completa a sua glória oratória, conseguiu, no entanto, por meio de muitos 
intuens, de ratione Latine loquendi accuratissume scripserit primoque in libro dixerit uerborum dilectum originem esse eloquentiae tribueritque, mi Brute, huic nostro, qui me de illo maluit quam se dicere, laudem singularem; nam scripsit his uerbis, cum hunc nomine esset adfatus: ac si, cogitata praeclare eloqui ut possent, nonnulli studio et usu elaborauerunt, cuius te paene principem copiae atque inuentorem bene de nomine ac dignitate populi Romani meritum esse existumare debemus: hunc facilem et cotidianum nouisse sermonem nunc pro relicto est habendum?

[73] LXXIII. (254) Tum Brutus: amice hercule, inquit, et magnifice te laudatum puto, quem non solum principem atque inuentorem copiae dixerit, quae erat magna laus, sed etiam bene meritum de populi Romani nomine et dignitate. quo enim uno uincebamur a uicta Graecia, id aut ereptum illis est aut certe nobis cum illis communicatum. (255) Hanc autem, inquit, gloriam testimoniumque Caesaris tuae quidem supplicationi non, sed triumphis multorum antepono. Et recte quidem, inquam, Brute; modo sit hoc Caesaris iudici, non beneuolentiae testimo- estudos, tanto os mais profundos como os mais refinados, e com extremo empenho e zelo. [253] E, mesmo em meio a importantes ocupações, para você, disse, olhando para mim, com muito rigor escreveu sobre o método oratório do bom latim e afirmou no início do livro que a boa escolha das palavras era a origem da eloquência; e, meu caro Bruto, conferiu ao nosso amigo, que preferiu que eu e não ele falasse sobre aquele, um elogio singular. De fato, depois de haver mencionado teu nome, escreveu nos seguintes termos: "e se alguns são capazes de expressar claramente seus pensamentos, que se empenharam no estudo e na prática, de cuja copiosidade devemos considerar-lhe quase o primeiro e inventor, digno do nome e do prestígio diante do povo romano; conhecer essa linguagem fácil e cotidiana é algo que agora deve se deixar de lado?"

[254] Então, Bruto disse: - Absolutamente! Penso que lhe foi feito um elogio amigável e honrado, a quem não só atribui ser o primeiro e o inventor da copiosidade, o que é um grande elogio, mas também ser digno do nome e do prestígio diante do povo romano. Com efeito, no único lugar em que éramos vencidos pela Grécia vencida, ou bem isso foi tomado por eles, ou bem compartilhado entre nós e eles. [255] Esta glória, porém, ele disse, e o testemunho de César ateponho não às preces públicas, mas aos triunfos de muitos. - Justamente, Bruto, continuei; visto que seja o testemunho de juíz de César, não de sua boa vontade. É que, certamente, mais 
nium. plus enim certe adtulit huic populo dignitatis quisquis est ille, si modo est aliquis, qui non inlustrauit modo sed etiam genuit in hac urbe dicendi copiam, quam illi qui Ligurum castella expugnauerunt: ex quibus multi sunt, ut scitis, triumphi. (256) Verum quidem si audire uolumus, omissis illis diuinis consiliis, quibus saepe constituta est imperatorum sapientia salus ciuitatis aut belli aut domi, multo magnus orator praestat minutis imperatoribus. 'at prodest plus imperator.' quis negat? sed tam en - non metuo ne mihi adclametis; est autem quod sentias dicendi liber locus - malim mihi L. Crassi unam pro M. Curio dictionem quam castellanos triumphos duo. 'at plus interfuit rei publicae castellum capi Ligurum quam bene defendi causam M. Curi'.

(257) Credo; sed Atheniensium quoque plus interfuit firma tecta in domiciliis habere quam Mineruae signum ex ebore pulcherrimum; tamen ego me Phidiam esse mallem quam uel optumum fabrum tignuarium. quare non quantum quisque prosit, sed quanti quisque sit ponderandum est; praesertim cum pauci pingere egregie possint aut fingere, operarii autem aut baiuli deesse non possint. (258) Sed perge, Pomponi, de Caesare et redde quae restant. [74] LXXIV. Solum quidem, inquit ille, et quasi fundamentum oratoris uides acrescentou prestígio a esse povo aquele que, se é que houve algum, não só celebrizou mas também gerou a copiosidade oratória nessa cidade, quanto aqueles que subjugaram as fortificações ligúrias, para os quais foram celebrados, vós sabeis, muitos triunfos. [256] Se queremos ouvir a verdade, omitidas as resoluções divinas, a partir das quais é instituída a sabedoria dos generais, a salvação da repúblicas, seja na guerra, seja na pátria, um grande orador supera em muito os pequenos generais. "Mas o general é mais útil!". Quem o nega? Mas, no entanto - não temo não ser aclamado por vós; aqui, porém, é um ambiente livre para dizer o que pensas -, preferiria um só pronunciamento de Lúcio Crasso em defesa de Mario Cúrio a dois triunfos miltares. "Mas, para a república, foi mais importante ter conquistado uma cidadela ligúria do que ter defendido a causa de Mário Cúrio".

[257] Sei. Mas também foi mais importante para os atenienses possuir um telhado firme em suas casas do que uma belíssima imagem em marfim da deusa Minerva; no entanto, preferiria eu ser um Fídias a ser ainda que o melhor carpinteiro. Por isso, deve-se ponderar não o quanto alguém seja útil, mas o quanto esse alguém valha; sobretudo porque poucos são capazes de pintar ou esculpir magnificamente; não se pode, porém, faltar operários e serventes. [258] Mas, continue, Pompônio, e acrescente o que falta sobre César. Vê-se que a base, disse ele, e como que o fundamento do orador é uma linguagem 
locutionem emendatam et Latinam, cuius penes quos laus adhuc fuit, non fuit rationis aut scientiae sed quasi bonae consuetudinis. mitto C. Laelium P. Scipionem: aetatis illius ista fuit laus tamquam innocentiae sic Latine loquendi - nec omnium tamen; nam illorum aequales Caecilium et Pacuuium male locutos uidemus - : sed omnes tum fere, qui nec extra urbem hanc uixerant neque eos aliqua barbaries domestica infuscauerat, recte loquebantur. sed hanc certe rem deteriorem uetustas fecit et Romae et in Graecia. confluxerunt enim et Athenas et in hanc urbem multi inquinate loquentes ex diuersis locis. quo magis expurgandus est sermo et adhibenda tamquam obrussa ratio, quae mutari non potest, nec utendum prauissima consuetudinis regula. (259) T. Flamininum, qui cum Q. Metello consul fuit, pueri uidimus: existumabatur bene Latine, sed litteras nesciebat. Catulus erat ille quidem minime indoctus, ut a te paulo est ante dictum, sed tamen suauitas uocis et lenis appellatio litterarum bene loquendi famam confecerat. Cotta, qui se ualde dilatandis litteris a similitudine Graecae locutionis abstraxerat sonabatque contrarium Catulo, subagreste quiddam planeque subrusticum, alia quidem quasi inculta et siluestri uia ad eandem laudem peruenerat. Sisenna autem quasi emen- pura e em bom latim, mérito que entre os que viveram até hoje se deu não pela reflexão ou pela teoria, mas como que pelo bom costume. Deixo de lado Caio Lélio e Públio Cipião: houve em sua época tal como o mérito da integridade moral também o da expressão do bom latim - não, no entanto, entre todos; pois vemos que seus contemporâneos Cecílio e Pacúvio falavam mal —, mas agora quase todos que não viveram fora da cidade, nem os deteriorou nenhum barbarismo doméstico, falam corretamente. Mas, sem dúvida, tanto em Roma como na Grécia essa situação se deteriora com o tempo. De fato, confluiram tanto para Atenas como para esta cidade muitos falantes com impurezas de diversos lugares. Donde a necessidade de se expurgar a linguagem e de se utilizar como que de uma boa regra como pedra de toque, que não possa ser mudada, e não se valer da regra muito errônea do costume. [259] Quando éramos meninos, conhecemos Tito Flamínio, que foi cônsul com Quinto Metelo: estimavase que falava um bom latim, mas não era formado nas letras. Cátulo não era nada inculto, como você disse antes, mas, no entanto, a suavidade da voz e a branda pronúncia das palavras haviam lhe conferido a fama de falar bem. Cota, que muito havia se afastado, ao extender as vogais, da semelhança com a pronúncia grega e que possuía um acento contrário ao de Cátulo, um tanto grosseiro e completamente rústico, por uma outra via como que inculta e silvestre alcançara a mesma glória. Sisena, porém, embora quisesse ser como que o 
dator sermonis usitati cum esse uellet, ne a C. Rusio quidem accusatore deterreri potuit quominus inusitatis uerbis uteretur. (260) Quidnam istuc est? inquit Brutus, aut quis est iste C. Rusius? Et ille: fuit accusator, inquit, uetus, quo accusante C. Hirtilium Sisenna defendens dixit quaedam eius sputatilica esse crimina. tum C. Rusius: 'circumuenior, inquit, iudices, nisi subuenitis. Sisenna quid dicat nescio; metuo insidias. sputatilica, quid est hoc? sputa quid sit scio, tilica nescio.' maxumi risus; sed ille tamen familiaris meus recte loqui putabat esse inusitate loqui.

[75] LXXV. (261) Caesar autem rationem adhibens consuetudinem uitiosam et corruptam pura et incorrupta consuetudine emendat. itaque cum ad hanc elegantiam uerborum Latinorum - quae, etiam si orator non sis et sis ingenuus ciuis Romanus, tamen necessaria est - adiungit illa oratoria ornamenta dicendi, tum uidetur tamquam tabulas bene pictas conlocare in bono lumine. hanc cum habeat praecipuam laudem in communibus, non uideo cui debeat cedere. splendidam quandam minimeque ueteratoriam rationem dicendi tenet, uoce motu forma etiam magnificam et generosam quodam modo. (262) Tum Brutus: orationes quidem eius mihi uehementer pro- reformador da linguagem usual, nem sequer foi capaz, na acusação de Caio Rusio, de se afastar do uso de palavras inusitadas. [260] — De que se trata? Perguntou Bruto. Ou melhor, quem é esse Caio Rusio? Ele, então, respondeu: - Foi um antigo acusador, que ao acusar Caio Histílio, Sisena, defendendo-o, afirmou que algumas de suas acusações eram SPUTATILICA. Então, Caio Rusio: "estou cercado, senhores juízes, se não me socorreis, disse. Não sei o que Sisena quer dizer, temo uma armadilha. SPUTATILICA, que é isto? Compreendo o que seja SPUTA, mas não compreendo TITILICA". E muitas gargalhadas. Mas, no entanto, esse meu amigo julgava que falar bem era falar de modo inusitado.

[261] César, porém, recorrendo a um princípio racional, corrige o vicioso e deteriorado uso com o uso puro e íntegro. Por isso, por um lado, a essa elegância dos termos latinos - que, no entanto, é necessária, embora orador não seja mas seja um livre cidadão romano - acrescenta os ornamentos da linguagem oratória; por outro lado, é como se colocasse as telas bem pintadas em boa luz. Enquanto obtem esse mérito notável entre as qualidades comuns, não vejo a quem deva ceder. Possuiu um método oratório esplêndido e que não se resume à experiência, e também de certo modo magnífico e nobre na voz, no movimento, na forma. [262] Bruto, então: Sim, seus discursos me agradaram muito. Li, porém, só alguns; e ele também escreveu alguns comentários sobre seus feitos. - 
bantur. compluris autem legi; atque etiam commentarios quosdam scripsit rerum suarum. Valde quidem, inquam, probandos; nudi enim sunt, recti et uenusti, omni ornatu orationis tamquam ueste detracta. sed dum uoluit alios habere parata, unde sumerent qui uellent scribere historiam, ineptis gratum fortasse fecit, qui uolent illa calamistris inurere: sanos quidem homines a scribendo deterruit; nihil est enim in historia pura et inlustri breuitate dulcius. sed ad eos, si placet, qui uita excesserunt, reuertamur.

[76] LXXVI. (263) C. Sicinius igitur Q. Pompei illius, qui censor fuit, ex filia nepos quaestorius mortuus est; probabilis orator, iam uero etiam probatus, ex hac inopi ad ornandum, sed ad inueniendum expedita Hermagorae disciplina. ea dat rationes certas et praecepta dicendi; quae si minorem habent apparatum — sunt enim exilia — , tamen habent ordinem et quasdam errare in dicendo non patientes uias. has ille tenens et paratus ad causas ueniens, uerborum non egens, ipsa illa comparatione disciplinaque dicendi iam in patronorum numerum peruenerat. (264) Erat etiam uir doctus in primis C. Visellius Varro consobrinus meus, qui fuit cum Sicinio aetate coniunctus. is cum post curulem aedilitatem iudex quaestionis esset, est mortuus; in quo fateor uolgi iudicium a iudi-
São realmente louváveis, acrescentei. Com efeito, são desnudos, simples e elegantes, como se fosse retirada a veste de todo ornamento do discurso. Mas, ao desejar que estivesse à disposição de outros os elementos donde possam se apropriar os que quiserem escrever história, fez talvez um bem aos ineptos, que desejarão frisá-los com calamístros; é verdade que homens sensatos dissuadiu de escrever; com efeito, nada é mais agradável em história que a pura e clara brevidade. Mas, se lhes apraz, voltemos àqueles que deixaram a vida.

[263] Então, Caio Sicino, neto por parte da filha de Quinto Pompeu, que foi censor, morreu durante sua questura; orador louvável, na verdade também louvado, formado pela doutrina de Hermágoras, escassa em ornamentos mas fluente em argumentos. O que fornece princípios firmes e preceitos do discurso oratório, se bem que contêm o mínimo de sofisticação - são, de fato, escassos -, no entanto, possuem uma ordem e certas vias para não serem sucetíveis a descaminhos do discurso. Conservando-as e chegando bem preparado para os processos judiciários, não sendo pobre nas palavras, ele já havia alcançado com essa mesma preparação e instrução oratórias um lugar na categoria dos patronos. [264] Estava também entre os mais importantes um varão culto, Caio Visélio Varrão, meu sobrinho, que foi contemporâneo a Sicino. Ele morreu quando, depois do cargo de edil, presidia um tribunal; a respeito de quem eu 
cio meo dissensisse. nam populo non erat satis uendibilis: praeceps quaedam et cum idcirco obscura, quia peracuta, tum rapida et celeritate caecata oratio; sed neque uerbis aptiorem cito alium dixerim neque sententiis crebriorem. praeterea perfectus in litteris iurisque ciuilis iam a patre Aculeone traditam tenuit disciplinam. (265) Reliqui sunt, qui mortui sint, L. Torquatus, quem tu non tam cito rhetorem dixisses, etsi non deerat oratio, quam, ut Graeci dicunt,

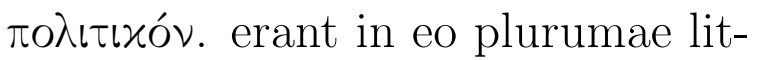
terae nec eae uolgares, sed interiores quaedam et reconditae, diuina memoria, summa uerborum et grauitas et elegantia; atque haec omnia uitae decorabat grauitas et integritas. me quidem admodum delectabat etiam Triari in illa aetate plena litteratae senectutis oratio. quanta seueritas in uoltu, quantum pondus in uerbis, quam nihil non consideratum exibat ex ore! (266) Tum Brutus Torquati et Triari mentione commotus - utrumque enim eorum admodum dilexerat - : ne ego, inquit, ut omittam cetera quae sunt innumerabilia, de istis duobus cum cogito, doleo nihil tuam perpetuam auctoritatem de pace ualuisse. nam nec istos excellentis uiros nec multos alios praestantis ciuis res publica perdidisset. Sileamus, inquam, Brute, de istis, ne augeamus dolorem. nam et praeteritorum recordatio est acerba confesso que a opinião do vulgo divergia da minha opinião. De fato, não era bem aceito pelo povo: um discurso um tanto precipitado e por isso não só obscuro, porque muito agudo, como também confuso pela rapidez e velocidade; mas não poderia mencionar outro mais capacitado na presteza das palavras nem mais numeroso nos argumentos. Além disso, bem instruído nas letras e no direito civil, conservou o ensinamento transmitido pelo pai Aculeão. [265] Há outros, que morreram, Lúcio Torquato, a quem não tão facilmente se poderia atribuir uma instrução retórica, embora não lhe faltasse capacidade oratória, quanto, como dizem os gregos, uma instrução to$\lambda เ \tau \iota x \eta^{2}$. Cultivaram-se nele muitas letras e não as vulgares, mas as mais profundas e sofisticadas, uma memória divina, uma extrema não só austeridade como também elegância; a austeridade e a integridade da vida condecoravam tudo isso. E me agradava muito também a eloquência de Triário nessa época plena de maturidade letrada. Quanta severidade no semblante, quanto peso nas palavras, quão refletido era tudo que lhe saía da boca. [266] Bruto, então, comovido pela menção a Torquato e a Triário - é que ambos lhe eram muito caros - : é verdade! $\mathrm{E}$ eu, disse, que omitirei demais fatos que são inumeráveis, quando penso neles dois, lamento que nada tenha valido teu ininterrupto conselho em prol da paz. De fato, a república não poderia ter perdido esses varões excelentes nem outros cidadãos importantes. Silenciemos sobre isso, Bruto, para que não aumen- 
et acerbior exspectatio reliquorum. itaque omittamus lugere et tantum quid quisque dicendo potuerit, quoniam id quaerimus, praedicemus.

\section{[77] LXXVII. (267) Sunt etiam ex} iis, qui eodem bello occiderunt, $\mathrm{M}$. Bibulus, qui et scriptitauit accurate, cum praesertim non esset orator, et egit multa constanter; Appius Claudius socer tuus, conlega et familiaris meus: hic iam et satis studiosus et ualde cum doctus tum etiam exercitatus orator et cum auguralis tum omnis publici iuris antiquitatisque nostrae bene peritus fuit. L. Domitius nulla ille quidem arte, sed Latine tamen et multa cum libertate dicebat. (268) duo praeterea Lentuli consulares, quorum Publius ille nostrarum iniuriarum ultor, auctor salutis, quicquid habuit, quantumcumque fuit, illud totum habuit e disciplina; instrumenta naturae derant; sed tantus animi splendor et tanta magnitudo, ut sibi omnia, quae clarorum uirorum essent, non dubitaret asciscere eaque omni dignitate obtineret. L. autem Lentulus satis erat fortis orator, si modo orator, sed cogitandi non ferebat laborem; uox canora, uerba non horrida sane, ut plena esset animi et terroris oratio; quaereres in iudiciis fortasse melius, in re publica quod erat esse iudicares satis. (269) Ne T. quidem Postu- temos nosso sofrimento. De fato, tanto a recordação do passado é amarga como mais amarga a expectativa do futuro. Por isso, deixemos de lamentar e tão somente exaltemos a qualidade que cada um possuía, já que investigamos isso.

[267] Havia também entre esses que morreram na mesma guerra, Mário Bibulo, que não só escrevia com primor, muito embora não fosse orador, mas também agia com sensatez; Ápio Cláudio, seu sogro, meu correligionário e amigo: ele foi um orador não só bastante empenhado, mas também tão bem instruído como experimentado e perito, tanto no direito augural como no público, bem como nos acontecimentos de nosso passado; Lúcio Domício, ele discursava sem nenhuma arte, mas, no entanto, em bom latim e com muita independência. [268] Ademais, dois Lêntulos consulares, dos quais Públio, o vingador das injustiças contra mim, promotor de minha saúde, tudo o que possuía, qualquer que seja a grandeza, adquiriu-o inteiramente pela instrução, faltavam-lhe os dons da natureza, mas havia tanto esplendor e tanta grandeza de ânimo que não hesitava em imputar a si tudo que havia nos varões ilustres e que o sustentava com toda dignidade. Lúcio Lêntulo, porém, era um orador bastante enérgico, se é que era orador, mas não se dava ao esforço da reflexão; voz harmoniosa, palavras não muito rudes, tanto que seu discurso era pleno de terror e animosidade; poderias talvez procurar nos tribunais algo melhor, nas questões públicas, o que havia poderias considerar sufi- 
mius contemnendus in dicendo; de re publica uero non minus uehemens orator quam bellator fuit, effrenatus et acer nimis, sed bene iuris publici leges atque instituta cognouerat. Hoc loco Atticus: putarem te, inquit, ambitiosum esse, si, ut dixisti, ii quos iam diu conligis uiuerent. omnis enim commemoras, qui ausi aliquando sunt stantes loqui, ut mihi imprudens M. Seruilium praeterisse uideare.

[78] LXXVIII. (270) Non, inquam, ego istuc ignoro, Pomponi, multos fuisse, qui uerbum numquam in publico fecissent, quom melius aliquanto possent quam isti oratores, quos colligo, dicere; sed his commemorandis etiam illud adsequor, ut intellegatis primum ex omni numero quam non multi ausi sint dicere, deinde ex iis ipsis quam pauci fuerint laude digni. (271) Itaque ne hos quidem equites Romanos amicos nostros, qui nuper mortui sunt, omittam, P. Cominium Spoletinum, quo accusante defendi C. Cornelium, in quo et compositum dicendi genus et acre et expeditum fuit; T. Accium Pisaurensem, cuius accusationi respondi pro A. Cluentio, qui et accurate dicebat et satis copiose, eratque praeterea doctus Hermagorae praeceptis, quibus etsi ornamenta non satis opima dicendi, tamen, ut hastae uelitibus amentatae, sic apta ciente. [269] Nem mesmo Tito Postúmio era desprezível na oratória; em verdade, foi para a república um orador não menos veemente que combatente, desenfreado e demasido violento, mas conhecia bem as leis e instituições do direito civil. Ático, nesse momento, disse: - Eu pensaria que alguma ambição lhe movia, se, como você disse, ainda vivessem aqueles que há algum tempo estás elencando. De fato, você traz à memória todos que alguma vez ousaram se levantar para discursar, tanto que me parece que the escapou Marco Servílio.

[270] — Eu não ignoro, Pompônio, respondi, que houve muitos que nunca proferiram uma palavra em público, embora fossem bem mais capazes de discursar que esses oradores que estou elencando, mas trazendo-os à memória também obtenho o seguinte: que, primeiramente, vocês compreendam que não muitos entre todos ousaram discursar em público; em seguida, que entre esses quão poucos foram dignos de louvor. [271] Por isso, não omitirei nem mesmo esses cavaleiros romanos, meus amigos, que morreram há pouco, Públio Comínio de Espoleto, de cuja acusação defendi Caio Cornélio, em quem era bem ordenado o modo de discursar, agudo e fluente; Tito Ácio de Pisauro, a cuja acusação contestei em defesa de Aulo Cluêntio, que discursava não só com zelo mas também com bastante copiosidade, e, ademais, instruído nos preceitos de Hermágoras, pelos quais, se bem que não se fornecem suficientemente os ricos ornamentos do discurso, no entanto, tal como lanças prontas para 
quaedam et parata singulis causarum generibus argumenta traduntur. (272) Studio autem neminem nec industria maiore cognoui, quamquam ne ingenio quidem qui praestiterit facile dixerim C. Pisoni, genero meo. nullum tempus illi umquam uacabat aut a forensi dictione aut a commentatione domestica aut a scribendo aut a cogitando. itaque tantos processus efficiebat ut euolare, non excurrere uideretur; eratque uerborum et dilectus elegans et apta et quasi rotunda constructio; cumque argumenta excogitabantur ab eo multa et firma ad probandum tum concinnae acutaeque sententiae; gestusque natura ita uenustus, ut ars etiam, quae non erat, et e disciplina motus quidam uideretur accedere. uereor ne amore uidear plura quam fuerint in illo dicere; quod non ita est: alia enim de illo maiora dici possunt. nam nec continentia nec pietate nec ullo genere uirtutis quemquam eiusdem aetatis cum illo conferendum puto.

[79] LXXIX. (273) Nec uero M. Caelium praetereundum arbitror, quaecumque eius in exitu uel fortuna uel mens fuit; qui quamdiu auctoritati meae paruit, talis tribunus plebis fuit, ut nemo contra ciuium perditorum popularem turbulentamque dementiam a senatu et a bonorum causa steterit constantius. quam eius actionem multum tamen os soldados, são fornecidos certos argumentos adequados e arranjados para cada um dos gêneros de causas. [272] Não conheci ninguém, porém, de maior empenho e zelo, ainda que pelo engenho fosse fácil mencionar alguém superior a Caio Pisão, meu genro. Ele nunca tinha tempo livre, ora discursando no fórum, ora preparando-se em casa, ora escrevendo, ora planejando discursos. Por isso, avançava tanto que parecia voar, não correr; e havia uma seleção elegante das palavras bem como um arranjo adequado e como que circular; e não só muitos e sólidos argumentos eram pensados por ele para sua demonstração, como também frases harmoniosas e penetrantes; e seu gesto era por natureza tão elegante que parecia acrescentar-se também a arte, que não havia, e derivar da instrução certos movimentos do corpo. Temo que pela afeição pareça que atribuo a ele mais do que havia, o que não procede: com efeito, coisas ainda maiores podem lhe ser atribuídas. De fato, penso que ninguém de sua época pode ser comparado a ele nem pelo autocontrole nem pela devoção nem por nenhuma outra espécie de virtude.

[273] Vejo que nem mesmo Marco Célio deve ser preterido, qualquer que tenha sido o motivo do seu fim, ou bem a fortuna, ou bem a intenção; que, durante o tempo em que esteve sob minha autoridade, foi um tribuno da plebe tal que ninguém se levantou com mais contundência contra a popular e turbolenta demência dos cidadãos depravados em prol do senado e da causa dos bons. No entanto, sua linguagem 
et splendida et grandis et eadem in primis faceta et perurbana commendabat oratio. graues eius contiones aliquot fuerunt, acres accusationes tres eaeque omnes ex rei publicae contentione susceptae; defensiones, etsi illa erant in eo meliora quae dixi, non contemnendae tamen saneque tolerabiles. hic cum summa uoluntate bonorum aedilis curulis factus esset, nescio quomodo discessu meo discessit a sese ceciditque, posteaquam eos imitari coepit quos ipse peruerterat.

(274) Sed de M. Calidio dicamus aliquid, qui non fuit orator unus e multis, potius inter multos prope singularis fuit: ita reconditas exquisitasque sententias mollis et pellucens uestiebat oratio. nihil tam tenerum quam illius comprensio uerborum, nihil tam flexibile, nihil quod magis ipsius arbitrio fingeretur, ut nullius oratoris aeque in potestate fuerit: quae primum ita pura erat ut nihil liquidius, ita libere fluebat ut nusquam adhaeresceret; nullum nisi loco positum et tamquam in uermiculato emblemate, ut ait Lucilius, structum uerbum uideres; nec uero ullum aut durum aut insolens aut humile aut (in) longius ductum; ac non propria uerba rerum, sed pleraque translata, sic tamen, ut ea non inruisse in alienum locum, sed immigrasse in suum diceres; nec uero haec soluta nec diffluentia, sed astricta nu- tanto continha esplendor como grandeza e também espirituosidade e muita urbanidade. Foram importantes alguns de seus discursos em assembleias, impetuosas as três acusaçãoes, e todas suscitadas pelo conflito na república; suas defesas, embora nele fossem melhores outras qualidades que apontei, no entanto, não são desprezíveis e realmente aceitáveis. Ele foi eleito edil curul com extremo consentimento dos bons, estando eu afastado não sei como se afastou de si mesmo e sucumbiu, depois de começar a imitar aqueles que ele mesmo havia derrubado.

[274] Mas falemos algo sobre Marco Calídio, que não foi um dos muitos oradores, antes foi quase único entre muitos: eis que sua eloquência suave e transparente se revestia com argumentos profundos e refinados. Nada tão brando quanto seu arranjo das palavras, nada tão flexível, nada que pudesse ser tão bem modelado por seu próprio arbítrio que nenhum orador possuía tal capacidade: em primeiro lugar, esse arranjo era tão puro que nada era mais límpido, fluía tão livremente que nunca se interrompia seu curso; nenhuma palavra que não tenhas visto colocada em seu lugar e como que disposta, como dizia Lucílio, num belo mosaico; nenhum termo, seja áspero, seja inusitado, seja modesto, seja trazido de muito longe; e não os termos próprios das coisas, mas em sua maioria metafóricos, de tal modo que, no entanto, seria dito que eles não invadiram um lugar alheio, mas migravam para seu lugar próprio; e eles não eram soltos nem espar- 
meris, non aperte nec eodem modo semper, sed uarie dissimulanterque conclusis. (275) Erant autem et uerborum et sententiarum illa lumina, quae uocant Graeci $\sigma \chi n ́ n \alpha \tau \alpha$, quibus tamquam insignibus in ornatu distinguebatur omnis oratio. 'qua de re agitur' autem illud, quod multis locis in iuris consultorum includitur formulis, id ubi esset uidebat.

(276) Accedebat ordo rerum plenus artis, actio liberalis totumque dicendi placidum et sanum genus. [80] LXXX. Quod si est optumum suauiter dicere, nihil est quod melius hoc quaerendum putes. sed cum a nobis paulo ante dictum sit tria uideri esse quae orator efficere deberet, ut doceret, ut delectaret, ut moueret, duo summe tenuit, ut et rem inlustraret disserendo et animos eorum qui audirent deuinciret uoluptate; aberat tertia illa laus, qua permoueret atque incitaret animos, quam plurumum pollere diximus; nec erat ulla uis atque contentio: siue consilio, quod eos quorum altior oratio actioque esset ardentior furere et bacchari arbitraretur, siue quod natura non esset ita factus siue quod non consuesset siue quod non posset. hoc unum illi, si nihil utilitatis habebat, afuit; si opus erat, defuit. ramados, mas ligados ao ritmo, não abertamente e nem sempre do mesmo modo, mas se harmonizando de modo variado e dissimulado. [275] Havia, porém, tanto aqueles ornamentos das palavras como dos argumentos, que os gregos chamam de $\sigma \chi \dot{\eta} \mu \alpha \tau \alpha$, com essas, digamos, insígnias do ornato se distinguia todo discurso. Quanto à expressão "de que se trata", que se encontra em muitas fórmulas dos jurisconsultos, sabia onde colocá-la.

[276] Juntava-se a isso um arranjo das matérias pleno de arte, uma ação elegante e um modo de discursar totalmente brando e sensato. E se a excelência é discursar com doçura, não há nada que consideres que se deva procurar melhor que ele. Mas; como há pouco eu afirmei que parecem ser três os fins que o orador deveria cumprir: que ensine, que deleite, que comova; com exterma competência granjeou dois deles, que tanto esclarecia a matéria discutindo como cativava pelo deleite os ânimos daqueles que ouviam; faltava-lhe aquela terceira qualidade que comove e incita os ânimos, que afirmamos possuir a maior força; e não havia nenhum vigor nem ímpeto: seja por deliberação, porque acreditava que aqueles cujo discurso era mais elevado e mais férvida a ação estavam em estado de furor e delírio báquico, seja porque a natureza o fez assim, seja porque não tinha o costume, seja porque não era capaz. Esta única qualidade, se não possuía nenhuma utilidade, lhe faltou, se era necessária, lhe careceu. 
(277) Quin etiam memini, cum in accusatione sua Q. Gallio crimini dedisset sibi eum uenenum parauisse idque a se esse deprensum seseque chirographa testificationes indicia quaestiones manifestam rem deferre diceret deque eo crimine accurate et exquisite disputauisset, me in respondendo, cum essem argumentatus quantum res ferebat, hoc ipsum etiam posuisse pro argumento, quod ille, cum pestem capitis sui, cum indicia mortis se comperisse manifesto et manu tenere diceret, tam solute egisset, tam leniter, tam oscitanter. (278) 'Tu istuc, M. Calidi, nisi fingeres, sic ageres? praesertim cum ista eloquentia alienorum hominum pericula defendere acerrume soleas, tuum neglegeres? ubi dolor, ubi ardor animi, qui etiam ex infantium ingeniis elicere uoces et querelas solet? nulla perturbatio animi, nulla corporis, frons non percussa, non femur; pedis, quod minimum est, nulla supplosio. itaque tantum afuit ut inflammares nostros animos, somnum isto loco uix tenebamus.' sic nos summi oratoris uel sanitate uel uitio pro argumento ad diluendum crimen usi sumus.

(279) Tum Brutus: atque dubitamus, inquit, utrum ista sanitas fuerit an uitium? quis enim non fateatur,
[277] Lembro-me, inclusive, de quando em sua acusação contra Quinto Gállio afirmava que este havia preparado um veneno contra ele e que havia sido descoberto por ele e que ele apresentou documentos escritos, testemunhos, indícios, confissões sob tortura, um fato evidente; e havia discorrido com cuidado e sutileza sobre o crime; em minha resposta, como houvesse argumentado o quanto o fato permitia, tomei isso como meu próprio argumento: o fato de que ele, embora afirmasse ter descoberto a ruína sobre sua cabeça e possuir com evidência e à mão indícios desejando sua morte, comportava-se com tanta tranquilidade, com tanta brandura, com tanta negligência. [278] "Mas você, Marco Calídio, se não tivesse forjado isso, agiria dessa maneira? Sobretudo pelo fato de que com tal eloquência tenha o costume de defender energicamente os perigos alheios, negligenciaria o seu próprio? Onde está a indignação? Onde está o ardor do ânimo? Que também costuma arrancar dos engenhos afônicos vozes e murmúrios. Nenhuma perturbação no ânimo, nenhuma no corpo, fisionomia não abatida, não impaciente, nenhuma batida de pé que é o mínimo. Por isso faltou tanto para que inflamasse nossos ânimos, nesse momento conseguíamos conter o sono com esforço". Assim, eu me utilizei, seja da sensatez, seja do vício de um orador excelente, em prol do argumento para diluir a acusação.

[279] Bruto, então, retrucou: — E duvidamos se esta sensatez não teria sido um vício. De fato, quem não há de convir que 
cum ex omnibus oratoris laudibus longe ista sit maxuma, inflammare animos audientium et quocumque res postulet modo flectere, qui hac uirtute caruerit, id ei quod maxumum fuerit defuisse? [81] LXXXI. Sit sane ita, inquam; sed redeamus ad eum, qui iam unus restat, Hortensium; tum de nobismet ipsis, quoniam id etiam, Brute, postulas, pauca dicemus. quamquam facienda mentio est, ut quidem mihi uidetur, duorum adulescentium, qui si diutius uixissent, magnam essent eloquentiae laudem consecuti. (280) C. Curionem te, inquit Brutus, et C. Licinium Caluum arbitror dicere. Recte, inquam, arbitraris; quorum quidem alter (quod uerisimile dixisset) ita facile soluteque uerbis uoluebat satis interdum acutas, crebras quidem certe sententias, ut nihil posset ornatius esse, nihil expeditius. atque hic parum a magistris institutus naturam habuit admirabilem ad dicendum; industriam non sum expertus, studium certe fuit. qui si me audire uoluisset, ut coeperat, honores quam opes consequi maluisset. Quidnam est, inquit, istuc? et quem ad modum distinguis? (281) Hoc modo, inquam. cum honos sit praemium uirtutis iudicio studioque ciuium delatum ad aliquem, qui eum sententiis, qui suffragiis adeptus est, is mihi et honestus et honoratus uidetur. qui autem occasione aliqua etiam inuitis uma vez que este é, de longe, o maior entre todos os méritos do orador: inflamar os ânimos dos ouvintes e movê-los para onde quer que o caso exija, quem carecesse dessa virtude lhe faltaria aquilo que é mais importante? - É exatamente isso, respondi, mas voltemos ao único que ainda resta: Hortêncio, e então, a mim mesmo, já que é você, Bruto, que solicita, falarei um pouco. Embora se deva fazer menção, como bem me parece, a dois jovens que, se tivessem vivido mais tempo, teriam alcançado imensa glória na eloquência. [280] - Penso, disse Bruto, que faz referência a Caio Curião e a Caio Licínio Calvo. - Pensou bem, continuei, o primeiro deles desenvolvia argumentos por vezes bastante agudos, abundantes é verdade, com tamanha facilidade e fluência nas palavras que não podia haver nada mais elegante, nada mais ágil. E com pouco ensinamento dos mestres possuía uma admirável capacidade oratória, não estive presente quando de sua atividade, certamente houve empenho. Se tivesse optado por me ouvir, como fizera no começo, teria preferido almejar as honras às riquezas. - Que queres dizer? Perguntou. E como você faz essa distinção? [281] — Do seguinte modo, respondi: visto que a honra seja a recompensa da virtude conferida a alguém por decisão e arbítrio dos cidadãos, que a obteve por decretos e sufrágios, isto me parece não só honesto como também honrado. Mas aquele que, em dada ocasião, chegou ao comando sem o consentimento dos cidadãos, conforme ele desejava, penso que conquistou só o nome da 
suis ciuibus nactus est imperium, ut ille cupiebat, hunc nomen honoris adeptum, non honorem puto. quae si ille audire uoluisset, maxuma cum gratia et gloria ad summam amplitudinem peruenisset, ascendens gradibus magistratuum, ut pater eius fecerat, ut reliqui clariores uiri. quae quidem etiam cum P. Crasso M. f., cum initio aetatis ad amicitiam se meam contulisset, saepe egisse me arbitror, cum eum uementer hortarer, ut eam laudis uiam rectissimam esse duceret, quam maiores eius ei tritam reliquissent. (282) Erat enim cum institutus optume tum etiam perfecte planeque eruditus, ineratque et ingenium satis acre et orationis non inelegans copia; praetereaque sine arrogantia grauis esse uidebatur et sine segnitia uerecundus. sed hunc quoque absorbuit aestus quidam insolitae adulescentibus gloriae; qui quia nauarat miles operam imperatori, imperatorem se statim esse cupiebat, cui muneri mos maiorum aetatem certam, sortem incertam reliquit. ita grauissumo suo casu, dum Cyri et Alexandri similis esse uoluit, qui suum cursum transcurrerant, et L. Crassi et multorum Crassorum inuentus est dissimillimus.

[82] LXXXII. (283) Sed ad Caluum - is enim nobis erat propositus - reuertamur; qui orator fuit cum litteris eruditior quam Curio tum etiam accuratius quoddam di- honra, não a própria honra. Se ele tivesse dado ouvido a isso, teria alcançado com extremo reconhecimento e distinção a mais alta posição, ascendendo na ordem das magistraturas, como fizera seu pai, como os demais cidadãos ilustres. E também com Públio Crasso, filho de Marco, que em sua juventude se aproximara de minha amizade, penso que tratei disso muitas vezes, quando o exortava com veemência a que se conduzisse naquela mais reta via que seus antepassados deixaram trilhada para ele. [282] De fato, obtivera não só uma excelente instrução como também uma perfeita e completa erudição, e nele havia tanto um engenho bastante penetrante como uma riqueza oratória não deselegante; e além disso aparentava gravidade sem soberba e modéstia sem negligência. Mas também o engoliu certa onda de glória inabitual aos mais jovens, pois como soldado que havia prestado sua ajuda ao comandante, comandante logo desejava se tornar, cargo para o qual o costume dos antigos estabeleceu idade determinada, sorte indeterminada. Desse modo, em sua violentíssima queda, enquanto queria ser semelhante a Alexandre e a Ciro, que rapidamente fizeram suas carreiras, revelou profunda dissemelhança em relação a Lúcio Crasso e a muitos outros Crassos.

[283] Mas voltemos a Calvo, o que, de fato, era nosso propósito; ele que foi orador não só mais erudito nas letras do que Curião, como também detinha um estilo oratório mais cuidadoso e mais refinado, 
cendi et exquisitius adferebat genus; quod quamquam scienter eleganterque tractabat, nimium tamen inquirens in se atque ipse sese obseruans metuensque, ne uitiosum conligeret, etiam uerum sanguinem deperdebat. itaque eius oratio nimia religione attenuata doctis et attente audientibus erat inlustris, multitudine autem et a foro, cui nata eloquentia est, deuorabatur. (284) Tum Brutus: Atticum se, inquit, Caluus noster dici oratorem uolebat: inde erat ista exilitas quam ille de industria consequebatur. Dicebat, inquam, ita; sed et ipse errabat et alios etiam errare cogebat. nam si quis eos, qui nec inepte dicunt nec odiose nec putide, Attice putat dicere, is recte nisi Atticum probat neminem. insulsitatem enim et insolentiam tamquam insaniam quandam orationis odit, sanitatem autem et integritatem quasi religionem et uerecundiam oratoris probat. haec omnium debet oratorum eadem esse sententia. (285) Sin autem ieiunitatem et siccitatem et inopiam, dummodo sit polita, dum urbana, dum elegans, in Attico genere ponit, hoc recte dumtaxat; sed quia sunt in Atticis aliis alia meliora, uideat ne ignoret et gradus et dissimilitudines et uim et uarietatem Atticorum. 'Atticos', inquit, 'uolo imitari.' quos? nec enim est unum genus. nam quid est tam dissimile quam Demosthenes et Lysias, quam embora o fizesse com conhecimento e elegância; no entanto, examinando-se em excesso, guardando-se e temendo que não incorresse em vício, perdia bastante vitalidade. Por isso, seu discurso, empobrecido pelo excesso de minúcia era claro para os doutos e para os ouvintes atentos, mas era mal digerido pela multidão e pelo fórum, para os quais nasceu a eloquência. [284] Bruto, então, disse: - Nosso amigo Calvo gostava de ser chamado de orador ático, daí vinha essa magreza que ele buscava deliberadamente. - Dizia sim, continuei. Mas tanto se enganava como levava outros a se enganarem. Com efeito, se quem pensa que aqueles que não discursam nem de modo grosseiro, nem afetado, nem pedante, discursam a maneira ática, ele certamente não estima ninguém que não seja ático. De fato, ele abomina o embotamento e a extravagância, tal como uma insanidade do discurso, mas estima a sobriedade e a pureza como que uma meticulosidade e moderação do orador. Esse deve ser o pensamento comum a todos os oradores. [285] Mas se, por outro lado, se estabelece como gênero ático a magreza e a secura e a simplicidade, contanto que seja polida, contanto que urbana, contanto que elegante, isso até que está bem; mas como entre os áticos umas qualidades são melhores que outras, atente-se para que não se ignore tanto os graus e dessemelhanças como a força e variedade dos áticos. "Quero imitar os áticos", alguém diz. Quais? E, de fato, não há um único gênero. Com efeito, o que é mais dessemelhante do 
idem et Hyperides, quam horum omnium Aeschines? quem igitur imitaris? si aliquem: ceteri ergo Attice non dicebant? si omnis: qui potes, cum sint ipsi dissimillumi inter se? in quo illud etiam quaero, Phalereus ille Demetrius Atticene dixerit. mihi quidem ex illius orationibus redolere ipsae Athenae uidentur. at est floridior, ut ita dicam, quam Hyperides, quam Lysias: natura quaedam aut uoluntas ita dicendi fuit. [83] LXXXIII. (286) Et quidem duo fuerunt per idem tempus dissimiles inter se, sed Attici tamen; quorum Charisius multarum orationum, quas scribebat aliis, cum cupere uideretur imitari Lysiam; Demochares autem, qui fuit Demostheni sororis filius, et orationes scripsit aliquot et earum rerum historiam, quae erant Athenis ipsius aetate gestae, non tam historico quam oratorio genere perscripsit. at Charisi uult Hegesias esse similis, isque se ita putat Atticum, ut ueros illos prae se paene agrestes putet. (287) At quid est tam fractum, tam minutum, tam in ipsa, quam tamen consequitur, concinnitate puerile? 'Atticorum similes esse uolumus.' optume; suntne igitur hi Attici oratores? 'quis negare potest? hos imitamur.' quo modo, qui sunt et inter se dissimiles et aliorum? 'Thucydidem' inquit 'imitamur.' optume, si historiam scribere, non si causas dicere cogitatis. Thucydides enim re- que Demóstenes e Lysias, do que aquele e Hypérides, do que todos esses e Ésquines? Quem, então, se pretende imitar? Ao se escolher algum deles, então, os outros não discursavam à maneira ática? Se são escolhidos todos, como é possível, uma vez que eles mesmos são dessemelhantes entre si? E aqui eu pergunto o seguinte: o famoso Demétrio de Falera falva à maneira ática ou não? A mim, pelo menos, dos seus discursos parecem exalar o próprio aroma de Atenas. Mas ele é, por assim dizer, mais florido do que Hypérides, do que Lysias: quer por sua natureza, quer por sua escolha, discursava dessa maneira. [286] E houve ao menos dois, no mesmo período, dissemelhantes entre si, e, contudo, áticos: Carísio, autor de muitos discursos, os quais escrevia para outros, pois parecia desejar imitar Lysias; Demócares, por sua vez, que era filho da irmã de Demóstenes, não só escreveu alguns discursos como também registrou a história dos acontecimentos da Atenas de seu tempo, não tanto à maneira do historiador quanto à do orador. Mas Hegésias pretendia ser semelhante a $\mathrm{Ca}-$ rísio, ele que se considera tão ático que, em comparação a si mesmo, considera os verdadeiros áticos quase rústicos. [287] O que há de tão afetado, tão minucioso, tão pueril naquela simetria que, no entanto, ele busca? "Queremos ser semelhantes aos áticos". Ótimo! Ora, eles são oradores áticos, não? "Quem pode negar? São eles que imitamos". Mas como, eles que são dissemelhantes não só entre si mas também em relação a outros? Eles dizem: "imitamos 
rum gestarum pronuntiator sincerus et grandis etiam fuit; hoc forense concertatorium iudiciale non tractauit genus. orationes autem, quas interposuit - multae enim sunt — eas ego laudare soleo: imitari neque possim, si uelim, nec uelim fortasse, si possim. ut si quis Falerno uino delectetur, sed eo nec ita nouo ut proximis consulibus natum uelit, nec rursus ita uetere ut Opimium aut Anicium consulem quaerat _ 'atqui hae notae sunt optumae': credo; sed nimia uetustas nec habet eam, quam quaerimus, suauitatem nec est iam sane tolerabilis — : (288) num igitur, qui hoc sentiat, si is potare uelit, de dolio sibi hauriendum putet? minime; sed quandam sequatur aetatem. sic ego istis censuerim et nouam istam quasi de musto ac lacu feruidam orationem fugiendam nec illam praeclaram Thucydidi nimis ueterem tamquam Anicianam notam persequendam. ipse enim Thucydides, si posterius fuisset, multo maturior fuisset et mitior.

[84] LXXXIV. (289) 'Demosthenem igitur imitemur.' o di boni! quid, quaeso, nos aliud agimus aut quid aliud optamus? at non adsequimur. isti enim uidelicet Attici
Tucídides". Ótimo, se pensam em escrever história, não se pensam em defender causas. De fato, Tucídides pronunciou com probidade e solenidade os acontecimentos históricos, não se ocupou com o gênero forense, contencioso, judicial. Os discursos que ele interpõe à narração - de fato, são muitos - tenho o costume de louvá-los, mas não poderia imitar, se quisesse, nem talvez quereria, se pudesse. Tal como a um apreciador do vinho de Falerno, mas que não o quisesse tão jovem a ponto de ter sido feito no ano anterior nem, pelo contrário, procurasse um tão envelhecido que remonte aos anos do consulado de Opímio e Anício - e creio que essas ânforas são as melhores, mas o envelhecimento demasiado não possui aquela suavidade que buscamos, e já não é mais apreciável — [288] Pois bem, se alguém que pensa dessa maneira quiser beber um vinho, acha que deve embeberse no dólio? De modo nenhum, e sim que procure um bom envelhecimento. Desta maneira, a esses eu aconselharia que tanto evitassem essa nova eloquência ainda em fermentação, um vinho, por assim dizer, mosto e em conservação, como também não procurassem a notável eloquência de Tucídides, demasiado antiga tal como uma ânfora do ano de Anício. Com efeito, se o próprio Tucídides fosse mais recente, ele teria sido bem mais maduro e doce.

[289] "Portanto, imitemos Demóstenes". Pelos deuses! E eu pergunto: o que mais procuramos ou o que mais desejamos? Mas não conseguimos. Ora, esses nossos áticos, sim, conseguem o que pretendem. Nem 
nostri quod uolunt adsequuntur. ne illud quidem intellegunt, non modo ita memoriae proditum esse sed ita necesse fuisse, cum Demosthenes dicturus esset, ut concursus audiendi causa ex tota Graecia fierent. at cum isti Attici dicunt, non modo a corona, quod est ipsum miserabile, sed etiam ab aduocatis relinquuntur. quare si anguste et exiliter dicere est Atticorum, sint sane Attici; sed in comitium ueniant, ad stantem iudicem dicant: subsellia grandiorem et pleniorem uocem desiderant. (290) Volo hoc oratori contingat, ut cum auditum sit eum esse dicturum, locus in subselliis occupetur, compleatur tribunal, gratiosi scribae sint in dando et cedendo loco, corona multiplex, iudex erectus; cum surgat is qui dicturus sit, significetur a corona silentium, deinde crebrae adsensiones, multae admirationes; risus, cum uelit, cum uelit, fletus: ut, qui haec procul uideat, etiam si quid agatur nesciat, at placere tamen et in scaena esse Roscium intellegat. haec cui contingant, eum scito Attice dicere, ut de Pericle audimus, ut de Hyperide, ut de Aeschine, de ipso quidem Demosthene maxume. (291) Sin autem acutum, prudens et idem sincerum et solidum et exsiccatum genus orationis probant nec illo grauiore ornatu oratorio utuntur et hoc proprium esse Atticorum uolunt, recte laudant. est enim in arte tanta tam- sequer compreendem aquilo que não só foi legado pela tradição mas também era tão necessário que acontecesse, que quando Demóstenes iria discursar toda a Grécia acorria para ouvi-lo. Estes áticos, porém, quando discursam, não só são abandonados pela multidão, o que já é deplorável, mas também pelos próprios apoiadores. Pois se discursar com extrema concisão e magreza é característica dos áticos, bem sejam áticos, mas apresentando-se nos comícios, discursando para juízes que permanecem de pé: os assentos da cúria esperam uma eloquência mais solene e mais robusta. [290] Quero que o orador consiga o seguinte: que ao se perceber que ele está prestes a discursar sejam ocupados os lugares nas cadeiras, sejam preenchidas as tribunas, os escribas estejam solícitos em indicar e ceder um lugar, muitos espectadores circundando, o juíz presidente atento; quando se apresente aquele que vai discursar, que os espectadores solicitem silêncio, que haja em seguida grande assentimento e muita admiração; o riso, quando quiser; quando quiser, o pranto: de modo que quem vir isso de longe, mesmo que não saiba o que se passa, no entanto compreenda que é um espetáculo agradável e que há um Róscio em cena. Saiba que quem consegue isso discursa à maneira ática, tal como ouvimos acerca de Péricles, acerca de Hipérides, acerca de Ésquines, e principalmente acerca do próprio Demóstenes. [291] Mas, se por outro lado, aprovam um gênero oratório agudo, sensato e ao mesmo tempo não só íntegro como também pleno 
que uaria etiam huic minutae subtilitati locus. ita fiet, ut non omnes qui Attice idem bene, sed ut omnes qui bene idem etiam Attice dicant. sed redeamus rursus ad Hortensium.

[85] LXXXV. (292) Sane quidem, inquit Brutus; quamquam ista mihi tua fuit periucunda a proposita oratione digressio. Tum Atticus: aliquotiens sum, inquit, conatus, sed interpellare nolui. nunc quoniam iam ad perorandum spectare uidetur sermo tuus, dicam, opinor, quod sentio. Tu uero, inquam, Tite. Tum ille: ego, inquit, ironiam illam quam in Socrate dicunt fuisse, qua ille in Platonis et Xenophontis et Aeschinis libris utitur, facetam et elegantem puto. est enim et minime inepti hominis et eiusdem etiam faceti, cum de sapientia disceptetur, hanc sibi ipsum detrahere, eis tribuere inludentem, qui eam sibi adrogant: ut apud Platonem Socrates in caelum effert laudibus Protagoram Hippiam Prodicum Gorgiam ceteros, se autem omnium rerum inscium fingit et rudem. decet hoc nescio quo modo illum, nec Epicuro, qui id reprehendit, adsentior. sed in historia, qua tu es usus in omni sermone, cum qualis quisque orator fuisset exponeres, e enxuto, e não se utilizam daquele ornamento mais vigoroso, e sustentam que isso é próprio dos áticos, louvam-nos com justiça. De fato, numa arte tão grande e tão variada há lugar para essa pequena sutileza. Assim, ocorre que nem todos que discursam à maneira ática o fazem bem, mas todos que o fazem bem, fazem-no à maneira ática. Mas voltemos novamente a Hortênsio.

[292] — Pois bem, disse Bruto, se bem que esta sua digressão do argumento me foi bastante agradável. Então, Ático disse: - Algumas vezes me dispus a lhe interromper, porém preferi não fazê-lo. Mas, já que seu discurso parece ter em vista sua peroração, creio que poderei dar minha opinião. - Mas é claro, Tito! Respondi. Então, ele disse: - Eu penso que aquela ironia, que dizem ter havido em Sócrates, da qual ele se utiliza nos livros de Platão, Xenofonte e Ésquines, era espirituosa e elegante. De fato, é próprio de um homem nada tolo e ao mesmo tempo espirituoso, quando se discute sobre a sabedoria, afastando-a de si mesmo, atribuindo-a com escárnio àqueles que arrogam-na para si: como em Platão, onde Sócrates com elogios eleva aos céus Protágoras, Hípias, Pródico, Górgias e outros, enquanto afeta em todos os assuntos ignorância e rudeza. Não sei de que modo isso lhe convém, nem concordo com Epicuro, que o repreende. Mas numa história, tal como vem desenvolvendo em todo seu discurso, apresentando as qualidades e as caracteríticas dos oradores que existiram, veja, eu lhe peço, se a ironia deve ser tão 
uide quaeso, inquit, ne tam reprehendenda sit ironia quam in testimonio. (293) Quorsus, inquam, istuc? non enim intellego. Quia primum, inquit, ita laudauisti quosdam oratores ut imperitos posses in errorem inducere. equidem in quibusdam risum uix tenebam, cum Attico Lysiae Catonem nostrum comparabas, magnum mercule hominem uel potius summum et singularem uirum - nemo dicet secus - sed oratorem? sed etiam Lysiae similem? quo nihil potest esse pictius. bella ironia, si iocaremur; sin adseueramus, uide ne religio nobis tam adhibenda sit quam si testimonium diceremus. (294) Ego enim Catonem tuum ut ciuem, ut senatorem, ut imperatorem, ut uirum denique cum prudentia et diligentia tum omni uirtute excellentem probo; orationes autem eius ut illis temporibus ualde laudo - significant enim formam quandam ingeni, sed admodum impolitam et plane rudem - , Origines uero cum omnibus oratoris laudibus refertas diceres et Catonem cum Philisto et Thucydide comparares, Brutone te id censebas an mihi probaturum? quos enim ne e Graecis quidem quisquam imitari potest, his tu comparas hominem Tusculanum nondum suspicantem quale esset copiose et ornate dicere.

[86] LXXXVI. (295) Galbam laudas. si ut illius aetatis principem, adsentior — sic enim accepimus - ; sin repreendida como num testemunho. [293] - Aonde você quer chegar? Perguntei. De fato, não compreendo. - Porque, em primeiro lugar, continuou, você elogiou tanto certos oradores que pode induzir os inexperientes ao erro. De minha parte, em certos casos com custo continha o riso, comparava ao ático Lísias nosso Catão, grande homem, absolutamente, ou antes uma personalidade excelente e distinta - ninguém há de negar -, mas orador? E, além do mais, semelhante a Lísias? Cujo colorido nada pode superar. Graciosa ironia, se quisermos ser jocosos; mas se falarmos com seriedade, veja se não devemos ser tão escrupulosos como se estivéssemos dando um testemunho. [294] É claro que eu louvo o seu Catão como cidadão, como senador, como imperator, como pessoa, enfim, excelente não só por sua prudência e zelo mas também por toda sua virtude; considero seus discursos muito bons para aquela época - de fato, revelavam certo engenho, mas bastante grosseiro e extremamente rude -, mas quando dizia que suas Origines [Origens] estão repletas de todas as qualidades oratórias e comparavas Catão a Filisto e Tucídides, acaso não acreditava que você tinha demonstrado isso a Bruto ou a mim? Aqueles que nem mesmo entre os gregos alguém pode imitar, a eles você compara um homem de Túsculo que nem mesmo imaginava o que era discursar de modo copioso e ornado.

[295] Você elogia Galba. Se comparado aos de sua época, concordo que era o primeiro - assim nos foi transmitido —; mas 
ut oratorem, cedo quaeso orationes - sunt enim - et dic hunc, quem tu plus quam te amas, Brutum uelle te illo modo dicere. probas Lepidi orationes. paulum hic tibi adsentior, modo ita laudes ut antiquas; quod item de Africano, de Laelio, cuius tu oratione negas fieri quicquam posse dulcius, addis etiam nescio quid augustius. nomine nos capis summi uiri uitaeque elegantissumae uerissimis laudibus. remoue haec: ne ista dulcis oratio ita sit abiecta ut eam aspicere nemo uelit. (296) Carbonem in summis oratoribus habitum scio; sed cum in ceteris rebus tum in dicendo semper, quo iam nihil est melius, id laudari qualecumque est solet. dico idem de Gracchis, etsi de eis ea sunt a te dicta, quibus ego adsentior. omitto ceteros; uenio ad eos in quibus iam perfectam putas esse eloquentiam, quos ego audiui sine controuersia magnos oratores, Crassum et Antonium. de horum laudibus tibi prorsus adsentior, sed tamen non isto modo: ut Polycliti doryphorum sibi Lysippus aiebat, sic tu suasionem legis Seruiliae tibi magistram fuisse; haec germana ironia est. cur ita sentiam non dicam, ne me tibi adsentari putes. (297) Omitto igitur quae de his ipsis, quae de Cotta, quae de Sulpicio, quae modo de Caelio dixeris. hi enim fuerunt certe oratores; quanti autem et quales tu uideris. nam illud minus curo, quod se foi um verdadeiro orador, mostre-me, então, seus discursos - de fato, existem - e diga-me se deseja que Bruto, este que você preza mais que a você mesmo, discurse daquela maneira. Você louva os discursos de Lépido. Nisso concordo em parte, enquanto o elogia pela sua antiguidade, o mesmo em ralação a Africano, a Lélio, sobre cuja oratória você afirma que ninguém pode ser mais agradável e ainda acrescenta um não sei que de "augusto". Você nos cativa com o nome de um grande homem e com as justíssimas honras de uma vida muito distinta. Deixe isso de lado: para que esse agradável discurso não seja tão abjeto que ninguém queira dar atenção. [296] Sei que Carbão é colocado entre os melhores oradores, mas tanto nos demais assuntos como na oratória sempre se costuma louvar aquilo de que não há nada melhor. Digo o mesmo sobre os Graco, embora sobre eles você tenha dito coisas com as quais concordo. Deixo os outros de lado, venho àqueles nos quais você considera que há uma eloquência perfeita, os quais eu mesmo ouvi, sem dúvida grandes oradores, Crasso e Antônio. Concordo plenamente com você em relação aos seus méritos, embora não no seguinte modo: tal como Lisipo dizia que foi para ele o Doriforo de Policleto, assim também para você foi um mestre o discurso em favor da lei Servília, isso é uma verdadeira ironia. Não direi por que penso assim, para que não pense que eu esteja lhe adulando. [297] Portanto, deixo de lado aquilo que tens dito acerca deles, acerca de Cota, acerca 
congessisti operarios omnes; ut mihi uideantur mori uoluisse nonnulli, ut a te in oratorum numerum referrentur. [87] LXXXVII. Haec cum ille dixisset: longi sermonis initium pepulisti, inquam, Attice, remque commouisti noua disputatione dignam, quam in aliud tempus differamus. (298) Voluendi enim sunt libri cum aliorum tum in primis Catonis. intelleges nihil illius liniamentis nisi eorum pigmentorum, quae inuenta nondum erant, florem et colorem defuisse. nam de Crassi oratione sic existumo, ipsum fortasse melius potuisse scribere, alium, ut arbitror, neminem. nec in hoc g-eirohna me duxeris esse, quod eam orationem mihi magistram fuisse dixerim. nam etsi (ut) tu melius existumare uideris de ea, si quam nunc habemus, facultate, tamen adulescentes quid in Latinis potius imitaremur non habebamus.

(299) Quod autem plures a nobis nominati sunt, eo pertinuit, ut paulo ante dixi, quod intellegi uolui, in eo, cuius omnes cupidissimi essent, quam pauci digni nomine euaderent. quare g-eirohna me, ne si Africanus quidem fuit, ut ait in historia sua de Sulpício, também acerca de Célio. Com efeito, eles realmente foram oradores, mas cuja grandeza e qualidade você tem de avaliar. De fato, preocupa-me menos o fato de que você recolheste todos os operários da eloquência; parece-me que alguns deles teriam desejado morrer para que fossem incluídos por você na categoria dos oradores. Como ele tivesse dito isso, respondi: - Você deu início, Ático, a uma longa discussão e levantou uma questão digna de uma nova controvérsia, que deixaremos para um outro momento. [298] Com efeito, devem ser lidos não apenas os livros de muitos outros mas principalmente os de Catão. Você compreenderá que em seu traço nada faltou a não ser o floreio e o colorido daquela pigmentação que ainda não havia sido inventada. De fato, acerca do discurso de Crasso penso o seguinte: ele mesmo talvez pudesse ter escrito melhor, na minha opinião, ninguém mais. E você não pode me considerar um irônico (in hoc $\varepsilon$ ' $(p \omega \nu \alpha)$ pelo fato de eu ter dito que esse discurso foi para mim um mestre. De fato, embora me pareça que você estima mais essa capacidade, se é que hoje a possuo, no entanto em minha juventude eu não possuía entre os latinos alguém melhor para imitar.

[299] Quanto ao fato de eu ter mencionado o nome de muitos, tinha como propósito, como disse há pouco, que se compreendesse que nesse grupo ao qual todos desejam petencer, quão poucos foram dignos de menção. Por isso, não gostaria de ser considerado irônico ( $\varepsilon$ 'ip $\omega \nu \alpha)$, mesmo 
C. Fannius, existumari uelim. Ut uoles, inquit Atticus. ego enim non alienum a te putabam quod et in Africano fuisset et in Socrate. (300) Tum Brutus: de isto postea; sed tu, inquit me intuens, orationes nobis ueteres explicabis? Vero, inquam, Brute; sed in Cumano aut in Tusculano aliquando, si modo licebit, quoniam utroque in loco uicini sumus. [88] LXXXVIII. Sed iam ad id, unde digressi sumus, reuertamur. (301) Hortensius igitur cum admodum adulescens orsus esset in foro dicere, celeriter ad maiores causas adhiberi coeptus est; et quamquam inciderat in Cottae et Sulpici aetatem, qui annis decem maiores erant, excellente tum Crasso et Antonio, dein Philippo, post Iulio, cum his ipsis dicendi gloria comparabatur. primum memoria tanta, quantam in nullo cognouisse me arbitror, ut quae secum commentatus esset, ea sine scripto uerbis eisdem redderet, quibus cogitauisset. hoc adiumento ille tanto sic utebatur, ut sua et commentata et scripta et nullo referente omnia aduersariorum dicta meminisset. (302) Ardebat autem cupiditate sic, ut in nullo umquam flagrantius studium uiderim. nullum enim patiebatur esse diem quin aut in foro diceret aut meditaretur extra forum. saepissume autem eodem die utrumque faciebat. adtuleratque minime uolgare genus dicendi; duas quidem que Africano o tenha sido, como Caio Fânio relata em sua história. - Como você quiser, retrucou Ático. Com efeito, eu não achava que lhe fosse alheio aquilo que pertencia tanto a Africano como a Sócrates. [300] Bruto, então: - Disso falamos depois. Você, porém, perguntou olhando para mim, vais nos relatar os discursos antigos? - É claro, Bruto, respondi, mas em alguma outra ocasião em Cumano ou em Túsculo, se realmente for possível, já que somos vizinhos em ambas as localidades. Mas já é hora de voltarmos ao ponto onde fizemos a digressão. [301] Hortênsio, então, depois de começar a discursar no fórum muito jovem, rapidamente passou a defender as causas mais importantes. E embora tivesse vivido na época de Cota e Sulpício, que eram dez anos mais velhos que ele, sendo então os melhores Crasso e Antônio, em seguida Filipo, depois Júlio, com eles era comparado na glória oratória. Em primeiro lugar, de uma memória tamanha que creio jamais tê-la encontrado em mais ninguém, de modo que aquilo que havia meditado ele conseguia repetir sem escrito nos mesmos termos com os quais havia cogitado. Ele se utilizava tanto desse auxílio que era capaz de lembrar não só daquilo que havia elaborado e escrito como também de tudo que fora dito pelos adversários sem qualquer relato escrito. [302] E ardia de tanta ambição que eu nunca tinha visto em ninguém um zelo mais fervoroso. Com efeito, não passava nenhum dia sem que ou discursasse no fórum ou estivesse meditando extra fórum. 
res quas nemo alius: partitiones, quibus de rebus dicturus esset, et conlectiones, memor et quae essent dicta contra quaeque ipse dixisset. (303) Erat in uerborum splendore elegans, compositione aptus, facultate copiosus; eaque erat cum summo ingenio tum exercitationibus maxumis consecutus. rem complectebatur memoriter, diuidebat acute, nec praetermittebat fere quicquam, quod esset in causa aut ad confirmandum aut ad refellendum. uox canora et suauis, motus et gestus etiam plus artis habebat quam erat oratori satis. hoc igitur florescente Crassus est mortuus, Cotta pulsus, iudicia intermissa bello, nos in forum uenimus.

[89] LXXXIX. (304) Erat Hortensius in bello primo anno miles, altero tribunus militum, Sulpicius legatus; aberat etiam M. Antonius; exercebatur una lege iudicium Varia, ceteris propter bellum intermissis; quoi frequens aderam, quamquam pro se ipsi dicebant oratores non illi quidem principes, L. Memmius et Q. Pompeius, sed oratores tamen teste diserto uterque Philippo, cuius in testimonio contentio et uim accusatoris habebat et copiam. (305) Reliqui qui tum principes numerabantur in
Mas frequentemente fazia ambas as coisas no mesmo dia. E havia introduzido um gênero oratório nada usual. Duas coisas realmente diferenciavam-no dos outros: as divisões, sobre as quais os argumentos hão de ser apresentados, e as recapitulações, memória tanto do que foi dito pela parte contrária como do que ele mesmo havia dito. [303] Era brilhante na escolha das palavras, coerente na disposição, pleno de expressividade e havia conseguido isso não apenas pelo excelente engenho mas também com muitíssimos exercícios oratórios. Abarcava toda a matéria na memória, dividia com agudeza e não deixava de lado nada inerente à causa que pudesse fornecer ou a confirmação ou a refutação. Possuía uma voz harmoniosa e doce, movimento e gesto com habilidade bem maior do que era necessário a um orador. Então, quando sua eloquência florescia, Crasso morreu, Cota foi exilado, os tribunais suspensos pela guerra, eu cheguei ao fórum.

[304] Hortênsio era soldado no primeiro ano da guerra, no seguinte tribuno militar, Sulpício era legado; também estava ausente Marco Antônio; os processos legais eram exercidos com base unicamente na lei Vária, os demais foram suspensos por causa da guerra; aos quais com frequência estive presente, embora discursassem em sua própria defesa não aqueles oradores de primeira linha, e sim Lúcio Mêmio e Quinto Pompeu, mas, no entanto, ambos eram oradores, um eloquente testemunho foi Filipo, cuja violenta deposição continha tanto a força como a abundância de 
magistratibus erant cotidieque fere a nobis in contionibus audiebantur. erat enim tribunus plebis tum $\mathrm{C}$. $\mathrm{Cu}-$ rio, quamquam is quidem silebat, ut erat semel a contione uniuersa relictus; Q. Metellus Celer non ille quidem orator sed tamen non infans; diserti autem Q. Varius C. Carbo Cn. Pomponius, et hi quidem habitabant in rostris; C. etiam Iulius aedilis curulis cotidie fere accuratas contiones habebat. sed me cupidissumum audiendi primus dolor percussit, Cotta cum est expulsus. reliquos frequenter audiens acerrumo studio tenebar cotidieque et scribens et legens et commentans oratoriis tantum exercitationibus contentus non eram. iam consequente anno Q. Varius sua lege damnatus excesserat. (306) Ego autem iuris ciuilis studio multum operae dabam Q. Scaeuolae P. f., qui quamquam nemini se ad docendum dabat, tamen consulentibus respondendo studiosos audiendi docebat. atque huic anno proxumus Sulla consule et Pompeio fuit. tum P. Sulpici in tribunatu cotidie contionantis totum genus dicendi penitus cognouimus; eodemque tempore, cum princeps Academiae Philo cum Atheniensium optumatibus Mithridatico bello domo profugisset Romamque uenisset, totum ei me tradidi admirabili quodam ad philosophiam studio concitatus; in quo hoc etiam commorabar adtentius - etsi rerum ipsa- um acusador. [305] Os demais que então estavam entre os primeiros ocupavam as magistraturas, e quase diariamente eu escutava os discursos nas assembleias. Com efeito, o então tribuno da plebe era Caio Cúrio, embora ele, na verdade, guardasse silêncio, depois de ter sido uma vez abandonado por toda assembleia. Quinto Metelo Celero não era propriamente um orador mas, no entanto, não desarticulado. Bem articulados, porém, eram Quinto Vário, Caio Carbo, Gneu Pompônio, e eles realmente viviam na tribuna. Caio Júlio, edil currul, também quase diariamente discursava nas assembleias com diligência. Mas, muito empenhado em ouvir, a primeira dor me abateu, quando Cota foi exilado. Ouvindo amiúde os outros, empenhava-me fortemente no estudo e diariamente não só escrevia mas também lia, bem como praticava, mas os exercícios oratórios apenas não me satisfaziam. Já no ano seguinte, Quinto Vário, condenado pela sua própria lei, havia deixado a cidade. [306] $\mathrm{Eu}$, porém, muito me empenhava no estudo do direito civil com Quinto Cévola, filho de Públio, que, embora não se prestasse a ensinar ninguém, todavia, ao responder àqueles que o consultavam, ensinava aos que se prestavam a ouvi-lo. E no ano que se seguiu foram cônsules Sila e Pompeu. Então pude conhecer plenamente o gênero de eloquência de Públio Sulpício, em cujo tribunado discursava diariamente na assembleia; na mesma época em que Filo, escolarca da Academia, fugiu de sua pátria com os aristocratas atenien- 
rum uarietas et magnitudo summa me delectatione retinebat — , sed tamen sublata iam esse in perpetuum ratio iudiciorum uidebatur.

(307) Occiderat Sulpicius illo anno tresque proxumo trium aetatum oratores erant crudelissume interfecti, Q- Catulus M- Antonius CIulius. eodem anno etiam Moloni Rhodio Romae dedimus operam et actori summo causarum et magistro. [90] XC. Haec etsi uidentur esse a proposita ratione diuersa, tamen idcirco a me proferuntur, ut nostrum cursum perspicere, quoniam uoluisti, Brute, possis - nam Attico haec nota sunt - et uidere quem ad modum simus in spatio Q. Hortensium ipsius uestigiis persecuti. (308) Triennium fere fuit urbs sine armis; sed oratorum aut interitu aut discessu aut fuga - nam aberant etiam adulescentes M. Crassus et Lentuli duo - primas in causis agebat Hortensius, magis magisque cotidie probabatur Antistius, Piso saepe dicebat, minus saepe Pomponius, raro Carbo, semel aut iterum Philippus. at uero ego hoc tempore omni noctes et dies in omnium doctrinarum meditatione uersabar. (309) Eram cum Stoico Diodoto, qui cum habitauisset apud me ses em razão da guerra mitridata e chegou em Roma, dediquei-me inteiramente a ele, incitado por um desejo admirável pela filosofia; nisso eu me detinha com muito zelo - embora a extrema variedade e grandeza dos próprios argumentos me cativassem pelo prazer -, mas, no entanto, o funcionamento dos tribunais parecia ter sido suprimido para sempre.

[307] Sulpício havia morrido naquele ano, e no ano seguinte três oradores de três gerações haviam sido cruelmente mortos, Quinto Cátulo, Marco Antônio e Caio Júlio. No mesmo ano, em Roma, frequentei Molon de Rodes, excelente não só como defensor de causas mas também como mestre. Essas coisas, embora pareçam estar distantes do argumento inicial, todavia as menciono para que você possa, já que você pediu, conhecer minha carreira - com efeito, Ático sabe disso - e ver de que modo segui nesse caminho os passos do próprio Hortênsio. [308] Durante quase três anos a cidade esteve livre das armas, mas ou em razão da morte ou do afastamento ou do exílio dos oradores - de fato, estavam ausentes os jovens Marco Crasso e os dois Lêntulos - Hortênsio atuava nas principais causas, e Antístio a cada dia era mais apreciado, Pisão discursava amiúde, menos frequentemente Pompônio, raramente Carbão, uma ou duas vezes Filipo. Eu, por outro lado, na mesma época, todos os dias e noites me ocupava com o estudo de todas as doutrinas. [309] Convivia com o estóico Diodoto, que depois de ter morado e vivido comigo, morreu em minha 
se cumque uixisset, nuper est domi meae mortuus. a quo cum in aliis rebus tum studiosissime in dialectica exercebar, quae quasi contracta et astricta eloquentia putanda est; sine qua etiam tu, Brute, iudicauisti te illam iustam eloquentiam, quam dialecticam esse dilatatam putant, consequi non posse. huic ego doctori et eius artibus uariis atque multis ita eram tamen deditus ut ab exercitationibus oratoriis nullus dies uacuus esset. (310) Commentabar declamitans — sic enim nunc loquuntur - saepe cum M. Pisone et cum Q. Pompeio aut cum aliquo cotidie, idque faciebam multum etiam Latine sed Graece saepius, uel quod Graeca oratio plura ornamenta suppeditans consuetudinem similiter Latine dicendi adferebat, uel quod a Graecis summis doctoribus, nisi Graece dicerem, neque corrigi possem neque doceri. (311) Tumultus interim recuperanda re publica et crudelis interitus oratorum trium, Scaeuolae Carbonis Antisti, reditus Cottae Curionis Crassi Lentulorum Pompei; leges et iudicia constituta, recuperata res publica; ex numero autem oratorum Pomponius Censorinus Murena sublati. tum primum nos ad causas et priuatas et publicas adire coepimus, non ut in foro disceremus, quod plerique fecerunt, sed ut, quantum nos efficere potuissemus, docti in forum ueniremus. (312) Eodem tempore casa há pouco tempo. Com quem eu me exercitava não apenas nos demais assuntos mas sobretudo na dialética, que deve ser considerada, por assim dizer, uma eloquência contrata e cerrada, sem a qual também você, Bruto, tem considerado que não se pode alcançar a legítima eloquência, que consideram como sendo uma dialética ampliada. A esse mestre e a seus vários e múltiplos conhecimentos eu me dedicava tanto, mas sem jamais me privar dos exercícios oratórios. [310] Preparava-me declamando - assim chamam hoje em dia - no mais das vezes com Marco Pisão e com Quinto Pompeu ou com algum outro a cada dia, o que eu fazia bastante também em latim mas com mais frequência em grego, ou porque a língua grega, fornecendo uma pluralidade de ornamentos, produzia o hábito de discursar em latim de modo semelhante, ou porque, se não discursasse em grego, não poderia ser auxiliado nem ser educado pelos melhores mestres gregos. [311] Entretanto, houve mais hostilidades na restauração da república e a morte cruel de três oradores, Cévola, Carbão e Antístio, o retorno de Cota, de Curião, de Crasso, dos Lêntulos, de Pompeu; o restabelecimento das leis e dos tribunais, a república restaurada; removidos da categoria dos orades Pompônio, Censorino e Murena. Então, foi quando comecei a tomar parte tanto nos processos privados como nos públicos, não para que aprendesse no fórum, como muitos fizeram, mas para que, o quanto me fosse possível, chegasse ao fórum já instruído. [312] Na mesma época, segui 
Moloni dedimus operam; dictatore enim Sulla legatus ad senatum de Rhodiorum praemiis uenerat. itaque prima causa publica pro Sex. Roscio dicta tantum commendationis habuit, ut non ulla esset quae non digna nostro patrocinio uideretur. deinceps inde multae, quas nos diligenter elaboratas et tamquam elucubratas adferebamus.

[91] XCI. (313) Nunc quoniam totum me non naeuo aliquo aut crepundiis sed corpore omni uideris uelle cognoscere, complectar nonnulla etiam quae fortasse uideantur minus necessaria. erat eo tempore in nobis summa gracilitas et infirmitas corporis, procerum et tenue collum: qui habitus et quae figura non procul abesse putatur a uitae periculo, si accedit labor et laterum magna contentio. eoque magis hoc eos quibus eram carus commouebat, quod omnia sine remissione, sine uarietate, ui summa uocis et totius corporis contentione dicebam. (314) Itaque cum me et amici et medici hortarentur ut causas agere desisterem, quoduis potius periculum mihi adeundum quam a sperata dicendi gloria discedendum putaui. sed cum censerem remissione et moderatione uocis et commutato genere dicendi me et periculum uitare posse et temperatius dicere, ut consuetudinem dicendi mutarem, ea causa mihi in Asiam proficiscendi as lições de Mólon, pois durante a ditadura de Sila ele viera como embaixador ao senado a fim de negociar as recompensas para os rodienses. Por isso, meu primeiro processo público, discurso em defesa de Sexto Róscio, obteve tanta aprovação que não havia nenhum que não parecesse digno de meu patrocínio. Em seguida, a partir de então, eu cuidava de muitos processos, os quais eram cuidadosamente elaborados e, por assim dizer, elucubrados.

[313] Agora, já que parece querer me conhecer por completo, não por alguma marca de nascimento ou colarinho infantil, mas sim por toda minha compleição, incluirei ainda algumas coisas que talvez pareçam menos necessárias. Eu tinha, naquela época, um corpo extremamente magro e fraco, um pescoço alongado e delgado, com esse aspecto e com essa aparência estimase não estar muito longe de uma vida de perigos, se ainda se acrescenta a fadiga e o extremo esforço dos pulmões. Isso preocupava ainda mais aqueles que me tinham em boa conta, porque eu conduzia todo meu discurso sem diminuir a intensidade, sem variar no tom, com extrema força na voz e tensão em todo corpo. [314] Por isso, enquanto meus amigos e os médicos aconselhavam-me a desistir de atuar como orador, eu pensava que deveria antes enfrentar qualquer perigo do que abandonar a desejada glória oratória. Mas como eu julgava que pela diminuição da intensidade e moderação da voz e pela mudança do gênero oratório eu poderia evitar o perigo e discursar com mais equilíbrio, a fim de 
fuit. itaque cum essem biennium uersatus in causis et iam in foro celebratum meum nomen esset, Roma sum profectus. (315) Cum uenissem Athenas, sex menses cum Antiocho ueteris Academiae nobilissumo et prudentissumo philosopho fui studiumque philosophiae numquam intermissum a primaque adulescentia cultum et semper auctum hoc rursus summo auctore et doctore renouaui. eodem tamen tempore Athenis apud Demetrium Syrum ueterem et non ignobilem dicendi magistrum studiose exerceri solebam. post a me Asia tota peragrata est cum summis quidem oratoribus, quibuscum exercebar ipsis lubentibus; quorum erat princeps Menippus Stratonicensis meo iudicio tota Asia illis temporibus disertissimus; et, si nihil habere molestiarum nec ineptia rum Atticorum est, hic orator in illis numerari recte potest. (316) adsiduissime autem mecum fuit Dionysius Magnes; erat etiam Aeschylus Cnidius, Adramyttenus Xenocles. hi tum in Asia rhetorum principes numerabantur. quibus non contentus Rhodum ueni meque ad eundem quem Romae audiueram Molonem adplicaui cum actorem in ueris causis scriptoremque praestantem tum in notandis animaduertendisque uitiis et instituendo docendoque prudentissimum. is dedit operam, si modo id consequi potuit, ut nimis redundantis nos mudar meu modo de discursar, essa foi a causa de minha partida para a Ásia. Por isso, depois de me ocupar das causas por dois anos e já ter meu nome celebrado no fórum, deixei Roma. [315] Quando cheguei a Atenas, estive seis meses com Antíoco, o mais renomado e mais sábio filósofo da velha Academia, e com esse excelente guia e mestre retomei o estudo nunca interrompido da filosofia, cultivado e sempre incrementado desde minha primeira juventude. Entretanto, na mesma época, costumava me dedicar a exercícios com Demétrio Sírio, um velho e não desconhecido mestre de eloquência. Depois percorri toda Ásia com grandes oradores, que de bom grado orientavam meus exercícios, dos quais o primeiro era Menipo de Estratoniceia, a meu ver o mais hábil de toda Ásia daquela época; e, se é próprio dos áticos não conter nada de inadequado nem de afetado, certamente este orador pode ser incluído entre eles. [316] E esteve junto a mim com mais frequência Dionísio de Magnésia, havia também Ésquilo de Cnido e Xênocles de Adramita. Eles eram, então, considerados na Ásia os rétores mais importantes. Não me contentando com eles, fui a Rodes e acompanhei o mesmo Mólon que eu havia ouvido em Roma, ele não só escrevia e atuava em causas reais mas também era muito sábio em perceber e censurar os vícios bem como para instruir e ensinar. Ele se dedicou, se é que conseguiu fazê-lo, a refrear a exuberância excessiva e transbordante de meu discurso, dotado de certa liberdade e licença juvenil, e a conter, por assim dizer, 
et supra fluentis iuuenili quadam dicendi impunitate et licentia reprimeret et quasi extra ripas diffluentis coerceret. ita recepi me biennio post non modo exercitatior sed prope mutatus. nam et contentio nimia uocis resederat et quasi deferuerat oratio lateribusque uires et corpori mediocris habitus accesserat.

[92] XCII. (317) Duo tum excellebant oratores qui me imitandi cupiditate incitarent, Cotta et Hortensius; quorum alter remissus et lenis et propriis uerbis comprendens solute et facile sententiam, alter ornatus, acer et non talis qualem tu eum, Brute, iam deflorescentem cognouisti, sed uerborum et actionis genere commotior. itaque cum Hortensio mihi magis arbitrabar rem esse, quod et dicendi ardore eram propior et aetate coniunctior. etenim uideram in isdem causis, ut pro M. Canuleio, pro Cn. Dolabella consulari, cum Cotta princeps adhibitus esset, priores tamen agere partis Hortensium. acrem enim oratorem, incensum et agentem et canorum concursus hominum forique strepitus desiderat. (318) Unum igitur annum, cum redissemus ex Asia, causas nobilis egimus, cum quaesturam nos, consulatum Cotta, aedilitatem peteret Hortensius. interim me quaestorem Siciliensis excepit annus, Cotta ex consulatu est profectus in Galliam, princeps et erat et habebatur Hortensius. cum autem anno o fluxo que excedia as margens. Assim, dois anos depois, retornei não apenas mais exercitado, mas quase transformado. Com efeito, diminuíra a excessiva tensão da voz, meu discurso como que arrefecera, meus pulmões se fortaleceram, e meu corpo ganhara uma compleição razoável.

[317] Os dois melhores oradores do momento, que me incitavam o desejo de imitálos, eram Cota e Hortênsio, dos quais o primeiro, tranquilo e brando, formulava os argumentos com termos apropriados de modo fluente e desembaraçado, o segundo, ornamentado e impetuoso, não como você o conheceu, Bruto, quando já estava perdendo o viço, porém seu discurso era mais veemente nas palavras e na atuação. Por isso, parecia-me que a disputa se dava sobretudo com Hortênsio, porque a mim mais se adequava seu ímpeto oratório e a proximidade da idade. E, de fato, havia visto ambos nas mesmas causas, como nas defesas de Marco Canuleio e do cônsul Gneu Dolabela, embora Cota tivesse sido colocado como principal orador, as partes mais importantes, porém, ficaram com Hortênsio. De fato, a multidão das assembleias e o alarido do fórum exigem um orador enérgico, inflamado, de atuação vivaz e voz sonora. [318] Então, depois de ter retornado da Ásia, atuei durante um ano em importantes causas, quando me candidatei à questura, Cota ao consulado, Hortênsio à edilidade. Nesse meio tempo, no ano que sucedeu minha questura na Sicília, depois 
post ex Sicilia me recepissem, iam uidebatur illud in me, quicquid esset, esse perfectum et habere maturitatem quandam suam. nimis multa uideor de me, ipse praesertim; sed omni huic sermoni propositum est, non ut ingenium et eloquentiam meam perspicias, unde longe absum, sed ut laborem et industriam.

(319) Cum igitur essem in plurumis causis et in principibus patronis quinquennium fere uersatus, tum in patrocinio Siciliensi maxume in certamen ueni designatus aedilis cum designato consule Hortensio. [93] XCIII. Sed quoniam omnis hic sermo noster non solum enumerationem oratoriam uerum etiam praecepta quaedam desiderat, quid tamquam notandum et animaduertendum sit in Hortensio breuiter licet dicere. (320) Nam is post consulatum - credo quod uideret ex consularibus neminem esse secum comparandum, neglegeret autem eos qui consules non fuissent - summum illud suum studium remisit, quo a puero fuerat incensus, atque in omnium rerum abundantia uoluit beatius, ut ipse putabat, remissius certe uivere. primus et secundus annus et tertius tantum quasi de picturae ueteris colore detraxerat, quantum non quiuis unus ex populo, sed existuma- do consulado, Cota partiu para a Gália, Hortênsio não só era, de fato, o principal orador, mas também era considerado como tal. Porém, um ano depois quando retornei da Sicília, já parecia que algo em mim, o que quer que fosse, havia se completado e adquirido como que sua maturidade. Acho que falei demais sobre mim, até porque sou eu quem falo; mas o propósito de todo esse discurso é que perceba claramente não o meu engenho e eloquência, estou longe disso, mas o meu esforço e empenho.

[319] Pois bem, depois de ter atuado em diversas causas por quase cinco anos e estado entre os principais patronos, então em defesa dos sicilianos fui designado edil exatamente na disputa com o cônsul designado Hortênsio. Mas, já que toda esta nossa conversa requer não apenas uma enumeração de oradores, mas também certos preceitos, é lícito dizer brevemente aquilo que, por assim dizer, deve ser percebido e censurado em Hortênsio. [320] Com efeito, depois do consulado - creio que vendo que nenhum dos anteriores cônsules pudesse ser comparado a ele, negligenciando, porém, aqueles que não haviam sido cônsules -, abandonou aquele seu extraordinário empenho, que o inflamara desde criança, e almejava levar uma vida mais tranquila em meio a sua grande riqueza, como ele acreditava, mas na verdade menos ativa. O primeiro, o segundo e o terceiro ano haviam, por assim dizer, desbotado a cor de uma velha pintura numa tal proporção que ninguém do povo era capaz de perceber, mas apenas um crítico instruído e competente. Porém, 
tor doctus et intellegens posset cognoscere. longius autem procedens ut in ceteris eloquentiae partibus, tum maxume in celeritate et continuatione uerborum adhaerescens, sui dissimilior uidebatur fieri cotidie. (321) Nos autem non desistebamus cum omni genere exercitationis tum maxume stilo nostrum illud quod erat augere, quantumcumque erat. atque ut multa omittam in hoc spatio et in his post aedilitatem annis, et praetor primus et incredibili populari uoluntate sum factus. nam cum propter adsiduitatem in causis et industriam tum propter exquisitius et minime uolgare orationis genus animos hominum ad me dicendi nouitate conuerteram. (322) Nihil de me dicam: dicam de ceteris, quorum nemo erat qui uideretur exquisitius quam uolgus hominum studuisse litteris, quibus fons perfectae eloquentiae continetur; nemo qui philosophiam complexus esset matrem omnium bene factorum beneque dictorum; nemo qui ius ciuile didicisset rem ad priuatas causas et ad oratoris prudentiam maxume necessariam; nemo qui memoriam rerum Romanarum teneret, ex qua, si quando opus esset, ab inferis locupletissimos testes excitaret; nemo qui breuiter arguteque incluso aduersario laxaret iudicum animos atque a seueritate paulisper ad hilaritatem risumque traduceret; nemo qui dilatare posset atque a pro- com o passar do tempo, degenerando tanto nas demais partes de sua eloquência, mas principalmente na velocidade e no encadeamento das palavras, parecia se tornar a cada dia mais diferente de si mesmo. [321] Mas eu não deixava de aumentar, não só com todo tipo de exercício, mas sobretudo com a escrita, aquilo que havia em mim, o que quer que fosse. E, deixando de lado algumas coisas desse período e dos anos posteriores à edilidade, fui eleito pretor com maioria de votos e incrível apoio popular. De fato, não apenas em razão de minha assiduidade e diligência nas causas, mas também em razão de uma eloquência mais refinada e nada vulgar, eu havia atraído as atenções para mim pela novidade de meu discurso. [322] Não direi nada sobre mim, direi sobre os outros, dos quais não havia ninguém que parecesse mais empenhado do que a maioria dos homens no estudo das letras, nas quais está contida a fonte de uma eloquência plena; ninguém cuja formação abarcasse a filosofia, mãe de todo bem agir e bem dizer; ninguém que tivesse aprendido direito civil, o que é extremamente necessário para as causas privadas e para o conhecimento prático do orador; ninguém que conhecesse a história romana, da qual, quando necessário, podem ser evocados riquíssimos testemunhos dos mortos; ninguém que, tendo encurralado o adversário, com uma argumentação breve e precisa pudesse abrandar os ânimos dos juízes e conduzi-los num instante da seriedade à alegria e ao riso; ninguém que fossse capaz de ampliar um discurso 
pria ac definita disputatione hominis ac temporis ad communem quaestionem uniuersi generis orationem traducere; nemo qui delectandi gratia digredi parumper a causa, nemo qui ad iracundiam magno opere iudicem, nemo qui ad fletum posset adducere, nemo qui animum eius, quod unum est oratoris maxume proprium, quocumque res postularet impellere.

[94] XCIV. (323) Itaque cum iam paene euanuisset Hortensius et ego anno meo, sexto autem post illum consulem, consul factus essem, reuocare se ad industriam coepit, ne, cum pares honore essemus, aliqua re superiores uideremur. sic duodecim post meum consulatum annos in maxumis causis, cum ego mihi illum, sibi me ille anteferret, coniunctissime uersati sumus, consulatusque meus, qui illum primo leuiter perstrinxerat, idem nos rerum mearum gestarum, quas ille admirabatur, laude coniunxerat. (324) Maxume uero perspecta est utriusque nostrum exercitatio paulo ante quam perterritum armis hoc studium, Brute, nostrum conticuit subito et obmutuit: cum lege Pompeia ternis horis ad dicendum datis ad causas simillumas inter se uel potius easdem noui ueniebamus cotidie. quibus quidem causis tu etiam, Brute, praesto fuisti complurisque et nobiscum et solus egisti, ut qui non satis diu uixerit Hortensius tamen hunc cursum confecerit: e a partir de uma discussão particular e definida, restrita a uma pessoa e circunstância, convertê-la numa questão geral e universal; ninguém que para deleitar faça uma breve digressão; ninguém que fosse capaz de conduzir fortemente o juiz à irascibilidade, ninguém ao riso; ninguém capaz de provocar no ânimo do juiz — o que é a principal característica do orador - o que quer que o caso exija.

[323] Por isso, quando Hortênsio já havia quase desvanecido, e eu, na idade prevista, seis anos depois de seu consulado, havia sido eleito cônsul, ele começou a retomar sua atividade, para que eu não lhe parecesse superior em alguma coisa, já que nos igualávamos na honra consular. Assim, durante doze anos depois de meu consulado, atuamos juntos em importantíssimas causas, nas quais eu dava a ele a precedência e ele, a mim, e meu próprio consulado, que primeiramente $o$ ofendera um pouco, nos unira pelo elogio de meus feitos, os quais ele admirava. [324] Mas nossa maestria mútua melhor se manifestou pouco antes dessa nossa atividade, Bruto, aterrorizada pelas armas, subitamente ter silenciado e emudecido: quando a lei pompeia restringiu a três horas a fala de cada orador, em causas semelhantes entre si ou mesmo iguais, parecíamos renovados a cada dia. Causas em que você também, Bruto, esteve presente e em algumas delas você atuou tanto comigo como sozinho, e ainda que Hortênsio não tenha vivido muito, todavia conseguiu completar sua carreira: começou a atuar nas causas 
annis ante decem causas agere coepit quam tu es natus; idem quarto et sexagensumo anno, perpaucis ante mortem diebus, una tecum socerum tuum defendit Appium. dicendi autem genus quod fuerit in utroque, orationes utriusque etiam posteris nostris indicabunt.

[95] XCV. (325) Sed si quaerimus, cur adulescens magis floruerit dicendo quam senior Hortensius, causas reperiemus uerissumas duas. primum, quod genus erat orationis Asiaticum adulescentiae magis concessum quam senectuti. genera autem Asiaticae dictionis duo sunt: unum sententiosum et argutum, sententiis non tam grauibus et seueris quam concinnis et uenustis, qualis in historia Timaeus, in dicendo autem pueris nobis Hierocles Alabandeus, magis etiam Menecles frater eius fuit, quorum utriusque orationes sunt in primis ut Asiatico in genere laudabiles. aliud autem genus est non tam sententiis frequentatum quam uerbis uolucre atque incitatum, quali est nunc Asia tota, nec flumine solum orationis sed etiam exornato et faceto genere uerborum, in quo fuit Aeschylus Cnidius et meus aequalis Milesius Aeschines. in his erat admirabilis orationis cursus, ornata sententiarum concinnitas non erat. (326) Haec autem, ut dixi, genera dicendi aptiora sunt adulescentibus, in senibus grauitatem non habent. ita- dez anos antes de você ter nascido; e exatamente aos sessenta e quatro anos, poucos dias antes de morrer, atuou contigo na defesa de seu sogro Ápio. Mas qual teria sido o gênero oratório de cada um de nós, os discursos de ambos revelarão também à posteridade.

[325] Mas se procurarmos por que razão a eloquência de Hortênsio floresceu mais na juventude do que na velhice, descobriremos dois verdadeiros motivos. O primeiro: pelo fato de o gênero oratório asiático ser mais adequado à juventude do que à maturidade. São dois, porém, os gêneros de eloquência asiáticos: um sentencioso e penetrante, com argumentos não tão elevados e sisudos, mas harmoniosos e elegantes, tal como na história de Timeu, na oratória de Hiérocles de Alabanda, na minha infância, e ainda mais na de seu irmão Mênecles, os discursos de ambos estão entre os mais louváveis do gênero asiático. O outro gênero, porém, não é tão provido de argumentos quanto impetuoso e veloz nas palavras, tal como predomina hoje na Ásia, nem caracterizado somente pelo grande fluxo do discurso mas também pela elocução bem ornada e espirituosa, no qual estão incluídos Ésquilo de Cnidio e meu contemporâneo Ésquines de Mileto. Era admirável neles o andamento do discurso, não havia uma argumentação bem arranjada e ornamentada. [326] Mas, como eu disse, esses gêneros oratórios são mais apropriados aos jovens, entre os mais velhos não possuem peso. Por isso, Hortênsio, brilhando em 
que Hortensius utroque genere florens clamores faciebat adulescens. habebat enim et Meneclium illud studium crebrarum uenustarumque sententiarum, in quibus, ut in illo Graeco, sic in hoc erant quaedam magis uenustae dulcesque sententiae quam aut necessariae aut interdum utiles; et erat oratio cum incitata et uibrans tum etiam accurata et polita. non probabantur haec senibus - saepe uidebam cum inridentem tum etiam irascentem et stomachantem Philippum — , sed mirabantur adulescentes, multitudo mouebatur. (327) Erat excellens iudicio uolgi et facile primas tenebat adulescens. etsi enim genus illud dicendi auctoritatis habebat parum, tamen aptum esse aetati uidebatur. et certe, quod et ingeni quaedam forma lucebat usu et exercitatione perfecta eratque uerborum astricta comprensio, summam hominum admirationem excitabat. sed cum iam honores et illa senior auctoritas grauius quiddam requireret, remanebat idem nec decebat idem; quodque exercitationem studiumque dimiserat, quod in eo fuerat acerrimum, concinnitas illa crebritasque sententiarum pristina manebat, sed ea uestitu illo orationis, quo consuerat, ornata non erat. hoc tibi ille, Brute, minus fortasse placuit quam placuisset, si illum flagrantem studio et florentem facultate audire potuisses. ambos os gêneros, era aclamado na juventude. De fato, por um lado, possuía aquele entusiasmo, típico de Ménecles, pela riqueza e elegância dos argumentos, entre os quais, tanto naquele grego como nele, eram às vezes mais elegantes e agradáveis do que muitas vezes eram ou necessários ou úteis; por outro lado, possuía um discurso não só impetuoso e agitado mas também acurado e polido. Isso não era louvado entre os mais velhos - frequentemente eu via Filipo não apenas zombando mas também encolerizando-se e irritando-se porém, os jovens admiravam-no, a multidão se comovia. [327] Era o melhor na opinião do vulgo e desde jovem com facilidade ocupava o primeiro lugar. De fato, embora aquele gênero oratório possuísse pouco prestígio, todavia parecia ser adequado à sua idade. E, sem dúvida, porque resplandecia um tipo de engenho aperfeiçoado pelo exercício e pelo uso bem como um preciso arranjo das palavras, suscitava a mais alta admiração dos homens. Mas quando os cargos públicos e a autoridade da maturidade exigiam algo mais respeitável, ele permanecia o mesmo e já não convinha ser o mesmo; e porque abandonara os exercícios e o entusiamo, que nele fora muito intenso, restava aquela simetria e a antiga fertilidade de argumentos, porém já não era, como de costume, ornamentada com aquele revestimento do discurso. Por isso, Bruto, talvez ele lhe agradou menos do que teria agradado, se você tivesse tido a oportunidade de ouvi-lo ardendo de entusiasmo e florescendo em 
[96] XCVI. (328) Tum Brutus: ego uero, inquit, et ista, quae dicis, uideo qualia sint et Hortensium magnum oratorem semper putaui maxumeque probaui pro Messalla dicentem, cum tu afuisti. Sic ferunt, inquam, idque declarat totidem quot dixit, ut aiunt, scripta uerbis oratio. ergo ille a Crasso consule et Scaeuola usque ad Paulum et Marcellum consules floruit, nos in eodem cursu fuimus a Sulla dictatore ad eosdem fere consules. sic Q. Hortensi uox exstincta fato suo est, nostra publico. Melius, quaeso, ominare, inquit Brutus. (329) Sit sane ut uis, inquam, et id non tam mea causa quam tua; sed fortunatus illius exitus, qui ea non uidit cum fierent, quae prouidit futura. saepe enim inter nos impendentis casus defleuimus, cum belli ciuilis causas in priuatorum cupiditatibus inclusas, pacis spem a publico consilio esse exclusam uideremus. sed illum uidetur felicitas ipsius, qua semper est usus, ab eis miseriis, quae consecutae sunt, morte uindicauisse. (330) Nos autem, Brute, quoniam post Hortensi clarissimi oratoris mortem orbae eloquentiae quasi tutores relicti sumus, domi teneamus eam saeptam liberali custodia, et hos ignotos atque impudentes procos repudiemus tueamurque ut adultam uirginem caste et ab amatorum impetu quantum possumus prohibea- seu talento.

[328] Então, Bruto disse: — Eu bem sei o significado do que você diz, bem como sempre considerei Hortênsio um grande orador e sobretudo pude apreciá-lo no disrcurso em defesa de Messala, quando você esteve ausente. - É o que afrmam, continuei, e o que demonstra seu discurso escrito que, como se diz, reproduz palavra por palavra o que foi pronunciado. Portanto, ele floresceu do consulado de Crasso e Cévola até quando eram cônsules Paulo e Marcelo, eu percorri a mesma carreira desde a ditadura de Sila até os mesmos cônsules. Assim, a voz de Quinto Hortênsio foi silenciada por sua própria morte, a minha pela da república. - Rogo que faças um melhor augúrio, disse Bruto. [329] — Seja como quiser, continuei, e isso não tanto por mim quanto por você, mas foi afortunado seu fim, que não viu a realização dos acontecimentos que foram previstos. De fato, muitas vezes, lastimamos entre nós as desgraças iminentes, quando víamos as motivações da guerra civil presentes em ambições privadas, e estava excluída a esperança de paz pela deliberação pública. Mas sua boa sorte, da qual sempre gozou, parece tê-lo livrado com a morte das desventuras que se sucederam. [330] Nós, porém, Bruto, já que depois da morte do ilustríssimo orador Hortênsio, permanecemos, por assim dizer, como tutores da eloquência órfã, guardemo-la no âmbito da casa, protegida por um confinamento digno de uma pessoa livre, e repudiemos esses pretendentes desonrados e impuden- 
mus. equidem etsi doleo me in uitam paulo serius tamquam in uiam ingressum, priusquam confectum iter sit, in hanc rei publicae noctem incidisse, tamen ea consolatione sustentor quam tu mihi, Brute, adhibuisti tuis suauissimis litteris, quibus me forti animo esse oportere censebas, quod ea gessissem, quae de me etiam me tacente ipsa loquerentur uiuerentque mortuo; quae, si recte esset, salute rei publicae, sin secus, interitu ipso testimonium meorum de re publica consiliorum darent.

[97] XCVII. (331) Sed in te intuens, Brute, doleo, cuius in adulescentiam per medias laudes quasi quadrigis uehentem transuersa incurrit misera fortuna rei publicae. hic me dolor tangit, haec me cura sollicitat et hunc mecum socium eiusdem et amoris et iudici. tibi fauemus, te tua frui uirtute cupimus, tibi optamus eam rem publicam in qua duorum generum amplissumorum renouare memoriam atque augere possis. Tuum enim forum, tuum erat illud curriculum, tu illuc ueneras unus, qui non linguam modo acuisses exercitatione dicendi, sed et ipsam eloquentiam locupletauisses grauiorum artium instrumento et isdem artibus decus omne uirtutis cum summa elo- tes, e cuidemos de sua castidade de mulher adulta, e a afastemos o quanto pudermos da avidez de seus amantes. Quanto a mim, contudo, lamento que, depois de iniciado um pouco tarde como que o caminho da vida, antes que o itinerário fosse completado, eu tenha caído nessa noite da república, todavia me sustenta aquela consolação, Bruto, que você me proporcionou em suas agradabilíssimas cartas, em que me aconselhava ser preciso manter o ânimo forte, pois aquilo que eu havia feito, mesmo que me calasse, por si só falaríam por mim e sobreviveríam à minha morte, feitos que, se se tomar o reto caminho da salvação da república, se, do contrário, da sua própria ruína, testemunharíam meus desígnios para a república.

[331] [331] Mas, olhando para você, Bruto, lamento que a infeliz sorte da república tenha sido obstáculo para sua juventude, como que uma quadriga em meio às glórias. Essa dor me aflige, essa preocupação me atormenta, e comigo está esse amigo no mesmo amor e no mesmo desígnio. Temos devoção por você, desejamos que você usufrua de sua virtude, esperamos que haja um república em que lhe seja possível reviver e promover a memória de duas ilustríssimas famílias. Era seu o fórum, sua aquela carreira, onde você veio a ser o único, que não apenas aperfeiçoou sua língua no exercício oratório, mas enriqueceu a própria eloquência com o aparato das artes mais eminentes e, com essas mesmas artes, uniu toda beleza da virtude com o grande mérito da eloquência. 
quentiae laude iunxisses. (332) Ex te duplex nos afficit sollicitudo, quod et ipse re publica careas et illa te. tu tamen, etsi cursum ingeni tui, Brute, premit haec importuna clades ciuitatis, contine te in tuis perennibus studiis et effice id quod iam propemodum uel plane potius effeceras, ut te eripias ex ea, quam ego congessi in hunc sermonem, turba patronorum. nec enim decet te ornatum uberrumis artibus, quas cum domo haurire non posses, arcessiuisti ex urbe ea, quae domus est semper habita doctrinae, numerari in uolgo patronorum. nam quid te exercuit Pammenes uir longe eloquentissimus Graeciae, quid illa uetus Academia atque eius heres Aristus hospes et familiaris meus, si quidem similes maioris partis oratorum futuri sumus? (333) Nonne cernimus uix singulis aetatibus binos oratores laudabilis constitisse? Galba fuit inter tot aequalis unus excellens, cui, quem ad modum accepimus, et Cato cedebat senior et qui temporibus illis aetate inferiores fuerunt; Lepidus postea, deinde Carbo; nam Gracchi in contionibus multo faciliore et liberiore genere dicendi, quorum tamen ipsorum ad aetatem laus eloquentiae perfecta nondum fuit; Antonius, Crassus, post Cotta, Sulpicius, Hortensius. nihil dico amplius, tantum dico: si mihi accidisset, ut numerarer in multis*** si operosa est concursatio magis op-
[332] Por causa de você uma dupla aflição nos atinge, que você tenha necessidade da república, e ela, de você. No entanto, embora o curso do seu engenho, Bruto, seja impedido por essa turbulenta calamidade da cidade, mantenha-se em seus permanentes estudos e realize aquilo que você em parte, ou melhor, plenamente, já realizou, que você se esquive dessa turba de patronos que eu amontoei nessa conversa. E, de fato, a você, bem dotado nas mais fecundas artes, das quais, embora não pudesse se embeber na pátria, importou o estudo daquela cidade que sempre foi tida como a morada do conhecimento, não convém ser enumerado na turba dos patronos. Ora, de que valeria você ter frequentado Pâmenes, o homem, de longe, mais eloquente da Grécia, de que valeria a velha academia e seu heredeiro e meu amigo Aristo, se, na verdade, seremos considerados semelhantes a maior parte dos oradores? [333] Não percebemos que com dificuldade se distinguiam em cada época dois oradores louváveis? Galba, entre tantos contemporâneos, foi o único a se destacar. Dele, conforme recebemos da tradição, estava não só Catão, mais velho, mas também aqueles que na época eram mais jovens; depois Lépido; em seguida Carbão; quanto aos Gracos, nas assembleias populares praticavam um gênero oratório muito mais fluente e mais espontânea; no entanto, no tempo deles a glória da eloquência ainda não havia amadurecido. Antônio, Crasso, depois Cota, Sulpício, Hortênsio. Não digo mais nada, só digo isso: se me tivesse ocor- 
portunorum*** rido ser enumerado entre muitos ${ }^{* * *}$ se é difícil a confusão*** 


\section{Bibliografia}

\section{- Edições do Brutus}

CICERO. Brutus (recognovit H. Malcovati). Leipzig, Teubner, 1965.

CICERO. Brutus (texte établi et traduit par Jules Martha). Paris, Les Belles Lettres, 1960.

CICERO. Brutus (Edited by A. E. Douglas). London, Oxford, 1966.

\section{- Estudos modernos}

BERTI, E. Scholasticorum Studia. Seneca il Vecchio e la cultura retorica e letteraria della prima età imperiale. Pisa-Roma. Giardini editori e stampatori in Pisa. 2007.

DESMOULIEZ, A.,

DOMINIK, W. J. (ed.), Roman Eloquence. Rhetorica in Society and Literature. London-New York, 1997.

DUGAN, J. Making a New Man: Ciceronian Self-Fashioning in the Rhetorical Works. Oxford, 2005.

DUPONT, F., "Recitatio and the reorganization of the Space of Public Discours", in The Roman Cultura Revolution, edited by T. Habinek and A. Schiesaro, Cambridge, 1997, pp. 44-59.

FAIRWEATHER, J., Seneca the Elder, Cambridge, 1981.

FOX, M. Cicero's Philosophy of History. Oxford, 2007.

GOWING, A. M., "Memory and Silence in Cicero's Brutus". In Eranos (2000), 98, $1 / 2$, pp. 39-64.

HENDRICKSON, G. L. "Literary Sources in Cicero's Brutus and the Technique of Citation in Dialogue" in American Journal of Philology 26, 1906 (a), pp. 184-199. HENDRICKSON, G. L. "The De Analogia of Julius Caesar; Its Occasion, Nature, and Date, with Additional Fragments". In: Classical Philology, Vol. 1, No. 2 (Apr., 1906), pp. 97-120. 
HENDRICKSON, G. L. "Cicero's Correspondence with Brutus and Calvus on Oratorical Style". In: The American Journal of Philology, Vol. 47, No. 3 (1926), pp. 234-258. http://www.jstor.org/stable/289689

HENDRICKSON, G. L. Brutus' De virtute

KEnNEDY, G. A. The Art of Rhetoric in the Roman World. Princeton: Princeton University Press, 1972.

LOWRIE, M. "Cicero on Caesar or Exemplum and Inability in the «Brutus»". In (eds. Alexander Arweiler, Melanie Moller) Vom Selbst-Verstandnis in Antike und Neuzeit. Notions of the Self in Antiquity and Beyond, Berlin-New York, 2008. pp. $131-54$.

MARCHESE, R. R. Bruto. Crocci editore. Roma, 2011.

NARDUCCI, E. "La storia dell'eloquenza romana nel Brutus", in Marco Tulio Cicerone, Bruto, introd., trad. e note di E. Narducci, Milano, 1995. pp. 5-86.

NARDUCCI, E. Cicerone e l'eloquenza romana. Retorica e progetto culturale. Roma-Bari, 1997.

NORDEN, E. La prosa d'arte antica (Tomo I) Roma, Salerno Editrice, 1986.

STEEL, C. E. "Cicero's Brutus: the End of Oratory and the Beginning of History?". In $B I C S, 46$, pp. 195-212.

STROUP, S. C. "Adulta virgo: The Personification of Textual Eloquence in Cicero's Brutus". In $M D, 50$ (2003), pp. 115-40.

SUMneR, G. V. The Orators in Cicero's Brutus: Prosopography and Chronology. Toronto, University of Toronto Press, 1972. 